Nevada

Environmental

Restoration

Project

Streamlined Approach for

Environmental Restoration Plan for

Corrective Action Unit 107:

Low Impact Soil Sites

Nevada Test Site, Nevada

Controlled Copy No.:

Revision: 1

March 2009

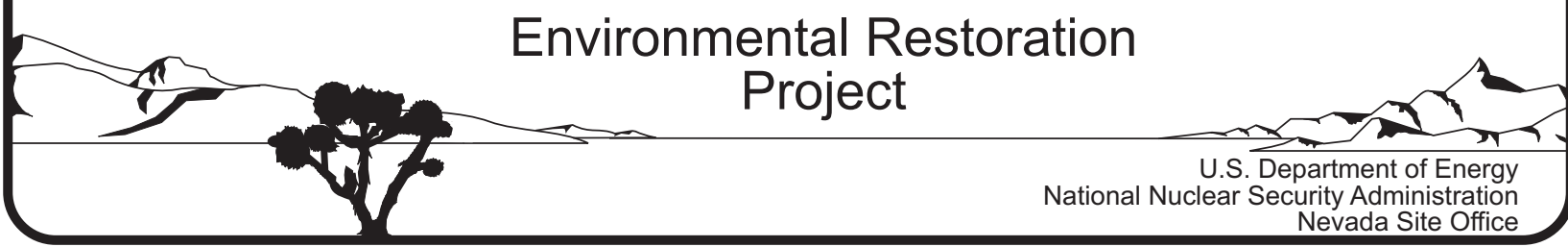




\section{DISCLAIMER}

Reference herein to any specific commercial product, process, or service by trade name, trademark, manufacturer, or otherwise, does not necessarily constitute or imply its endorsement, recommendation, or favoring by the U.S. Government or any agency thereof.

This report has been reproduced directly from the best available copy.

Available for sale to the public from:

U.S. Department of Commerce

National Technical Information Service

5285 Port Royal Road

Springfield, VA 22161-0002

Telephone: (800) 553-6847

Fax: (703) 605-6900

E-mail: orders@ntis.gov

Online ordering: http://www.ntis.gov/ordering.htm

Available electronically at http://www.osti.gov/bridge.

Available for a processing fee to the U.S. Department of Energy and its contractors, in paper, from:

U.S. Department of Energy

Office of Scientific and Technical Information

P.O. Box 62

Oak Ridge, TN 37831-0062

Telephone: (865) 576-8401

Fax: (865) 576-5728

E-mail: reports@adonis.osti.gov 


\title{
STREAMLINED APPROACH FOR ENVIRONMENTAL RESTORATION PLAN FOR CORRECTIVE ACTION UNIT 107: LOW IMPACT SOIL SITES NEVADA TEST SITE, NEVADA
}

\author{
U.S. Department of Energy \\ National Nuclear Security Administration \\ Nevada Site Office
}

Controlled Copy No.:

Revision: 1

March 2009 
THIS PAGE INTENTIONALLY LEFT BLANK 


\section{STREAMLINED APPROACH FOR ENVIRONMENTAL RESTORATION PLAN FOR CORRECTIVE ACTION UNIT 107: LOW IMPACT SOIL SITES NEVADA TEST SITE, NEVADA}

Approved By: Original signed by: K Cabble

Kevin J. Cabble

Acting Soils Federal Sub-Project Director

Environmental Restoration Project,

Approved By:

Robert F. Boéhlecke

Federal Project Director

Environmental Restoration Project
Date: $3-23 \cdot 09$

Date: $3 / 23 / 09$ 
THIS PAGE INTENTIONALLY LEFT BLANK 


\section{TABLE OF CONTENTS}

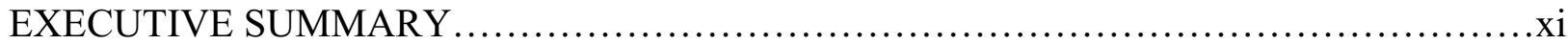

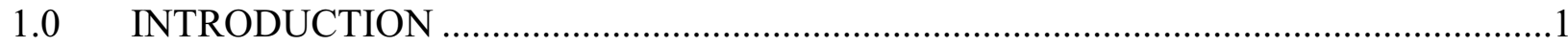

$1.1 \quad$ SAFER PROCESS ........................................................................................

1.2 SUMMARY OF PROPOSED CORRECTIVE ACTIONS .......................................................2

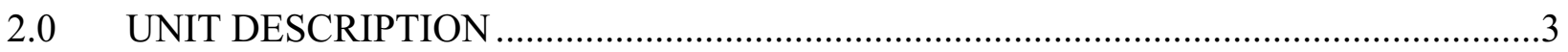

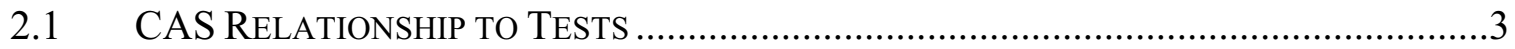

2.1.1 CASs Resulting From Deep Underground Detonations ................................

2.1.2 CASs Resulting From Far Above the Ground Detonations...........................

2.1.3 CAS Resulting From Near the Ground Surface Detonation .........................5

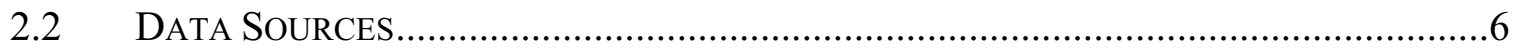

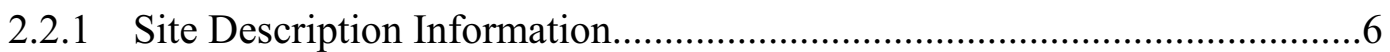

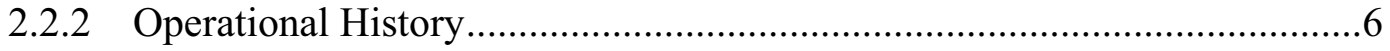

2.2.3 Release Information ........................................................................

2.2.3.1 Radiological Effluents Released from U.S. Continental Tests,

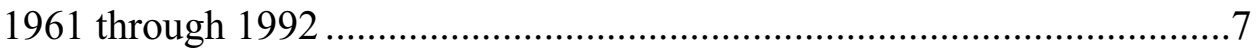

2.2.3.2 Radiological Safety and Health Reports ......................................

2.2.4 Historical Characterization Information ..................................................

2.2.4.1 Aerial Radiological Surveys (Fly-Over Data) …........................10

2.2.4.2 Nevada Test Site Contaminated Land Areas Report ...................11

2.2.4.3 Radionuclide Inventory and Distribution Program......................12

2.3 CAS 01-23-02, ATMOSPHERIC TEST SITE - HIGH ALT ..............................................14

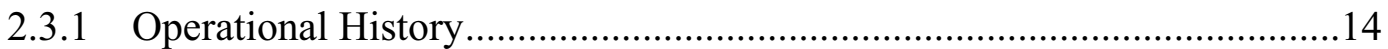

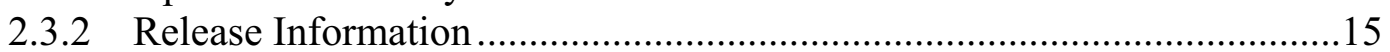

2.3.3 Historical Characterization Information ..................................................16

2.3.3.1 Fly-Over Data ........................................................................ 16

2.3.3.2 Contaminated Land Report Data ...............................................17

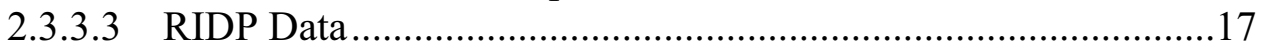

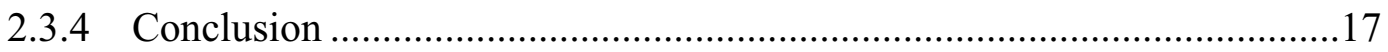

2.4 CAS 02-23-02, ConTAMINATED AREAS (2) ....................................................19

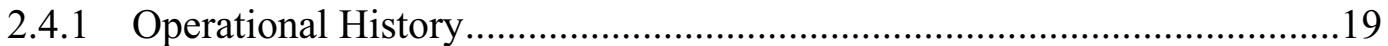

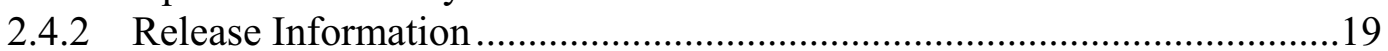

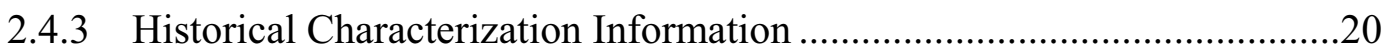

2.4.3.1 Fly-Over Data …………………………….........................20

2.4.3.2 Contaminated Land Report Data ……………..........................21

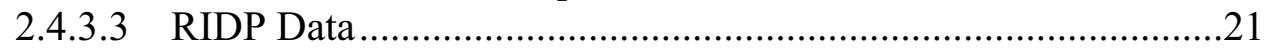

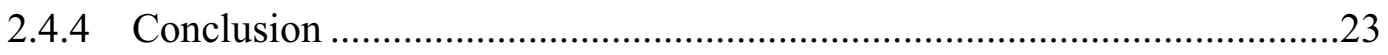

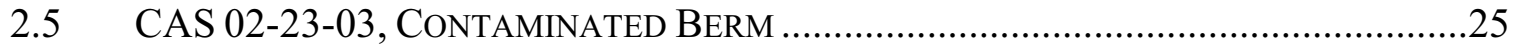

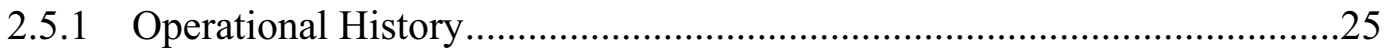

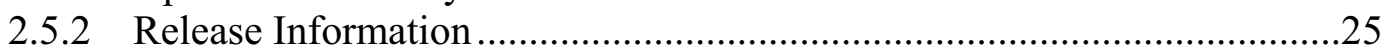

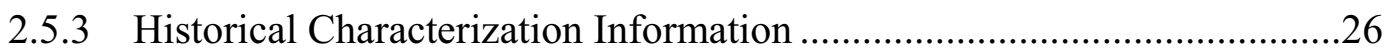

2.5.3.1 Fly-Over Data …………………………….......................26

2.5.3.2 Contaminated Land Report Data ………………......................27

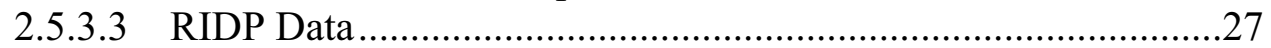




\section{TABLE OF CONTENTS (continued)}

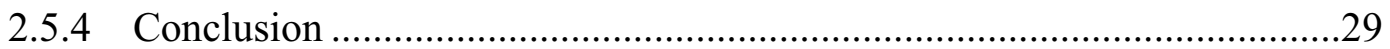

2.6 CAS 02-23-10, GOURD-AMBER CONTAMINATION AREA …………………............31

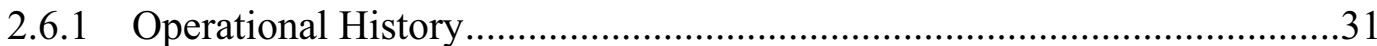

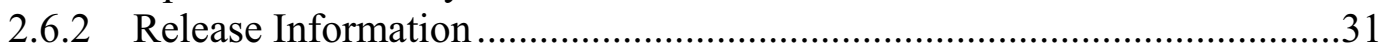

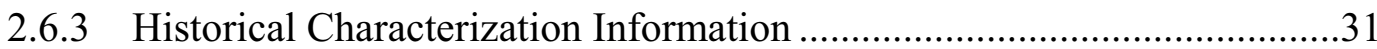

2.6.3.1 Fly-Over Data .......................................................................

2.6.3.2 Contaminated Land Report Data ……………............................32

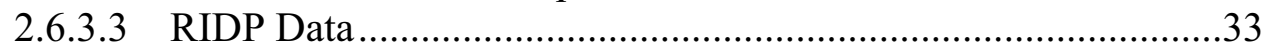

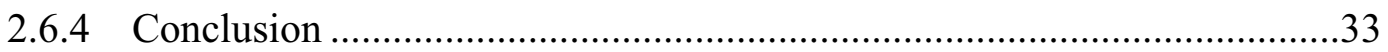

2.7 CAS 02-23-11, SAPPHO CONTAMINATION AREA.....................................................37

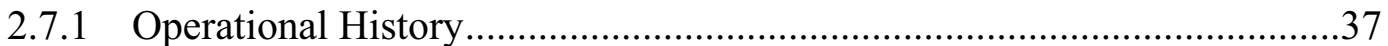

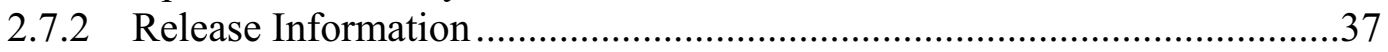

2.7.3 Historical Characterization Information ....................................................37

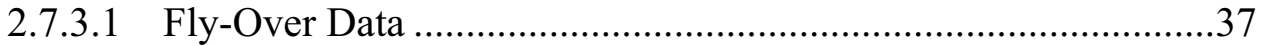

2.7.3.2 Contaminated Land Report Data …………….............................38

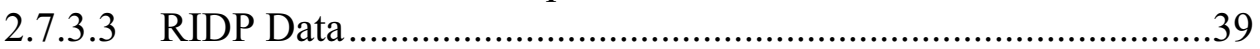

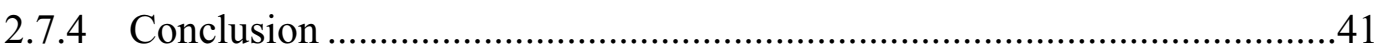

2.8 CAS 02-23-12, SCUTTLE CONTAMINATION AREA ................................................43

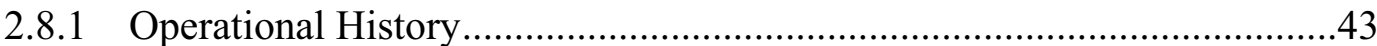

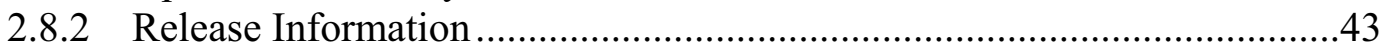

2.8.3 Historical Characterization Information ................................................43

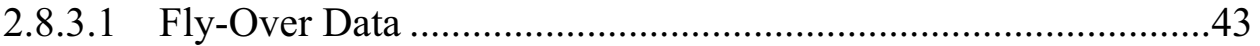

2.8.3.2 Contaminated Land Report Data ……………............................45

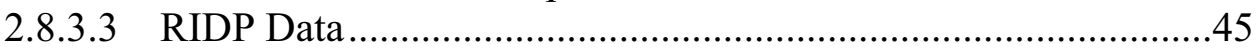

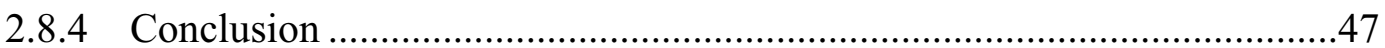

2.9 CAS 03-23-24, SEAWEEd B ConTAMINATION AREA ……………………............49

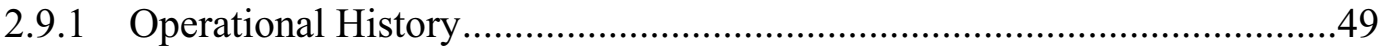

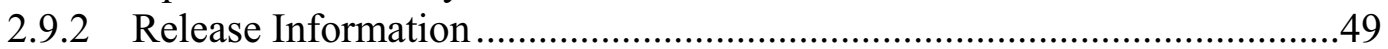

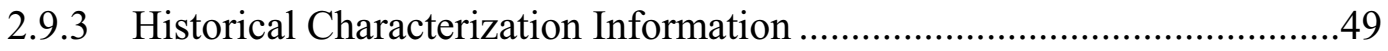

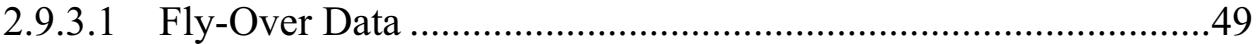

2.9.3.2 Contaminated Land Report Data ................................................50

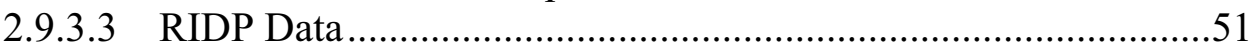

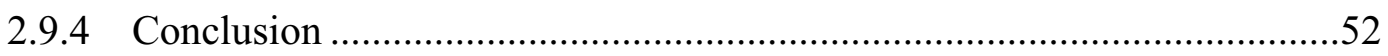

2.10 CAS 03-23-27, ADZE CONTAMINATION AREA …….............................................54

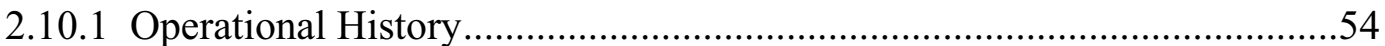

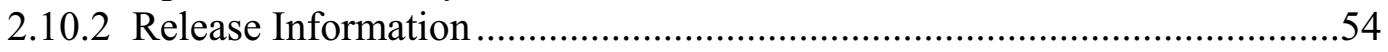

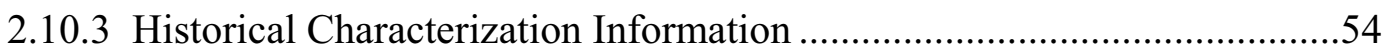

2.10.3.1 Fly-Over Data ......................................................................54

2.10.3.2 Contaminated Land Report Data ……………….......................55

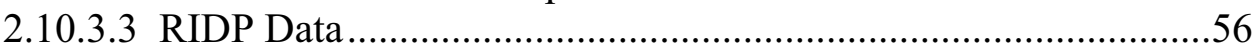

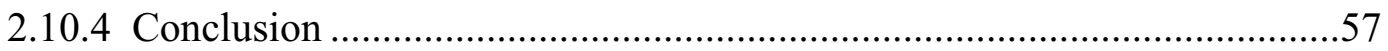

2.11 CAS 03-23-28, MANZANAS CONTAMINATION AREA...............................................59

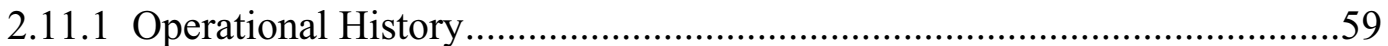




\section{TABLE OF CONTENTS (continued)}

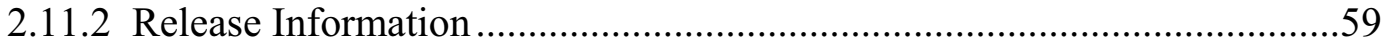

2.11.3 Historical Characterization Information ...............................................59

2.11.3.1 Fly-Over Data ..................................................................59

2.11.3.2 Contaminated Land Report Data .........................................60

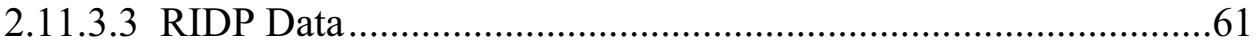

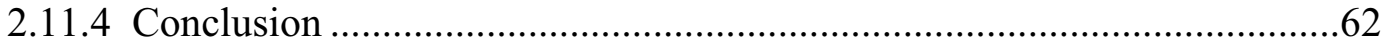

2.12 CAS 03-23-29, Truchas-Chamisal ContAminAtion AREA ..............................64

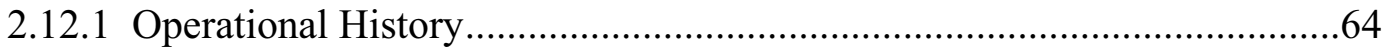

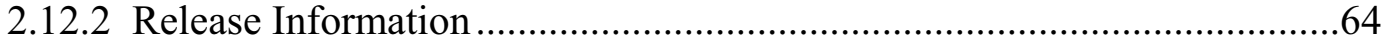

2.12.3 Historical Characterization Information ................................................64

2.12.3.1 Fly-Over Data ...................................................................6. 65

2.12.3.2 Contaminated Land Report Data .........................................66

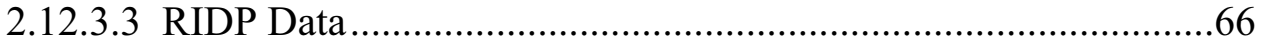

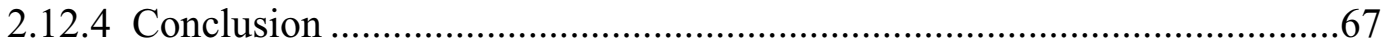

2.13 CAS 04-23-02, ATMOSPHERIC TEST Site T4-A ................................................69

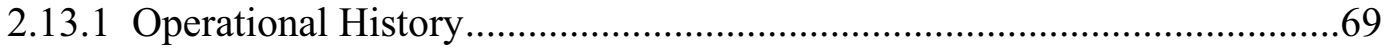

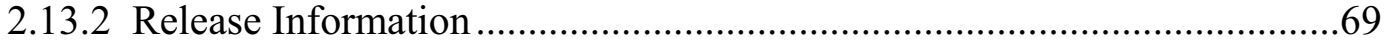

2.13.3 Historical Characterization Information ...............................................69

2.13.3.1 Fly-Over Data ....................................................................69

2.13.3.2 Contaminated Land Report Data ........................................70

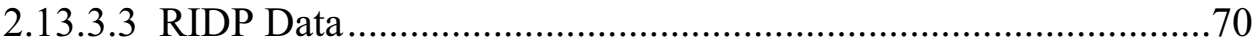

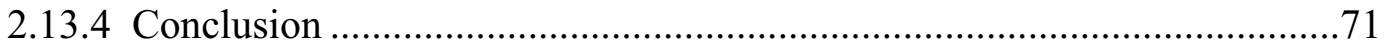

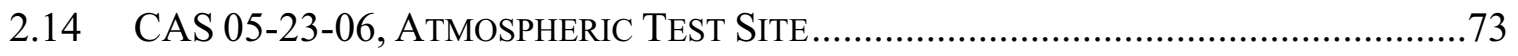

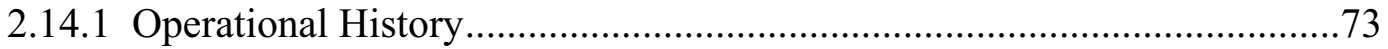

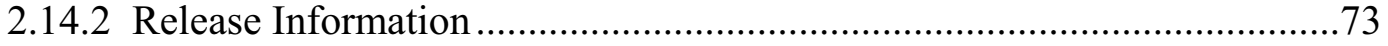

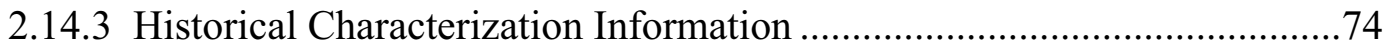

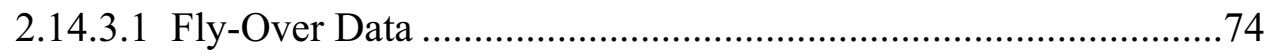

2.14.3.2 Contaminated Land Report Data ........................................75

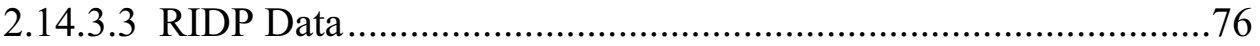

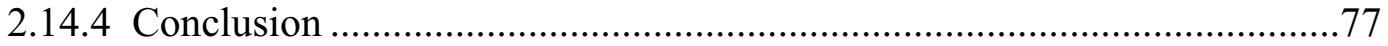

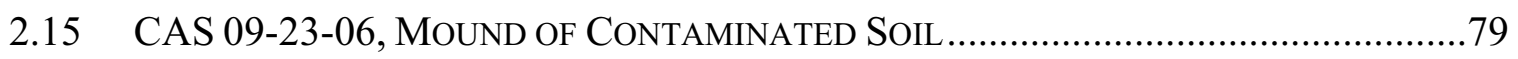

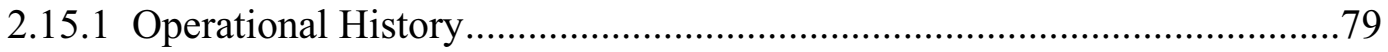

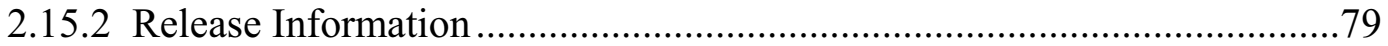

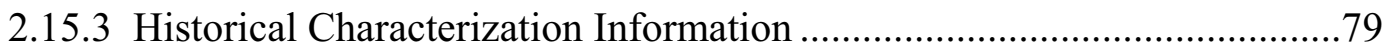

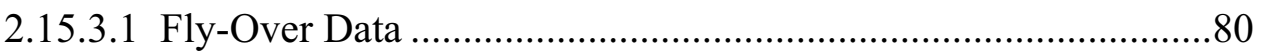

2.15.3.2 Contaminated Land Report Data .......................................81

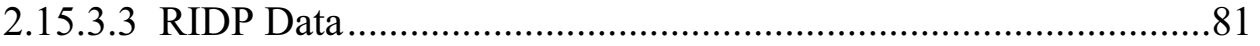

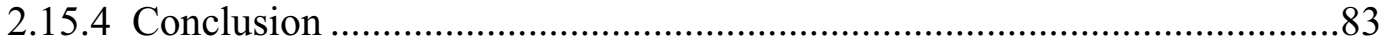

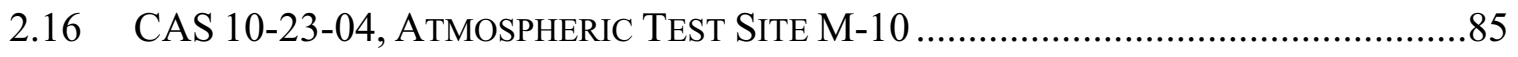

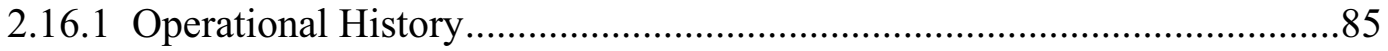

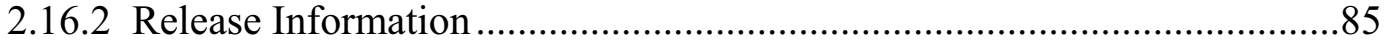

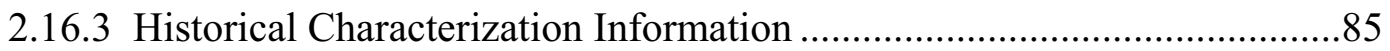

2.16.3.1 Fly-Over Data ....................................................................8 86

2.16.3.2 Contaminated Land Report Data .......................................86

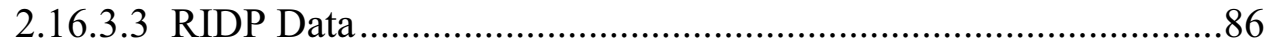




\section{TABLE OF CONTENTS (continued)}

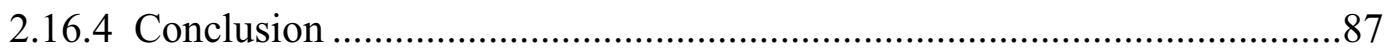

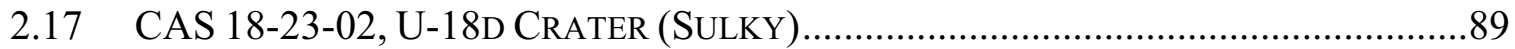

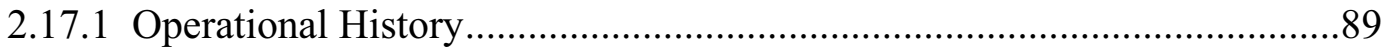

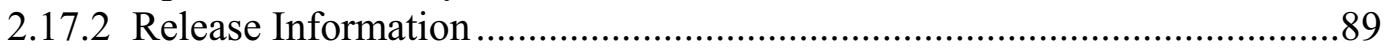

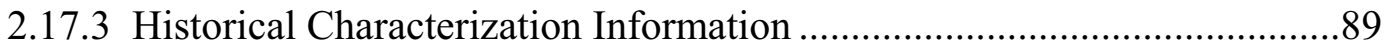

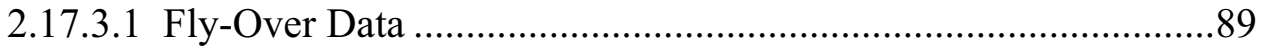

2.17.3.2 Contaminated Land Report Data ..............................................90

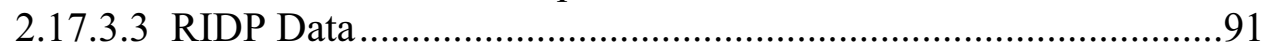

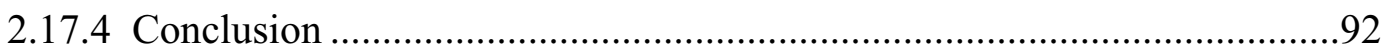

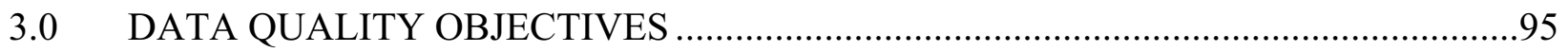

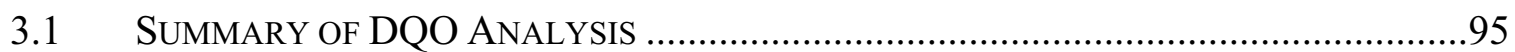

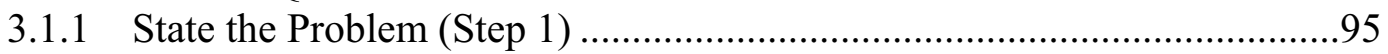

3.1.1.1 Problem Statement .................................................................95

3.1.1.2 Conceptual Site Model...............................................................95

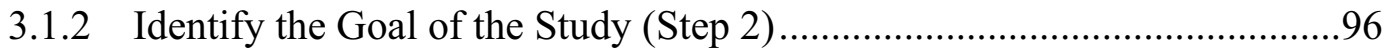

3.1.3 Identify Information Inputs (Step 3) ……………...................................96

3.1.3.1 Information Needs .................................................................96

3.1.3.2 Sources of Information ............................................................96

3.1.4 Define the Boundaries of the Study (Step 4) ...........................................97

3.1.4.1 Population of Interest............................................................97

3.1.4.2 Time Constraints.....................................................................98

3.1.5 Develop the Analytic Approach (Step 5) …………................................98

3.1.5.1 Decision Rules ...................................................................98

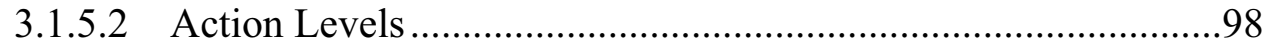

3.1.5.3 Measurement and Analysis Sensitivity ...................................100

3.1.6 Specify Performance or Acceptance Criteria (Step 6) …………...............100

3.1.6.1 Decision Errors .....................................................................100

3.1.7 Develop the Plan for Obtaining Data (Step 7) .........................................101

3.1.7.1 Process Knowledge ..............................................................101

3.1.7.2 Aerial Survey Data...................................................................101

3.1.7.3 Contaminated Lands Survey Data ...........................................101

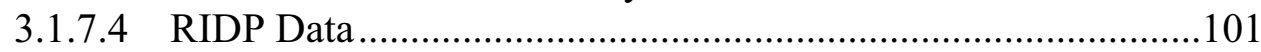

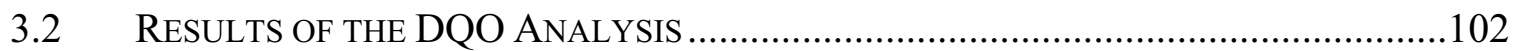

3.2.1 Action Level Determination and Basis ...............................................102

3.2.2 Hypothesis Test............................................................................102

3.2.3 Statistical Model ..............................................................................102

3.2.4 Design Description/Option .................................................................102

3.2.5 Conceptual Site Model.......................................................................105

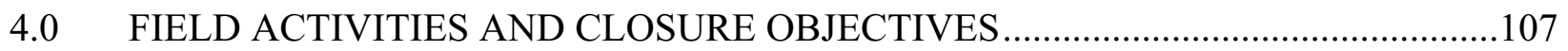

4.1 CONTAMINANTS OF POTENTIAL CONCERN.......................................................107

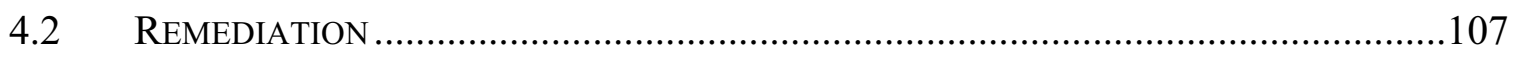

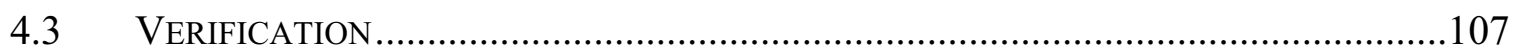




\section{TABLE OF CONTENTS (continued)}

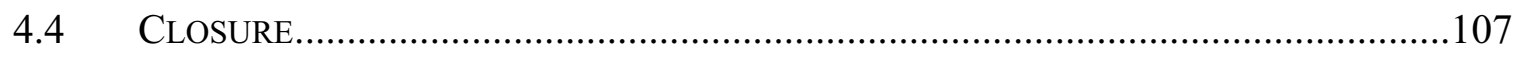

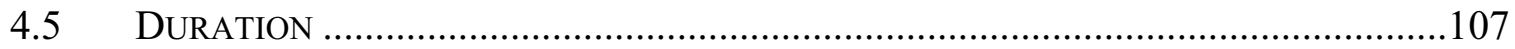

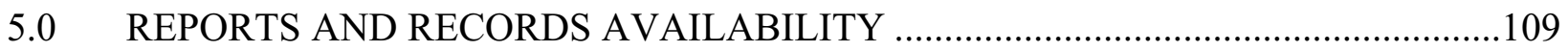

6.0 INVESTIGATION/REMEDIATION WASTE MANAGEMENT ..................................111

7.0 QUALITY ASSURANCE/QUALITY CONTROL ……………................................113

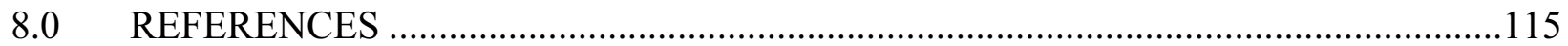

LIBRARY DISTRIBUTION LIST

\section{LIST OF FIGURES}

Figure 1. Corrective Action Unit 107 Site Location Map ..............................................

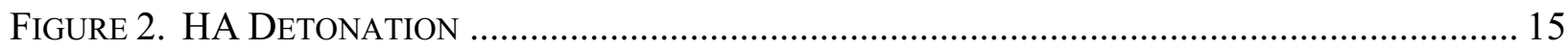

FiguRE 3. CAS 01-23-02 VicinITY WITH SELECTEd RIDP IN SITU MEASUREMENTS ..................... 18

Figure 4. CAS 02-23-02 Vicinity With SELECTEd RIDP In Situ MEASUREMENTS ..................... 24

FiguRE 5. CAS 02-23-03 Vicinity With SELECTEd RIDP In SITU MEASUREMENTS ........................ 30

Figure 6. CAS 02-23-10 VicinITY WITH SELECTEd RIDP IN SITU MEASUREMENTS ...................... 34

Figure 7. CAU 107 CASs with Contamination Attributable to Nearby Detonations .. 35

FiguRE 8. CAS 02-23-11 Vicinity with SELECTEd RIDP IN SITU MEASUREMENTS ..................... 42

FigURE 9. CAS 02-23-12 Vicinity WITH SELECTED RIDP IN SITU MEASUREMENTS ...................... 48

Figure 10. CAS 03-23-24 Vicinity WITH SElECted RIDP IN SITU MEASUREMENTS ................... 53

Figure 11. CAS 03-23-27 Vicinity with Selected RIDP In Situ MEASUREMENTS ................... 58

FigURE 12. CAS 03-23-28 VicINITY WITH SELECTED RIDP IN SITU MEASUREMENTS ..................... 63

Figure 13. CAS 03-23-29 Vicinity with SElected RIDP In SITU MEASUREMENTS ....................... 68

FigURE 14. CAS 04-23-02 ViCINITY WITH SELECTED RIDP IN SITU MEASUREMENTS ................... 72

FigURE 15. CAS 05-23-06 VicINITY WITH SELECTED RIDP IN SITU MEASUREMENTS ................... 78

FiguRE 16. CAS 09-23-06 Vicinity with SELECTEd RIDP IN SITU MEASUREMENTS ................... 84

FiguRE 17. CAS 10-23-04 Vicinity With SELECTED RIDP In SITU MEASUREMENTS ................... 88

Figure 18. CAS 18-23-02 VicinItY with SElected RIDP In SITU MEASUREMENTS .................. 93

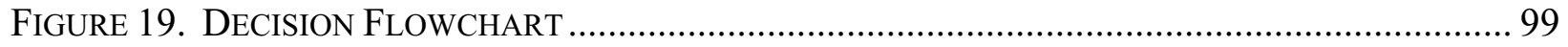

\section{LIST OF TABLES}

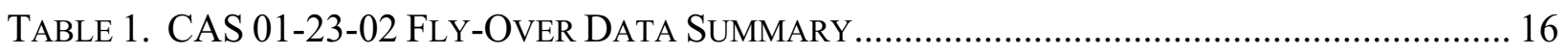

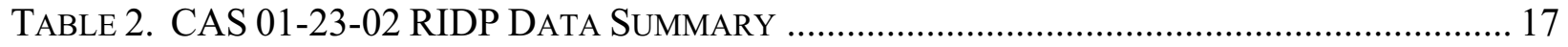

TABLE 3. CAS 02-23-02 Fly-Over DATA SUMMARY …………................................................... 20

Table 4. CAS 02-23-02 Contaminated Land SuRvey Data Summary.................................. 21

Table 5. SuRface Contamination Release Values In DPM/100 CMㄹ .................................. 22

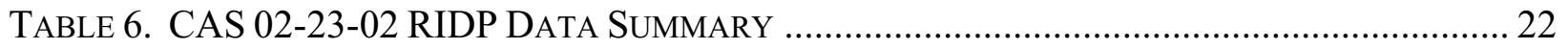




\section{TABLE OF CONTENTS (continued)}

TABLE 7. CAS 02-23-03 Fly-OVER DATA SuMMARY ......................................................... 26

TABLE 8. CAS 02-23-03 CONTAMINATED LAND SuRVEY DATA SUMMARY.............................. 27

TABle 9. Surface CONTAMINATION RELEASE VALUES IN DPM/100 $\mathrm{CM}^{2}$................................. 28

TABLE 10. CAS 02-23-03 RIDP DATA SUMMARY ….......................................................... 28

TABLE 11. CAS 02-23-10 Fly-OVER DATA SUMMARY......................................................... 32

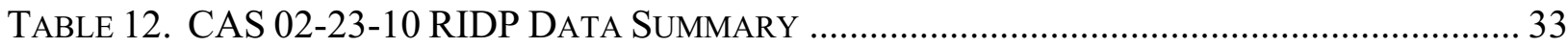

TABLE 13. CAS 02-23-11 FLY-Over DATA SUMMARY........................................................ 38

TABLE 14. CAS 02-23-11 CONTAMINATED LAND SURVEY DATA SUMMARY.............................. 39

TABle 15. Surface CONTAMINATION RELEASE VALUES IN DPM/100 $\mathrm{CM}^{2}$................................ 40

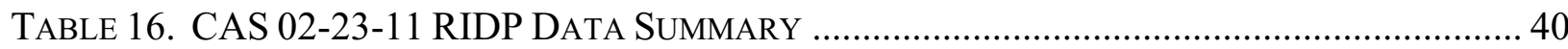

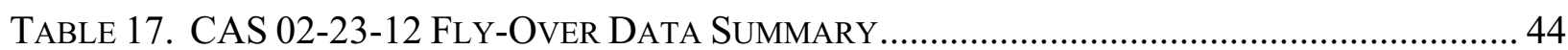

TABLE 18. CAS 02-23-12 CONTAMINATED LAND SURVEY DATA SUMMARY............................. 45

TABLE 19. Surface CONTAMINATION RELEASE VALUES IN DPM/100 CM ${ }^{2}$.............................. 45

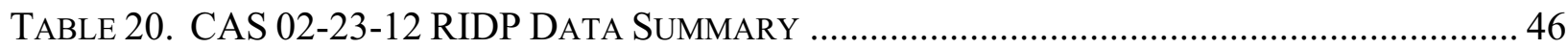

TABLE 21. CAS 03-23-24 Fly-OVER DATA SUMMARY ......................................................... 50

TABLE 22. CAS 03-23-24 CONTAMINATED LAND SuRVEy DATA SuMMARY............................ 51

TABlE 23. Surface CONTAMINATION RELEASE VALUES IN DPM/100 $\mathrm{CM}^{2}$.............................. 51

TABLE 24. CAS 03-23-27 FLY-OVER DATA SUMMARY ........................................................ 55

TABLE 25. CAS 03-23-27 CONTAMINATED LAND SURVEY DATA SUMMARY............................. 55

TABle 26. Surface CONTAMINATION RELEASE VALUES IN DPM/100 $\mathrm{CM}^{2}$................................ 56

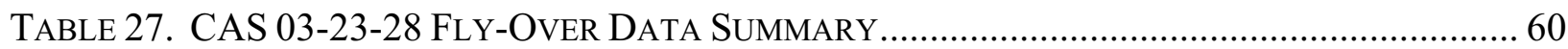

TABLE 28. CAS 03-23-28 CONTAMINATED LAND SURVEY DATA SUMMARY.............................. 60

TABle 29. Surface CONTAMINATION RELEASE VALUES IN DPM/100 $\mathrm{CM}^{2}$.............................. 61

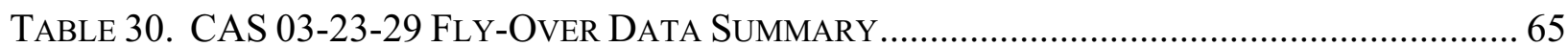

TABLE 31. CAS 03-23-29 CONTAMINATED LAND SURVEY DATA SUMMARY.............................66

TABlE 32. Surface CONTAMINATION RELEASE VALUES IN DPM/100 $\mathrm{CM}^{2}$.............................66 66

TABLE 33. CAS 04-23-02 Fly-OVER DATA SUMMARY.......................................................... 70

TABLE 34. CAS 04-23-02 RIDP DATA SUMMARY …........................................................... 71

TABLE 35. CAS 05-23-06 FLY-OVER DATA SUMMARY.......................................................... 74

TABLE 36. CAS 05-23-06 CONTAMINATED LAND SURVEY DATA SUMMARY............................. 75

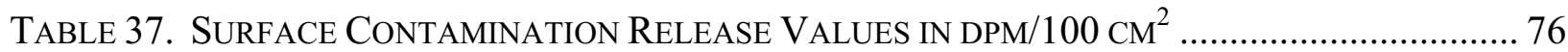

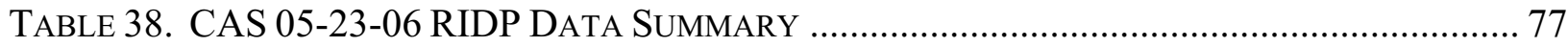

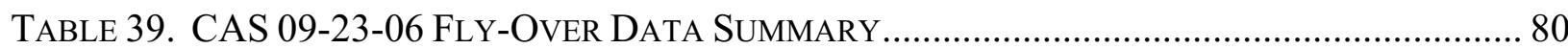

TABLE 40. CAS 09-23-06 CONTAMINATED LAND SURVEY DATA SUMMARY............................. 81

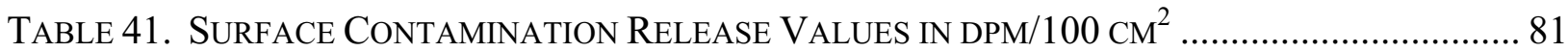

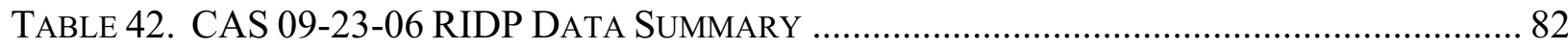




\section{TABLE OF CONTENTS (continued)}

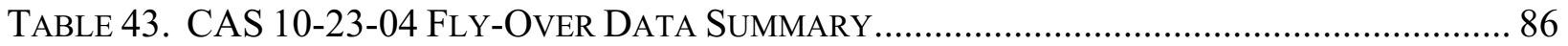

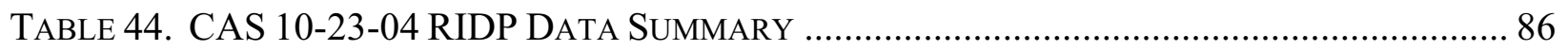

TABLE 45. CAS 18-23-02 Fly-OvER DATA SUMMARY ......................................................... 90

TABLE 46. CAS 18-23-02 CONTAMINATED LAND SURVEY DATA SUMMARY............................. 91

TABLE 47. Surface CONTAMINATION RELEASE VALUES IN DPM/100 CM ${ }^{2}$.............................. 91

TABLE 48. SUMMARY OF DQO ANALYSIS .......................................................................... 103

\section{APPENDICES}

ApPEndiX A. Project Organization

Appendix B. NeVAda Division of ENVIRonMental Protection COMMENT Response Form 
CAU 107 SAFER Plan

Section: Table of Contents

Revision: 1

Date: March 2009

THIS PAGE INTENTIONALLY LEFT BLANK 


\section{ACRONYMS AND ABBREVIATIONS}

\begin{tabular}{|c|c|}
\hline AEC & U.S. Atomic Energy Commission \\
\hline amsl & above mean sea level \\
\hline $\mathrm{BN}$ & Bechtel Nevada \\
\hline CAIP & Corrective Action Investigation Plan \\
\hline CAS & Corrective Action Site \\
\hline CAU & Corrective Action Unit \\
\hline CFR & Code of Federal Regulations \\
\hline $\mathrm{cm}^{2}$ & square centimeter(s) \\
\hline cps & counts per second \\
\hline CSM & conceptual site model \\
\hline DCG & Derived Concentration Guide \\
\hline DNA & Defense Nuclear Agency \\
\hline DoD & U.S. Department of Defense \\
\hline DOE & U.S. Department of Energy \\
\hline $\mathrm{DOE} / \mathrm{NV}$ & U.S. Department of Energy, Nevada Operations Office \\
\hline dpm & disintegration(s) per minute \\
\hline DQO & data quality objective \\
\hline DRI & Desert Research Institute \\
\hline DTRA & Defense Threat Reduction Agency \\
\hline DU & depleted uranium \\
\hline EPA & U.S. Environmental Protection Agency \\
\hline FIDLER & Field Instrument for the Detection of Low-Energy Radiation \\
\hline FFACO & Federal Facility Agreement and Consent Order \\
\hline $\mathrm{ft}$ & foot (feet) \\
\hline $\mathrm{ft}^{2}$ & square foot (feet) \\
\hline HA & HIGH ALTITUDE \\
\hline $\mathrm{kt}$ & kiloton(s) \\
\hline LLNL & Lawrence Livermore National Laboratory \\
\hline $\mathrm{m}$ & meter(s) \\
\hline $\mathrm{M \& OC}$ & Management and Operations Contractor \\
\hline $\mathrm{microR} / \mathrm{hr}$ & microroentgens per hour \\
\hline $\mathrm{mrem} / \mathrm{yr}$ & millirem(s) per year \\
\hline
\end{tabular}




\section{ACRONYMS AND ABBREVIATIONS (continued)}

$\mathrm{mR} / \mathrm{hr} \quad$ milliroentgen(s) per hour

$\mathrm{nCi} / \mathrm{m}^{2} \quad$ nanocurie(s) per square meter

NCRP National Council on Radiation Protection

NNSA/NSO U.S. Department of Energy, National Nuclear Security Administration Nevada Site Office

NNSA/NV U.S. Department of Energy, National Nuclear Security Administration Nevada Operations Office

NSTec National Security Technologies, LLC

NTS Nevada Test Site

QA quality assurance

QC quality control

$\mathrm{R} / \mathrm{hr} \quad$ roentgen(s) per hour

RadCon Radiological Control

REECo Reynolds Electrical and Engineering Company, Inc.

RIDP Radionuclide Inventory and Distribution Program

RMA Radioactive Material Area

ROI region of interest

RSL Remote Sensing Laboratory

RSN Raytheon Services Nevada

SAFER Streamlined Approach for Environmental Restoration

UGTA Underground Test Area

UR use restriction

URMA Underground Radioactive Material Area 


\section{EXECUTIVE SUMMARY}

This Streamlined Approach for Environmental Restoration Plan covers activities associated with Corrective Action Unit (CAU) 107 of the Federal Facility Agreement and Consent Order (1996 [as amended February 2008]). CAU 107 consists of the following Corrective Action Sites (CASs) located in Areas 1, 2, 3, 4, 5, 9, 10, and 18 of the Nevada Test Site.

- CAS 01-23-02, Atmospheric Test Site - High Alt

- CAS 02-23-02, Contaminated Areas (2)

- CAS 02-23-03, Contaminated Berm

- CAS 02-23-10, Gourd-Amber Contamination Area

- CAS 02-23-11, Sappho Contamination Area

- CAS 02-23-12, Scuttle Contamination Area

- CAS 03-23-24, Seaweed B Contamination Area

- CAS 03-23-27, Adze Contamination Area

- CAS 03-23-28, Manzanas Contamination Area

- CAS 03-23-29, Truchas-Chamisal Contamination Area

- CAS 04-23-02, Atmospheric Test Site T4-a

- CAS 05-23-06, Atmospheric Test Site

- CAS 09-23-06, Mound of Contaminated Soil

- CAS 10-23-04, Atmospheric Test Site M-10

- CAS 18-23-02, U-18d Crater (Sulky)

Based on historical documentation, personnel interviews, site process knowledge, site visits, photographs, engineering drawings, field screening, analytical results, and the results of data quality objectives process (Section 3.0), closure in place with administrative controls or no further action will be implemented for CAU 107.

CAU 107 closure activities will consist of implementing use restrictions (URs) at two sites, CAS 03-23-29 and CAS 18-23-02. Of the 15 sites, 13 do not require URs. 
CAU 107 SAFER Plan

Section: Executive Summary

Revision: 1

Date: March 2009

THIS PAGE INTENTIONALLY LEFT BLANK 


\subsection{INTRODUCTION}

This Streamlined Approach for Environmental Restoration (SAFER) Plan identifies the activities required for the closure of Corrective Action Unit (CAU) 107. CAU 107 is included in the Federal Facility Agreement and Consent Order (FFACO, 1996 [as amended February 2008]), and consists of the following Corrective Action Sites (CASs):

- CAS 01-23-02, Atmospheric Test Site - High Alt

- CAS 02-23-02, Contaminated Areas (2)

- CAS 02-23-03, Contaminated Berm

- CAS 02-23-10, Gourd-Amber Contamination Area

- CAS 02-23-11, Sappho Contamination Area

- CAS 02-23-12, Scuttle Contamination Area

- CAS 03-23-24, Seaweed B Contamination Area

- CAS 03-23-27, Adze Contamination Area

- CAS 03-23-28, Manzanas Contamination Area

- CAS 03-23-29, Truchas-Chamisal Contamination Area

- CAS 04-23-02, Atmospheric Test Site T4-a

- CAS 05-23-06, Atmospheric Test Site

- CAS 09-23-06, Mound of Contaminated Soil

- CAS 10-23-04, Atmospheric Test Site M-10

- CAS 18-23-02, U-18d Crater (Sulky)

\subsection{SAFER PROCESS}

CAUs that may be closed using the SAFER process have conceptual corrective actions that are clearly identified. The SAFER process combines elements of the data quality objective (DQO) process and the observational approach to plan and conduct closure activities. The DQOs are used to identify the problem and define the type and quality of data needed to complete the investigation phase of the SAFER process. The purpose of the investigation phase is to verify the adequacy of existing information used to determine the chosen corrective action. The observational approach provides a framework for managing uncertainty during the planning and decision-making phases of the project. The DQOs for CAU 107 are described in Section 3.0.

The SAFER process allows for technical decisions to be made based on information gathered during site visits, interviews, meetings, research, and a consensus of opinion by the CAU 107 team members. Any uncertainties are addressed by documented assumptions that are verified by historical documentation, photographs, engineering drawings, field screening, analytical results, and onsite observations. 
Historical documentation and existing characterization data were reviewed to develop this SAFER Plan. There is sufficient information to close CAU 107 using the SAFER process without the collection of additional data. The existing data support the selection of a closure option of closure in place with administrative controls for some CASs and no further action for others.

\subsection{Summary of Proposed Corrective Actions}

CAU 107 closure activities will consist of implementing use restrictions (URs) at two sites, CAS 03-23-29 and CAS 18-23-02. UR warning signs will be posted at these two sites. Of the 15 sites, 13 do not require URs. The URs are a conservative measure, implemented due to the assumption that limited surface contamination is present and additional characterization is not feasible. URs are not required to achieve FFACO closure at the remaining sites; however, an additional control is in place through requirements set forth in Title 10 Code of Federal Regulations (CFR) Part 835, “Occupational Radiation Protection” (CFR, 1993). 


\subsection{UNIT DESCRIPTION}

CAU 107, which includes 15 CASs in Areas 1, 2, 3, 4, 5, 9, 10, and 18 of the Nevada Test Site (NTS), is under the Soils Sub-Project of the U.S. Department of Energy, National Nuclear Security Administration Nevada Site Office (NNSA/NSO) Environmental Restoration Project (Figure 1).

The CASs include areas where nuclear weapons tests were conducted. Nuclear weapons tests were often conducted as part of a series, and each series was given a name such as Operation Mandrel. Individual tests within a series were given names, such as CALABASH. Nuclear weapons tests can release gaseous and/or non-gaseous radioactivity into the environment. Radioactive gases produced by nuclear weapons testing include isotopes of xenon, krypton, and iodine. Non-gaseous radionuclides resulting from nuclear weapons testing include cobalt-60, cesium-137, strontium-90, uranium isotopes, plutonium isotopes, and europium isotopes.

\subsection{CAS Relationship TO TeSTS}

Historical information on the nuclear weapons testing that resulted in the CAU 107 CASs shows that a distinct, test-related release of radionuclides to the surface soils that could lead to a worker dose greater than 25 millirem per year (mrem/yr) does not appear to have occurred at or near the CAS locations. The conceptual site model (CSM) is based on process knowledge and historical data that indicate that radiological contamination, if present, resulted from the surface deposition of radionuclides. The CASs were evaluated to determine whether there was a release to the surface with the potential to cause a worker dose greater than $25 \mathrm{mrem} / \mathrm{yr}$. The radiological dose at the surface does not depend on the depth of contamination; therefore, surface soils was not defined. The CASs resulted from nuclear weapons testing and associated activities, which fall into three categories developed for this SAFER Plan: deep underground, far above the ground surface, or near the ground surface. Each category is discussed below.

\subsubsection{CASS RESULTING FroM DEEP UNDERGROUND DETONATIONS}

Eleven of the CASs in CAU 107 resulted from underground nuclear weapons detonations. These specific underground detonations were conducted in shafts drilled deep into the ground and often left visible evidence on the surface in the form of subsidence craters, which are depressions on the surface from the roof of the blast cavity collapsing into the void left by the explosion. Some underground detonations did not form craters but still have the potential to collapse. These areas are designated as potential craters. Entry into craters or potential craters is not permitted unless a subsidence study is conducted to ensure the area is safe for entry. Subsidence studies have not been completed for any of the crater or potential crater areas associated with the CASs in this SAFER Plan because no sampling or entry is required.

Most underground tests were designed to contain radiological releases so that radioactive materials would be held deep underground and not allowed to escape to the atmosphere. The containment methods were generally successful; however, radioactive gases did escape from some underground tests. Radioactive gases disperse in air quickly and have short half-lives (Nuclear Data Center, 2006). Therefore, even for tests for which there was a containment failure, the surface soils in the area generally did not become radiologically contaminated. This type of radiological release typically involved gaseous and volatile isotopes of xenon, krypton, and iodine (U.S. Department of Energy, Nevada Operations Office [DOE/NV], 1996). 


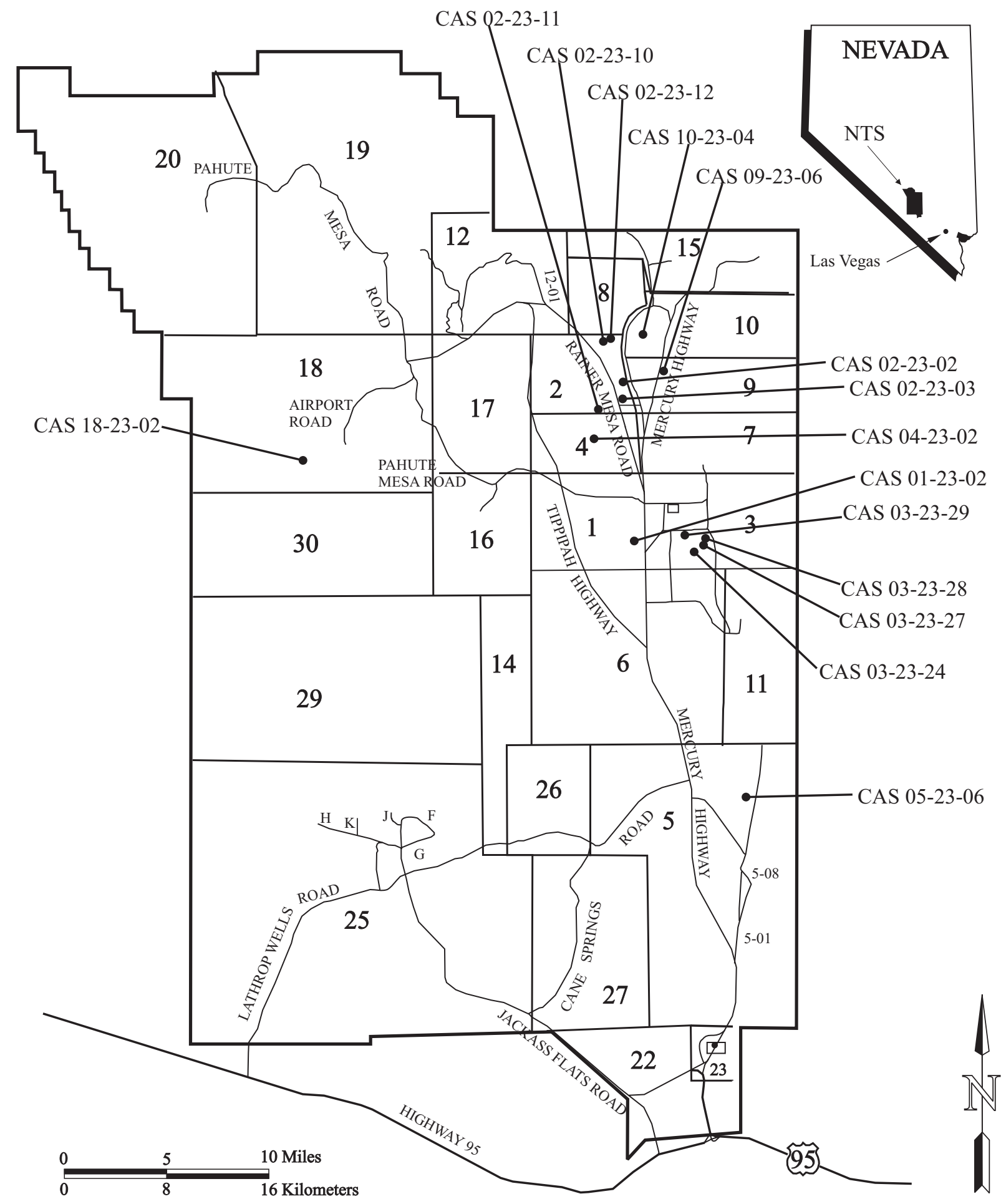

FIGURE 1

CORRECTIVE ACTION UNIT 107 Site Location MAP 
The operational nature of an underground detonation tends to fuse and confine fission products underground (U. S. Department of Energy [DOE], 1993). Additionally, Radiological Effluents Released from U.S. Continental Tests, 1961 through 1992, states, "Very few of the tests or simultaneous detonations resulted in particulate release with accompanying fallout of radioactive material" (DOE/NV, 1996).

Surface soils may have become radiologically contaminated from underground testing through post-test activities such as drill-backs and cable pulls. Drill-backs were holes drilled from the surface down to the cavity where the device had been detonated. Samples were collected to gather information to describe the performance of the nuclear device. Sample material was in containers; however, it was common for radiological readings to be elevated during these operations. This is because the radioactive sample material could be detected through the sample container and not typically because of surface soil contamination.

At some sites, instruments were attached to cables and placed underground with the nuclear device before it was detonated to measure test results. After the test, the instruments were pulled to the surface to assess performance aspects of the nuclear device. The cables attached to the instruments had the potential to be radiologically contaminated or, more likely, to be activated. Activation of these cables occurred by the same process by which soil activation occurs, as described in Section 2.1.2. These post-test activities have been perceived as a means of contaminating surface soils by bringing radioactive materials to the surface. However, historical data indicate that soils at the CAU 107 sites were not contaminated by these post-test activities.

\subsubsection{CASs ReSulting From FAR Above the Ground Detonations}

Three of the CASs in CAU 107 are associated with nuclear detonations that occurred in the atmosphere well above ground surface. The fireball, created when the nuclear device was detonated, could not draw materials, such as soil, into the contaminated plume because the detonations occurred too far off the ground; therefore, the soil in the area below the test detonation did not become contaminated (Spriggs, 2007).

Another way in which radioactive materials may be created through nuclear testing is by soil activation, which occurs when subatomic particles, neutrons, are given off in the detonation. The neutrons then interact with material such as soil. These interactions between neutrons and material cause the material to become radioactive. Detonations associated with these CASs were conducted too far above ground for the neutrons to significantly interact with soils or other materials at the ground surface (Spriggs, 2007).

\subsubsection{CAS Resulting From Near the Ground Surface Detonation}

The only CAS in CAU 107 that involved a detonation near the ground surface is CAS 04-23-02, which is associated with the RAY test. This atmospheric test was conducted by placing the nuclear device on a tower. Nuclear weapons tested at the NTS were of different sizes and designs, which resulted in different levels of explosive power, known as yield. In general, lower-yield atmospheric tests result in lower levels and smaller areas of contamination, while higher-yield tests result in more contamination dispersed over a larger area. This CAS is related to a lower-yield nuclear test of 200 tons (DOE/NV, 2000), so soils in this CAS have a low potential to be contaminated or activated. 


\subsection{DATA Sources}

Significant historical information and data are available for these sites. Because of this large amount of information and the very low potential for historical contaminant release or future contaminant transport, these sites are considered to be adequately characterized on the basis of existing data. The historical data indicate these sites may proceed through the SAFER process without the collection of additional data.

The following sections provide site descriptions, operational history, release information, and previous investigation results for each site. The information used in the development of this SAFER Plan falls into four general categories:

- Site Description Information: Provides the associated nuclear weapons test name, sources of potential contamination, and specific features included in the CAS

- Operational History: Provides process knowledge about the tests to determine if a distinct, test-related radiological release to surface soils occurred

- Release Information: Includes documentation from a variety of sources for the type of potential contaminant releases

- Historical Characterization Information: Includes a description of previous efforts to characterize, document, and/or evaluate the sites

These information sources are generally not quantitative; however, when evaluated together, they provide sufficient information to characterize the sites. The sections below discuss the data and how the data sources support one another. When evaluated together, these data sources are consistent with each other and with operational history. The data indicate that the sites will not cause an NTS worker dose greater than $25 \mathrm{mrem} / \mathrm{yr}$.

\subsubsection{SITE DESCRIPTION INFORMATION}

The Environmental Compliance group of a previous NTS contractor, Reynolds Electrical and Engineering Company, Inc. (REECo), performed a survey of abandoned facilities and disposal sites at the NTS in 1990 and 1991. The primary goal was to identify unknown environmental hazards related to chemicals regulated by the Comprehensive Environmental Response Compensation and Liability Act. This effort involved visits to several hundred sites and became the basis for creating many of the CASs listed in the FFACO. The results of this effort are published in Nevada Test Site Inventory of Inactive and Abandoned Facilities and Waste Sites (REECo, 1991). The REECo report does not include all of the CAU 107 CASs but was used to outline potential sources of radiological contamination and define the scope of the CAU 107 CASs (REECo, 1957; 1973a; 1973b).

\subsubsection{OPERATIONAL HISTORY}

Nuclear detonations associated with CAU 107 include eight atmospheric detonations (1951-1957) resulting in four CASs, and eleven underground detonations (1964-1972). Entities (national laboratories or contractors) of the DOE (formerly the U.S. Atomic Energy Commission [AEC]) prepared reports on the atmospheric tests soon after they were conducted. In addition, the U.S. Department of Defense (DoD) prepared a series of reports in the 1980s to document radiological effects to soldiers during atmospheric testing. Pertinent information from these documents is presented in this SAFER Plan. For the eleven sites associated with underground 
detonations, documents written by the NTS Management and Operations Contractor (M\&OC) and the national laboratories were reviewed for operational information related to the construction and conduct of the detonations. These historical documents provide information supporting conclusions regarding potential contaminant releases to the surface soils.

\subsubsection{RELEASE INFORMATION}

Two primary types of information were reviewed to evaluate the potential for test-related contaminant releases to the surface soils. These data sources are discussed below.

\subsubsection{Radiological Effluents Released from U.S. Continental Tests, 1961 through 1992}

This report includes compiled data for all radioactive releases associated with the underground nuclear testing program since 1961 (DOE/NV, 1996) for which there were documented releases. DOE/NV (1996) presents descriptive historical data concerning the types of releases and qualitative data on the types and relative amounts of radionuclides that were released to the environment as a result of the tests. The types and quantities of radioactive material released are presented. Releases from the underground nuclear tests associated with the following eleven sites are documented in DOE/NV (1996):

- CAS 02-23-02, Contaminated Areas (2)

- CAS 02-23-03, Contaminated Berm

- CAS 02-23-10, Gourd-Amber Contamination Area

- CAS 02-23-11, Sappho Contamination Area

- CAS 02-23-12, Scuttle Contamination Area

- CAS 03-23-24, Seaweed B Contamination Area

- CAS 03-23-27, Adze Contamination Area

- CAS 03-23-28, Manzanas Contamination Area

- CAS 03-23-29, Truchas-Chamisal Contamination Area

- CAS 09-23-06, Mound of Contaminated Soil

- CAS 18-23-02, U-18d Crater (Sulky)

Nine of the detonations related to the above-listed CASs are documented in DOE/NV (1996) as having a radiological release due to the detonation itself, and two sites have documented releases due to post-test activities. This type of radiological release typically involved gaseous and volatile isotopes of xenon, krypton, and iodine (DOE/NV, 1996). The nature of these releases and the impact to surface soils is discussed in Sections 2.3 through 2.17 of this SAFER Plan. CALABASH, which is associated with CAS 02-23-02, and GOURD-AMBER, which is associated with CAS 02-23-10, are not listed as having a radiological release of any kind.

Data presented in DOE/NV (1996) were compiled from classified and unclassified reports, memoranda, and letters prepared by the DOE, U.S. Public Health Service, U.S. Environmental Protection Agency (EPA), national laboratories, Defense Nuclear Agency (DNA) (predecessor to Defense Threat Reduction Agency [DTRA]), and DOE contractors. All data were reviewed by DOE health and safety personnel, national laboratories, EPA, and DTRA. The data presented in DOE/NV (1996) represent the consensus of opinion of the reviewing subject matter experts. 


\subsubsection{Radiological Safety and Health Reports}

Various measurements were collected during and immediately following the weapons tests. These measurements were collected to document the radiological conditions to which the public and test workers were exposed. The data collected quantified how much radioactivity was in the air and in what direction the wind carried the radioactivity. Information about the radiological condition of the surface soil in the test area was also gathered. The test director used this information to determine when it was safe for workers to enter the test area. The time at which the test director declared the area safe was called the Recovery Hour. Test workers were then allowed to enter the area to recover test equipment and instruments.

These data provided input to the CAS-specific conclusions reached in this SAFER Plan. Data showing that the radioactivity in air at a specific location decreased rapidly indicate that the radioactivity dispersed quickly and had a short half-life (Nuclear Data Center, 2006). This shows that the release consisted of gaseous radionuclides that did not collect in or on the surface soil. Data that quantified the amount of radioactivity remaining in the surface soils after the radioactive cloud dispersed indicated whether contamination was deposited in or on surface soils. A Recovery Hour was only established when the test had a reasonable potential to contaminate surface soils. A Recovery Hour was not established for some of the tests related to the CASs in CAU 107 as there was no reasonable potential for surface soil contamination to occur. A discussion of these data and the potential impact to surface soils due to test-related radiological releases is presented in the CAS-specific sections below.

\subsubsection{HISTORICAL CHARACTERIZATION INFORMATION}

Numerous characterization efforts have been conducted at the NTS since the tests at these sites occurred. Radiologically contaminated soils are typically characterized by several processes, including laboratory analysis of soil samples for, aerial radiological surveys, field screening with direct-reading survey equipment, and in situ gamma spectroscopy. The information presented in this SAFER Plan relies on aerial radiological data, field screening data, and in situ gamma spectroscopy data. Information about background radiation and characterization methods is presented below, and specific information for each CAS is presented in Sections 2.3 through 2.17 .

\section{Background Radiation}

Background radiation exists in the environment from natural and man-made sources. The background level of radioactivity in soil is the amount of radioactivity that cannot be attributed to a specific source but is due to low-level, worldwide natural and man-made sources. Background radiation at the NTS comes from two primary sources:

- Natural Sources: These are radioactive elements that occur naturally in the environment. The primary source at the NTS is uranium and its daughter products. Uranium is an ore that exists naturally in the earth's soils and is not a result of man-made activities. Another significant contribution comes from radon gas that is released from the earth's crust.

- Global Fallout: U.S. and foreign nuclear weapons testing resulted in widespread, low levels of radiological soil contamination called global fallout. Global fallout cannot be attributed to one specific test or group of tests but is residual contamination resulting from all tests performed worldwide. 


\section{Principles of Radiation Detection}

Radiological contamination is detected by several instruments. The instrumentation and survey method depends on the type of particles emitted and the material in which the radioactive element is deposited. Alpha particles are emitted from contaminants such as plutonium and uranium. Beta particles are emitted from contaminants such as strontium. Gamma rays are emitted from contaminants such as cesium, cobalt, and americium. Instrument selection also depends on information needs. Some instruments provide a yes or no determination of whether radiological contamination is present. Others quantify specific amounts of contamination for one or many radionuclides.

- Instrument-General Data: An ion chamber detects ionizing radiation and is capable of providing a yes or no indication of whether radiological contamination is present above background levels. Ion chambers measure exposure rates in units of roentgens per hour $(\mathrm{R} / \mathrm{hr})$. A roentgen is a measure of the amount of ionizing radiation in air. The scale of an ion chamber can be adjusted to read in smaller units, such as milliroentgens per hour ( $\mathrm{mR} / \mathrm{hr}$ ) (one-thousandth of an $\mathrm{R} / \mathrm{hr}$ ) or microroentgens per hour (microR/hr) (one millionth of an $\mathrm{R} / \mathrm{hr}$ ).

The Field Instrument for the Detection of Low-Energy Radiation (FIDLER) is an instrument that preferentially detects low-energy gamma rays such as those emitted by americium-241. Since americium-241 is a daughter product of plutonium-241, FIDLERs detect plutonium indirectly by detecting americium.

Aerial Radiological Survey data (fly-over data) are collected by a gamma ray detection instrument on a helicopter or airplane. Data can be analyzed and processed to meet many characterization goals and provide a yes or no indication of whether radiological contamination is present above background levels and the prevalent radionuclide. The data also show relative levels of total radiological contamination but do not provide radionuclide-specific quantities. The fly-over data show where there is no detectable contamination and areas of relatively higher contamination.

- Instrument-Specific Data: In situ gamma spectroscopy detects gamma ray emissions and allows for the quantification of specific radionuclide contaminant levels for multiple radionuclides. Gamma emissions occur at specific energies for each radionuclide. In situ gamma spectroscopy identifies different radioactive contaminants based on these emissions and their associated energies. This type of measurement technique is performed by taking direct measurements of radionuclide activity in place (in situ) without the need to collect and analyze soil samples. These measurements and the associated results are collected in real-time.

Quantities of non-gamma-emitting radionuclide contaminants can be inferred from gamma survey data. Soil samples are collected and analyzed in a laboratory to determine the amount and type of radioactivity present. These types of analyses can detect alpha- and beta-emitting radionuclides, such as plutonium and strontium. These same samples are also analyzed for gamma-emitting radionuclides, such as cesium, cobalt, and americium. Ratios between the gamma-emitting and non-gamma-emitting radionuclides are then calculated. Quantities of alpha- and beta-emitting radionuclides can be calculated by multiplying gamma survey results by this ratio. This approach allows a limited number of soil samples to be used to characterize large areas that have been radiologically surveyed. 
The primary characterization data used for the development of this SAFER Plan were collected by the methods discussed above. The sections below provide details on the specific characterization data sets used in this SAFER Plan.

\subsubsection{Aerial Radiological Surveys (Fly-Over Data)}

In 1994, the Remote Sensing Laboratory (RSL) conducted a site-wide fly-over survey with 100-percent coverage of the NTS (Hendricks and Riedhauser, 1999). Areas where radiological contamination was detected above background radiation levels were identified as regions of interest (ROIs). ROIs define areas of contamination directly related to a test or group of tests conducted in close proximity to one another. Numerous areas at the NTS were identified as ROIs. CAU 107 does not include any of these ROIs; however, closure of other Soils Sub-Project CAUs will address these ROIs.

Fly-over survey data analysis provided relative amounts of strong gamma-emitting radionuclides and americium-241. Americium-241 is a daughter product of plutionum-241, and the presence of americium generally means plutonium is also present.

Maps were produced showing relative amounts of contamination across the NTS and are presented in each CAS-specific section of this SAFER Plan. The methods are summarized in Aerial Radiological Surveys (Proctor, 1997). These data were used in this SAFER Plan to provide an indicator regarding the likelihood that a test-related radiological release to surface soils occurred at or near the CAS locations.

The following nine sites had no contamination detected on the 1994 fly-over survey:

- CAS 01-23-02, Atmospheric Test Site - High Alt

- CAS 02-23-02, Contaminated Areas (2)

- CAS 02-23-03, Contaminated Berm

- CAS 03-23-24, Seaweed B Contamination Area

- CAS 03-23-27, Adze Contamination Area

- CAS 03-23-28, Manzanas Contamination Area

- CAS 03-23-29, Truchas-Chamisal Contamination Area

- CAS 05-23-06, Atmospheric Test Site

- CAS 18-23-02, U-18d Crater (Sulky)

The following six sites had low levels of contamination detected on the 1994 fly-over survey:

- CAS 02-23-10, Gourd-Amber Contamination Area

- CAS 02-23-11, Sappho Contamination Area

- CAS 02-23-12, Scuttle Contamination Area

- CAS 04-23-02, Atmospheric Test Site T4-a

- CAS 09-23-06, Mound of Contaminated Soil

- CAS 10-23-04, Atmospheric Test Site M-10 
Operational history indicates the low levels of contamination identified at the six CASs listed above were not caused by test-related operations at these sites, but are due to contamination from other CASs not included in CAU 107. These other CASs are locations where atmospheric testing led to large, distinct contaminant plumes, and the above-listed CAS locations are within the edges of these known contaminant plumes. These plumes are associated with other Soils Sub-Project CAUs. Available data suggest that contamination identified in the above-listed CAS areas as part of CAU 107 will not lead to a worker dose greater than $25 \mathrm{mrem} / \mathrm{yr}$. However, closure of the atmospheric testing sites for the other CAUs will determine the appropriate 25-mrem/yr boundary. Sections 2.6, 2.8, 2.13, 2.15, and 2.16 of this SAFER Plan provide additional details.

\subsubsection{Nevada Test Site Contaminated Land Areas Report}

In 1998, the NTS M\&OC Radiological Control (RadCon) Department began what is known as the Demarcation Project, which systematically evaluated all previously identified radiologically contaminated areas at the NTS for compliance with 10 CFR 835, "Occupational Radiation Protection." 10 CFR 835 provides for different levels of radiological control depending on the level of radiological hazard present at the site (CFR, 1993). The purpose of this effort was to verify that the levels of radiological control were appropriate based on the hazards present, assure that proper fencing and postings were in place to control site access, and replace or update postings as necessary. Compliant control for areas of the NTS generally consists of the following types:

- Underground Radioactive Material Area (URMAs): These areas are controlled because there is contamination known or suspected to be present below the surface. These areas do not contain surface contamination that can be tracked from one location to another and are controlled to ensure workers do not perform subsurface work, such as excavation, without the appropriate work controls to mitigate the hazards.

- Radioactive Material Area (RMAs): These areas are controlled because there is contamination known or suspected to be present on the surface of the site but not in a form or at levels that can be tracked from one location to another. These areas are controlled to limit general access to workers.

- Contamination Areas: These areas are controlled because there is contamination known or suspected to be present on the surface of the site in a form and at levels that may be tracked from one location to another. These areas are controlled to limit the spread of contamination.

Measurements collected to determine what type of radiological controls were appropriate for the sites included exposure rate and FIDLER readings. Exposure rate measurements detect higher-energy gamma-emitting radionuclides, such as cesium-137, cobalt-60, and europium isotopes. FIDLER measurements detect americium-241, which, if present, implies plutonium is also present. These radionuclides are those that are commonly associated with nuclear testing. Traceable alpha and beta/gamma contamination was also assessed. The RadCon Department maintains a database of current postings. This effort is described in the Nevada Test Site Contaminated Land Areas Report (Bechtel Nevada [BN], 2000). The CASs in this SAFER Plan currently either require no radiological controls, are posted as URMAs, or are posted as RMAs. None of the areas require controls to limit the spread of contamination. The Demarcation Project monitors sites periodically to ensure continued compliance with 10 CFR 835 . 
The historical data presented in BN (2000) were evaluated to support the decisions made in this SAFER Plan. This type of data provides an indication of whether the surface soil is radiologically contaminated. Evaluation of the data, combined with information on existing radiological boundaries obtained from the current NTS M\&OC (National Security Technologies, LLC [NSTec]) RadCon Department, supports the conclusions derived from the operational history, release history, and aerial radiological survey data.

\subsubsection{Radionuclide Inventory and Distribution Program}

In 1981 DOE began conducting a thorough survey of contaminated surface soils at the NTS under the Radionuclide Inventory and Distribution Program (RIDP) using an in situ gamma spectroscopy technique developed by Lawrence Livermore National Laboratory (LLNL). In situ gamma spectroscopy provides radionuclide-specific levels of contamination in real-time without collecting soil samples. Edgerton, Germeshausen, and Grier Energy Measurements, Inc. and the Desert Research Institute (DRI) performed the work, which included five years of field work and an additional three years of analysis. The results were published in five reports (McArthur and Kordas, 1983; 1985; McArthur and Mead, 1987; 1988; 1989). A summary report was also published (McArthur, 1991) that provided an integrated estimate of the levels of soil radioactivity at the NTS, including estimated quantities of the 16 most significant man-made radionuclides produced by nuclear weapons testing.

Aerial radiological survey data collected between 1976 and 1984 were used to plan locations for the in situ measurements. Generally, the RIDP took many measurements on a tight grid in known radiologically contaminated areas, while areas of lower contamination involved fewer measurements spaced further apart. Some measurements were also collected in areas that were not expected to be radiologically contaminated. Where radionuclide levels were greater than what is attributable to widespread global fallout, the radionuclides were assumed to result from NTS activities. The RIDP surveyed all areas where aboveground tests had been conducted and where other localized sources of contamination may be present, such as waste dumps. The only known areas of surface radioactivity not surveyed were a few rugged highland areas and craters where the survey vehicle could not safely access the sites.

The RIDP also collected soil samples at selected locations in increments from the surface down to 15 centimeters below ground surface to determine the distribution of radionuclides with depth. The contaminant distribution with depth is not uniform at the NTS. Most radionuclides are concentrated in the top several centimeters of soil. Understanding this distribution allowed the RIDP to accurately quantify the amount of contamination present.

Contaminant levels for gamma-emitting radionuclides were determined through direct measurements; however, soil samples were collected in order to quantify contaminant levels of non-gamma-emitting radionuclides. These results allowed the RIDP to determine contaminant levels for all radionuclides suspected to be present.

For this SAFER Plan, the RIDP data were plotted using geographic information system software. The RIDP data locations were plotted with the 1994 aerial survey fly-over data, and these maps are presented in each CAS-specific section of this SAFER Plan. Where RIDP data were collected near the CASs, the data were used qualitatively to support the conclusions drawn from the historical process knowledge, release information, aerial survey data, and BN (2000) survey data. 
Radiological dose is a way to quantify increased risk to human health due to exposure to radiation. The RIDP data provide radionuclide-specific activity results for all measurement locations. These data can be used to estimate radiological dose. The risk-based approach to closure of radiologically contaminated sites establishes a dose (or risk) that is considered acceptable in that it does not cause undue harm to individuals using the contaminated lands. The Industrial Sites Federal Sub-Project established this risk level at $25 \mathrm{mrem} / \mathrm{yr}$ for an NTS worker. Doses are not measured directly, but are calculated using models that consider the amount of contamination present and how the land will be used.

These models can also derive the amount of residual contamination that will cause an individual to receive the dose limit. The model calculates a limit for soil contamination for a given dose limit, such as $25 \mathrm{mrem} / \mathrm{yr}$. These soil concentration limits are called Derived Concentration Guides (DCGs). DCGs were not calculated in this SAFER Plan; however, comparisons were made to the DCGs set forth in Development of the Scientific Basis for Establishing the Boundary Conditions Between "Unrestricted Use" and "Posting" for Exposure Due to Residual Radioactive Contamination of Soil at the Nevada Test Site (Anspaugh and Daniels, 1995). This comparison was made to augment process knowledge and other characterization information and is not intended as a formal dose assessment. RIDP data were used as follows:

- The DCGs set forth in Anspaugh and Daniels (1995) were based on a 100-mrem/yr dose to an NTS worker, not a 25-mrem/yr dose as negotiated with the Nevada Division of Environmental Protection for the Industrial Sites Federal Sub-Project. Therefore, the DCGs had to be adjusted downward to reflect a $25-\mathrm{mrem} / \mathrm{yr}$ dose and were reduced to a quarter of the published limit.

- RIDP values were compared to the adjusted DCGs using the sum of the fractions approach. This approach is commonly used when multiple radionuclides are present, as it allows for the incremental dose from each radionuclide to be added together. Since the DCG for each radionuclide is different, this method normalizes each radionuclide's contribution to dose by calculating a fraction. The fractional contribution to dose that each radionuclide makes is the concentration of the radionuclide divided by that radionuclide's associated DCG. If the concentration result is less than its associated DCG, the fraction will be less than 1 . If the concentration is greater than its associated DCG, the fraction will be greater than 1. A fraction less than 1 indicates that the DCG has not been exceeded, while a fraction greater than 1 indicates the DCG has been exceeded. It is possible that no single radionuclide is greater than its associated DCG, but when the small contribution from each radionuclide is added together, the sum of these contributions exceeds the limit.

An example follows:

- The concentration of plutonium-238 divided by its associated DCG is 0.5 .

- The concentration of cesium-137 divided by its associated DCG is 0.75 .

$\circ$ These fractions are added together, and the result is 1.25. In other words, the total DCG is exceeded, even though no single radionuclide is above its associated DCG.

- The sum of the fractions was calculated for each RIDP result as discussed above.

- Measurements with a sum of the fractions greater than 1 indicate a possible dose to workers greater than $25 \mathrm{mrem} / \mathrm{yr}$. 
The limits in Anspaugh and Daniels (1995) are conservative in that they assume worker residence time is 2,000 hours per year. This is equivalent to the Industrial Use Scenario, defined in Industrial Sites Project Establishment of Final Action Levels (NNSA/NSO, 2006b), that assumes the worker residence time is 1,800 hours.

The CASs in this SAFER Plan fall into the Occasional Use Scenario that assumes a worker residence time of 80 hours per year. Comparing the Anspaugh and Daniels (1995) limits to those derived for the Occasional Use Scenario is very conservative. The DCGs used in this SAFER Plan assume a worker will be exposed to radiation 25 times longer than what is assumed for the most realistic worker exposure scenario of 80 hours per year.

This evaluation indicates that no measurements at or near the CAS locations exceed the conservative, adjusted DCGs; in other words, the potential dose to an NTS worker is less than $25 \mathrm{mrem} / \mathrm{yr}$ for all CASs in CAU 107.

\subsection{CAS 01-23-02, ATMOSPHERIC TeSt Site - High Alt}

CAS 01-23-02 was designated to address potential surface soil contamination associated with the HA (HIGH ALTITUDE) nuclear weapons test. This test was detonated at approximately 40,000 feet (ft) above mean sea level (amsl) (DOE/NV, 2000). This test left no surface impression, and there is no distinct contamination plume associated with this CAS. Ground zero does not exist for this test given the height of detonation. Postings are not required at this CAS location under requirements of 10 CFR 835. Field visits were made to this CAS on January 9 and 10, 1996, and May 11, 2006. Site visits in 1996 confirmed that there were no fenced areas and no postings. Field crew and vehicles were surveyed upon completion of the field visit. No readings were detected above background levels. During the 2006 site visit, no postings or fencing were observed other than the site marker placed during the 1996 field visit.

\subsubsection{OPERATIONAL HISTORY}

The HA test, conducted on April 6, 1955, was part of Operation Teapot. The test had a 3-kiloton (kt) yield (DOE/NV, 2000). The HA nuclear device was dropped from an airplane and detonated well above the ground surface, causing a wide, swift dispersion pathway. Aircraft were sampling radioactivity in the air over the NTS during the HA test. Three of the four sampling aircraft could not fly high enough to collect air samples because the radioactive cloud wafted higher than the airplane could fly. Pilots flying the sampling aircraft reported that the HA cloud dissipated rapidly and was difficult to see (DNA, 1981).

The test director did not establish a Recovery Hour because no significant radioactive fallout was observed and such precautions were not needed. Post-test aerial surveys of terrain were not conducted due to the height of detonation and because no significant onsite radioactive fallout was detected during the test. Ground-based radiological safety support was not needed for this test, as radiological fallout was not expected to reach the ground surface. The HA test caused no significant onsite radiological fallout. As a result, ground-based surveys were unnecessary, and no protective clothing or radiation survey meters were issued to project personnel (DNA, 1981). 


\subsubsection{RELEASE INFORMATION}

The HA test caused a radiological release to the air space above the NTS. However, process knowledge and operational history strongly indicate that the HA test did not cause radiological contamination of surface soils within the boundaries of the NTS. Surface radiological contamination produced by a nuclear test conducted close to ground surface is largely due to materials (soils and tower material) being drawn into the resulting radioactive cloud (DNA, 1981). Since this test was detonated at 40,000 ft amsl, this process did not occur (Spriggs, 2007). Figure 2 is a photograph of the HA detonation and shows that no material was drawn into the area at detonation. The contrails were created by test aircraft prior to the detonation to measure nuclear blast characteristics.

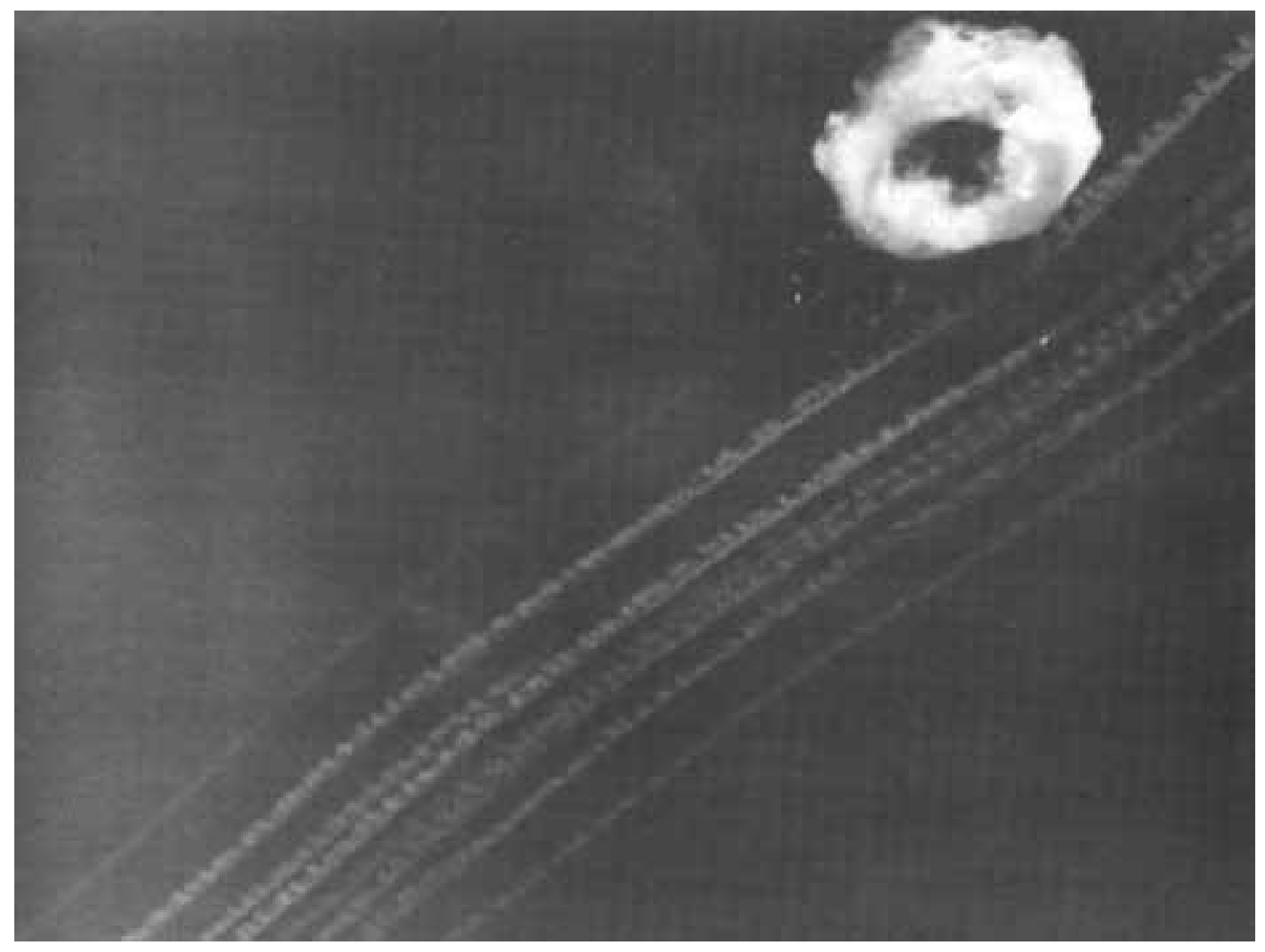

Figure 2. HA DETONATION 


\subsubsection{HiSTORICAL CHARACTERIZATION INFORMATION}

The following data were used to evaluate the potential surface release for CAS 01-23-02 and determine the likelihood of a release to the surface soils in the area resulting from the HA test.

\subsubsection{Fly-Over Data}

The 1994 fly-over survey does not show detectable levels of radionuclides in the area of this CAS and does not identify any nearby areas as ROIs (Hendricks and Riedhauser, 1999). The fly-over survey process is well established and has been used at many sites to make the "yes-no" type of decision used in this SAFER Plan (NNSA/NSO, 2005). The fly-over data are used in a semi-quantitative way to support the conclusion based on operational history that a release to surface soils did not occur as a result of HA operations. There were 141 measurements collected within a 500-meter $(\mathrm{m})$ radius of the HA site (Figure 3 ). While the fly-over data, depicted in Figure 3, are shown as points, the field of view of the detector is large; thus, the fly-over survey provided 100-percent coverage of this area. These data were analyzed as described in Proctor (1997) and Hendricks and Riedhauser (1999). The results of the analyzed survey data are shown in Table 1. All measurements were less than the detection limit of the instrumentation.

TABle 1. CAS 01-23-02 Fly-OVER DATA SUMmary

\begin{tabular}{||l|c|c|c||}
\hline \hline MEASUREMENT TYPE & $\begin{array}{c}\text { NUMBER OF } \\
\text { MEASUREMENTS }\end{array}$ & $\begin{array}{c}\text { APPROXIMATE } \\
\text { DETECTION LIMIT }\end{array}$ & $\begin{array}{c}\text { NUMBER } \\
\text { MEASUREMENTS } \\
\text { >DETECTION LIMIT }\end{array}$ \\
\hline Total man-made & 141 & $1.5 \mathrm{microR} / \mathrm{hr}$ & 0 \\
\hline americium-241 & 141 & $50 \mathrm{cps}$ & 0 \\
\hline
\end{tabular}

The fly-over data presented above represent many individual measurements (referred to as point data), and each measurement is corrected for background radiation. The fly-over survey process continuously collects background radiation levels. Each gross measurement is then corrected to remove background radiation levels, resulting in data that show the added man-made radiation from testing or other activities. The fly-over measurements for total man-made radiation are very sensitive, with the detection limit of $1.5 \mathrm{microR} / \mathrm{hr}$. Typical background exposure rates are approximately $15 \mathrm{microR} / \mathrm{hr}$. Thus, the detection limit of $1.5 \mathrm{microR} / \mathrm{hr}$ results in detection of man-made radiation that is greater than approximately 10 percent of natural background radiation.

The fly-over surveys are very sensitive to americium-241. Americium-241 sensitivity is approximately 50 counts per second (cps). A specific correlation to soil concentration values was not performed; however, a conservative correlation of $50 \mathrm{cps}$ to 300 nanocuries per square meter $\left(\mathrm{nCi} / \mathrm{m}^{2}\right)$ has been estimated by RSL based on other similar flights and the flight altitude of $200 \mathrm{ft}$. This value, $300 \mathrm{nCi} / \mathrm{m}^{2}$, was then compared to RIDP measurements made in non-operational areas of the NTS where no local releases of radioactive material occurred to determine whether the fly-over survey is capable of discerning levels of radioactivity indicative of a widespread radiological release. Since the RIDP values in the non-operational areas range from 24 to $573 \mathrm{nCi} / \mathrm{m}^{2}$ and the fly-over sensitivity is approximately $300 \mathrm{nCi} / \mathrm{m}^{2}$, this shows that the fly-over survey is capable of discerning where operational releases have occurred. No americium-241 fly-over survey measurements were greater than the detection limit, similar to the non-operational areas of the NTS. These data confirm that there was not a widespread release to surface soils. 


\subsubsection{Contaminated Land Report Data}

Radiological surveys conducted for BN (2000) did not include this CAS location because radiological contamination was not suspected in the area.

\subsubsection{3 $\quad \underline{\text { RIDP Data }}$}

Several RIDP measurements were taken within $500 \mathrm{~m}$ of the HA site (McArthur and Mead, 1987) (Figure 3). RIDP values were used to evaluate operational history and support the conclusion that the HA detonation did not lead to a widespread contaminant release to surface soils. RIDP measurements taken within $500 \mathrm{~m}$ of the HA site were evaluated against limits set forth in Anspaugh and Daniels (1995) as explained in Section 2.2.4.3 of this SAFER Plan. Table 2 provides the maximum, minimum, and average values of these data and compares the maximum value to the limits set forth in Anspaugh and Daniels (1995). All values are well below these limits. This evaluation is not intended as a formal dose assessment but as a means by which these data may be compared to evaluate the validity of the operational history release assumptions.

Results for strong gamma-emitting radionuclides measured by RIDP in the HA vicinity and at the non-operational areas where releases did not occur were compared. All HA maximum values were within the range of the values measured at the non-operational areas. While still within the range of values for non-operational areas, there are two RIDP values in the northern portion of the HA area with slightly elevated americium-241 and plutonium values. However, the HA weapon used a uranium core; therefore, these slightly elevated values are not attributable to HA activities. These results support the process knowledge and fly-over data.

TABLE 2. CAS 01-23-02 RIDP DATA SUMMARY

\begin{tabular}{|l|r|r|r|r|r||}
\hline RADIONUCLIDE & $\begin{array}{c}\text { NUMBER OF } \\
\text { MEASUREMENTS }\end{array}$ & $\begin{array}{c}\text { MAXIMUM } \\
\text { VALUE } \\
\left(\mathrm{nCi} / \mathrm{m}^{2}\right)\end{array}$ & $\begin{array}{c}\text { MINIMUM } \\
\text { VALUE } \\
\left(\mathrm{nCi} / \mathrm{m}^{2}\right)\end{array}$ & $\begin{array}{c}\text { AVERAGE } \\
\text { VALUE } \\
\left(\mathrm{nCi} / \mathrm{m}^{2}\right)\end{array}$ & $\begin{array}{c}\text { MAX VALUE } \\
\text { FRACTION OF } \\
\text { DCG }\end{array}$ \\
\hline americium-241 & 4 & 240.47 & 78.70 & 166.10 & 0.10 \\
\hline barium-133 & 4 & 0.00 & 0.00 & 0.00 & 0.00 \\
\hline cobalt-60 & 4 & 0.69 & 0.57 & 0.65 & 0.00 \\
\hline cesium-137 & 4 & 71.89 & 54.94 & 63.06 & 0.02 \\
\hline europium-152 & 4 & 12.68 & 12.50 & 12.59 & 0.01 \\
\hline europium -154 & 4 & 13.70 & 10.50 & 11.85 & 0.01 \\
\hline europium -155 & 4 & 0.93 & 0.90 & 0.92 & 0.00 \\
\hline plutonium-238 & 4 & 143.61 & 47.00 & 99.19 & 0.02 \\
\hline plutonium -239 & 4 & 1501.31 & 663.31 & 1399.98 & 0.29 \\
\hline strontium-90 & 4 & 231.15 & 176.65 & 202.73 & 0.00 \\
\hline
\end{tabular}

\subsubsection{CONCLUSION}

The HA detonation occurred at approximately 40,000 ft amsl and did not cause surface radiological contamination at or near this CAS. This is supported by process knowledge, 100-percent coverage fly-over survey data, and RIDP data. The demonstrated lack of radiological releases to the surface soils in the vicinity of CAS 01-23-02 leads to the conclusion that there is no credible exposure pathway that could cause an NTS worker to receive a dose greater than $25 \mathrm{mrem} / \mathrm{yr}$ at this CAS.

This CAS requires no additional controls under the FFACO. Based on the information presented above, data are adequate to support a closure option of no further action. 


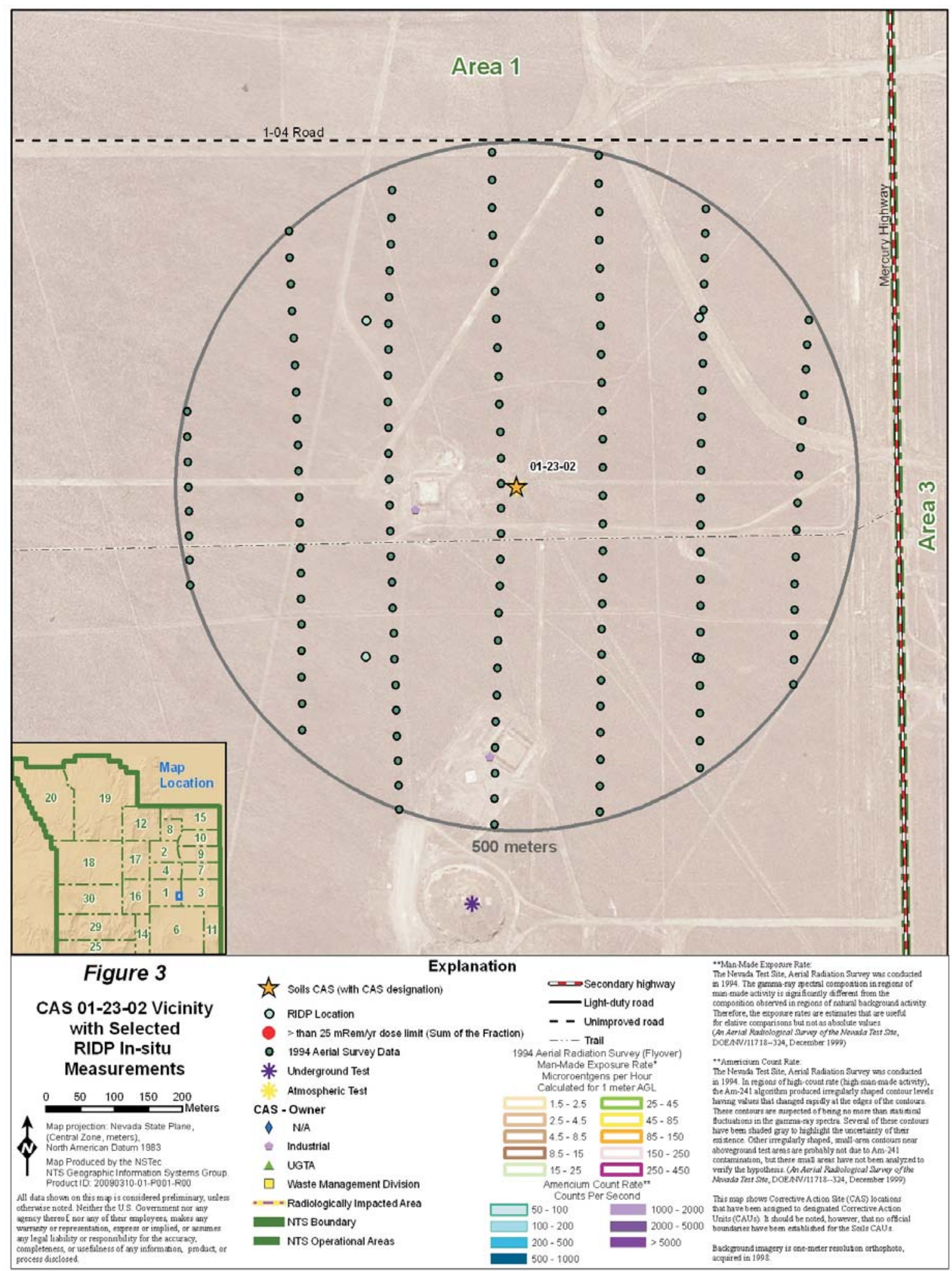

FIGURE 3 


\subsection{CAS 02-23-02, CONTAMINATED AREAS (2)}

CAS 02-23-02 is associated with a potential surface release that occurred during post-test drilling activities near the CALABASH underground detonation site. While a release did not result from the CALABASH detonation itself, operational history indicated that elevated exposure rate readings were noted during post-test drilling. In addition, alpha contamination was detected on a core shoe that had been down-hole. The CAS boundary encompasses the two locations (cellars) where the post-test drilling operations occurred (U-2av PS\#1A and U-2av PS\#2A). The boreholes were previously plugged and the cellars are backfilled. The cellars are not included in the scope of the CAS. The scope of the CAS is limited to potential surface contamination that resulted from the post-test drilling. The CALABASH detonation cavity is part of the Underground Test Area (UGTA) Sub-Project.

\subsubsection{OPERATIONAL HISTORY}

The CALABASH test, conducted on October 29, 1969, was part of Operation Mandrel. The test, detonated in emplacement hole U-2av, had a 110-kt yield (DOE/NV, 2000). Post-test drilling was conducted near the CALABASH test location at borehole numbers U-2av PS\#1A and U-2av PS\#2A. The FFACO describes this CAS as "Contaminated Areas (2)." Radiological contamination was suspected to be present at the surface due to elevated exposure rates detected during post-test drilling conducted at borehole PS\#2A and because removable alpha contamination was detected on a core shoe used during post-test drilling operations at this borehole (REECo, 1973a). The maximum gamma exposure rate measured at borehole PS\#2A was $6.0 \mathrm{mR} / \mathrm{hr}$. Borehole PS\#1A was abandoned prior to reaching the detonation cavity; therefore, surface contamination was not suspected in this area. Subsequent surveys by the radiological demarcation group did not identify surface contamination at either cellar location, and they are posted as URMAs. The URMA postings are historical, likely because they were associated with the post-test boreholes.

\subsubsection{RELEASE INFORMATION}

There was not a surface radiological release from the CALABASH detonation itself (DOE/NV, 1996). While elevated exposure rate readings were noted during post-test drilling operations at borehole PS\#2A (REECo, 1973a), operational history indicates this type of elevated reading was typical of post-test drilling and sampling operations and is not a unique indicator of surface radiological contamination. The post-test holes were drilled in order to collect radiological samples; therefore, elevated readings were often observed due to the release of gaseous radionuclides or elevated radioactivity emanating from within the sample container. DOE/NV (1996) does not document a radiological release from the CALABASH detonation or from post-test operations; thus, it is concluded that elevated exposure rate measurements were from the contained sample material and not from soil contamination or other surface release.

In addition, a single alpha-contaminated swipe was collected from a core shoe. The swipe was collected from equipment that had been down-hole and not collected from either the drilling platform or the general work area (REECo, 1973a). This swipe is not an indicator of surface soil contamination. 


\subsubsection{HistoricAl CHARACTERIZATION INFORMATION}

The following data were used to evaluate the potential surface release for CAS 02-23-02 and determine the likelihood of a release to the surface soils in the area resulting from CALABASH.

\subsubsection{Fly-Over Data}

The 1994 fly-over survey does not show detectable levels of radionuclides in the area of this CAS and does not identify any nearby areas as ROIs (Hendricks and Riedhauser, 1999). The fly-over survey process is well established and has been used at many sites to make the "yes-no" type of decision used in this SAFER Plan (NNSA/NSO, 2005). The fly-over data have been used in a semi-quantitative way to support the conclusion based on operational history that a release to surface soils did not occur as a result of operations at borehole PS\#2A. As stated previously, there was not a release to surface soils resulting from the CALABASH detonation itself. There were 129 measurements collected within a 500-m radius of the CALABASH detonation (Figure 4). While the fly-over data, depicted in Figure 4, are shown as points, the field of view of the detector is large; thus, the fly-over survey provided 100-percent coverage of this area. These data were analyzed as described in Proctor (1997) and Hendricks and Riedhauser (1999). The results of the analyzed survey data are shown in Table 3. All measurements were less than the detection limit of the instrumentation.

TABle 3. CAS 02-23-02 Fly-OVer DATA SumMary

\begin{tabular}{||l|c|c|c||}
\hline MEASUREMENT TYPE & $\begin{array}{c}\text { NUMBER OF } \\
\text { MEASUREMENTS }\end{array}$ & $\begin{array}{c}\text { APPROXIMATE } \\
\text { DETECTION LIMIT }\end{array}$ & $\begin{array}{c}\text { NUMBER } \\
\text { MEASUREMENTS } \\
\text { >DETECTION LIMIT }\end{array}$ \\
\hline Total man-made & 129 & $1.5 \mathrm{microR} / \mathrm{hr}$ & 0 \\
\hline americium-241 & 129 & $50 \mathrm{cps}$ & 0 \\
\hline
\end{tabular}

The fly-over data presented above represent many individual measurements (referred to as point data), and each measurement is corrected for background radiation. The fly-over survey process continuously collects background radiation levels then corrects each measurement to remove it, resulting in data that show the added man-made radiation from testing or other activities. The fly-over measurements for total man-made radiation are very sensitive, with a detection limit of $1.5 \mathrm{microR} / \mathrm{hr}$. Typical background exposure rates are approximately $15 \mathrm{microR} / \mathrm{hr}$. Thus, the detection limit of $1.5 \mathrm{microR} / \mathrm{hr}$ results in detection of man-made radiation that is greater than approximately 10 percent of natural background radiation. No measurement for total man-made radiation at or within $500 \mathrm{~m}$ of the CALABASH detonation site exceeds this detection limit.

The fly-over surveys are very sensitive to americium-241. Americium-241 sensitivity is approximately $50 \mathrm{cps}$. A specific correlation to soil concentration values was not performed; however, a conservative correlation of $50 \mathrm{cps}$ to $300 \mathrm{nCi} / \mathrm{m}^{2}$ has been estimated by RSL based on other similar flights and the flight altitude of $200 \mathrm{ft}$. This value, $300 \mathrm{nCi} / \mathrm{m}^{2}$, was then compared to RIDP measurements made in non-operational areas of the NTS where no local releases of radioactive material occurred to determine whether the fly-over survey is capable of discerning levels of radioactivity indicative of a widespread radiological release. Since the RIDP values in the non-operational areas range from 24 to $573 \mathrm{nCi} / \mathrm{m}^{2}$ and the fly-over sensitivity is approximately $300 \mathrm{nCi} / \mathrm{m}^{2}$, this shows that the fly-over survey is capable of discerning where operational releases have occurred. No americium-241 fly-over survey measurements were greater than the detection limit, similar to the non-operational areas of the NTS. These data confirm that there was not a widespread release to surface soils. 


\subsubsection{Contaminated Land Report Data}

Results of the surveys conducted in support of BN (2000) were used qualitatively to support the conclusions derived from the operational history. The surveys conducted for BN (2000) included radiological surveys in the immediate area of CAS 02-23-02. Measurements collected included exposure rates and FIDLER readings. Removable alpha and beta/gamma contamination were also assessed. Measurements were collected within the boundaries of URMAs and around the perimeter of these areas. Table 4 presents the results of these surveys (BN, 2000).

\section{TABle 4. CAS 02-23-02 Contaminated LANd SuRvey Data Summary}

\begin{tabular}{|c|c|c|c|c|c|}
\hline $\begin{array}{l}\text { MEASUREMENT } \\
\text { TYPE }\end{array}$ & $\begin{array}{c}\text { NUMBER OF } \\
\text { MEASUREMENTS }\end{array}$ & $\begin{array}{l}\text { MAXIMUM } \\
\text { VALUE }\end{array}$ & $\begin{array}{l}\text { MINIMUM } \\
\text { VALUE }\end{array}$ & $\begin{array}{l}\text { AVERAGE } \\
\text { VALUE }\end{array}$ & $\begin{array}{l}\text { APPROXIMATE } \\
\text { INSTRUMENT } \\
\text { SENSITIVITY }^{1} \\
\end{array}$ \\
\hline Removable Alpha & 14 & $2 \mathrm{dpm} / 100 \mathrm{~cm}^{2}$ & $0 \mathrm{dpm} / 100 \mathrm{~cm}^{2}$ & $0.14 \mathrm{dpm} / 100 \mathrm{~cm}^{2}$ & $5 \mathrm{dpm} / 100 \mathrm{~cm}^{2}$ \\
\hline Removable Beta & 14 & $12 \mathrm{dpm} / 100 \mathrm{~cm}^{2}$ & $0 \mathrm{dpm} / 100 \mathrm{~cm}^{2}$ & $1.1 \mathrm{dpm} / 100 \mathrm{~cm}^{2}$ & $16 \mathrm{dpm} / 100 \mathrm{~cm}^{2}$ \\
\hline Exposure Rate & 14 & $80 \mathrm{uR} / \mathrm{hr}$ & $10 \mathrm{uR} / \mathrm{hr}$ & $19 \mathrm{uR} / \mathrm{hr}$ & $20 \mathrm{uR} / \mathrm{hr}^{1}$ \\
\hline FIDLER & 14 & $85 \mathrm{cps}$ & $75 \mathrm{cps}$ & $78 \mathrm{cps}$ & $100 \mathrm{cps}$ \\
\hline
\end{tabular}

${ }^{1}$ Approximate Instrument Sensitivity is estimated based on typical background values and instrument performance. All values reported below the instrument sensitivity are estimates only.

All values were below detection limits except for one isolated exposure rate reading. However, a site visit was conducted in 2007 , and no anomalous radiological readings were measured, indicating that the previously elevated reading is no longer representative of site conditions. These ground-based survey data consist of measurements that are focused in the post-test drilling areas in and around the URMAs, thereby augmenting the wide-area data collected via fly-over surveys. These data provide an additional resource indicating that post-test drilling operations did not lead to surface soil contamination.

The NV/YMP RadCon Manual (NNSA/NSO, 2004b) is used at the NTS to implement the requirements set forth in $10 \mathrm{CFR} 835$. The manual allows for the release of areas from radiological controls when certain radiological limits are met. The limits were established as acceptable levels for use by the general public, and thus, are conservative given the ongoing controls at CAS 02-23-02 and the lack of both public and worker access to the site. Table 5 outlines these release values. BN (2000) survey measurements in the area of CAS 02-23-02 are well below the radiological control limits outlined in Table 5.

\subsubsection{3 $\quad \underline{\text { RIDP Data }}$}

Several RIDP measurements were taken within $500 \mathrm{~m}$ of the CALABASH site (Figure 4). RIDP values were used to evaluate operational history and support the conclusion that the elevated exposure rate readings observed during the drilling operations did not indicate a widespread contaminant release. RIDP measurements taken within $500 \mathrm{~m}$ of the CALABASH site were evaluated against limits set forth in Anspaugh and Daniels (1995) as explained in Section 2.2.4.3 of this SAFER Plan. Table 6 provides the maximum, minimum, and average values of these data and compares the maximum value to the limits set forth in Anspaugh and Daniels (1995). All values are well below these limits. This evaluation is not intended as a formal dose assessment but as a means by which these data may be compared to evaluate the validity of the operational history release assumptions. 


\section{TABle 5. Surface Contamination Release VALUES ${ }^{1}$ IN DPM/100 CM$^{2}$}

\begin{tabular}{||l|l|l||}
\hline \multicolumn{1}{|c|}{ RADIONUCLIDES } & REMOVABLE $^{2,4}$ & $\begin{array}{c}\text { TOTAL (FIXED } \\
+ \text { REMOVABLE) }^{2,3}\end{array}$ \\
\hline $\begin{array}{l}\text { natural uranium, uranium-235, uranium-238, and associated decay } \\
\text { products }\end{array}$ & $1,000^{7}$ & $5,000^{7}$ \\
\hline $\begin{array}{l}\text { transuranics, radium-226, radium-228, thorium-230, thorium-228, } \\
\text { protactinium-231, actinium-227, iodine-125, and iodine-129 }\end{array}$ & 20 & 500 \\
\hline $\begin{array}{l}\text { natural thorium, thorium-232, strontium-90, radium-223, radium-224, } \\
\text { uranium-232, iodine-126, iodine-131, and iodine-133 }\end{array}$ & 200 & 1,000 \\
\hline $\begin{array}{l}\text { beta-gamma emitters (nuclides with decay modes other than alpha } \\
\text { emission or spontaneous fission), except strontium-90 and others } \\
\text { noted above }\end{array}$ & 1,000 & 5,000 \\
\hline tritium and tritiated compounds $^{6}$ & 10,000 & N/A \\
\hline
\end{tabular}

1 The values in this table, with the exception noted in footnote 5, apply to radioactive contamination deposited on, but not incorporated into the interior or matrix of, the contaminated item. Where surface contamination by both alpha and beta-gamma-emitting nuclides exists, the limits established for alpha and beta-gamma-emitting nuclides apply independently.

2 As used in this table, dpm (disintegrations per minute) means the rate of emission by radioactive material as determined by correcting the counts per minute observed by an appropriate detector for background, efficiency, and geometric factors associated with the instrumentation.

3 The levels may be averaged over 1 square meter provided the maximum surface activity in any area of $100 \mathrm{~cm}^{2}$ is less than three times the value specified. For purposes of averaging, any square meter of surface shall be considered to be above the surface contamination value if: (1) From measurements of a representative number of sections it is determined that the average contamination level exceeds the applicable value; or (2) it is determined that the sum of the activity of all isolated spots or particles in any $100 \mathrm{~cm}^{2}$ area exceeds three times the applicable value.

4 The amount of removable radioactive material per $100 \mathrm{~cm}^{2}$ of surface area should be determined by swiping the area with dry filter or soft absorbent paper, applying moderate pressure, and then assessing the amount of radioactive material on the swipe with an appropriate instrument of known efficiency. (Note: The use of dry material may not be appropriate for tritium.) When removable contamination on objects of surface area less than $100 \mathrm{~cm}^{2}$ is determined, the activity per unit area shall be based on the actual area and the entire surface shall be wiped. It is not necessary to use swiping techniques to measure removable contamination levels if direct scan surveys indicate that the total residual surface contamination levels are within the limits for removable contamination.

5 This category of radionuclides includes mixed fission products, including strontium- 90 present in them. It does not apply to strontium- 90 which has been separated from the other fission products or mixtures where the strontium- 90 has been enriched.

6 Tritium contamination may diffuse into the volume or matrix of materials. Evaluation of surface contamination shall consider the extent to which such contamination may migrate to the surface in order to ensure the surface contamination value provided in this appendix is not exceeded. Once this contamination migrates to the surface, it may be removable, not fixed; therefore, a "Total" value does not apply.

7 (alpha)

TABLE 6. CAS 02-23-02 RIDP DATA SUMMARY

\begin{tabular}{|c|c|c|c|c|c|}
\hline RADIONUCLIDE & $\begin{array}{c}\text { NUMBER OF } \\
\text { MEASUREMENTS }\end{array}$ & $\begin{array}{c}\text { MAXIMUM } \\
\text { VALUE } \\
\left(\mathrm{nCi} / \mathrm{m}^{2}\right)\end{array}$ & $\begin{array}{l}\text { MINIMUM } \\
\text { VALUE } \\
\left(\mathrm{nCi} / \mathrm{m}^{2}\right)\end{array}$ & $\begin{array}{l}\text { AVERAGE } \\
\text { VALUE } \\
\left(\mathrm{nCi} / \mathrm{m}^{2}\right)\end{array}$ & $\begin{array}{c}\text { MAX VALUE } \\
\text { FRACTION OF } \\
\text { DCG }\end{array}$ \\
\hline americium-241 & 4 & 40.89 & 36.37 & 37.98 & 0.02 \\
\hline barium-133 & 4 & 5.41 & 4.3 & 4.62 & 0 \\
\hline cobalt-60 & 4 & 1.15 & 0.6 & 0.9 & 0 \\
\hline cesium-137 & 4 & 145.71 & 52.25 & 105.03 & 0.04 \\
\hline europium-152 & 4 & 49.83 & 13.04 & 30.65 & 0.03 \\
\hline europium -154 & 4 & 38.12 & 12.37 & 24.27 & 0.02 \\
\hline europium -155 & 4 & 0.89 & 0.78 & 0.83 & 0 \\
\hline plutonium-238 & 4 & 65.424 & 58.192 & 60.768 & 0.01 \\
\hline plutonium -239 & 4 & 269.874 & 240.042 & 250.668 & 0.05 \\
\hline strontium-90 & 4 & 269.62 & 96.67 & 194.34 & 0 \\
\hline
\end{tabular}

Results for radionuclides measured by RIDP in the CALABASH vicinity and at the non-operational areas where releases did not occur were compared. All CALABASH maximum values were within the range of the values measured at the non-operational areas. Therefore, these results support the process knowledge, Contaminated Land Report survey data, and fly-over data. 


\subsubsection{CONCLUSION}

CALABASH was an underground detonation with associated post-test drilling operations. The detonation cavity is part of the UGTA Sub-Project. There were no releases due to the detonation itself, and elevated radiological readings recorded during post-test drilling are not indicative of a release to the surface soils. This is supported by process knowledge, 100-percent coverage fly-over survey data, focused measurements provided by the Contaminated Land Report survey data, and RIDP data. The demonstrated lack of radiological releases to the surface soils in the vicinity of CAS 02-23-02 leads to the conclusion that there is no credible exposure pathway that could cause an NTS worker to receive a dose greater than $25 \mathrm{mrem} / \mathrm{yr}$ at this CAS.

This CAS requires no additional controls under the FFACO. While not required to achieve FFACO closure under the DQOs developed for CAU 107, the site is posted under 10 CFR 835 as a URMA, thereby further ensuring that an NTS worker will not receive a dose greater than $25 \mathrm{mrem} / \mathrm{yr}$. Based on the information presented above, data are adequate to support a closure option of no further action. 


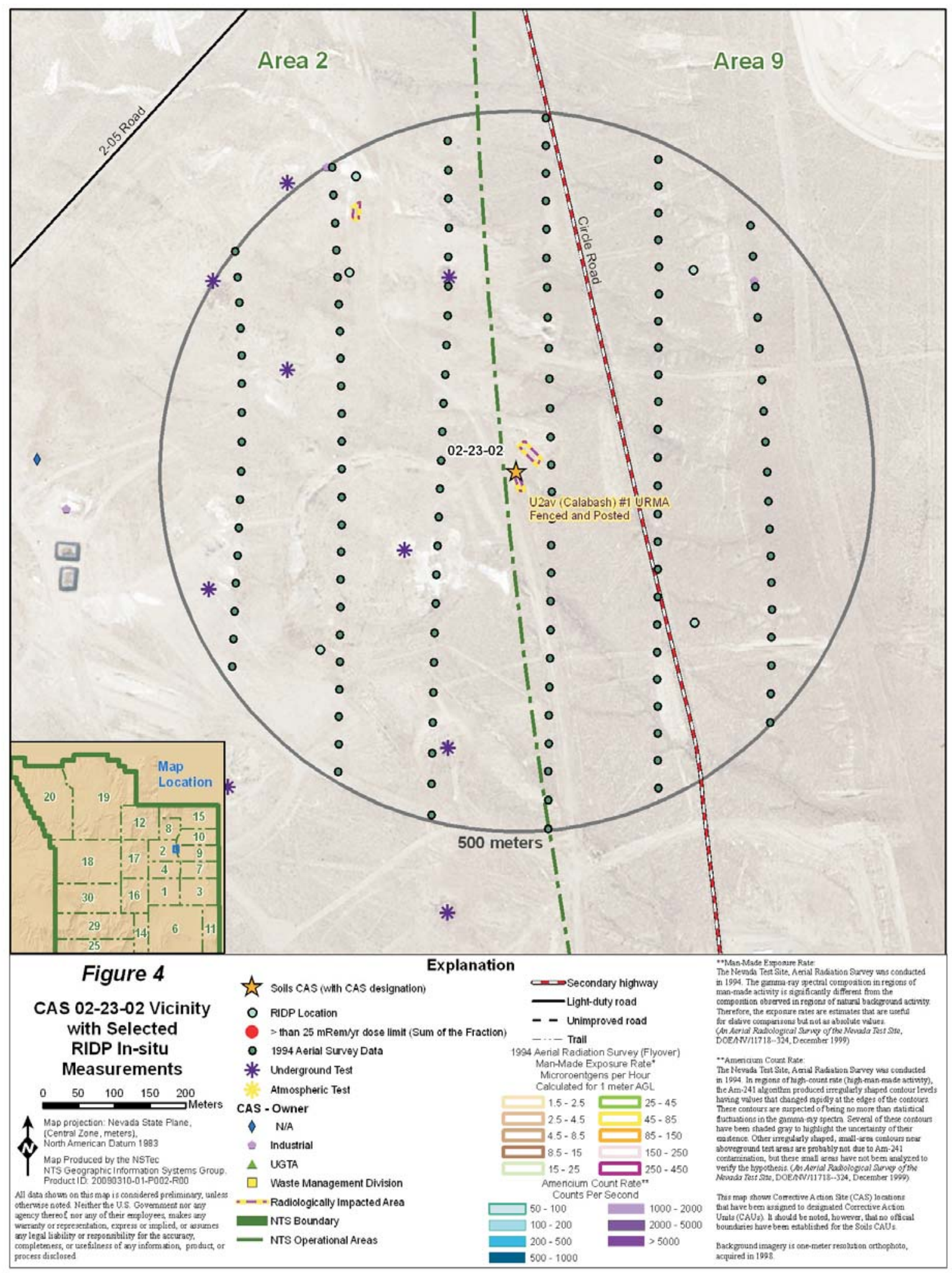

FIGURE 4 


\subsection{CAS 02-23-03, CONTAMINATED BERM}

CAS 02-23-03 was designated to address potential surface soil contamination associated with the FLASK-RED underground nuclear detonation. This CAS consists of a berm historically identified as radiologically contaminated. The berm is associated with a post-test cable pull. The FLASK-RED detonation did not form a subsidence crater. The area is a potential crater and no stability study has been completed, so both access and future land use are limited. The FLASK-RED detonation cavity is part of the UGTA Sub-Project. Field visits made to this CAS on January 18, 1995; February 9, 1995; and July 26, 2007, describe a berm extending west from U-2az\#3 with miscellaneous debris (e.g., metal) enclosed by a fence with radiological postings. Located at the east end of the fenced area is a concrete pad partially covered with pea gravel. The berm runs east to west for approximately $215 \mathrm{ft}$ and contains native soil and debris. At the west end of the fenced area is a smaller berm of soil. The area is posted as a URMA.

The FFACO location for the CAS is incorrect. The recommendation is made to update the FFACO coordinates of this CAS. This conclusion is supported by the coordinates given in REECo (1991), the U-2az\#3 emplacement hole coordinates (Raytheon Services Nevada [RSN], 1991), and the 2007 site visit.

\subsubsection{OPERATIONAL HISTORY}

The FLASK-RED detonation, conducted on May 26, 1970, was part of Operation Mandrel. The test, detonated in emplacement hole U-2az\#3, had a 35-ton yield (DOE/NV, 2000). A 1970 memorandum from LLNL indicates there was a problem with the instrument cable pull. It states, "Prior to covering the cable with backfill, spots with readings greater than $100 \mathrm{R} / \mathrm{hr}$ contact were detected." The diagram with this memorandum suggests the orientation of the berm is consistent with that of the cable (LLNL, 1970). No post-test drilling was conducted as part of the FLASK-RED operations (RSN, 1991). The cable was likely activated, not contaminated. It is impractical to sample the cable itself as it is inaccessible to workers and therefore cannot lead to an NTS worker dose greater than $25 \mathrm{mrem} / \mathrm{yr}$.

\subsubsection{RELEASE INFORMATION}

DOE/NV (1996) documented radiological releases from the detonation of FLASK-RED and from the subsequent cable pull. The cable was pulled from the emplacement hole immediately after the detonation and covered to limit test personnel exposures. It is currently covered by the berm. The release included xenon-133, xenon-133m, and xenon-135. These are gaseous radionuclides with short half-lives and are not suspected to be present in the soil. The longest half-life of these radionuclides is approximately 5 days (Nuclear Data Center, 2006). There was no post-test drilling at the site. There is no evidence of surface contamination at the site.

Additional evidence exists that the cable pull did not result in contaminant releases to the surface soils. A similar cable pull was conducted at Project 56 No. 4. This safety test resulted in an inadvertent fission event. A cable was pulled from the test hole, and exposure rates of 20 to $30 \mathrm{R} / \mathrm{hr}$ were recorded. An exposure rate of $50 \mathrm{R} / \mathrm{hr}$ was recorded $98 \mathrm{ft}$ from ground zero. Within an hour, significantly lower values, on the order of $10 \mathrm{R} / \mathrm{hr}$, were recorded. The rapid decrease in exposure rates may have been because the cable was activated, not contaminated (DNA, 1982). As the cable pull at FLASK-RED was comparable, the radioactivity associated with the FLASK-RED cable is unlikely to be released to the surface soils. 
Post-activity surveys did not detect alpha contamination at this site (REECo, 1973a). The lack of alpha contamination during test operations indicates that the cable pull operation did not bring subsurface contaminants to the surface soils.

All of the above information shows that a release to the surface soils around or under the FLASK-RED cable is unlikely.

\subsubsection{HISTORICAL CHARACTERIZATION INFORMATION}

The following data were used to evaluate the potential surface release for CAS 02-23-03 and determine the likelihood of a release to the surface soils in the area resulting from FLASK-RED.

\subsubsection{Fly-Over Data}

The fly-over survey performed in 1994 does not show detectable levels of radionuclides in the area of this CAS and does not identify any nearby areas as ROIs (Hendricks and Riedhauser, 1999). The fly-over survey process is well established and has been used at many sites to make the "yes-no" type of decision used in this SAFER Plan (NNSA/NSO, 2005). The fly-over data have been used in a semi-quantitative way to support the conclusion made based on operational history that a release to surface soils did not occur as a result of the FLASK-RED detonation or associated activities. There were 133 measurements collected within a 500-m radius of the FLASK-RED detonation (Figure 5). While the fly-over data, depicted in Figure 5, are shown as points, the field of view of the detector is large; thus, the fly-over survey provided 100-percent coverage of this area. These data were analyzed as described in Proctor (1997) and Hendricks and Riedhauser (1999). The results of the analyzed survey data are shown in Table 7. All measurements were less than the detection limit of the instrumentation.

TABle 7. CAS 02-23-03 Fly-OVER DATA SuMMARY

\begin{tabular}{||l|c|c|c||}
\hline MEASUREMENT TYPE & $\begin{array}{c}\text { NUMBER OF } \\
\text { MEASUREMENTS }\end{array}$ & $\begin{array}{c}\text { APPROXIMATE } \\
\text { DETECTION LIMIT }\end{array}$ & $\begin{array}{c}\text { NUMBER } \\
\text { MEASUREMENTS } \\
\text { >DETECTION LIMIT }\end{array}$ \\
\hline Total man-made & 133 & $1.5 \mathrm{microR} / \mathrm{hr}$ & 0 \\
\hline americium-241 & 133 & $50 \mathrm{cps}$ & 0 \\
\hline
\end{tabular}

The fly-over data presented above represent many individual measurements (referred to as point data), and each measurement is corrected for background radiation. The fly-over survey process continuously collects background radiation levels then corrects each measurement to remove it, resulting in data that show the added man-made radiation from testing or other activities. The fly-over measurements for total man-made radiation are very sensitive, with the detection limit of $1.5 \mathrm{microR} / \mathrm{hr}$. Typical background exposure rates are approximately $15 \mathrm{microR} / \mathrm{hr}$. Thus, the detection limit of $1.5 \mathrm{microR} / \mathrm{hr}$ results in detection of man-made radiation that is greater than approximately 10 percent of natural background radiation.

The fly-over surveys are very sensitive to americium-241. Americium-241 sensitivity is approximately $50 \mathrm{cps}$. A specific correlation to soil concentration values was not performed; however, a conservative correlation of $50 \mathrm{cps}$ to $300 \mathrm{nCi} / \mathrm{m}^{2}$ has been estimated by RSL based on other similar flights and the flight altitude of $200 \mathrm{ft}$. This value, $300 \mathrm{nCi} / \mathrm{m}^{2}$, was then compared to RIDP measurements made in non-operational areas of the NTS where no local releases of radioactive material occurred to determine whether the fly-over survey is capable of discerning levels of radioactivity indicative of a widespread radiological release. Since the RIDP values in the non-operational areas range from 24 to $573 \mathrm{nCi} / \mathrm{m}^{2}$ and the fly-over sensitivity is 
approximately $300 \mathrm{nCi} / \mathrm{m}^{2}$, this shows that the fly-over survey is capable of discerning where operational releases have occurred. No americium-241 fly-over survey measurements were greater than the detection limit, similar to the non-operational areas of the NTS. These data confirm that there was not a widespread release to surface soils.

\subsubsection{Contaminated Land Report Data}

Results of the surveys conducted in support of BN (2000) were used qualitatively to support the conclusions derived from the operational history. The surveys conducted for BN (2000) included radiological surveys in the immediate area of CAS 02-23-03. Measurements collected included exposure rates and FIDLER readings. Removable alpha and beta/gamma contamination were also assessed. Measurements were collected within the boundaries of URMAs and around the perimeter of these areas. Table 8 presents the results of these surveys (BN, 2000).

TABle 8. CAS 02-23-03 Contaminated LANd Survey DATa Summary

\begin{tabular}{||l|r|r|r|r|r|}
\hline $\begin{array}{c}\text { MEASUREMENT } \\
\text { TYPE }\end{array}$ & $\begin{array}{c}\text { NUMBER OF } \\
\text { MEASUREMENTS }\end{array}$ & $\begin{array}{c}\text { MAXIMUM } \\
\text { VALUE }\end{array}$ & $\begin{array}{c}\text { MINIMUM } \\
\text { VAlUE }\end{array}$ & $\begin{array}{c}\text { AVERAGE } \\
\text { VALUE }\end{array}$ & $\begin{array}{c}\text { APPROXIMATE } \\
\text { InSTRUMENT } \\
\text { SENSITIVITY }\end{array}$ \\
\hline Removable Alpha & 8 & $2 \mathrm{dpm} / 100 \mathrm{~cm}^{2}$ & $0 \mathrm{dpm} / 100 \mathrm{~cm}^{2}$ & $0.25 \mathrm{dpm} / 100 \mathrm{~cm}^{2}$ & $5 \mathrm{dpm} / 100 \mathrm{~cm}^{2}$ \\
\hline Removable Beta & 8 & $3 \mathrm{dpm} / 100 \mathrm{~cm}^{2}$ & $0 \mathrm{dpm} / 100 \mathrm{~cm}^{2}$ & $0.88 \mathrm{dpm} / 100 \mathrm{~cm}^{2}$ & $16 \mathrm{dpm} / 100 \mathrm{~cm}^{2}$ \\
\hline Exposure Rate & 8 & $20 \mathrm{uR} / \mathrm{hr}$ & $10 \mathrm{uR} / \mathrm{hr}$ & $16 \mathrm{uR} / \mathrm{hr}$ & $20 \mathrm{uR} / \mathrm{hr}^{1}$ \\
\hline FIDLER & 8 & $70 \mathrm{cps}$ & $60 \mathrm{cps}$ & $62 \mathrm{cps}$ & $100 \mathrm{cps}$ \\
\hline
\end{tabular}

${ }^{1}$ Approximate Instrument Sensitivity is estimated based on typical background values and instrument performance. All values reported below the instrument sensitivity are estimates only.

All values were below detection limits. These ground-based survey data consist of measurements that are focused in the post-test drilling areas in and around the URMAs, thereby augmenting the wide-area data collected via fly-over surveys. These data provide an additional resource indicating that post-test operations did not lead to surface soil contamination.

The NV/YMP RadCon Manual (NNSA/NSO, 2004b) is used at the NTS to implement the requirements set forth in 10 CFR 835 . The manual allows for the release of areas from radiological controls when certain radiological limits are met. The limits were established as acceptable levels for use by the general public and, thus, are conservative given the ongoing controls at CAS 02-23-03 and the lack of both public and worker access to the site. Table 9 outlines these release values. BN (2000) survey measurements in the area of CAS 02-23-03 are well below the radiological control limits outlined in Table 9.

\subsubsection{3 $\quad \underline{\text { RIDP Data }}$}

Several RIDP measurements were taken within $500 \mathrm{~m}$ of the FLASK-RED site (Figure 5). RIDP values were used to evaluate operational history and support the conclusion that the elevated exposure rate readings observed during the drilling operations did not indicate a widespread contaminant release. RIDP measurements taken within $500 \mathrm{~m}$ of the FLASK-RED site were evaluated against limits set forth in Anspaugh and Daniels (1995) as explained in Section 2.2.4.3 of this SAFER Plan. Table 10 provides the maximum, minimum, and average values of these data and compares the maximum value to the limits set forth in Anspaugh and Daniels (1995). All values are well below these limits. This evaluation is not intended as a formal dose assessment but as a means by which these data may be compared to evaluate the validity of the operational history release assumptions. 


\section{TAble 9. Surface Contamination Release VALUES ${ }^{1}$ IN DPM/100 CM$^{2}$}

\begin{tabular}{||l|l|l||}
\hline \multicolumn{1}{|c|}{ RADIONUCLIDE } & REMOVABLE $^{2,4}$ & $\begin{array}{c}\text { TOTAL (FIXED } \\
\text { +REMOVABLE) }\end{array}$ \\
\hline $\begin{array}{l}\text { natural uranium, uranium-235, uranium-238, and associated decay } \\
\text { products }\end{array}$ & $1,000^{7}$ & $5,000^{7}$ \\
\hline $\begin{array}{l}\text { transuranics, radium-226, radium-228, thorium-230, thorium-228, } \\
\text { protactinium-231, actinium-227, iodine-125, and iodine-129 }\end{array}$ & 20 & 500 \\
\hline $\begin{array}{l}\text { natural thorium, thorium-232, strontium-90, radium-223, radium-224, } \\
\text { uranium-232, iodine-126, iodine-131, and iodine-133 }\end{array}$ & 200 & 1,000 \\
\hline $\begin{array}{l}\text { beta-gamma emitters (nuclides with decay modes other than alpha } \\
\text { emission or spontaneous fission), except strontium-90 and others } \\
\text { noted above }\end{array}$ & 1,000 & 5,000 \\
\hline tritium and tritiated compounds $^{6}$ & 10,000 & N/A \\
\hline
\end{tabular}

1 The values in this table, with the exception noted in footnote 5, apply to radioactive contamination deposited on, but not incorporated into the interior or matrix of, the contaminated item. Where surface contamination by both alpha- and beta-gamma-emitting nuclides exists, the limits established for alpha- and beta-gamma-emitting nuclides apply independently.

2 As used in this table, dpm (disintegrations per minute) means the rate of emission by radioactive material as determined by correcting the counts per minute observed by an appropriate detector for background, efficiency, and geometric factors associated with the instrumentation.

3 The levels may be averaged over 1 square meter provided the maximum surface activity in any area of $100 \mathrm{~cm}^{2}$ is less than three times the value specified. For purposes of averaging, any square meter of surface shall be considered to be above the surface contamination value if: (1) From measurements of a representative number of sections it is determined that the average contamination level exceeds the applicable value; or (2) it is determined that the sum of the activity of all isolated spots or particles in any $100 \mathrm{~cm}^{2}$ area exceeds three times the applicable value.

4 The amount of removable radioactive material per $100 \mathrm{~cm}^{2}$ of surface area should be determined by swiping the area with dry filter or soft absorbent paper, applying moderate pressure, and then assessing the amount of radioactive material on the swipe with an appropriate instrument of known efficiency. (Note: The use of dry material may not be appropriate for tritium.) When removable contamination on objects of surface area less than $100 \mathrm{~cm}^{2}$ is determined, the activity per unit area shall be based on the actual area and the entire surface shall be wiped. It is not necessary to use swiping techniques to measure removable contamination levels if direct scan surveys indicate that the total residual surface contamination levels are within the limits for removable contamination.

5 This category of radionuclides includes mixed fission products, including the strontium-90 present in them. It does not apply to strontium-90 which has been separated from the other fission products or mixtures where the strontium-90 has been enriched.

6 Tritium contamination may diffuse into the volume or matrix of materials. Evaluation of surface contamination shall consider the extent to which such contamination may migrate to the surface in order to ensure the surface contamination value provided in this appendix is not exceeded. Once this contamination migrates to the surface, it may be removable, not fixed; therefore, a "Total" value does not apply.

7 (alpha)

TABLE 10. CAS 02-23-03 RIDP DATA SUMMARY

\begin{tabular}{|l|r|r|r|r|r||}
\hline RADIONUCLIDE & $\begin{array}{c}\text { NUMBER OF } \\
\text { MEASUREMENTS }\end{array}$ & $\begin{array}{c}\text { MAXIMUM } \\
\text { VALUE } \\
\left(\mathrm{nCi} / \mathrm{m}^{2}\right)\end{array}$ & $\begin{array}{c}\text { MINIMUM } \\
\text { VALUE } \\
\left(\mathrm{nCi} / \mathrm{m}^{2}\right)\end{array}$ & $\begin{array}{c}\text { AVERAGE } \\
\text { VALUE } \\
\left(\mathrm{nCi}^{2}\right)\end{array}$ & $\begin{array}{l}\text { MAX VALUE } \\
\text { FRACTION OF } \\
\text { DCG }\end{array}$ \\
\hline americium-241 & 2 & 45.11 & 35.80 & 40.45 & 0.02 \\
\hline barium-133 & 2 & 5.89 & 4.61 & 5.25 & 0.00 \\
\hline cobalt-60 & 2 & 0.87 & 0.60 & 0.73 & 0.00 \\
\hline cesium-137 & 2 & 263.70 & 13.13 & 138.42 & 0.08 \\
\hline europium-152 & 2 & 15.92 & 12.98 & 14.45 & 0.01 \\
\hline europium -154 & 2 & 12.64 & 11.42 & 12.03 & 0.01 \\
\hline europium -155 & 2 & 1.00 & 0.80 & 0.90 & 0.00 \\
\hline plutonium-238 & 2 & 66.90 & 16.15 & 18.25 & 0.01 \\
\hline plutonium -239 & 2 & 302.92 & 801.36 & 905.56 & 0.06 \\
\hline strontium-90 & 2 & 487.95 & 24.29 & 256.12 & 0.00 \\
\hline
\end{tabular}

Results for radionuclides measured by RIDP in the FLASK-RED vicinity and at the non-operational areas where releases did not occur were compared. All FLASK-RED maximum values were within the range of the values measured at the non-operational areas. Therefore, these results support the process knowledge, Contaminated Land Report survey data, and fly-over data. 


\subsubsection{CONCLUSION}

FLASK-RED was an underground detonation with associated post-test cable pull operations. The detonation cavity is part of the UGTA Sub-Project. Releases of gaseous radionuclides occurred as a result of both the detonation and the post-test cable pull. The cable was likely activated; however, the release and the cable pull are not indicative of a release to the surface soils. This is supported by process knowledge, 100-percent coverage fly-over survey data, focused measurements provided by the Contaminated Land Report survey data, and RIDP data. The demonstrated lack of radiological releases to the surface soils in the vicinity of CAS 02-23-03 leads to the conclusion that there is no credible exposure pathway that could cause an NTS worker to receive a dose greater than $25 \mathrm{mrem} / \mathrm{yr}$ at this CAS.

This CAS requires no additional controls under the FFACO. While not required to achieve FFACO closure under the DQOs developed for CAU 107, the site is posted under 10 CFR 835 as a URMA, thereby further ensuring that an NTS worker will not receive a dose greater than $25 \mathrm{mrem} / \mathrm{yr}$. Based on the information presented above, data are adequate to support a closure option of no further action. 


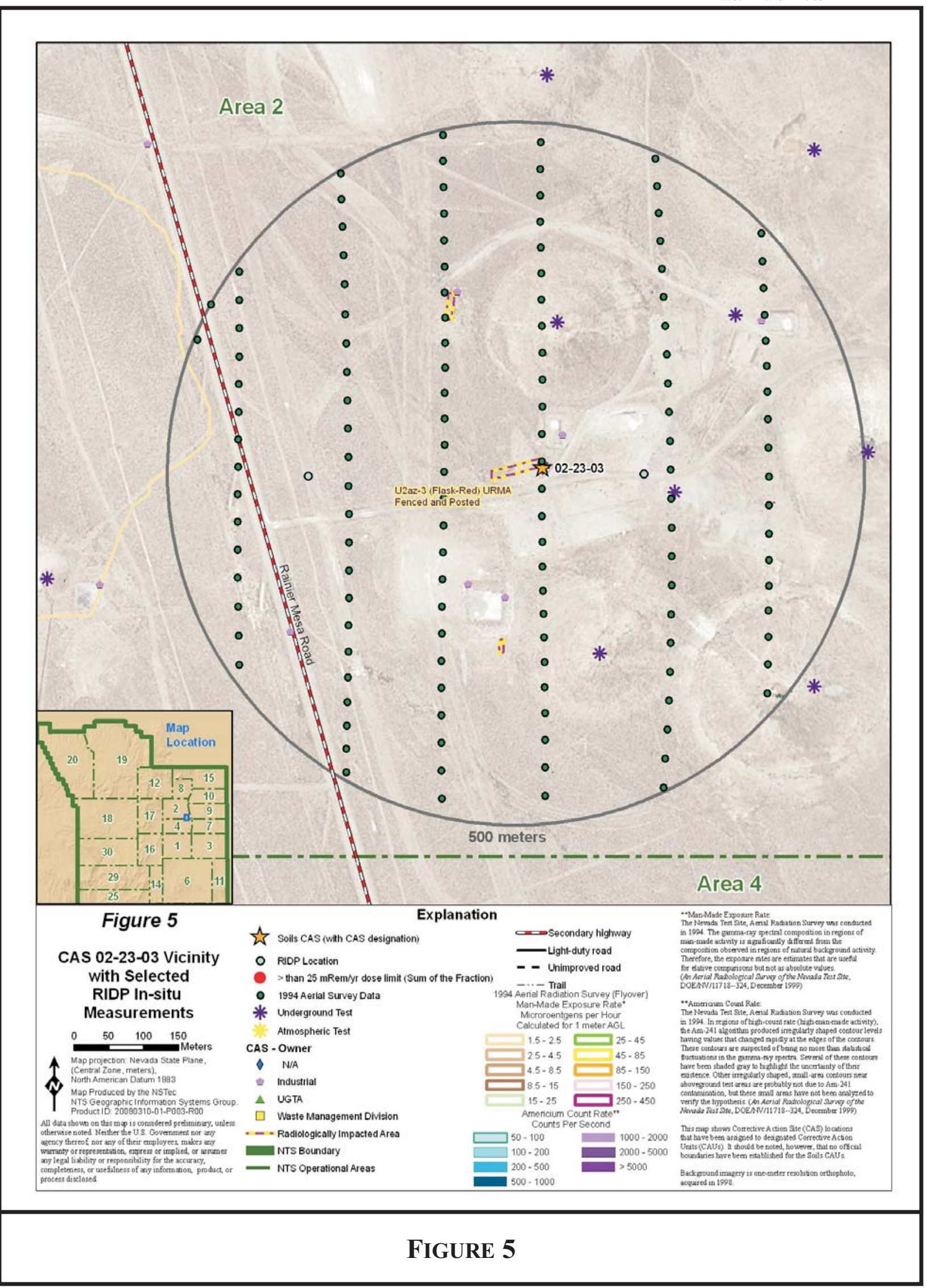




\subsection{CAS 02-23-10, Gourd-Amber Contamination Area}

CAS 02-23-10 was designated to address potential surface soil contamination associated with post-test drilling at the location of the GOURD-AMBER underground nuclear detonation (REECo, 1973a). REECo (1991) does not provide information about this site. The GOURD-AMBER detonation did not form a subsidence crater. The area is a potential crater and no stability study has been completed, so both access and future land use are limited. The GOURD-AMBER detonation cavity is part of the UGTA Sub-Project. Postings under 10 CFR 835 are not required at this site.

\subsubsection{OPERATIONAL HISTORY}

The GOURD-AMBER detonation, conducted on April 24, 1969, was part of Operation Bowline. The test, detonated in emplacement hole U2bf, had a yield of less than $20 \mathrm{kt}$ (DOE/NV, 2000). Stationary radiation monitors were placed in an arc around the surface ground zero of the test. No readings above background levels were detected by these monitors. Post-test drilling was conducted at hole PS\#1A. The maximum gamma exposure rate measured during post-test drilling operations at hole PS\#1A was $0.1 \mathrm{mR} / \mathrm{hr}$. No alpha contamination was detected (REECo, 1973a).

\subsubsection{RELEASE INFORMATION}

There was not a surface radiological release from the GOURD-AMBER detonation (DOE/NV, 1996). Slightly elevated exposure rate readings were noted during post-test drilling operations at hole PS\#1A (REECo, 1973a). Operational history indicates this type of elevated reading was typical of post-test drilling and sampling operations and is not a unique indicator of surface radiological contamination. The post-test holes were drilled in order to collect radiological samples; therefore, elevated readings were often observed from the release of gaseous radionuclides or elevated radioactivity emanating from within the sample container. DOE/NV (1996) does not document a radiological release from this detonation; thus, it is concluded that elevated exposure rate measurements were due to the contained sample material and not soil contamination or other surface release.

\subsubsection{HistoricAL CHARACTERIZATION INFORMATION}

The following data were used to evaluate the potential surface release for CAS 02-23-10 and determine the likelihood of a release to surface soils in the area resulting from GOURD-AMBER.

\subsubsection{Fly-Over Data}

The fly-over survey performed in 1994 shows low levels of detectable radioactivity (Hendricks and Riedhauser, 1999). The GOURD-AMBER CAS is on the perimeter of the SEDAN ROI, on the edge of contaminant extent from the SEDAN test (CAS 10-45-01). Thus, the low levels of radiological contamination detected in this area are not attributable to the GOURD-AMBER detonation but are related to the contamination extent of CAS 10-45-01, which will be addressed with a future CAU closure.

The fly-over survey process is well established and has been used at many sites to make the "yes-no" type of decision used in this SAFER Plan (NNSA/NSO, 2005). The fly-over data have 
been used in a semi-quantitative way to support the conclusion made based on operational history that a release to surface soils did not occur as a result of GOURD-AMBER operations. There were 135 measurements collected within a 500-m radius of the surface ground zero of the GOURD-AMBER detonation (Figure 6). While the fly-over data, depicted in Figure 6, are shown as points, the field of view of the detector is large; thus, the fly-over survey provided 100-percent coverage of this area. These data were analyzed as described in Proctor (1997) and Hendricks and Riedhauser (1999). The results of this analysis are shown in Table 11.

All measurements for americium-241 were below the detection limit, and 70 measurements for total man-made radioactivity were greater than the detection limit. These measurements were made in the known, contiguous contaminant plume of SEDAN (CAS 10-45-01), and this area will be addressed with a future CAU closure. However, as shown in Section 2.6.3.3, these data are also below the dose limit.

TABLE 11. CAS 02-23-10 Fly-OVER DATA SuMmary

\begin{tabular}{|l|c|c|c|}
\hline MEASUREMENT TYPE & $\begin{array}{c}\text { NUMBER OF } \\
\text { MEASUREMENTS }\end{array}$ & $\begin{array}{c}\text { APPROXIMATE } \\
\text { DETECTION LIMIT }\end{array}$ & $\begin{array}{c}\text { NUMBER } \\
\text { MEASUREMENTS } \\
\text { >DETECTION LIMIT }\end{array}$ \\
\hline Total man-made & 135 & $1.5 \mathrm{microR} / \mathrm{hr}$ & 70 \\
\hline americium-241 & 135 & $50 \mathrm{cps}$ & 0 \\
\hline
\end{tabular}

The fly-over data presented above represent many individual measurements (referred to as point data), and each measurement is corrected for background radiation. The fly-over survey process continuously collects background radiation levels. Each gross measurement is then corrected to remove background radiation levels, resulting in data that show the added man-made radiation from testing or other activities. The fly-over measurements for total man-made radiation are very sensitive, with the detection limit of $1.5 \mathrm{microR} / \mathrm{hr}$. Typical background exposure rates are approximately $15 \mathrm{microR} / \mathrm{hr}$. Thus, the detection limit of $1.5 \mathrm{microR} / \mathrm{hr}$ results in detection of man-made radiation that is greater than approximately 10 percent of natural background radiation.

The fly-over surveys are very sensitive to americium-241. Americium-241 sensitivity is approximately $50 \mathrm{cps}$. A specific correlation to soil concentration values was not performed; however, a conservative correlation of $50 \mathrm{cps}$ to $300 \mathrm{nCi} / \mathrm{m}^{2}$ has been estimated by RSL based on other similar flights and the flight altitude of $200 \mathrm{ft}$. This value, $300 \mathrm{nCi} / \mathrm{m}^{2}$, was then compared to RIDP measurements made in non-operational areas of the NTS where no local releases of radioactive material occurred to determine whether the fly-over survey is capable of discerning levels of radioactivity indicative of a widespread radiological release. Since the RIDP values in the non-operational areas range from 24 to $573 \mathrm{nCi} / \mathrm{m}^{2}$ and the fly-over sensitivity is approximately $300 \mathrm{nCi} / \mathrm{m}^{2}$, this shows that the fly-over survey is capable of discerning where operational releases have occurred. No americium-241 fly-over survey measurements were greater than the detection limit, similar to the non-operational areas of the NTS. These data confirm that there was not a widespread release to surface soils.

\subsubsection{Contaminated Land Report Data}

Radiological surveys conducted for BN (2000) did not include this CAS location because radiological contamination was not suspected in the area. The area is not controlled for radiological purposes. 


\subsubsection{3 $\quad$ RIDP Data}

Several RIDP measurements were taken within $500 \mathrm{~m}$ of the GOURD-AMBER site (DRI, 2007) (Figure 6). RIDP values were used to evaluate operational history and support the conclusion that the GOURD-AMBER detonation did not lead to a widespread contaminant release to surface soils. RIDP measurements taken within $500 \mathrm{~m}$ of the GOURD-AMBER site were evaluated against limits set forth in Anspaugh and Daniels (1995) as explained in Section 2.2.4.3 of this SAFER Plan. Table 12 provides the maximum, minimum, and average values of these data and compares the maximum value to the limits set forth in Anspaugh and Daniels (1995). All values are well below these limits. This evaluation is not intended as a formal dose assessment but as a means by which these data may be compared to evaluate the validity of the operational history release assumptions.

Results for radionuclides measured by RIDP in the GOURD-AMBER vicinity and at the non-operational areas where releases did not occur were compared. All GOURD-AMBER maximum values were within the range of the values measured at the non-operational areas. Therefore, these results support the process knowledge and fly-over data.

TABLE 12. CAS 02-23-10 RIDP DATA SUMMARY

\begin{tabular}{|l|r|r|r|r|r||}
\hline RADIONUCLIDE & $\begin{array}{c}\text { NUMBER OF } \\
\text { MEASUREMENTS }\end{array}$ & $\begin{array}{c}\text { MAXIMUM } \\
\text { VALUE } \\
\left(\mathrm{nCi} / \mathrm{m}^{2}\right)\end{array}$ & $\begin{array}{c}\text { MINIMUM } \\
\text { VALUE } \\
\left(\mathrm{nCi} / \mathrm{m}^{2}\right)\end{array}$ & $\begin{array}{c}\text { AvERAGE } \\
\text { VALUE } \\
\left(\mathrm{nCi} / \mathrm{m}^{2}\right)\end{array}$ & $\begin{array}{c}\text { MAX VALUE } \\
\text { FRACTION OF } \\
\text { DCG }\end{array}$ \\
\hline americium-241 & 4 & 64.43 & 47.82 & 55.35 & 0.03 \\
\hline cobalt-60 & 4 & 0.68 & 0.52 & 0.59 & 0.00 \\
\hline cesium-134 & 4 & 0.00 & 0.00 & 0.00 & 0.00 \\
\hline cesium-137 & 4 & 240.60 & 62.38 & 155.83 & 0.07 \\
\hline europium-152 & 4 & 18.14 & 14.89 & 16.43 & 0.01 \\
\hline europium-154 & 4 & 14.79 & 10.60 & 12.69 & 0.01 \\
\hline europium-155 & 4 & 1.44 & 0.95 & 1.23 & 0.00 \\
\hline lutetium-174 & 4 & 0.29 & 0.00 & 0.20 & 0.00 \\
\hline plutonium-238 & 4 & 54.76 & 28.04 & 43.90 & 0.01 \\
\hline plutonium-239 & 4 & 369.05 & 194.27 & 297.15 & 0.07 \\
\hline rhodium-101 & 4 & 0.11 & 0.00 & 0.08 & 0.00 \\
\hline ruthenium-106 & 4 & 0.00 & 0.00 & 0.00 & 0.00 \\
\hline antimony-125 & 4 & 0.10 & 0.08 & 0.08 & 0.00 \\
\hline strontium-90 & 4 & 166.20 & 49.81 & 91.04 & 0.00 \\
\hline \hline
\end{tabular}

\subsubsection{CONCLUSION}

GOURD-AMBER was an underground detonation with associated post-test drilling operations. The detonation cavity is part of the UGTA Sub-Project. The low levels of contamination present near the site are not attributable to the GOURD-AMBER detonation but are associated with the SEDAN detonation, which will be addressed with a future CAU closure (Figure 7). There were no releases due to the detonation itself, and elevated radiological readings recorded during posttest drilling are not indicative of a release to the surface soils. This is supported by process knowledge, 100-percent coverage fly-over survey data, and RIDP data. The demonstrated lack of radiological releases to the surface soils related to CAS 02-23-10 leads to the conclusion that there is no credible exposure pathway that could cause an NTS worker to receive a dose greater than $25 \mathrm{mrem} / \mathrm{yr}$ at this CAS.

This CAS requires no additional controls under the FFACO. Based on the information presented above, data are adequate to support a closure option of no further action. 


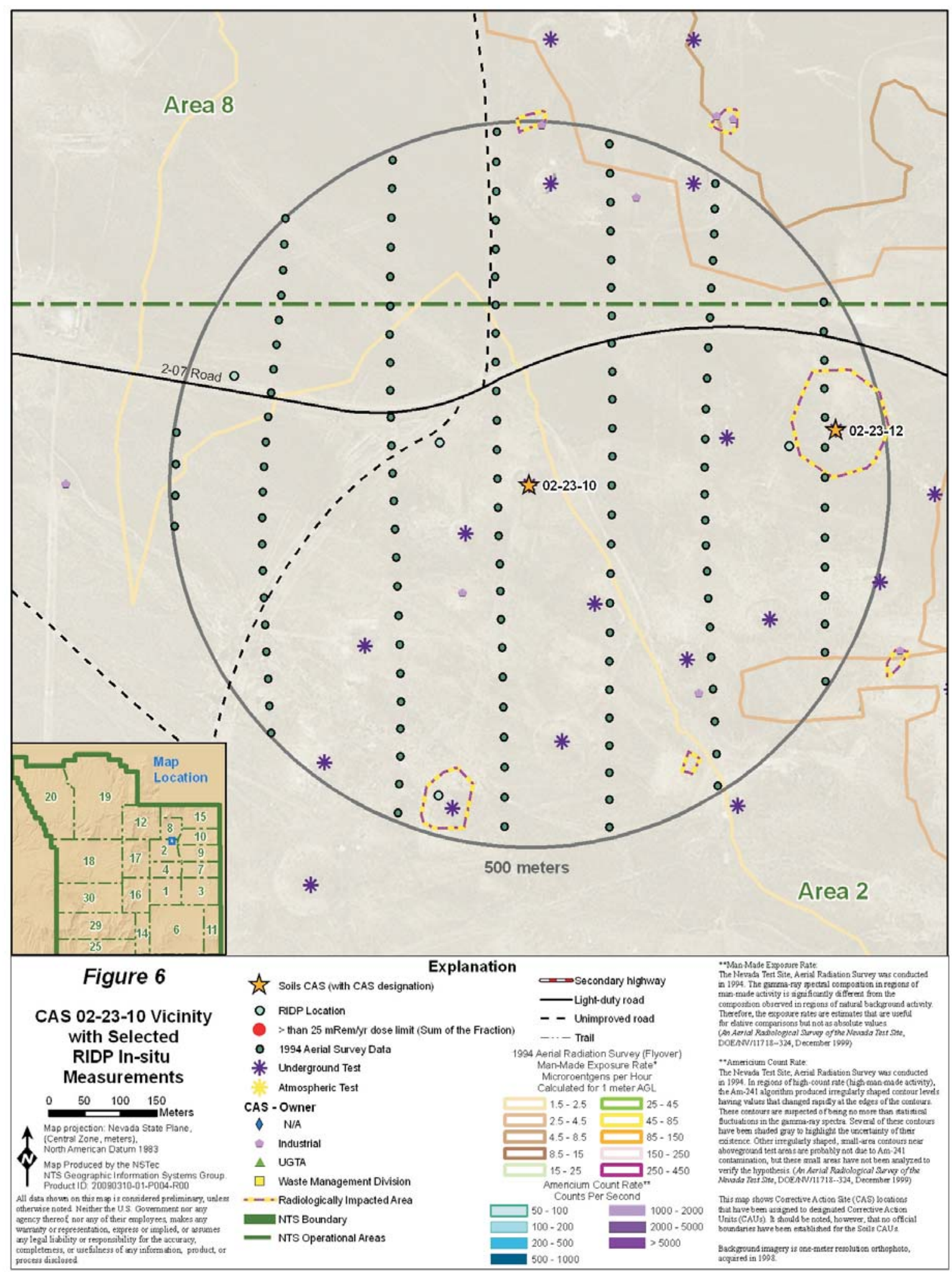

FIGURE 6 


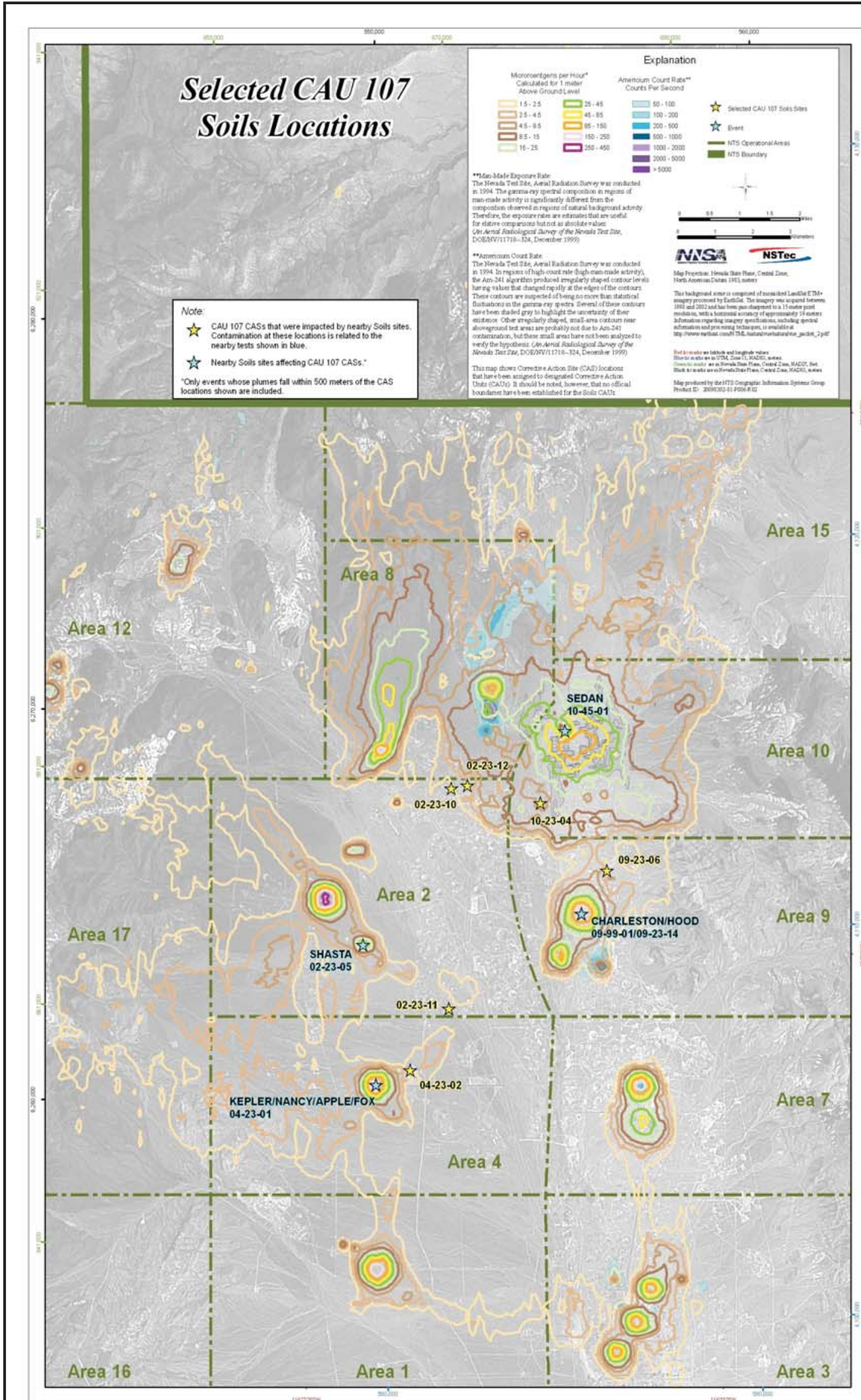

Figure 7. CAU 107 CASs With CONTAMination AtTributable to Nearby Detonations 
THIS PAGE INTENTIONALLY LEFT BLANK 


\subsection{CAS 02-23-11, SAPPHO CONTAMINATION AREA}

CAS 02-23-11 was designated to address potential surface soil contamination associated with post-test drilling at the location of the SAPPHO underground nuclear detonation (REECo, 1973a). REECo (1991) does not provide information about this site. The area is a potential subsidence crater and no stability study has been completed, so both access and future land use are limited. The SAPPHO detonation cavity is part of the UGTA Sub-Project. This area is posted as a URMA, likely due to the deep underground source term that resulted from the nuclear test (Johnston, 2007).

\subsubsection{OPERATIONAL HiSTORY}

The SAPPHO test, conducted on March 23, 1972, was part of Operation Grommet. The test, detonated in emplacement hole U2dh2, had a yield of less than $20 \mathrm{kt}$ (DOE/NV, 2000). A re-entry survey was conducted after the test and measured background levels of radioactivity. Post-test drilling was conducted at hole PS\#1A. The maximum gamma exposure rate measured during post-test drilling operations at hole PS\#1A was $3 \mathrm{mR} / \mathrm{hr}$. No alpha contamination was detected (REECo, 1973b).

\subsubsection{RELEASE INFORMATION}

DOE/NV (1996) documented radiological releases resulting from the post-test drilling operations at hole PS\#1A. The releases included xenon-133 and xenon-133m. These are gaseous radionuclides with short half-lives and are not suspected to be present in the soil. The longest half-life of these radionuclides is approximately 5 days (Nuclear Data Center, 2006). Elevated exposure rate readings were noted during post-test drilling operations at hole PS\#1A (REECo, 1973b). Operational history indicates this type of elevated reading was typical of post-test drilling and sampling operations and is not a unique indicator of surface radiological contamination. The post-test holes were drilled in order to collect radiological samples; therefore, elevated readings were often observed from the release of gaseous radionuclides or elevated radioactivity emanating from within the sample container. In either case, this information shows that a radiological release to surface soils did not occur.

\subsubsection{Historical CHARACTERIZATION INFORMATION}

The following data were used to evaluate the potential surface release for CAS 02-23-11 and determine the likelihood of a release to surface soils in the area resulting from SAPPHO.

\subsubsection{Fly-Over Data}

The fly-over survey performed in 1994 shows low levels of detectable radioactivity (Hendricks and Riedhauser, 1999). The SAPPHO CAS location is on the edge of contaminant extent from the SHASTA test (CAS 02-23-05). Thus, the low levels of radiological contamination detected in this area are not attributable to the SAPPHO detonation but are related to the contamination extent of CAS 02-23-05, which will be addressed with a future CAU closure.

The fly-over survey process is well established and has been used at many sites to make the "yes-no" type of decision used in this SAFER Plan (NNSA/NSO, 2005). The fly-over data have been used in a semi-quantitative way to support the conclusion made based on operational history that a release to surface soils did not occur as a result of the SAPPHO detonation or associated activities. There were 126 measurements collected within a 500-m radius of the 
SAPPHO detonation (Figure 8). While the fly-over data, depicted in Figure 8, are shown as points, the field of view of the detector is large; thus, the fly-over survey provided 100-percent coverage of this area. These data were analyzed as described in Proctor (1997) and Hendricks and Riedhauser (1999). The results of the analyzed survey data are shown in Table 13.

All measurements for americium-241 were below the detection limit, and 20 measurements for total man-made radioactivity were greater than the detection limit. These measurements were made in the known contaminant plume of CAS 02-23-05, and this area will be addressed with a future CAU closure. However, as shown in Section 2.7.3.3, these data are also below the dose limit.

TABLE 13. CAS 02-23-11 Fly-OVER DATA SUMMARY

\begin{tabular}{|l|c|c|c|}
\hline MEASUREMENT TYPE & $\begin{array}{c}\text { NUMBER OF } \\
\text { MEASUREMENTS }\end{array}$ & $\begin{array}{c}\text { APPROXIMATE } \\
\text { DETECTION LIMIT }\end{array}$ & $\begin{array}{c}\text { NUMBER } \\
\text { MEASUREMENTS } \\
\text { >DETECTION LIMIT }\end{array}$ \\
\hline Total man-made & 126 & $1.5 \mathrm{microR} / \mathrm{hr}$ & 20 \\
\hline americium-241 & 126 & $50 \mathrm{cps}$ & 0 \\
\hline
\end{tabular}

The fly-over data presented above represent many individual measurements (referred to as point data), and each measurement is corrected for background radiation. The fly-over survey process continuously collects background radiation levels then corrects each measurement to remove it, resulting in data that show the added man-made radiation from testing or other activities. The fly-over measurements for total man-made radiation are very sensitive, with the detection limit of $1.5 \mathrm{microR} / \mathrm{hr}$. Typical background exposure rates are approximately $15 \mathrm{microR} / \mathrm{hr}$. Thus, the detection limit of $1.5 \mathrm{microR} / \mathrm{hr}$ results in detection of man-made radiation that is greater than approximately 10 percent of natural background radiation.

The fly-over surveys are very sensitive to americium-241. Americium-241 sensitivity is approximately $50 \mathrm{cps}$. A specific correlation to soil concentration values was not performed; however, a conservative correlation of $50 \mathrm{cps}$ to $300 \mathrm{nCi} / \mathrm{m}^{2}$ has been estimated by RSL based on other similar flights and the flight altitude of $200 \mathrm{ft}$. This value, $300 \mathrm{nCi} / \mathrm{m}^{2}$, was then compared to RIDP measurements made in non-operational areas of the NTS where no local releases of radioactive material occurred to determine whether the fly-over survey is capable of discerning levels of radioactivity indicative of a widespread radiological release. Since the RIDP values in the non-operational areas range from 24 to $573 \mathrm{nCi} / \mathrm{m}^{2}$ and the fly-over sensitivity is approximately $300 \mathrm{nCi} / \mathrm{m}^{2}$, this shows that the fly-over survey is capable of discerning where operational releases have occurred. No americium-241 fly-over survey measurements were greater than the detection limit, similar to the non-operational areas of the NTS. These data confirm that there was not a widespread release to surface soils.

\subsubsection{Contaminated Land Report Data}

Results of the surveys conducted in support of BN (2000) were used qualitatively to support the conclusions derived from the operational history. The surveys conducted for BN (2000) included radiological surveys in the immediate area of CAS 02-23-11. Measurements collected included exposure rates and FIDLER readings. Removable alpha and beta/gamma contamination were also assessed. Measurements were collected within the boundaries of URMAs and around the perimeter of these areas. Table 14 presents the results of these surveys (BN, 2000). 
TABle 14. CAS 02-23-11 Contaminated LAND SuRvey DATA Summary

\begin{tabular}{||l|r|r|r|r|r||}
\hline $\begin{array}{c}\text { MEASUREMENT } \\
\text { TYPE }\end{array}$ & $\begin{array}{c}\text { NuMBER OF } \\
\text { MEASUREMENTS }\end{array}$ & $\begin{array}{c}\text { MAXIMUM } \\
\text { VALUE }\end{array}$ & $\begin{array}{c}\text { MINIMUM } \\
\text { VALUE }\end{array}$ & $\begin{array}{c}\text { AVERAGE } \\
\text { VALUE }\end{array}$ & $\begin{array}{c}\text { APPROXIMATE } \\
\text { InSTRUMENT } \\
\text { SENSITIVITY }\end{array}$ \\
\hline Removable Alpha & 13 & $2 \mathrm{dpm} / 100 \mathrm{~cm}^{2}$ & $0 \mathrm{dpm} / 100 \mathrm{~cm}^{2}$ & $0.23 \mathrm{dpm} / 100 \mathrm{~cm}^{2}$ & $5 \mathrm{dpm} / 100 \mathrm{~cm}^{2}$ \\
\hline Removable Beta & 13 & $10 \mathrm{dpm} / 100 \mathrm{~cm}^{2}$ & $0 \mathrm{dpm} / 100 \mathrm{~cm}^{2}$ & $1.2 \mathrm{dpm} / 100 \mathrm{~cm}^{2}$ & $16 \mathrm{dpm} / 100 \mathrm{~cm}^{2}$ \\
\hline Exposure Rate & 13 & $15 \mathrm{uR} / \mathrm{hr}$ & $10 \mathrm{uR} / \mathrm{hr}$ & $12 \mathrm{uR} / \mathrm{hr}$ & $20 \mathrm{uR} / \mathrm{hr}^{1}$ \\
\hline FIDLER & 13 & $75 \mathrm{cps}$ & $40 \mathrm{cps}$ & $63 \mathrm{cps}$ & $100 \mathrm{cps}$ \\
\hline
\end{tabular}

${ }^{1}$ Approximate Instrument Sensitivity is estimated based on typical background values and instrument performance. All values reported below the instrument sensitivity are estimates only.

All values were below detection limits. These ground-based survey data consist of measurements that are focused in the post-test drilling areas in and around the URMAs, thereby augmenting the wide-area data collected via fly-over surveys. These data provide an additional resource indicating that post-test drilling operations did not lead to surface soil contamination.

The NV/YMP RadCon Manual (NNSA/NSO, 2004b) is used at the NTS to implement the requirements set forth in 10 CFR 835 . The manual allows for the release of areas from radiological controls when certain radiological limits are met. The limits were established as acceptable levels for use by the general public and, thus, are conservative given the ongoing controls at CAS 02-23-11 and the lack of both public and worker access to the site. Table 15 outlines these release values. BN (2000) survey measurements in the area of CAS 02-23-11 are well below the radiological control limits outlined in Table 15.

\subsubsection{3 $\quad \underline{\text { RIDP Data }}$}

Several RIDP measurements were taken within $500 \mathrm{~m}$ of the SAPPHO site (Figure 8). RIDP values were used to evaluate operational history and support the conclusion that the elevated exposure rate readings observed during the drilling operations did not indicate a widespread contaminant release. RIDP measurements taken within $500 \mathrm{~m}$ of the SAPPHO site were evaluated against limits set forth in Anspaugh and Daniels (1995) as explained in Section 2.2.4.3 of this SAFER Plan. Table 16 provides the maximum, minimum, and average values of these data and compares the maximum value to the limits set forth in Anspaugh and Daniels (1995). All values are well below these limits. This evaluation is not intended as a formal dose assessment but as a means by which these data may be compared to evaluate the validity of the operational history release assumptions.

Results for radionuclides measured by RIDP in the SAPPHO vicinity and at the non-operational areas where releases did not occur were compared. The slightly elevated RIDP measurement was collected within the known contaminant plume of CAS 02-23-05 and is consistent with the operational history. Therefore, these results support the process knowledge, Contaminated Land Report survey data, and fly-over data. 
CAU 107 SAFER Plan

Section: Unit Description

Revision: 1

Date: March 2009

TABle 15. Surface CONTAMination Release VALUES ${ }^{1}$ IN DPM/100 CM$^{2}$

\begin{tabular}{||l|l|l||}
\hline \multicolumn{1}{|c|}{ RADIONUCLIDE } & REMOVABLE $^{2,4}$ & $\begin{array}{c}\text { TOTAL (FIXED } \\
\text { +REMOVABLE) }\end{array}$ \\
\hline $\begin{array}{l}\text { natural uranium, uranium-235, uranium-238, and associated decay } \\
\text { products }\end{array}$ & $1,000^{7}$ & $5,000^{7}$ \\
\hline $\begin{array}{l}\text { transuranics, radium-226, radium-228, thorium-230, thorium-228, } \\
\text { protactinium-231, actinium-227, iodine-125, and iodine-129 }\end{array}$ & 20 & 500 \\
\hline $\begin{array}{l}\text { natural thorium, thorium-232, strontium-90, radium-223, radium-224, } \\
\text { uranium-232, iodine-126, iodine-131, and iodine-133 }\end{array}$ & 200 & 1,000 \\
\hline $\begin{array}{l}\text { beta-gamma emitters (nuclides with decay modes other than alpha } \\
\text { emission or spontaneous fission), except strontium-90 and others } \\
\text { noted above }\end{array}$ & 1,000 & 5,000 \\
\hline tritium and tritiated compounds $^{6}$ & 10,000 & N/A \\
\hline
\end{tabular}

1 The values in this table, with the exception noted in footnote 5, apply to radioactive contamination deposited on, but not incorporated into the interior or matrix of, the contaminated item. Where surface contamination by both alpha- and beta-gamma-emitting nuclides exists, the limits established for alpha- and beta-gamma-emitting nuclides apply independently.

2 As used in this table, dpm (disintegrations per minute) means the rate of emission by radioactive material as determined by correcting the counts per minute observed by an appropriate detector for background, efficiency, and geometric factors associated with the instrumentation.

3 The levels may be averaged over 1 square meter provided the maximum surface activity in any area of $100 \mathrm{~cm}^{2}$ is less than three times the value specified. For purposes of averaging, any square meter of surface shall be considered to be above the surface contamination value if: (1) From measurements of a representative number of sections it is determined that the average contamination level exceeds the applicable value; or (2) it is determined that the sum of the activity of all isolated spots or particles in any $100 \mathrm{~cm}^{2}$ area exceeds three times the applicable value.

4 The amount of removable radioactive material per $100 \mathrm{~cm}^{2}$ of surface area should be determined by swiping the area with dry filter or soft absorbent paper, applying moderate pressure, and then assessing the amount of radioactive material on the swipe with an appropriate instrument of known efficiency. (Note: The use of dry material may not be appropriate for tritium.) When removable contamination on objects of surface area less than $100 \mathrm{~cm}^{2}$ is determined, the activity per unit area shall be based on the actual area and the entire surface shall be wiped. It is not necessary to use swiping techniques to measure removable contamination levels if direct scan surveys indicate that the total residual surface contamination levels are within the limits for removable contamination.

5 This category of radionuclides includes mixed fission products, including the strontium-90 present in them. It does not apply to strontium-90 which has been separated from the other fission products or mixtures where the strontium-90 has been enriched.

6 Tritium contamination may diffuse into the volume or matrix of materials. Evaluation of surface contamination shall consider the extent to which such contamination may migrate to the surface in order to ensure the surface contamination value provided in this appendix is not exceeded. Once this contamination migrates to the surface, it may be removable, not fixed; therefore, a "Total" value does not apply.

7 (alpha)

TABLE 16. CAS 02-23-11 RIDP DATA SUMMARY

\begin{tabular}{|l|r|r|r|r|r||}
\hline RADIONUCLIDE & $\begin{array}{c}\text { NUMBER OF } \\
\text { MEASUREMENTS }\end{array}$ & $\begin{array}{c}\text { MAXIMUM } \\
\text { VALUE } \\
\left(\mathrm{nCi} / \mathrm{m}^{2}\right)\end{array}$ & $\begin{array}{c}\text { MINIMUM } \\
\text { VALUE } \\
\left(\mathrm{nCi} / \mathrm{m}^{2}\right)\end{array}$ & $\begin{array}{c}\text { AVERAGE } \\
\text { VALUE } \\
\left(\mathrm{nCi} / \mathrm{m}^{2}\right)\end{array}$ & $\begin{array}{l}\text { MAX VALUE } \\
\text { FRACTION OF } \\
\text { DCG }\end{array}$ \\
\hline americium-241 & 3 & 44.44 & 39.92 & 41.52 & 0.02 \\
\hline barium-133 & 3 & 4.63 & 0.00 & 1.54 & 0.00 \\
\hline cobalt-60 & 3 & 1.23 & 0.50 & 0.80 & 0.00 \\
\hline cesium-137 & 3 & 405.12 & 84.19 & 218.56 & 0.12 \\
\hline europium-152 & 3 & 14.59 & 12.25 & 13.49 & 0.01 \\
\hline europium -154 & 3 & 12.91 & 8.64 & 10.51 & 0.01 \\
\hline europium -155 & 3 & 0.88 & 0.75 & 0.83 & 0.00 \\
\hline plutonium-238 & 3 & 112.96 & 18.14 & 66.24 & 0.02 \\
\hline plutonium -239 & 3 & 347.44 & 248.40 & 33.54 & 0.07 \\
\hline strontium-90 & 3 & 1025.03 & 155.78 & 463.77 & 0.01 \\
\hline
\end{tabular}




\subsubsection{CONCLUSION}

SAPPHO was an underground detonation with associated post-test drilling operations. The detonation cavity is part of the UGTA Sub-Project. The very low levels of contamination present near the site are not attributable to the SAPPHO detonation but are associated with the SHASTA detonation, which will be addressed with a future CAU closure (Figure 7). There were no releases due to the detonation itself, and elevated radiological readings recorded during posttest drilling are not indicative of a release to the surface soils. This is supported by process knowledge, 100-percent coverage fly-over survey data, focused measurements provided by the Contaminated Land Report survey data, and RIDP data. The demonstrated lack of radiological releases to the surface soils in the vicinity of CAS 02-23-11 leads to the conclusion that there is no credible exposure pathway that could cause an NTS worker to receive a dose greater than $25 \mathrm{mrem} / \mathrm{yr}$ at this CAS.

This CAS requires no additional controls under the FFACO. While not required to achieve FFACO closure under the DQOs developed for CAU 107, the site is posted under 10 CFR 835 as a URMA, thereby further ensuring that an NTS worker will not receive a dose greater than $25 \mathrm{mrem} / \mathrm{yr}$. Based on the information presented above, data are adequate to support a closure option of no further action. 


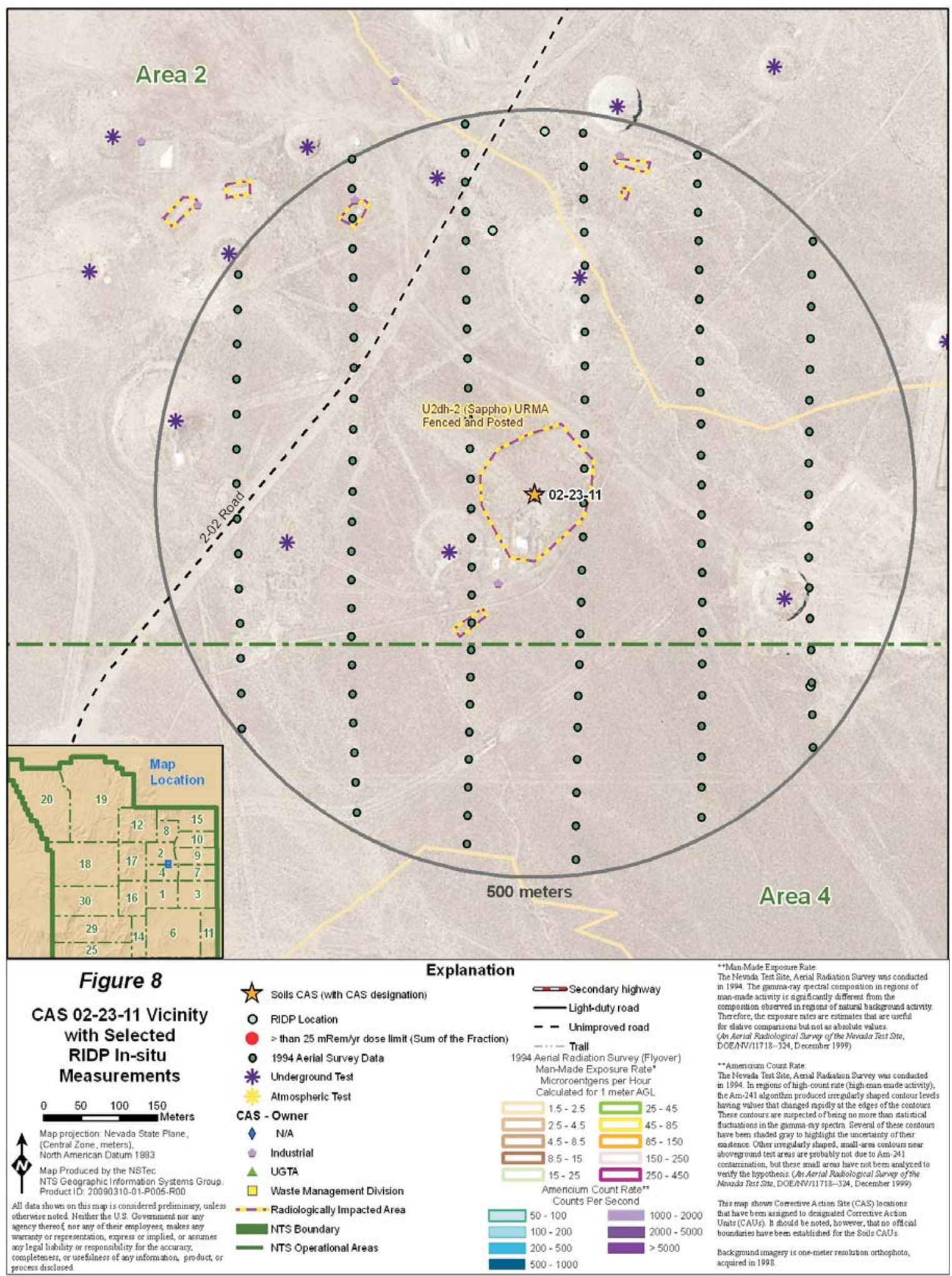

FIGURE 8 


\subsection{CAS 02-23-12, Scuttle Contamination AREa}

CAS 02-23-12 was designated to address potential surface soil contamination associated with the SCUTTLE underground nuclear detonation. This site was recently added to the FFACO because a radiological release during detonation of SCUTTLE was listed in DOE/NV (1996).

REECo (1991) does not provide information about this site. The area is a potential subsidence crater and no stability study has been completed, so both access and future land use are limited. The SCUTTLE detonation cavity is part of the UGTA Sub-Project. The area is a URMA, likely due to the deep underground source term that resulted from the nuclear test (Johnston, 2007).

\subsubsection{OPERATIONAL HiSTORY}

The SCUTTLE test, conducted on November 13, 1969, was part of Operation Mandrel. The test, detonated in emplacement hole U2bh, had a yield of $1.7 \mathrm{kt}$ (DOE/NV, 2000). Stationary radiation monitors were placed in an arc around the surface ground zero of the test. The maximum gamma exposure rate measured on perimeter monitors was $600 \mathrm{mR} / \mathrm{hr}$ and occurred 19 minutes after the SCUTTLE detonation. Approximately 3 hours later all these monitors recorded background levels of radioactivity. A re-entry survey was conducted after the test, and the maximum gamma exposure rate measured was $10 \mathrm{R} / \mathrm{hr}$. No alpha contamination was detected during the re-entry survey. The maximum gamma exposure rate measured during post-test operations was $1.5 \mathrm{mR} / \mathrm{hr}$. No alpha contamination was detected during post-test operations (REECo, 1973a).

\subsubsection{RELEASE INFORMATION}

DOE/NV (1996) documented radiological releases from the detonation of the SCUTTLE weapons test but not from post-test drilling activities. The release included rubidium-88, iodine-133, xenon-135, and cesium-138. These are gaseous and volatile radionuclides with short half-lives and are not suspected to be present in the soil. The longest half-life of these radionuclides is approximately 5 days (Nuclear Data Center, 2006). Elevated exposure rate readings were noted as a result of this release. Operational history indicates this type of elevated reading was typical when radiological releases occurred during detonation and is not a unique indicator of surface radiological contamination. Furthermore, the measurements taken by the perimeter radiation monitors measured a large decrease in radioactivity approximately 3 hours after the test. This indicates that the released material was dispersed quickly, decayed rapidly, and did not settle onto the surface soils in the area.

\subsubsection{Historical CHARACTERIZATION INFORMATION}

The following data were used to evaluate the potential surface release for CAS 02-23-12 and determine the likelihood of a release to surface soils in the area resulting from SCUTTLE.

\subsubsection{1 $\quad$ Fly-Over Data}

The fly-over survey performed in 1994 shows low levels of detectable radioactivity (Hendricks and Riedhauser, 1999). This CAS is located within the contaminant extent from the SEDAN test (CAS 10-45-01). Thus, the low levels of radiological contamination detected in this area are not attributable to the SCUTTLE detonation but are related to the contamination extent of CAS 10-45-01, which will be addressed with a future CAU closure. 
The fly-over survey process is well established and has been used at many sites to make the "yes-no" type of decision used in this SAFER Plan (NNSA/NSO, 2005). The fly-over data have been used in a semi-quantitative way to support the conclusion made based on operational history that a release to surface soils did not occur as a result of SCUTTLE operations. There were 138 measurements collected within a 500-m radius of the surface ground zero of the SCUTTLE detonation (Figure 9). While the fly-over data, depicted in Figure 9, are shown as points, the field of view of the detector is large; thus, the fly-over survey provided 100-percent coverage of this area. These data were analyzed as described in Proctor (1997) and Hendricks and Riedhauser (1999). The results of the analyzed survey data are shown in Table 17.

All measurements for americium-241 were below the detection limit, and 116 measurements for total man-made radioactivity were greater than the detection limit. These measurements were made in the known, contiguous contaminant plume of CAS 10-45-01, and this area will be addressed with a future CAU closure. However, as shown in Section 2.8.3.3, these data are also below the dose limit.

TABLE 17. CAS 02-23-12 Fly-OVER DATA SuMmARY

\begin{tabular}{|l|c|c|c|}
\hline MEASUREMENT TYPE & $\begin{array}{c}\text { NUMBER OF } \\
\text { MEASUREMENTS }\end{array}$ & $\begin{array}{c}\text { APPROXIMATE } \\
\text { DETECTION LIMIT }\end{array}$ & $\begin{array}{c}\text { NUMBER } \\
\text { MEASUREMENTS } \\
\text { >DETECTION LIMIT }\end{array}$ \\
\hline Total man-made & 138 & $1.5 \mathrm{microR} / \mathrm{hr}$ & 116 \\
\hline americium-241 & 138 & $50 \mathrm{cps}$ & 0 \\
\hline
\end{tabular}

The fly-over data presented above represent many individual measurements (referred to as point data), and each measurement is corrected for background radiation. The fly-over survey process continuously collects background radiation levels then corrects each measurement to remove it, resulting in data that show the added man-made radiation from testing or other activities. The fly-over measurements for total man-made radiation are very sensitive, with the detection limit of $1.5 \mathrm{microR} / \mathrm{hr}$. Typical background exposure rates are approximately $15 \mathrm{microR} / \mathrm{hr}$. Thus, the detection limit of $1.5 \mathrm{microR} / \mathrm{hr}$ results in detection of man-made radiation that is greater than approximately 10 percent of natural background radiation.

The fly-over surveys are very sensitive to americium-241. Americium-241 sensitivity is approximately $50 \mathrm{cps}$. A specific correlation to soil concentration values was not performed; however, a conservative correlation of $50 \mathrm{cps}$ to $300 \mathrm{nCi} / \mathrm{m}^{2}$ has been estimated by RSL based on other similar flights and the flight altitude of $200 \mathrm{ft}$. This value, $300 \mathrm{nCi} / \mathrm{m}^{2}$, was then compared to RIDP measurements made in non-operational areas of the NTS where no local releases of radioactive material occurred to determine whether the fly-over survey is capable of discerning levels of radioactivity indicative of a widespread radiological release. Since the RIDP values in the non-operational areas range from 24 to $573 \mathrm{nCi} / \mathrm{m}^{2}$ and the fly-over sensitivity is approximately $300 \mathrm{nCi} / \mathrm{m}^{2}$, this shows that the fly-over survey is capable of discerning where operational releases have occurred. No americium-241 fly-over survey measurements were greater than the detection limit, similar to the non-operational areas of the NTS. These data confirm that there was not a widespread release to surface soils. 


\subsubsection{Contaminated Land Report Data}

Results of the surveys conducted for BN (2000), which included radiological surveys in the immediate area of CAS 02-23-12, were used qualitatively to support the conclusions derived from the operational history. Measurements collected included exposure rates and FIDLER readings. Removable alpha and beta/gamma contamination were also assessed. Measurements were collected within the boundaries of URMAs and around the perimeter of these areas. Table 18 presents the results of these surveys (BN, 2000).

TABle 18. CAS 02-23-12 CONTAMINATEd LAND SURVEY DATA SUMmaRY

\begin{tabular}{||l|r|r|r|r|r||}
\hline $\begin{array}{c}\text { MeAsUREMENT } \\
\text { TYPE }\end{array}$ & $\begin{array}{c}\text { NUMBER OF } \\
\text { MEASUREMENTS }\end{array}$ & $\begin{array}{c}\text { MAXIMUM } \\
\text { VALUE }\end{array}$ & $\begin{array}{c}\text { MINIMUM } \\
\text { VALUE }\end{array}$ & $\begin{array}{c}\text { AVERAGE } \\
\text { VALUE }\end{array}$ & $\begin{array}{c}\text { APPROXIMATE } \\
\text { INSTRUMENT } \\
\text { SENSITIVITY }\end{array}$ \\
\hline Removable Alpha & 8 & $2 \mathrm{dpm} / 100 \mathrm{~cm}^{2}$ & $0 \mathrm{dpm} / 100 \mathrm{~cm}^{2}$ & $0.8 \mathrm{dpm} / 100 \mathrm{~cm}^{2}$ & $5 \mathrm{dpm} / 100 \mathrm{~cm}^{2}$ \\
\hline Removable Beta & 8 & $3 \mathrm{dpm} / 100 \mathrm{~cm}^{2}$ & $0 \mathrm{dpm} / 100 \mathrm{~cm}^{2}$ & $0.5 \mathrm{dpm} / 100 \mathrm{~cm}^{2}$ & $16 \mathrm{dpm} / 100 \mathrm{~cm}^{2}$ \\
\hline Exposure Rate & 8 & $20 \mathrm{uR} / \mathrm{hr}$ & $10 \mathrm{uR} / \mathrm{hr}$ & $16 \mathrm{uR} / \mathrm{hr}^{2}$ & $20 \mathrm{uR} / \mathrm{hr}^{1}$ \\
\hline FIDLER & 8 & $90 \mathrm{cps}$ & $70 \mathrm{cps}$ & $75 \mathrm{cps}$ & $100 \mathrm{cps}$ \\
\hline
\end{tabular}

${ }^{1}$ Approximate Instrument Sensitivity is estimated based on typical background values and instrument performance. All values reported below the instrument sensitivity are estimates only.

All values were below detection limits. These ground-based survey data consist of measurements that are focused in the post-test drilling areas in and around the URMAs, thereby augmenting the wide-area data collected via fly-over surveys. These data provide an additional resource indicating that post-test drilling operations did not lead to surface soil contamination.

The NV/YMP RadCon Manual (NNSA/NSO, 2004b) is used at the NTS to implement the requirements set forth in $10 \mathrm{CFR} 835$. The manual allows for the release of areas from radiological controls when certain radiological limits are met. The limits were established as acceptable levels for use by the general public and, thus, are conservative given the ongoing controls at CAS 02-23-12 and the lack of both public and worker access to the site. Table 19 outlines these release values. BN (2000) survey measurements in the area of CAS 02-23-12 are well below the radiological control limits outlined in Table 19.

\subsubsection{3 $\quad \underline{\text { RIDP Data }}$}

Several RIDP measurements were taken within $500 \mathrm{~m}$ of the SCUTTLE site (Figure 9). RIDP values were used to evaluate operational history and support the conclusion that the elevated exposure rate readings observed during the drilling operations did not indicate a widespread contaminant release. RIDP measurements taken within $500 \mathrm{~m}$ of the SCUTTLE site were evaluated against limits set forth in Anspaugh and Daniels (1995) as explained in Section 2.2.4.3 of this SAFER Plan. Table 20 provides the maximum, minimum, and average values of these data and compares the maximum value to the limits set forth in Anspaugh and Daniels (1995). All values are well below these limits. This evaluation is not intended as a formal dose assessment but as a means by which these data may be compared to evaluate the validity of the operational history release assumptions.

Results for radionuclides measured by RIDP in the SCUTTLE vicinity and at the non-operational areas where releases did not occur were compared. One slightly elevated RIDP measurement was collected within the known contaminant plume of CAS 10-45-01 and is consistent with the operational history. Therefore, these results support the process knowledge, Contaminated Land Report survey data, and fly-over data. 


\section{TAble 19. Surface Contamination Release VALUES ${ }^{1}$ IN DPM/100 CM$^{2}$}

\begin{tabular}{||l|l|l||}
\hline \multicolumn{1}{|c|}{ RADIONUCLIDE } & \multicolumn{1}{|c||}{ REMOVABLE $^{2,4}$} & $\begin{array}{c}\text { TOTAL (FIXED } \\
\text { +REMOVABLE) }\end{array}$ \\
\hline $\begin{array}{l}\text { natural uranium, uranium-235, uranium-238, and associated decay } \\
\text { products }\end{array}$ & $1,000^{7}$ & $5,000^{7}$ \\
\hline $\begin{array}{l}\text { transuranics, radium-226, radium-228, thorium-230, thorium-228, } \\
\text { protactinium-231, actinium-227, iodine-125, and iodine-129 }\end{array}$ & 20 & 500 \\
\hline $\begin{array}{l}\text { natural thorium, thorium-232, strontium-90, radium-223, radium- } \\
\text { 224, uranium-232, iodine-126, iodine-131, and iodine-133 }\end{array}$ & 200 & 1,000 \\
\hline $\begin{array}{l}\text { beta-gamma emitters (nuclides with decay modes other than alpha } \\
\text { emission or spontaneous fission), except strontium-90 and others } \\
\text { noted above }\end{array}$ & 1,000 & 5,000 \\
\hline tritium and tritiated compounds $^{6}$ & 10,000 & N/A \\
\hline
\end{tabular}

1 The values in this table, with the exception noted in footnote 5, apply to radioactive contamination deposited on, but not incorporated into the interior or matrix of, the contaminated item. Where surface contamination by both alpha- and beta-gamma-emitting nuclides exists, the limits established for alpha- and beta-gamma-emitting nuclides apply independently.

2 As used in this table, dpm (disintegrations per minute) means the rate of emission by radioactive material as determined by correcting the counts per minute observed by an appropriate detector for background, efficiency, and geometric factors associated with the instrumentation.

3 The levels may be averaged over 1 square meter provided the maximum surface activity in any area of $100 \mathrm{~cm}^{2}$ is less than three times the value specified. For purposes of averaging, any square meter of surface shall be considered to be above the surface contamination value if: (1) From measurements of a representative number of sections it is determined that the average contamination level exceeds the applicable value; or (2) it is determined that the sum of the activity of all isolated spots or particles in any $100 \mathrm{~cm}^{2}$ area exceeds three times the applicable value.

4 The amount of removable radioactive material per $100 \mathrm{~cm}^{2}$ of surface area should be determined by swiping the area with dry filter or soft absorbent paper, applying moderate pressure, and then assessing the amount of radioactive material on the swipe with an appropriate instrument of known efficiency. (Note: The use of dry material may not be appropriate for tritium.) When removable contamination on objects of surface area less than $100 \mathrm{~cm}^{2}$ is determined, the activity per unit area shall be based on the actual area and the entire surface shall be wiped. It is not necessary to use swiping techniques to measure removable contamination levels if direct scan surveys indicate that the total residual surface contamination levels are within the limits for removable contamination.

5 This category of radionuclides includes mixed fission products, including the strontium-90 present in them. It does not apply to strontium-90 which has been separated from the other fission products or mixtures where the strontium-90 has been enriched.

6 Tritium contamination may diffuse into the volume or matrix of materials. Evaluation of surface contamination shall consider the extent to which such contamination may migrate to the surface in order to ensure the surface contamination value provided in this appendix is not exceeded. Once this contamination migrates to the surface, it may be removable, not fixed; therefore, a "Total" value does not apply.

7 (alpha)

TABLE 20. CAS 02-23-12 RIDP DATA SUMMARY

\begin{tabular}{||l|r|r|r|r|r||}
\hline RADIONUCLIDE & $\begin{array}{c}\text { NUMBER OF } \\
\text { MEASUREMENTS }\end{array}$ & $\begin{array}{c}\text { MAXIMUM } \\
\text { VALUE } \\
\left(\mathrm{nCi} / \mathrm{m}^{2}\right)\end{array}$ & $\begin{array}{c}\text { MINIMUM } \\
\text { VALUE } \\
\left(\mathrm{nCi} / \mathrm{m}^{2}\right)\end{array}$ & $\begin{array}{c}\text { AvERAGE } \\
\text { VALUE } \\
\left(\mathrm{nCi} / \mathrm{m}^{2}\right)\end{array}$ & $\begin{array}{c}\text { MAX VALUE } \\
\text { FRACTION OF } \\
\text { DCG }\end{array}$ \\
\hline americium-241 & 3 & 129.52 & 49.75 & 79.81 & 0.05 \\
\hline cobalt-60 & 3 & 2.03 & 0.58 & 1.13 & 0.00 \\
\hline cesium-134 & 3 & 0.00 & 0.00 & 0.00 & 0.00 \\
\hline cesium-137 & 3 & 916.84 & 112.19 & 552.80 & 0.28 \\
\hline europium-152 & 3 & 19.59 & 8.83 & 14.74 & 0.01 \\
\hline europium-154 & 3 & 12.23 & 5.76 & 9.97 & 0.01 \\
\hline europium-155 & 3 & 2.05 & 1.16 & 1.53 & 0.00 \\
\hline lutetium-174 & 3 & 0.60 & 0.23 & 0.37 & 0.00 \\
\hline plutonium-238 & 3 & 110.08 & 42.29 & 67.84 & 0.02 \\
\hline plutonium-239 & 3 & 741.95 & 284.96 & 457.19 & 0.14 \\
\hline rhodium-101 & 3 & 0.12 & 0.10 & 0.10 & 0.00 \\
\hline ruthenium-106 & 3 & 0.00 & 0.00 & 0.00 & 0.00 \\
\hline antimony-125 & 3 & 0.12 & 0.07 & 0.09 & 0.00 \\
\hline strontium-90 & 3 & 732.01 & 89.58 & 441.36 & 0.00 \\
\hline \hline
\end{tabular}




\subsubsection{ConcLusion}

SCUTTLE was an underground detonation with associated post-test drilling operations. The detonation cavity is part of the UGTA Sub-Project. The very low levels of contamination present near the site are not attributable to the SCUTTLE detonation but are associated with the SEDAN detonation, which will be addressed with a future CAU closure (Figure 7). There were no releases due to the post-test drilling, and elevated radiological readings recorded during the detonation itself are not indicative of a release to the surface soils. This is supported by process knowledge, 100-percent coverage fly-over survey data, focused measurements provided by the Contaminated Land Report survey data, and RIDP data. The demonstrated lack of radiological releases to the surface soils related to CAS 02-23-12 leads to the conclusion that there is no credible exposure pathway that could cause an NTS worker to receive a dose greater than $25 \mathrm{mrem} / \mathrm{yr}$ at this CAS.

This CAS requires no additional controls under the FFACO. While not required to achieve FFACO closure under the DQOs developed for CAU 107, the site is posted under 10 CFR 835 as a URMA, thereby further ensuring that an NTS worker will not receive a dose greater than $25 \mathrm{mrem} / \mathrm{yr}$. Based on the information presented above, data are adequate to support a closure option of no further action. 


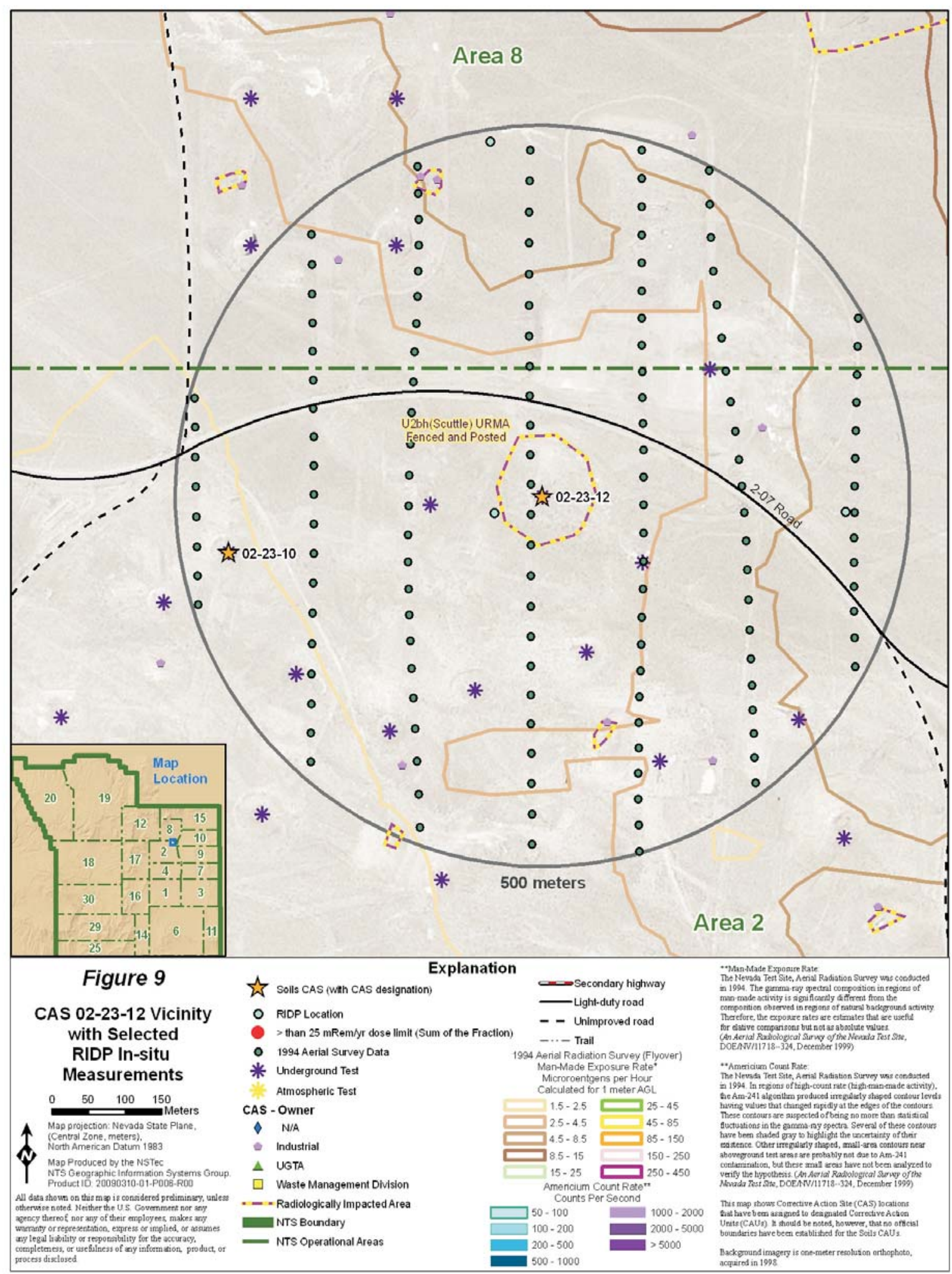

FIGURE 9 


\subsection{CAS 03-23-24, SeaWeed B CONTAMination ARea}

CAS 03-23-24 was designated to address potential surface soil contamination associated with the SEAWEED B underground nuclear weapon detonation. This site was added to the FFACO in 2006 because a radiological release during the detonation of SEAWEED B was listed in DOE/NV (1996). REECo (1991) does not provide information about this site. The SEAWEED $\mathrm{B}$ detonation did not form a subsidence crater. The area is a potential crater area and no stability study has been completed, so both access and future land use are limited. The SEAWEED B detonation cavity is part of the UGTA Sub-Project.

\subsubsection{OPERATIONAL HistoRY}

The SEAWEED B test, conducted on October 16, 1969, was part of Operation Mandrel. The test, detonated in emplacement hole U3hkd, had a yield of less than $20 \mathrm{kt}$ (DOE/NV, 2000). Stationary radiation monitors were placed in an arc around the surface ground zero of the test. The maximum gamma exposure rate measured was $10.5 \mathrm{R} / \mathrm{hr}$. A re-entry survey was conducted after the test, and the maximum gamma exposure rate measured was $0.5 \mathrm{mR} / \mathrm{hr}$. No alpha contamination was detected (REECo, 1973a). No post-test drilling was conducted for the SEAWEED B test (RSN, 1991).

\subsubsection{RELEASE INFORMATION}

DOE/NV (1996) documented radiological releases from the detonation of the SEAWEED B weapons test. The releases included xenon-138. Xenon-138 is a gaseous radionuclide with a short half-life and is not suspected to be present in the soil. The half-life of this radionuclide is approximately 14 minutes (Nuclear Data Center, 2006). Elevated exposure rate readings were noted as a result of this release. Operational history indicates this type of elevated reading was typical when radiological releases occurred during detonation and is not a unique indicator of surface radiological contamination. Furthermore, the measurements taken by the stationary monitors during the detonation and the subsequent measurements taken during the post-test re-entry survey showed a large decrease in radioactivity minutes after the test. This indicates that the released material was dispersed quickly, decayed rapidly, and did not settle onto the surface soils in the area.

\subsubsection{HistoricAL CHARACTERIZATION INFORMATION}

The following data were used to evaluate the potential surface release for CAS 03-23-24 and determine the likelihood of a release to surface soils in the area resulting from SEAWEED B.

\subsubsection{Fly-Over Data}

The fly-over survey performed in 1994 does not show detectable levels of radionuclides in the area of this CAS and does not identify any nearby areas as ROIs (Hendricks and Riedhauser, 1999). The fly-over survey process is well established and has been used at many sites to make the "yes-no" type of decision used in this SAFER Plan (NNSA/NSO, 2005). The fly-over data have been used in a semi-quantitative way to support the conclusion made based on operational history that a release to surface soils did not occur as a result of the SEAWEED B detonation or associated activities. There were 137 measurements collected within a 500-m radius of the SEAWEED B detonation (Figure 10). While the fly-over data, depicted in Figure 10, are shown as points, the field of view of the detector is large; thus, the fly-over survey provided 100-percent 
coverage of this area. These data were analyzed as described in Proctor (1997) and Hendricks and Riedhauser (1999). The results of the analyzed survey data are shown in Table 21. All measurements were less than the detection limit of the instrumentation.

Table 21. CAS 03-23-24 Fly-Over Data Summary

\begin{tabular}{|l|c|c|c|}
\hline MEASUREMENT TYPE & $\begin{array}{c}\text { NUMBER OF } \\
\text { MEASUREMENTS }\end{array}$ & $\begin{array}{c}\text { APPROXIMATE } \\
\text { DETECTION LIMIT }\end{array}$ & $\begin{array}{c}\text { NUMBER } \\
\text { MEASUREMENTS } \\
\text { >DETECTION LIMIT }\end{array}$ \\
\hline Total man-made & 137 & $1.5 \mathrm{microR} / \mathrm{hr}$ & 0 \\
\hline americium-241 & 137 & $50 \mathrm{cps}$ & 0 \\
\hline
\end{tabular}

The fly-over data presented above represent many individual measurements (referred to as point data), and each measurement is corrected for background radiation. The fly-over survey process continuously collects background radiation levels then corrects each measurement to remove it, resulting in data that show the added man-made radiation from testing or other activities. The fly-over measurements for total man-made radiation are very sensitive, with the detection limit of $1.5 \mathrm{microR} / \mathrm{hr}$. Typical background exposure rates are approximately $15 \mathrm{microR} / \mathrm{hr}$. Thus, the detection limit of $1.5 \mathrm{microR} / \mathrm{hr}$ results in detection of man-made radiation that is greater than approximately 10 percent of natural background radiation.

The fly-over surveys are very sensitive to americium-241. Americium-241 sensitivity is approximately $50 \mathrm{cps}$. A specific correlation to soil concentration values was not performed; however, a conservative correlation of $50 \mathrm{cps}$ to $300 \mathrm{nCi} / \mathrm{m}^{2}$ has been estimated by RSL based on other similar flights and the flight altitude of $200 \mathrm{ft}$. This value, $300 \mathrm{nCi} / \mathrm{m}^{2}$, was then compared to RIDP measurements made in non-operational areas of the NTS where no local releases of radioactive material occurred to determine whether the fly-over survey is capable of discerning levels of radioactivity indicative of a widespread radiological release. Since the RIDP values in the non-operational areas range from 24 to $573 \mathrm{nCi} / \mathrm{m}^{2}$ and the fly-over sensitivity is approximately $300 \mathrm{nCi} / \mathrm{m}^{2}$, this shows that the fly-over survey is capable of discerning where operational releases have occurred. No americium-241 fly-over survey measurements were greater than the detection limit, similar to the non-operational areas of the NTS. These data confirm that there was not a widespread release to surface soils.

\subsubsection{Contaminated Land Report Data}

Results of the surveys conducted in support of BN (2000) were used qualitatively to support the conclusions derived from the operational history. The surveys conducted for BN (2000) included radiological surveys in the immediate area of CAS 03-23-24. Measurements collected included exposure rates and FIDLER readings. Removable alpha and beta/gamma contamination were also assessed. Measurements were collected within the boundaries of URMAs and around the perimeter of these areas. Table 22 presents the results of these surveys (BN, 2000). 
TABle 22. CAS 03-23-24 Contaminated LAND SuRvey DATA Summary

\begin{tabular}{||l|r|r|r|r|r||}
\hline $\begin{array}{c}\text { MEASUREMENT } \\
\text { TYPE }\end{array}$ & $\begin{array}{c}\text { NUMBER OF } \\
\text { MEASUREMENTS }\end{array}$ & $\begin{array}{c}\text { MAXIMUM } \\
\text { VALUE }\end{array}$ & $\begin{array}{c}\text { MINIMUM } \\
\text { VALUE }\end{array}$ & $\begin{array}{c}\text { AVERAGE } \\
\text { VALUE }\end{array}$ & $\begin{array}{c}\text { APPROXIMATE } \\
\text { InSTRUMENT } \\
\text { SENSITIVITY }\end{array}$ \\
\hline Removable Alpha & 5 & $5 \mathrm{dpm} / 100 \mathrm{~cm}^{2}$ & $0 \mathrm{dpm} / 100 \mathrm{~cm}^{2}$ & $1.4 \mathrm{dpm} / 100 \mathrm{~cm}^{2}$ & $5 \mathrm{dpm} / 100 \mathrm{~cm}^{2}$ \\
\hline Removable Beta & 5 & $0 \mathrm{dpm} / 100 \mathrm{~cm}^{2}$ & $0 \mathrm{dpm} / 100 \mathrm{~cm}^{2}$ & $0 \mathrm{dpm} / 100 \mathrm{~cm}^{2}$ & $16 \mathrm{dpm} / 100 \mathrm{~cm}^{2}$ \\
\hline Exposure Rate & 5 & $15 \mathrm{uR} / \mathrm{hr}$ & $15 \mathrm{uR} / \mathrm{hr}$ & $15 \mathrm{uR} / \mathrm{hr}$ & $20 \mathrm{uR} / \mathrm{hr}^{1}$ \\
\hline FIDLER & 5 & $70 \mathrm{cps}$ & $60 \mathrm{cps}$ & $65 \mathrm{cps}$ & $100 \mathrm{cps}$ \\
\hline \hline
\end{tabular}

${ }^{1}$ Approximate Instrument Sensitivity is estimated based on typical background values and instrument performance. All values reported below the instrument sensitivity are estimates only.

All values were below detection limits. These ground-based survey data consist of measurements that are focused in the immediate area of the CAS, thereby augmenting the wide-area data collected via fly-over surveys. These data provide an additional resource indicating that SEAWEED B operations did not lead to surface soil contamination.

The NV/YMP RadCon Manual (NNSA/NSO, 2004b) is used at the NTS to implement the requirements set forth in 10 CFR 835 . The manual allows for the release of areas from radiological controls when certain radiological limits are met. The limits were established as acceptable levels for use by the general public and, thus, are conservative given the ongoing controls at CAS 03-23-24 and the lack of both public and worker access to the site. Table 23 outlines these release values. BN (2000) survey measurements in the area of CAS 03-23-24 are well below the radiological control limits outlined in Table 23.

\subsubsection{3 $\quad \underline{\text { RIDP Data }}$}

The RIDP did not include the area of this CAS because radiological contamination was not suspected in this area (McArthur and Mead, 1987). Figure 10 shows the single RIDP measurement collected in the vicinity of this CAS, indicating an NTS worker dose of less than $25 \mathrm{mrem} / \mathrm{yr}$. 


\section{Table 23. Surface Contamination Release VAlues ${ }^{1}$ IN DPM/100 CM$^{2}$}

\begin{tabular}{|l|l|l||}
\hline \multicolumn{1}{|c|}{ RADIONUCLIDE } & \multicolumn{1}{|c||}{ REMOVABLE $^{2,4}$} & $\begin{array}{c}\text { TOTAL (FIXED } \\
\text { +REMOVABLE) }\end{array}$ \\
\hline $\begin{array}{l}\text { natural uranium, uranium-235, uranium-238, and associated decay } \\
\text { products }\end{array}$ & $1,000^{7}$ & $5,000^{7}$ \\
\hline $\begin{array}{l}\text { transuranics, radium-226, radium-228, thorium-230, thorium-228, } \\
\text { protactinium-231, actinium-227, iodine-125, and iodine-129 }\end{array}$ & 20 & 500 \\
\hline $\begin{array}{l}\text { natural thorium, thorium-232, strontium-90, radium-223, radium- } \\
\text { 224, uranium-232, iodine-126, iodine-131, and iodine-133 }\end{array}$ & 200 & 1,000 \\
\hline $\begin{array}{l}\text { beta-gamma emitters (nuclides with decay modes other than alpha } \\
\text { emission or spontaneous fission), except strontium-90 and others } \\
\text { noted above }\end{array}$ & 1,000 & \\
\hline tritium and tritiated compounds $^{6}$ & 10,000 & 5,000 \\
\hline
\end{tabular}

1 The values in this table, with the exception noted in footnote 5, apply to radioactive contamination deposited on, but not incorporated into the interior or matrix of, the contaminated item. Where surface contamination by both alpha- and beta-gamma-emitting nuclides exists, the limits established for alpha- and beta-gamma-emitting nuclides apply independently.

2 As used in this table, dpm (disintegrations per minute) means the rate of emission by radioactive material as determined by correcting the counts per minute observed by an appropriate detector for background, efficiency, and geometric factors associated with the instrumentation.

3 The levels may be averaged over 1 square meter provided the maximum surface activity in any area of $100 \mathrm{~cm}^{2}$ is less than three times the value specified. For purposes of averaging, any square meter of surface shall be considered to be above the surface contamination value if: (1) From measurements of a representative number of sections it is determined that the average contamination level exceeds the applicable value; or (2) it is determined that the sum of the activity of all isolated spots or particles in any $100 \mathrm{~cm}^{2}$ area exceeds three times the applicable value.

4 The amount of removable radioactive material per $100 \mathrm{~cm}^{2}$ of surface area should be determined by swiping the area with dry filter or soft absorbent paper, applying moderate pressure, and then assessing the amount of radioactive material on the swipe with an appropriate instrument of known efficiency. (Note: The use of dry material may not be appropriate for tritium.) When removable contamination on objects of surface area less than $100 \mathrm{~cm}^{2}$ is determined, the activity per unit area shall be based on the actual area and the entire surface shall be wiped. It is not necessary to use swiping techniques to measure removable contamination levels if direct scan surveys indicate that the total residual surface contamination levels are within the limits for removable contamination.

5 This category of radionuclides includes mixed fission products, including the strontium-90 present in them. It does not apply to strontium-90 which has been separated from the other fission products or mixtures where the strontium-90 has been enriched.

6 Tritium contamination may diffuse into the volume or matrix of materials. Evaluation of surface contamination shall consider the extent to which such contamination may migrate to the surface in order to ensure the surface contamination value provided in this appendix is not exceeded. Once this contamination migrates to the surface, it may be removable, not fixed; therefore, a "Total" value does not apply.

7 (alpha)

\subsubsection{CONCLUSION}

SEAWEED B was an underground detonation with no associated post-test drilling operations. The detonation cavity is part of the UGTA Sub-Project. There was a release of short-lived gaseous radionuclides due to the detonation itself, but elevated radiological readings recorded during the detonation are not indicative of a release to the surface soils. This is supported by process knowledge, 100-percent coverage fly-over survey data, and focused measurements provided by the Contaminated Land Report survey data. The demonstrated lack of radiological releases to the surface soils in the vicinity of CAS 03-23-24 leads to the conclusion that there is no credible exposure pathway that could cause an NTS worker to receive a dose greater than 25 $\mathrm{mrem} / \mathrm{yr}$ at this CAS.

This CAS requires no additional controls under the FFACO. While not required to achieve FFACO closure under the DQOs developed for CAU 107, the site is posted under 10 CFR 835 as a URMA, thereby further ensuring that an NTS worker will not receive a dose greater than $25 \mathrm{mrem} / \mathrm{yr}$. Based on the information presented above, data are adequate to support a closure option of no further action. 


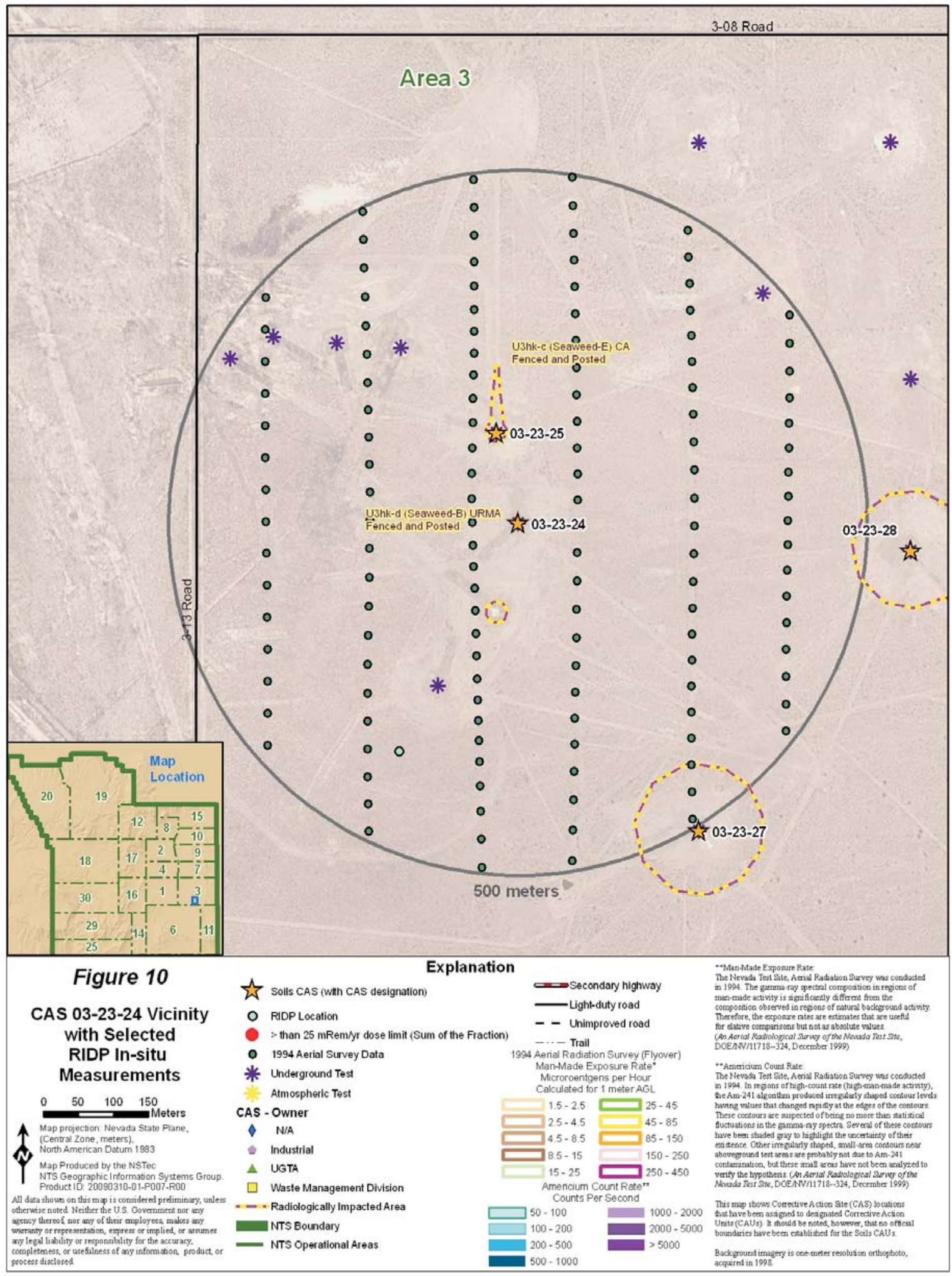

FIGURE 10 


\subsection{CAS 03-23-27, AdZe CONTAMINATION AREA}

CAS 03-23-27 was designated to address potential surface soil contamination associated with the ADZE underground nuclear weapons test. This site was recently added to the FFACO because of post-test cable pull activities documented in REECo (1973a). This CAS consists of a berm historically identified as being radiologically contaminated (REECo, 1995). The ADZE test did not form a subsidence crater. The area is a potential subsidence crater and no stability study has been completed, so both access and future land use are limited. The ADZE detonation cavity is part of the UGTA Sub-Project. This area is posted as a URMA, likely due to the deep underground source term that resulted from the nuclear test (Johnston, 2007).

\subsubsection{OPERATIONAL HISTORY}

The ADZE test, conducted on May 28, 1968, was part of Operation Crosstie. The test, detonated in emplacement hole U3fw, had a yield of less than $20 \mathrm{kt}$ (DOE/NV, 2000). Radiological contamination was suspected to be present from post-test cable pull operations. The maximum gamma exposure rate measured during the cable pull operation was $60 \mathrm{R} / \mathrm{hr}$ on the cable. No alpha contamination was detected (REECo, 1973a). The cable has been removed.

\subsubsection{RELEASE INFORMATION}

DOE/NV (1996) documented radiological releases resulting from the cable pull operations for the ADZE test. The releases included iodine-133, iodine-135, and xenon-138. These are gaseous radionuclides with short half-lives and are not expected to be present in the soil. The longest half-life of these radionuclides is approximately 57 days (Nuclear Data Center, 2006). Elevated exposure rate readings were noted during the cable pull operations. Operational history indicates this type of elevated reading was typical of post-test cable pulls and is not a unique indicator of surface radiological contamination. The cable pull operation allowed gaseous radionuclides to escape. These gases diffused quickly and did not settle onto surface soils, explaining why no contamination was detected in environmental samples (Kathren, 1984).

\subsubsection{HiSTORICAL CHARACTERIZATION INFORMATION}

The following data were used to evaluate the potential surface release for CAS 03-23-27 and determine the likelihood of a release to surface soils in the area resulting from ADZE.

\subsubsection{1 $\quad$ Fly-Over Data}

The 1994 fly-over survey does not show detectable levels of radionuclides in the area of this CAS and does not identify any nearby areas as ROIs (Hendricks and Riedhauser, 1999). The fly-over survey process is well established and has been used at many sites to make the "yes-no" type of decision used in this SAFER Plan (NNSA/NSO, 2005). The fly-over data have been used in a semi-quantitative way to support the conclusion based on operational history that a release to surface soils did not occur as a result of the ADZE detonation or associated activities. There were 140 measurements collected within a 500-m radius of the ADZE detonation (Figure 11). While fly-over data, depicted in Figure 11, are shown as points, the field of view is large; thus, the survey provided 100-percent coverage of the area. These data were analyzed as described in Proctor (1997) and Hendricks and Riedhauser (1999). The results of the analyzed survey data are shown in Table 24. All measurements were less than the detection limit. 
TABle 24. CAS 03-23-27 Fly-Over DATA Summary

\begin{tabular}{|l|c|c|c|}
\hline MEASUREMENT TYPE & $\begin{array}{c}\text { NUMBER OF } \\
\text { MEASUREMENTS }\end{array}$ & $\begin{array}{c}\text { APPROXIMATE } \\
\text { DETECTION LIMIT }\end{array}$ & $\begin{array}{c}\text { NUMBER } \\
\text { MEASUREMENTS } \\
\text { >DETECTION LIMIT }\end{array}$ \\
\hline Total man-made & 140 & $1.5 \mathrm{microR} / \mathrm{hr}$ & 0 \\
\hline americium-241 & 140 & $50 \mathrm{cps}$ & 0 \\
\hline
\end{tabular}

The fly-over data presented above represent many individual measurements (referred to as point data), and each measurement is corrected for background radiation. The fly-over survey process continuously collects background radiation levels then corrects each measurement to remove it, resulting in data that show the added man-made radiation from testing or other activities. The fly-over measurements for total man-made radiation are very sensitive, with the detection limit of $1.5 \mathrm{microR} / \mathrm{hr}$. Typical background exposure rates are approximately $15 \mathrm{microR} / \mathrm{hr}$. Thus, the detection limit of $1.5 \mathrm{microR} / \mathrm{hr}$ results in detection of man-made radiation that is greater than approximately 10 percent of natural background radiation.

The fly-over surveys are very sensitive to americium-241. Americium-241 sensitivity is approximately $50 \mathrm{cps}$. A specific correlation to soil concentration values was not performed; however, a conservative correlation of $50 \mathrm{cps}$ to $300 \mathrm{nCi} / \mathrm{m}^{2}$ has been estimated by RSL based on other similar flights and the flight altitude of $200 \mathrm{ft}$. This value, $300 \mathrm{nCi} / \mathrm{m}^{2}$, was then compared to RIDP measurements made in non-operational areas of the NTS where no local releases of radioactive material occurred to determine whether the fly-over survey is capable of discerning levels of radioactivity indicative of a widespread radiological release. Since the RIDP values in the non-operational areas range from 24 to $573 \mathrm{nCi} / \mathrm{m}^{2}$ and the fly-over sensitivity is approximately $300 \mathrm{nCi} / \mathrm{m}^{2}$, this shows that the fly-over survey is capable of discerning where operational releases have occurred. No americium-241 fly-over survey measurements were greater than the detection limit, similar to the non-operational areas of the NTS. These data confirm that there was not a widespread release to surface soils.

\subsubsection{Contaminated Land Report Data}

Results of the surveys conducted in support of BN (2000) were used qualitatively to support the conclusions derived from the operational history. The surveys conducted for BN (2000) included radiological surveys in the immediate area of CAS 03-23-27. Measurements collected included exposure rates and FIDLER readings. Removable alpha and beta/gamma contamination were also assessed. Measurements were collected along the perimeter of the URMA. Table 25 presents the results of these surveys (BN, 2000).

\section{TABLe 25. CAS 03-23-27 CONTAMinated LAND SuRVey DATA Summary}

\begin{tabular}{|l|r|r|r|r|r||}
\hline $\begin{array}{c}\text { MEASUREMENT } \\
\text { TYPE }\end{array}$ & $\begin{array}{c}\text { NUMBER OF } \\
\text { MEASUREMENTS }\end{array}$ & $\begin{array}{c}\text { MAXIMUM } \\
\text { VALUE }\end{array}$ & $\begin{array}{c}\text { MINIMUM } \\
\text { VALUE }\end{array}$ & $\begin{array}{c}\text { AVERAGE } \\
\text { VALUE }\end{array}$ & $\begin{array}{c}\text { APPROXIMATE } \\
\text { InSTRUMENT } \\
\text { SENSITIVITY }\end{array}$ \\
\hline Removable Alpha & 11 & $5 \mathrm{dpm} / 100 \mathrm{~cm}^{2}$ & $0 \mathrm{dpm} / 100 \mathrm{~cm}^{2}$ & $1.2 \mathrm{dpm} / 100 \mathrm{~cm}^{2}$ & $5 \mathrm{dpm} / 100 \mathrm{~cm}^{2}$ \\
\hline Removable Beta & 11 & $11 \mathrm{dpm} / 100 \mathrm{~cm}^{2}$ & $0 \mathrm{dpm} / 100 \mathrm{~cm}^{2}$ & $0 \mathrm{dpm} / 100 \mathrm{~cm}^{2}$ & $16 \mathrm{dpm} / 100 \mathrm{~cm}^{2}$ \\
\hline Exposure Rate & 11 & $15 \mathrm{uR} / \mathrm{hr}$ & $10 \mathrm{uR} / \mathrm{hr}$ & $11 \mathrm{uR} / \mathrm{hr}$ & $20 \mathrm{uR} / \mathrm{hr}^{1}$ \\
\hline FIDLER & 11 & $75 \mathrm{cps}$ & $40 \mathrm{cps}$ & $64 \mathrm{cps}$ & $100 \mathrm{cps}$ \\
\hline
\end{tabular}

${ }^{1}$ Approximate Instrument Sensitivity is estimated based on typical background values and instrument performance. All values reported below the instrument sensitivity are estimates only. 
All values were below detection limits. These ground-based survey data consist of measurements that are focused in the area of the CAS, thereby augmenting the wide-area data collected via fly-over surveys. These data provide an additional resource indicating that ADZE operations did not lead to surface soil contamination.

The NV/YMP RadCon Manual (NNSA/NSO, 2004b) is used at the NTS to implement the requirements set forth in $10 \mathrm{CFR} 835$. The manual allows for the release of areas from radiological controls when certain radiological limits are met. The limits were established as acceptable levels for use by the general public and, thus, are conservative given the ongoing controls at CAS 03-23-27 and the lack of both public and worker access to the site. Table 26 outlines these release values. BN (2000) survey measurements in the area of CAS 03-23-27 are well below the radiological control limits outlined in Table 26.

TABle 26. SURFACE CONTAMination RELEASE VALUES ${ }^{1}$ IN DPM/100 CM$^{2}$

\begin{tabular}{|l|l|l||}
\hline \multicolumn{1}{|c|}{ RADIONUCLIDE } & \multicolumn{1}{|c||}{ REMOVABLE $^{2,4}$} & $\begin{array}{c}\text { TOTAL (FIXED } \\
\text { +REMOVABLE) }\end{array}$ \\
\hline $\begin{array}{l}\text { natural uranium, uranium-235, uranium-238, and associated decay } \\
\text { products }\end{array}$ & $1,000^{7}$ & $5,000^{7}$ \\
\hline $\begin{array}{l}\text { transuranics, radium-226, radium-228, thorium-230, thorium-228, } \\
\text { protactinium-231, actinium-227, iodine-125, and iodine-129 }\end{array}$ & 20 & 500 \\
\hline $\begin{array}{l}\text { natural thorium, thorium-232, strontium-90, radium-223, radium- } \\
\text { 224, uranium-232, iodine-126, iodine-131, and iodine-133 }\end{array}$ & 200 & 1,000 \\
\hline $\begin{array}{l}\text { beta-gamma emitters (nuclides with decay modes other than alpha } \\
\text { emission or spontaneous fission), except strontium-90 and others } \\
\text { noted above }^{5}\end{array}$ & 1,000 & 5,000 \\
\hline tritium and tritiated compounds $^{6}$ & 10,000 & N/A \\
\hline
\end{tabular}

1 The values in this table, with the exception noted in footnote 5, apply to radioactive contamination deposited on, but not incorporated into the interior or matrix of, the contaminated item. Where surface contamination by both alpha- and beta-gamma-emitting nuclides exists, the limits established for alpha- and beta-gamma-emitting nuclides apply independently.

2 As used in this table, dpm (disintegrations per minute) means the rate of emission by radioactive material as determined by correcting the counts per minute observed by an appropriate detector for background, efficiency, and geometric factors associated with the instrumentation.

3 The levels may be averaged over 1 square meter provided the maximum surface activity in any area of $100 \mathrm{~cm}^{2}$ is less than three times the value specified. For purposes of averaging, any square meter of surface shall be considered to be above the surface contamination value if: (1) From measurements of a representative number of sections it is determined that the average contamination level exceeds the applicable value; or (2) it is determined that the sum of the activity of all isolated spots or particles in any $100 \mathrm{~cm}^{2}$ area exceeds three times the applicable value.

4 The amount of removable radioactive material per $100 \mathrm{~cm}^{2}$ of surface area should be determined by swiping the area with dry filter or soft absorbent paper, applying moderate pressure, and then assessing the amount of radioactive material on the swipe with an appropriate instrument of known efficiency. (Note: The use of dry material may not be appropriate for tritium.) When removable contamination on objects of surface area less than $100 \mathrm{~cm}^{2}$ is determined, the activity per unit area shall be based on the actual area and the entire surface shall be wiped. It is not necessary to use swiping techniques to measure removable contamination levels if direct scan surveys indicate that the total residual surface contamination levels are within the limits for removable contamination.

5 This category of radionuclides includes mixed fission products, including the strontium- 90 present in them. It does not apply to strontium- 90 which has been separated from the other fission products or mixtures where the strontium-90 has been enriched.

6 Tritium contamination may diffuse into the volume or matrix of materials. Evaluation of surface contamination shall consider the extent to which such contamination may migrate to the surface in order to ensure the surface contamination value provided in this appendix is not exceeded. Once this contamination migrates to the surface, it may be removable, not fixed; therefore, a "Total" value does not apply.

7 (alpha)

\subsubsection{RIDP Data}

The RIDP did not include the area of this CAS because radiological contamination was not suspected in this area (McArthur and Mead, 1987). Figure 11 shows the single RIDP measurement collected in the vicinity of this CAS, indicating an NTS worker dose of less than $25 \mathrm{mrem} / \mathrm{yr}$. 


\subsubsection{CONCLUSION}

ADZE was an underground detonation with associated post-test cable pull operations. The detonation cavity is part of the UGTA Sub-Project. There were no releases due to the detonation itself, and elevated radiological readings recorded during the post-test cable pull are not indicative of a release to the surface soils. This is supported by process knowledge, 100-percent coverage fly-over survey data, and focused measurements provided by the Contaminated Land Report survey data. The demonstrated lack of radiological releases to the surface soils in the vicinity of CAS 03-23-27 leads to the conclusion that there is no credible exposure pathway that could cause an NTS worker to receive a dose greater than $25 \mathrm{mrem} / \mathrm{yr}$ at this CAS.

This CAS requires no additional controls under the FFACO. While not required to achieve FFACO closure under the DQOs developed for CAU 107, the site is posted under 10 CFR 835 as a URMA, thereby further ensuring that an NTS worker will not receive a dose greater than $25 \mathrm{mrem} / \mathrm{yr}$. Based on the information presented above, data are adequate to support a closure option of no further action. 


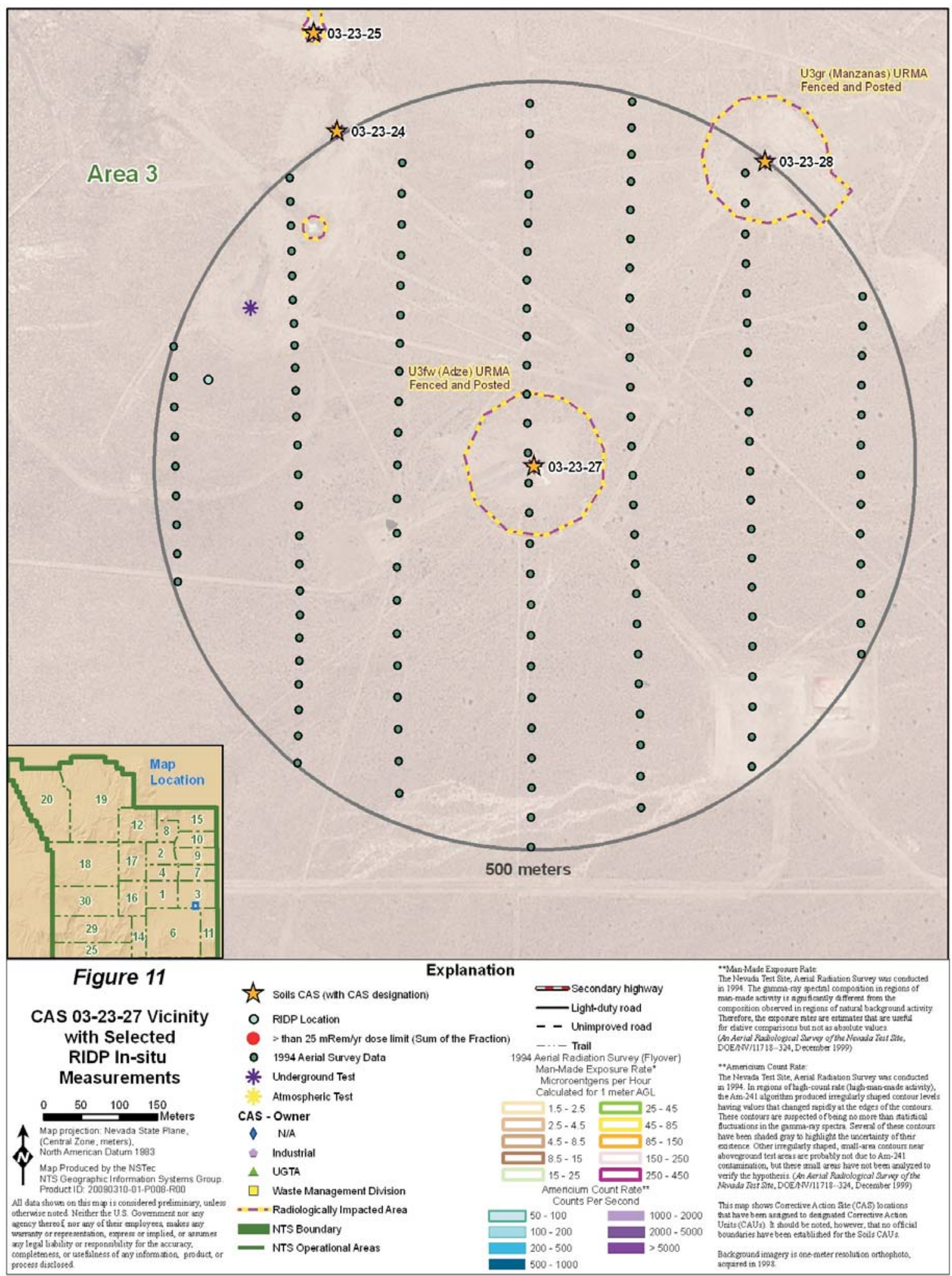

\section{FIGURE 11}




\subsection{CAS 03-23-28, Manzanas Contamination AREa}

CAS 03-23-28 was designated to address potential surface soil contamination associated with the MANZANAS underground nuclear weapons test. The site was recently added to the FFACO due to a radiological release during detonation of the MANZANAS test (DOE/NV, 1996). REECo (1991) does not provide information about this site. The MANZANAS test did not form a subsidence crater. The area is a potential subsidence crater and no stability study has been completed, so both access and future land use are limited. The MANZANAS detonation cavity is part of the UGTA Sub-Project. This area is posted as a URMA, likely due to the deep underground source term that resulted from the nuclear test (Johnston, 2007).

\subsubsection{OPERATIONAL HISTORY}

The MANZANAS test, conducted on May 21, 1970, was part of Operation Mandrel. The test, detonated in emplacement hole U3gr, had a yield of less than $20 \mathrm{kt}$ (DOE/NV, 2000). Radiation monitors placed in an arc around the surface ground zero, measured a maximum gamma exposure rate of $45 \mathrm{mR} / \mathrm{hr}$. A re-entry survey conducted after the test measured background levels of radioactivity and detected no alpha contamination. Post-test drilling documentation does not indicate abnormal events that may have caused surface contamination (REECo, 1973a).

\subsubsection{RELEASE INFORMATION}

DOE/NV (1996) documented radiological releases from the detonation of the MANZANAS test but not from post-test drilling activities. Elevated exposure rate readings were noted as a result of this release. Operational history indicates this type of elevated reading was typical when radiological releases occurred during detonation and is not a unique indicator of surface radiological contamination. Furthermore, the measurements taken by the stationary monitors during the detonation and subsequent measurements taken during the post-test re-entry survey showed a large decrease minutes after the test. This indicates that the released material was dispersed quickly, decayed rapidly, and did not settle onto the surface soils in the area.

\subsubsection{HistORICAL CHARACTERIZATION INFORMATION}

The following data were used to evaluate the potential surface release for CAS 03-23-28 and determine the likelihood of a release to surface soils in the area resulting from MANZANAS.

\subsubsection{Fly-Over Data}

The fly-over survey performed in 1994 does not show detectable levels of radionuclides in the area of this CAS and does not identify any nearby areas as ROIs (Hendricks and Riedhauser, 1999). The fly-over survey process is well established and has been used at many sites to make the "yes-no" type of decision used in this SAFER Plan (NNSA/NSO, 2005). The fly-over data have been used in a semi-quantitative way to support the conclusion made based on operational history that a release to surface soils did not occur as a result of the MANZANAS detonation or associated activities. There were 136 measurements collected within a 500-m radius of the MANZANAS detonation (Figure 12). While the fly-over data, depicted in Figure 12, are shown as points, the field of view of the detector is large; thus, the fly-over survey provided 100-percent coverage of this area. These data were analyzed as described in Proctor (1997) and Hendricks and Riedhauser (1999). The results of the analyzed survey data are shown in Table 27. All measurements were less than the detection limit of the instrumentation. 
TABle 27. CAS 03-23-28 Fly-Over DATA Summary

\begin{tabular}{|l|c|c|c|}
\hline MEASUREMENT TYPE & $\begin{array}{c}\text { NUMBER OF } \\
\text { MEASUREMENTS }\end{array}$ & $\begin{array}{c}\text { APPROXIMATE } \\
\text { DETECTION LIMIT }\end{array}$ & $\begin{array}{c}\text { NUMBER } \\
\text { MEASUREMENTS } \\
\text { >DETECTION LIMIT }\end{array}$ \\
\hline Total man-made & 136 & $1.5 \mathrm{microR} / \mathrm{hr}$ & 0 \\
\hline americium-241 & 136 & $50 \mathrm{cps}$ & 0 \\
\hline
\end{tabular}

The fly-over data presented above represent many individual measurements (referred to as point data), and each measurement is corrected for background radiation. The fly-over survey process continuously collects background radiation levels then corrects each measurement to remove it, resulting in data that show the added man-made radiation from testing or other activities. The fly-over measurements for total man-made radiation are very sensitive, with the detection limit of $1.5 \mathrm{microR} / \mathrm{hr}$. Typical background exposure rates are approximately $15 \mathrm{microR} / \mathrm{hr}$. Thus, the detection limit of $1.5 \mathrm{microR} / \mathrm{hr}$ results in detection of man-made radiation that is greater than approximately 10 percent of natural background radiation.

The fly-over surveys are very sensitive to americium-241. Americium-241 sensitivity is approximately $50 \mathrm{cps}$. A specific correlation to soil concentration values was not performed; however, a conservative correlation of $50 \mathrm{cps}$ to $300 \mathrm{nCi} / \mathrm{m}^{2}$ has been estimated by RSL based on other similar flights and the flight altitude of $200 \mathrm{ft}$. This value, $300 \mathrm{nCi} / \mathrm{m}^{2}$, was then compared to RIDP measurements made in non-operational areas of the NTS where no local releases of radioactive material occurred to determine whether the fly-over survey is capable of discerning levels of radioactivity indicative of a widespread radiological release. Since the RIDP values in the non-operational areas range from 24 to $573 \mathrm{nCi} / \mathrm{m}^{2}$ and the fly-over sensitivity is approximately $300 \mathrm{nCi} / \mathrm{m}^{2}$, this shows that the fly-over survey is capable of discerning where operational releases have occurred. No americium-241 fly-over survey measurements were greater than the detection limit, similar to the non-operational areas of the NTS. These data confirm that there was not a widespread release to surface soils.

\subsubsection{Contaminated Land Report Data}

Results of the surveys conducted in support of BN (2000) were used qualitatively to support the conclusions derived from the operational history. The surveys conducted for BN (2000) included radiological surveys in the immediate area of CAS 03-23-28. Measurements collected included exposure rates and FIDLER readings. Removable alpha and beta/gamma contamination were also assessed. Measurements were collected along the perimeter of the URMA. Table 28 presents the results of these surveys (BN, 2000).

\section{TABLe 28. CAS 03-23-28 CONTAMINATEd LAND SURVEY DATA SUMmaRY}

\begin{tabular}{||l|r|r|r|r|r||}
\hline \hline $\begin{array}{c}\text { MeASUREMENT } \\
\text { TyPE }\end{array}$ & $\begin{array}{c}\text { Number OF } \\
\text { MEASUREMENTS }\end{array}$ & \multicolumn{1}{c|}{$\begin{array}{c}\text { MAXIMUM } \\
\text { VAluE }\end{array}$} & $\begin{array}{c}\text { Minimum } \\
\text { VAlUE }\end{array}$ & $\begin{array}{c}\text { AVERAGE } \\
\text { VALUE }\end{array}$ & $\begin{array}{c}\text { APPROXIMATE } \\
\text { InSTRUMENT } \\
\text { SENSITIVITY }\end{array}$ \\
\hline Removable Alpha & 14 & $5 \mathrm{dpm} / 100 \mathrm{~cm}^{2}$ & $0 \mathrm{dpm} / 100 \mathrm{~cm}^{2}$ & $1 \mathrm{dpm} / 100 \mathrm{~cm}^{2}$ & $5 \mathrm{dpm} / 100 \mathrm{~cm}^{2}$ \\
\hline Removable Beta & 14 & $19 \mathrm{dpm} / 100 \mathrm{~cm}^{2}$ & $0 \mathrm{dpm} / 100 \mathrm{~cm}^{2}$ & $1.6 \mathrm{dpm} / 100 \mathrm{~cm}^{2}$ & $16 \mathrm{dpm} / 100 \mathrm{~cm}^{2}$ \\
\hline Exposure Rate & 14 & $15 \mathrm{uR} / \mathrm{hr}$ & $10 \mathrm{uR} / \mathrm{hr}$ & $11 \mathrm{uR} / \mathrm{hr}$ & $20 \mathrm{uR} / \mathrm{hr}^{1}$ \\
\hline FIDLER & 14 & $95 \mathrm{cps}$ & $80 \mathrm{cps}$ & $89 \mathrm{cps}$ & $100 \mathrm{cps}$ \\
\hline
\end{tabular}

${ }^{1}$ Approximate Instrument Sensitivity is estimated based on typical background values and instrument performance. All values reported below the instrument sensitivity are estimates only. 
All values were below detection limits. These ground-based survey data consist of measurements that are focused in the area of the CAS, thereby augmenting the wide-area data collected via fly-over surveys. These data provide an additional resource indicating that MANZANAS operations did not lead to surface soil contamination.

The NV/YMP RadCon Manual (NNSA/NSO, 2004b) is used at the NTS to implement the requirements set forth in $10 \mathrm{CFR} 835$. The manual allows for the release of areas from radiological controls when certain radiological limits are met. The limits were established as acceptable levels for use by the general public and, thus, are conservative given the ongoing controls at CAS 03-23-28 and the lack of both public and worker access to the site. Table 29 outlines these release values. BN (2000) survey measurements in the area of CAS 03-23-28 are well below the radiological control limits outlined in Table 29.

TABle 29. SURFACE CONTAMination RELEASE VALUES ${ }^{1}$ IN DPM/100 CM$^{2}$

\begin{tabular}{|l|l|l||}
\hline \multicolumn{1}{|c|}{ RADIONUCLIDE } & \multicolumn{1}{|c||}{ REMOVABLE $^{2,4}$} & $\begin{array}{c}\text { TOTAL (FIXED } \\
\text { +REMOVABLE) }\end{array}$ \\
\hline $\begin{array}{l}\text { natural uranium, uranium-235, uranium-238, and associated decay } \\
\text { products }\end{array}$ & $1,000^{7}$ & $5,000^{7}$ \\
\hline $\begin{array}{l}\text { transuranics, radium-226, radium-228, thorium-230, thorium-228, } \\
\text { protactinium-231, actinium-227, iodine-125, and iodine-129 }\end{array}$ & 20 & 500 \\
\hline $\begin{array}{l}\text { natural thorium, thorium-232, strontium-90, radium-223, radium- } \\
\text { 224, uranium-232, iodine-126, iodine-131, and iodine-133 }\end{array}$ & 200 & 1,000 \\
\hline $\begin{array}{l}\text { beta-gamma emitters (nuclides with decay modes other than alpha } \\
\text { emission or spontaneous fission), except strontium-90 and others } \\
\text { noted above }\end{array}$ & 1,000 & 5,000 \\
\hline tritium and tritiated compounds $^{6}$ & 10,000 & N/A \\
\hline
\end{tabular}

1 The values in this table, with the exception noted in footnote 5, apply to radioactive contamination deposited on, but not incorporated into the interior or matrix of, the contaminated item. Where surface contamination by both alpha- and beta-gamma-emitting nuclides exists, the limits established for alpha- and beta-gamma-emitting nuclides apply independently.

2 As used in this table, dpm (disintegrations per minute) means the rate of emission by radioactive material as determined by correcting the counts per minute observed by an appropriate detector for background, efficiency, and geometric factors associated with the instrumentation.

3 The levels may be averaged over 1 square meter provided the maximum surface activity in any area of $100 \mathrm{~cm}^{2}$ is less than three times the value specified. For purposes of averaging, any square meter of surface shall be considered to be above the surface contamination value if: (1) From measurements of a representative number of sections it is determined that the average contamination level exceeds the applicable value; or (2) it is determined that the sum of the activity of all isolated spots or particles in any $100 \mathrm{~cm}^{2}$ area exceeds three times the applicable value.

4 The amount of removable radioactive material per $100 \mathrm{~cm}^{2}$ of surface area should be determined by swiping the area with dry filter or soft absorbent paper, applying moderate pressure, and then assessing the amount of radioactive material on the swipe with an appropriate instrument of known efficiency. (Note: The use of dry material may not be appropriate for tritium.) When removable contamination on objects of surface area less than $100 \mathrm{~cm}^{2}$ is determined, the activity per unit area shall be based on the actual area and the entire surface shall be wiped. It is not necessary to use swiping techniques to measure removable contamination levels if direct scan surveys indicate that the total residual surface contamination levels are within the limits for removable contamination.

5 This category of radionuclides includes mixed fission products, including the strontium- 90 present in them. It does not apply to strontium- 90 which has been separated from the other fission products or mixtures where the strontium-90 has been enriched.

6 Tritium contamination may diffuse into the volume or matrix of materials. Evaluation of surface contamination shall consider the extent to which such contamination may migrate to the surface in order to ensure the surface contamination value provided in this appendix is not exceeded. Once this contamination migrates to the surface, it may be removable, not fixed; therefore, a "Total" value does not apply.

7 (alpha)

\subsubsection{3 $\quad \underline{\text { RIDP Data }}$}

The RIDP did not include the area of this CAS because radiological contamination was not suspected in this area (DRI, 2007). No RIDP measurements were used to evaluate this CAS. 


\subsubsection{CONCLUSION}

MANZANAS was an underground detonation with associated post-test drilling operations. The detonation cavity is part of the UGTA Sub-Project. There were no releases due to the post-test drilling, and elevated radiological readings recorded during the detonation itself are not indicative of a release to the surface soils. This is supported by process knowledge, 100-percent coverage fly-over survey data, and focused measurements provided by the Contaminated Land Report survey data. The demonstrated lack of radiological releases to the surface soils in the vicinity of CAS 03-23-28 leads to the conclusion that there is no credible exposure pathway that could cause an NTS worker to receive a dose greater than $25 \mathrm{mrem} / \mathrm{yr}$ at this CAS.

This CAS requires no additional controls under the FFACO. While not required to achieve FFACO closure under the DQOs developed for CAU 107, the site is posted under 10 CFR 835 as a URMA, thereby further ensuring that an NTS worker will not receive a dose greater than $25 \mathrm{mrem} / \mathrm{yr}$. Based on the information presented above, data are adequate to support a closure option of no further action. 


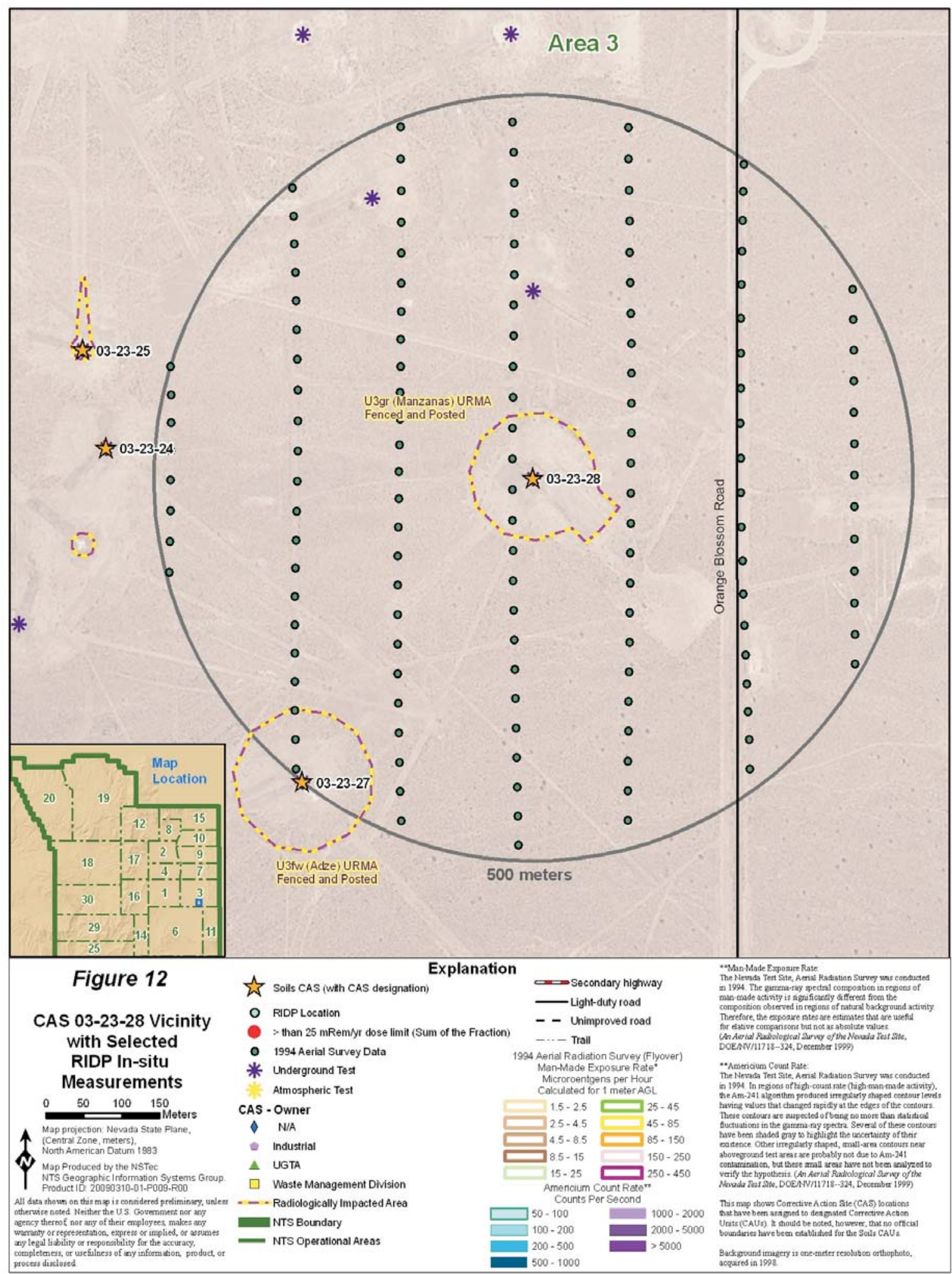

\section{FIGURE 12}




\subsection{CAS 03-23-29, Truchas-Chamisal Contamination AREa}

CAS 03-23-29 was designated to address potential surface soil contamination associated with the detonation and post-test drilling at the location of the TRUCHAS-CHAMISAL underground nuclear weapons detonation. REECo (1991) does not provide information about this site. The TRUCHAS-CHAMISAL detonation did not form a subsidence crater. The area is a potential crater and no stability study has been completed, so both access and future land use are limited. The TRUCHAS-CHAMISAL detonation cavity is part of the UGTA Sub-Project. This area is posted as a URMA, likely due to the deep underground source term that resulted from the nuclear test (BN, 2000).

\subsubsection{OPERATIONAL HiSTORY}

The TRUCHAS-CHAMISAL detonation, conducted on October 28, 1970, was part of Operation Emery. The test, detonated in emplacement hole U3ho, had a yield of less than $20 \mathrm{kt}$ (DOE/NV, 2000). Radiological contamination was suspected to be present at the surface from post-test pig pull operations. Pig pulls were similar to cable pulls, but instead of instruments being connected to the end of the cable, a sampling device called a pig was connected to the end of the cable. The pig was opened on site to collect sample material; therefore, the pig pull had a greater potential to cause surface contamination than either gas sampling or cable pulls. Stationary radiation monitors were placed in an arc around the surface ground zero of the test. The maximum gamma exposure rate measured by these monitors, $34 \mathrm{R} / \mathrm{hr}$, was collected during pig pull operations. A re-entry survey was conducted after the test, and the maximum exposure rate reading was 2 millirads per hour. The millirad unit indicates that both gamma- and beta-emitting radionuclides were present. Alpha contamination was also detected on the concrete pad and in soils near the surface ground zero (REECo, 1973a).

\subsubsection{RELEASE INFORMATION}

DOE/NV (1996) documented radiological releases from the detonation of TRUCHAS-CHAMISAL and from the subsequent pig pull. The releases included xenon-133, xenon-135, barium-140, and lanthanum-140. The xenon isotopes are gaseous radionuclides with short half-lives and are not suspected to be present in the soil. Barium and lanthanum are not gaseous; however, barium-140 has the longer half-life of 12 days (Nuclear Data Center, 2006). TRUCHAS-CHAMISAL is different from the other underground tests and detonations discussed in this SAFER Plan in that historical documentation indicates that low levels of surface contamination are present. In addition, a contaminated sheave used to extract the pig from the hole was also left on site (REECo, 1972).

\subsubsection{HistoricAL CHARACTERIZATION INFORMATION}

The following data were used to evaluate the potential surface release for CAS 03-23-29 and determine the likelihood of a release to surface soils in the area resulting from TRUCHAS-CHAMISAL. Historical operational data indicate that there is low-level surface contamination at this site. 


\subsubsection{Fly-Over Data}

The fly-over survey performed in 1994 does not show detectable levels of radionuclides in the area of this CAS and does not identify any nearby areas as ROIs (Hendricks and Riedhauser, 1999). The fly-over survey process is well established and has been used at many sites to make the "yes-no" type of decision used in this SAFER Plan (NNSA/NSO, 2005). The fly-over data have been used in a semi-quantitative way to support the conclusion made based on operational history that a widespread release to surface soils did not occur as a result of the TRUCHASCHAMISAL detonation or associated activities. There were 131 measurements collected within a 500-m radius of the TRUCHAS-CHAMISAL detonation (Figure 13). While the fly-over data, depicted in Figure 13, are shown as points, the field of view of the detector is large; thus, the flyover survey provided 100-percent coverage of this area. These data were analyzed as described in Proctor (1997) and Hendricks and Riedhauser (1999). The results of the analyzed survey data are shown in Table 30. All measurements were less than the detection limit of the instrumentation; however, these data only evaluate the potential for a widespread release and do not quantify the known, low-level point-source contamination at the site.

TABLE 30. CAS 03-23-29 Fly-OVER DATA SUMmary

\begin{tabular}{||l|c|c|c||}
\hline \hline MEASUREMENT TYPE & $\begin{array}{c}\text { NUMBER OF } \\
\text { MEASUREMENTS }\end{array}$ & $\begin{array}{c}\text { APPROXIMATE } \\
\text { DETECTION LIMIT }\end{array}$ & $\begin{array}{c}\text { NUMBER } \\
\text { MEASUREMENTS } \\
\text { >DETECTION LIMIT }\end{array}$ \\
\hline Total man-made & 131 & $1.5 \mathrm{microR} / \mathrm{hr}$ & 0 \\
\hline americium-241 & 131 & $50 \mathrm{cps}$ & 0 \\
\hline
\end{tabular}

The fly-over data presented above represent many individual measurements (referred to as point data), and each measurement is corrected for background radiation. The fly-over survey process continuously collects background radiation levels then corrects each measurement to remove it, resulting in data that show the added man-made radiation from testing or other activities. The fly-over measurements for total man-made radiation are very sensitive, with the detection limit of $1.5 \mathrm{microR} / \mathrm{hr}$. Typical background exposure rates are approximately $15 \mathrm{microR} / \mathrm{hr}$. Thus, the detection limit of $1.5 \mathrm{microR} / \mathrm{hr}$ results in detection of man-made radiation that is greater than approximately 10 percent of natural background radiation.

The fly-over surveys are very sensitive to americium-241. Americium-241 sensitivity is approximately $50 \mathrm{cps}$. A specific correlation to soil concentration values was not performed; however, a conservative correlation of $50 \mathrm{cps}$ to $300 \mathrm{nCi} / \mathrm{m}^{2}$ has been estimated by RSL based on other similar flights and the flight altitude of $200 \mathrm{ft}$. This value, $300 \mathrm{nCi} / \mathrm{m}^{2}$, was then compared to RIDP measurements made in non-operational areas of the NTS where no local releases of radioactive material occurred to determine whether the fly-over survey is capable of discerning levels of radioactivity indicative of a widespread radiological release. Since the RIDP values in the non-operational areas range from 24 to $573 \mathrm{nCi} / \mathrm{m}^{2}$ and the fly-over sensitivity is approximately $300 \mathrm{nCi} / \mathrm{m}^{2}$, this shows that the fly-over survey is capable of discerning where operational releases have occurred. No americium-241 fly-over survey measurements were greater than the detection limit, similar to the non-operational areas of the NTS. These data confirm that there was not a widespread release to surface soils. 


\subsubsection{Contaminated Land Report Data}

BN (2000) provides radiological survey results for this area. Measurements collected include exposure rate and FIDLER readings. Removable alpha and beta/gamma contamination were also assessed. Measurements were taken along the fence line that bounds the URMA. All measurements were consistent with background levels. The survey results show that contamination is not migrating outside the fenced URMA. Table 31 presents the results of these surveys (BN, 2000).

\section{TABle 31. CAS 03-23-29 CONTAMINATEd LAND SuRVey DATA Summary}

\begin{tabular}{|l|r|r|r|r|r||}
\hline $\begin{array}{c}\text { MEASUREMENT } \\
\text { TYPE }\end{array}$ & $\begin{array}{c}\text { NUMBER OF } \\
\text { MEASUREMENTS }\end{array}$ & $\begin{array}{c}\text { MAXIMUM } \\
\text { VALUE }\end{array}$ & $\begin{array}{c}\text { MINIMUM } \\
\text { VALUE }\end{array}$ & $\begin{array}{c}\text { AVERAGE } \\
\text { VALUE }\end{array}$ & $\begin{array}{c}\text { APPROXIMATE } \\
\text { INSTRUMENT } \\
\text { SENSITIVITY }\end{array}$ \\
\hline Removable Alpha & 6 & $0 \mathrm{dpm} / 100 \mathrm{~cm}^{2}$ & $0 \mathrm{dpm} / 100 \mathrm{~cm}^{2}$ & $0 \mathrm{dpm} / 100 \mathrm{~cm}^{2}$ & $5 \mathrm{dpm} / 100 \mathrm{~cm}^{2}$ \\
\hline Removable Beta & 6 & $5 \mathrm{dpm} / 100 \mathrm{~cm}^{2}$ & $0 \mathrm{dpm} / 100 \mathrm{~cm}^{2}$ & $1 \mathrm{dpm} / 100 \mathrm{~cm}^{2}$ & $16 \mathrm{dpm} / 100 \mathrm{~cm}^{2}$ \\
\hline Exposure Rate & 6 & $10 \mathrm{uR} / \mathrm{hr}$ & $10 \mathrm{uR} / \mathrm{hr}$ & $10 \mathrm{uR} / \mathrm{hr}$ & $20 \mathrm{uR} / \mathrm{hr}^{1}$ \\
\hline FIDLER & 6 & $90 \mathrm{cps}$ & $78 \mathrm{cps}$ & $83 \mathrm{cps}$ & $100 \mathrm{cps}$ \\
\hline \hline
\end{tabular}

Approximate Instrument Sensitivity is estimated based on typical background values and instrument performance. All values reported below the instrument sensitivity are estimates only.

All values were below detection limits. These ground-based survey data consist of measurements that are focused in the area of the CAS, thereby augmenting the wide-area data collected via fly-over surveys indicating that a widespread contaminant release did not occur and that the known historical contamination has not migrated outside of the potential crater area.

The NV/YMP RadCon Manual (NNSA/NSO, 2004b) is used at the NTS to implement the requirements set forth in $10 \mathrm{CFR} 835$. The manual allows for the release of areas from radiological controls when certain radiological limits are met. The limits were established as acceptable levels for use by the general public and, thus, are conservative given the ongoing controls at CAS 03-23-29 and the lack of both public and worker access to the site. Table 32 outlines these release values. BN (2000) survey measurements in the area of CAS 03-23-29 are well below the radiological control limits outlined in Table 32.

\subsubsection{3 $\underline{\text { RIDP Data }}$}

The RIDP did not include the area of this CAS because radiological contamination was not suspected in this area (DRI, 2007). No RIDP measurements were used to evaluate this CAS. 
TABle 32. Surface CONTAMination Release VALUES ${ }^{1}$ IN DPM/100 CM$^{2}$

\begin{tabular}{||l|l|l||}
\hline \multicolumn{1}{|c|}{ RADIONUCLIDE } & \multicolumn{1}{|c||}{ REMOVABLE $^{2,4}$} & $\begin{array}{c}\text { TOTAL (FIXED } \\
+ \text { REMOVABLE }^{2,3}\end{array}$ \\
\hline $\begin{array}{l}\text { natural uranium, uranium-235, uranium-238, and associated decay } \\
\text { products }\end{array}$ & $1,000^{7}$ & $5,000^{7}$ \\
\hline $\begin{array}{l}\text { transuranics, radium-226, radium-228, thorium-230, thorium-228, } \\
\text { protactinium-231, actinium-227, iodine-125, and iodine-129 }\end{array}$ & 20 & 500 \\
\hline $\begin{array}{l}\text { natural thorium, thorium-232, strontium-90, radium-223, radium- } \\
\text { 224, uranium-232, iodine-126, iodine-131, and iodine-133 }\end{array}$ & 200 & 1,000 \\
\hline $\begin{array}{l}\text { beta-gamma emitters (nuclides with decay modes other than alpha } \\
\text { emission or spontaneous fission), except strontium-90 and others } \\
\text { noted above }\end{array}$ & 1,000 & 5,000 \\
\hline tritium and tritiated compounds $^{6}$ & 10,000 & N/A \\
\hline
\end{tabular}

1 The values in this table, with the exception noted in footnote 5 , apply to radioactive contamination deposited on, but not incorporated into the interior or matrix of, the contaminated item. Where surface contamination by both alpha- and beta-gamma-emitting nuclides exists, the limits established for alpha- and beta-gamma-emitting nuclides apply independently.

2 As used in this table, dpm (disintegrations per minute) means the rate of emission by radioactive material as determined by correcting the counts per minute observed by an appropriate detector for background, efficiency, and geometric factors associated with the instrumentation.

3 The levels may be averaged over 1 square meter provided the maximum surface activity in any area of $100 \mathrm{~cm}^{2}$ is less than three times the value specified. For purposes of averaging, any square meter of surface shall be considered to be above the surface contamination value if: (1) From measurements of a representative number of sections it is determined that the average contamination level exceeds the applicable value; or (2) it is determined that the sum of the activity of all isolated spots or particles in any $100 \mathrm{~cm}^{2}$ area exceeds three times the applicable value.

4 The amount of removable radioactive material per $100 \mathrm{~cm}^{2}$ of surface area should be determined by swiping the area with dry filter or soft absorbent paper, applying moderate pressure, and then assessing the amount of radioactive material on the swipe with an appropriate instrument of known efficiency. (Note: The use of dry material may not be appropriate for tritium.) When removable contamination on objects of surface area less than $100 \mathrm{~cm}^{2}$ is determined, the activity per unit area shall be based on the actual area and the entire surface shall be wiped. It is not necessary to use swiping techniques to measure removable contamination levels if direct scan surveys indicate that the total residual surface contamination levels are within the limits for removable contamination.

5 This category of radionuclides includes mixed fission products, including the strontium-90 present in them. It does not apply to strontium-90 which has been separated from the other fission products or mixtures where the strontium-90 has been enriched.

6 Tritium contamination may diffuse into the volume or matrix of materials. Evaluation of surface contamination shall consider the extent to which such contamination may migrate to the surface in order to ensure the surface contamination value provided in this appendix is not exceeded. Once this contamination migrates to the surface, it may be removable, not fixed; therefore, a "Total" value does not apply.

7 (alpha)

\subsubsection{CONCLUSION}

TRUCHAS-CHAMISAL was an underground detonation with associated post-test pig pull operations. The detonation cavity is part of the UGTA Sub-Project. Data presented above show that no widespread release to surface soils that could cause an NTS worker dose greater than $25 \mathrm{mrem} / \mathrm{yr}$ occurred; therefore, data are adequate to support a closure option of closure in place with administrative controls. Historical evidence indicates that there is limited contamination within the potential crater area of the TRUCHAS-CHAMISAL detonation both on the concrete pad and on the sheave. However, the stability of the potential crater area is uncertain and these areas are currently assumed to be unsafe for entry.

The site is currently posted in compliance with 10 CFR 835 as a URMA. Contamination levels along this boundary are below the levels specified in Table 32, and contamination is not migrating outside the potential crater area (BN, 2000). A UR will be implemented that encompasses the potential crater area, including the concrete pad. The UR is an adequate administrative control to limit site access and worker dose. 


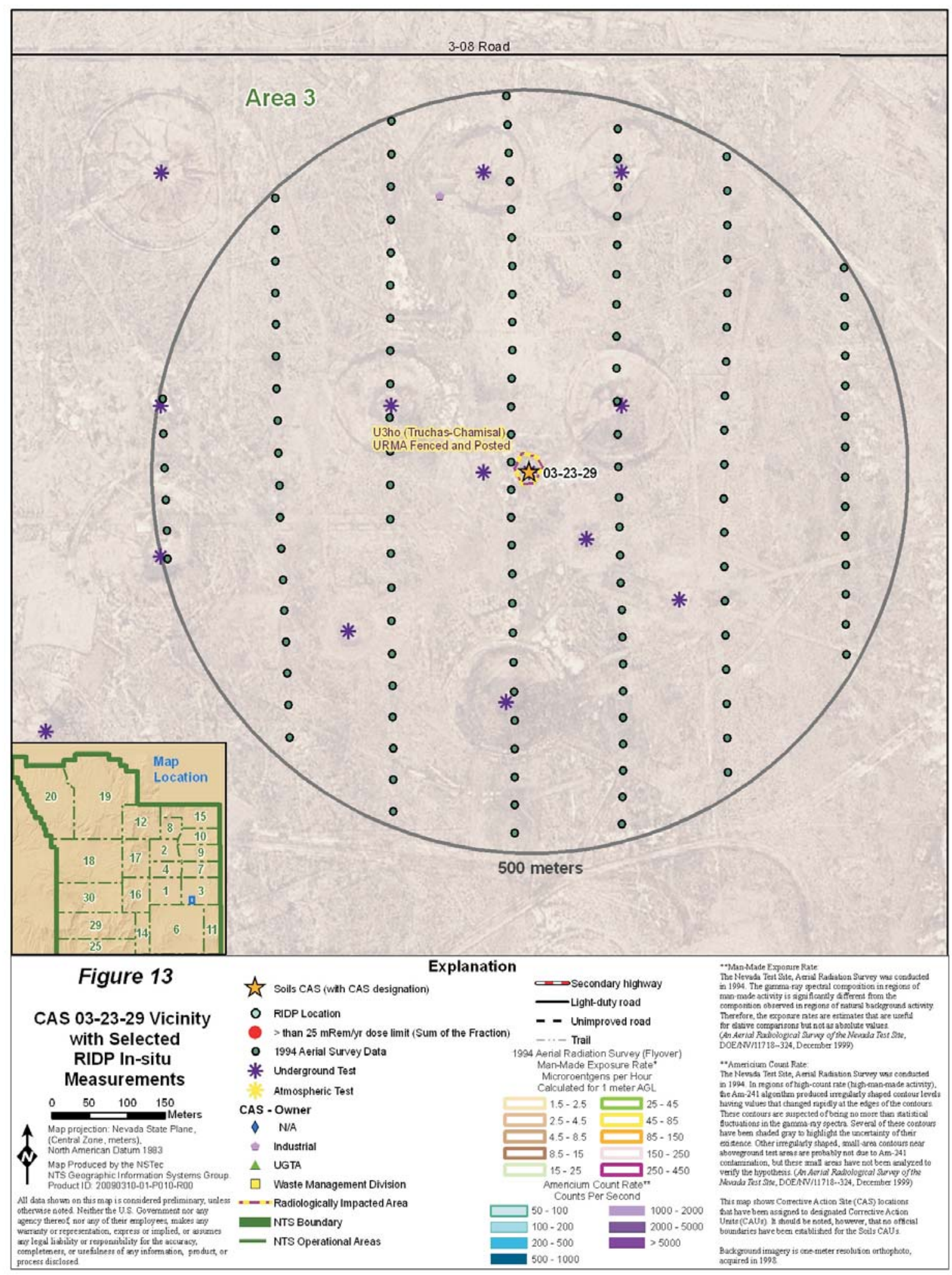

FIGURE 13 


\subsection{CAS 04-23-02, Atmospheric Test Site T4-A}

CAS 04-23-02 was designated to address potential surface soil contamination associated with the RAY atmospheric nuclear weapons test. This test was detonated from a tower (DOE/NV, 2000). CAS 04-23-02 is identified only by the FFACO listing of the geographical coordinates for the RAY atmospheric test. There are no fenced areas or radiological postings to identify the site. REECo (1991) does not provide information about this site. Field visits were conducted on January 23, 1996, and April 18, 2006. The 1996 site visit report noted that a 25- by 25-ft concrete slab partially obscured by soil and gravel exists at the CAS location. The slab has a partially broken steel anchor present. During the 2006 site visit, there were no fencing or postings, and a marker was placed to identify the site.

\subsubsection{OPERATIONAL HISTORY}

The RAY test, conducted on April 11, 1953, was part of Operation Upshot Knothole. The test was a lower-yield test of 200 tons. The radiological safety report, documenting radiological conditions during the test, states that a well-defined plume migrated south over the area now occupied by the Big Explosives Experimental Facility (AEC, 1953). Contaminant plume dispersion in a lateral (east-to-west) direction was not noted in the report (AEC, 1953).

\subsubsection{RELEASE INFORMATION}

DOE/NV (1996) does not provide documentation for nuclear weapons tests conducted during this time period. As noted above, AEC (1953) documented a release of radiological contamination that dispersed in a straight, narrow path to the south.

\subsubsection{HiSTORICAL CHARACTERIZATION INFORMATION}

A review of historical release information indicates that this area is within the contiguous contaminant plume from the FOX, NANCY, APPLE 1, and KEPLER tests, which are associated with CAS 04-23-01. The contaminant plume resulting from the RAY test, if still detectable, should be to the south of the detonation site based on historical operational data. However, there is no detectable contaminant plume that is consistent with this operational history. Thus, the low levels of radiological contamination detected in this area are not attributable to the RAY test but are related to the contamination extent of CAS 04-23-01, which will be addressed with a future CAU closure. However, available data are presented below to informally indicate the potential NTS worker dose in the area.

\subsubsection{Fly-Over Data}

The fly-over survey performed in 1994 shows low levels of detectable radioactivity (Hendricks and Riedhauser, 1999). This CAS is located within the contaminant extent from the FOX, NANCY, APPLE 1, and KEPLER tests, which are associated with CAS 04-23-01, and which will be addressed with a future CAU closure. There were 131 measurements collected within a 500-m radius of the surface ground zero of the RAY detonation (Figure 14). While the fly-over data, depicted in Figure 14, are shown as points, the field of view of the detector is large; thus, the fly-over survey provided 100-percent coverage of this area. These data were analyzed as described in Proctor (1997) and Hendricks and Riedhauser (1999). The results of the analyzed survey data are shown in Table 33. 
All measurements for americium-241 were below the detection limit, and 91 measurements for total man-made radioactivity were greater than the detection limit. These measurements were made in the known, contiguous contaminant plume of CAS 04-23-01, and this area will be addressed with a future CAU closure.

TABLE 33. CAS 04-23-02 Fly-OVER DATA SUMMARY

\begin{tabular}{|l|c|c|c|}
\hline MEASUREMENT TYPE & $\begin{array}{c}\text { NUMBER OF } \\
\text { MEASUREMENTS }\end{array}$ & $\begin{array}{c}\text { APPROXIMATE } \\
\text { DETECTION LIMIT }\end{array}$ & $\begin{array}{c}\text { NUMBER } \\
\text { MEASUREMENTS } \\
\text { >DETECTION LIMIT }\end{array}$ \\
\hline Total man-made & 131 & $1.5 \mathrm{microR} / \mathrm{hr}$ & 91 \\
\hline americium-241 & 131 & $50 \mathrm{cps}$ & 0 \\
\hline
\end{tabular}

The fly-over data presented above represent many individual measurements (referred to as point data), and each measurement is corrected for background radiation. The fly-over survey process continuously collects background radiation levels then corrects each measurement to remove it, resulting in data that show the added man-made radiation from testing or other activities. The fly-over measurements for total man-made radiation are very sensitive, with the detection limit of $1.5 \mathrm{microR} / \mathrm{hr}$. Typical background exposure rates are approximately $15 \mathrm{microR} / \mathrm{hr}$. Thus, the detection limit of $1.5 \mathrm{microR} / \mathrm{hr}$ results in detection of man-made radiation that is greater than approximately 10 percent of natural background radiation.

The fly-over surveys are very sensitive to americium-241. Americium-241 sensitivity is approximately $50 \mathrm{cps}$. A specific correlation to soil concentration values was not performed; however, a conservative correlation of $50 \mathrm{cps}$ to $300 \mathrm{nCi} / \mathrm{m}^{2}$ has been estimated by RSL based on other similar flights and the flight altitude of $200 \mathrm{ft}$. This value, $300 \mathrm{nCi} / \mathrm{m}^{2}$, was then compared to RIDP measurements made in non-operational areas of the NTS where no local releases of radioactive material occurred to determine whether the fly-over survey is capable of discerning levels of radioactivity indicative of a widespread radiological release. Since the RIDP values in the non-operational areas range from 24 to $573 \mathrm{nCi} / \mathrm{m}^{2}$ and the fly-over sensitivity is approximately $300 \mathrm{nCi} / \mathrm{m}^{2}$, this shows that the fly-over survey is capable of discerning where operational releases have occurred. No americium-241 fly-over survey measurements were greater than the detection limit, similar to the non-operational areas of the NTS. These data confirm that there was not a widespread release to surface soils.

\subsubsection{Contaminated Land Report Data}

Radiological surveys conducted for BN (2000) did not include this CAS location because the area is not controlled for radiological purposes due to the low levels of contamination.

\subsubsection{3 $\quad \underline{\text { RIDP Data }}$}

RIDP measurements were collected in the immediate vicinity of the CAS to characterize the extent of the plume from the KEPLER test (McArthur and Kordas, 1985) (Figure 14). RIDP measurements taken within $500 \mathrm{~m}$ of the RAY site were evaluated against limits set forth in Anspaugh and Daniels (1995) as explained in Section 2.2.4.3 of this SAFER Plan. Table 34 provides the maximum, minimum, and average values of these data and compares the maximum value to the limits set forth in Anspaugh and Daniels (1995). All values are well below these limits. This evaluation is not intended as a formal dose assessment but as a means by which these data may be compared to evaluate the validity of the operational history release assumptions. 
TABLE 34. CAS 04-23-02 RIDP DATA SUMMARY

\begin{tabular}{|l|r|r|r|r|r||}
\hline RADIONUCLIDE & $\begin{array}{c}\text { NUMBER OF } \\
\text { MEASUREMENTS }\end{array}$ & $\begin{array}{c}\text { MAXIMUM } \\
\text { VALUE } \\
\left(\mathrm{nCi} / \mathrm{m}^{2}\right)\end{array}$ & $\begin{array}{c}\text { MINIMUM } \\
\text { VALUE } \\
\left(\mathrm{nCi} / \mathrm{m}^{2}\right)\end{array}$ & $\begin{array}{c}\text { AVERAGE } \\
\text { VALUE } \\
\left(\mathrm{nCi} / \mathrm{m}^{2}\right)\end{array}$ & $\begin{array}{l}\text { MAX VALUE } \\
\text { FRACTION OF } \\
\text { DCG }\end{array}$ \\
\hline americium-241 & 10 & 52.67 & 29.11 & 36.67 & 0.02 \\
\hline cobalt-60 & 10 & 1.76 & 0.48 & 0.82 & 0.00 \\
\hline cesium-137 & 10 & 1745.49 & 37.81 & 340.23 & 0.54 \\
\hline europium-152 & 10 & 172.46 & 11.11 & 47.42 & 0.10 \\
\hline europium -154 & 10 & 29.62 & 8.99 & 13.49 & 0.02 \\
\hline europium -155 & 10 & 1.27 & 0.60 & 0.79 & 0.00 \\
\hline plutonium-238 & 10 & 89.26 & 49.29 & 62.14 & 0.02 \\
\hline plutonium -239 & 10 & 327.74 & 181.17 & 228.22 & 0.06 \\
\hline strontium-90 & 10 & 2208.29 & 47.84 & 430.43 & 0.01 \\
\hline
\end{tabular}

The slightly elevated RIDP measurements were collected within the larger known contaminant plume associated with the FOX, NANCY, APPLE 1, and KEPLER tests. Therefore, these results support the process knowledge and fly-over data.

\subsubsection{CONCLUSION}

The RAY test was a lower-yield atmospheric test detonated from a tower. Fly-over data indicate there is no longer a detectable contaminant plume that is consistent with operational history. The low levels of radiological contamination present near the site are not attributable to the RAY detonation but are associated with the FOX, NANCY, APPLE 1, and KEPLER tests, which will be addressed with a future CAU closure (Figure 7). This is supported by process knowledge, 100-percent coverage fly-over survey data, and RIDP data. Therefore, there is no credible exposure pathway that could cause an NTS worker to receive a dose greater than $25 \mathrm{mrem} / \mathrm{yr}$ at this CAS.

This CAS requires no additional controls under the FFACO. Based on the information presented above, data are adequate to support a closure option of no further action. 


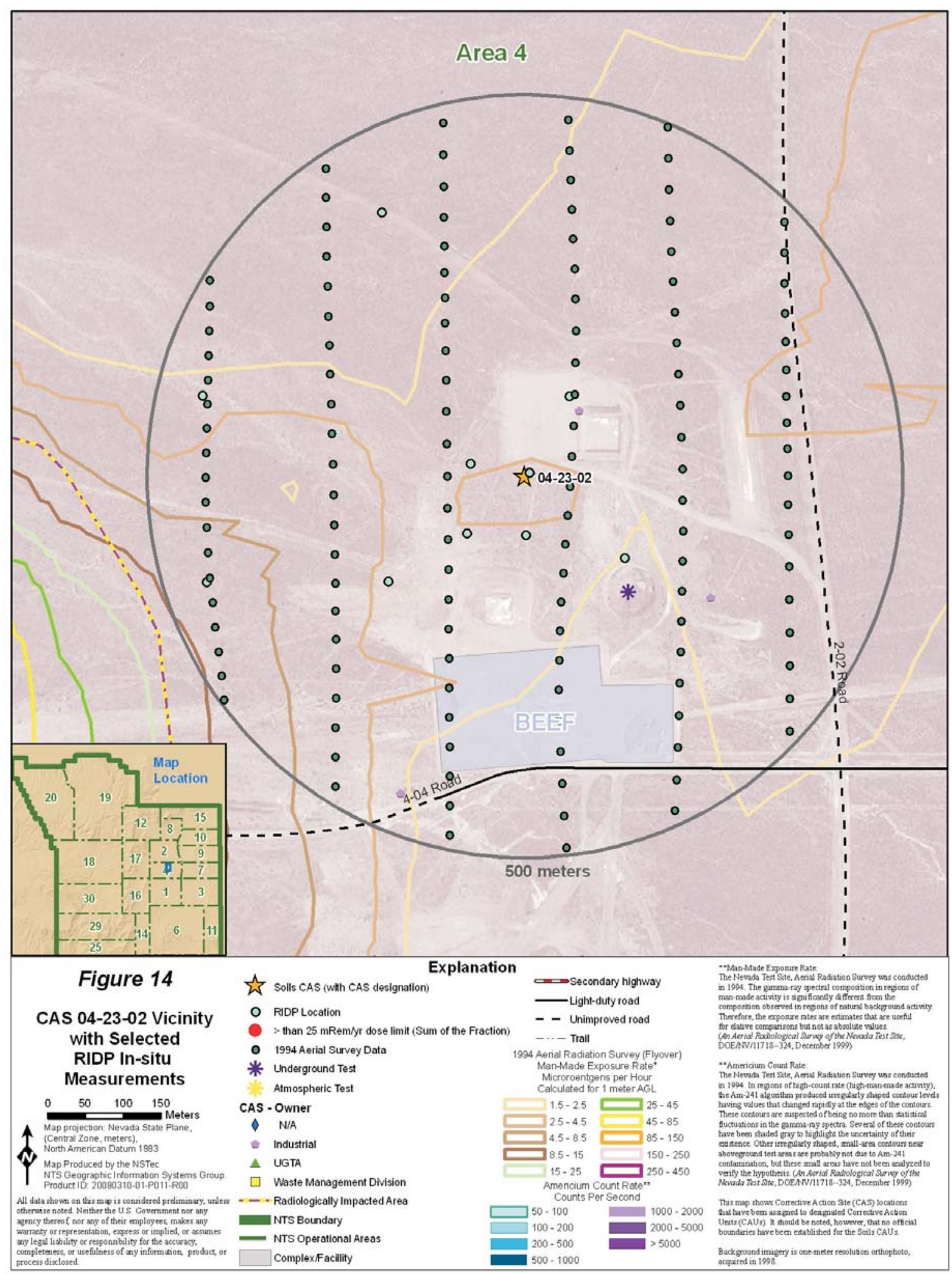

\section{FIGURE 14}




\subsection{CAS 05-23-06, ATMOSPHERIC TeSt Site}

CAS 05-23-06 was designated to address potential surface soil contamination associated with the ABLE, BAKER, BAKER-2, EASY, and FOX nuclear weapons tests. These atmospheric tests were detonated at more than $984 \mathrm{ft}$ above ground level (Los Alamos National Laboratory, 1951). The ground zero location for the tests associated with this CAS was determined through visual observations of the fireball at the time of detonation. These observations placed the ground zero 9,843 ft to the northwest of the current FFACO location, off the playa, near the "Kay Blockhouse," formerly known as "Alpha Blockhouse." A historical report states, "A red reference light was placed at ground zero in the center of the target. During the drop, all lights were turned off thirty seconds prior to burst time. Directly under ground zero, workers built a blast-proof alpha-recording shelter or blockhouse" (DoD, 1982). Origins of the Nevada Test Site provides a re-print of a hand-drawn map showing the "detector and target light array" and the Alpha Blockhouse with a single coordinate location (DOE, 2000). This structure was built at the Ranger target ground zero to house instrumentation for the test series. The Kay Blockhouse itself is a closed Industrial Sites CAS (CAS 05-33-01 in CAU 204).

Additionally, the Corrective Action Investigation Plan (CAIP) for CAU 204 states:

The site consists of the Kay Blockhouse and numerous burn pits and disturbed areas. The site was identified in the 1992 REECo Contaminated Areas Report I (Sorom, 1992). Various historical documents and drawings have identified CAS 05-33-01 by the following names: Kay Blockhouse, Kay Bunker, Ranger Blockhouse, and Alpha Blockhouse.

The Kay Blockhouse was originally constructed in 1951 for Operation Ranger, a series of five air drops (atmospheric nuclear tests) conducted from January 27 to February 6, 1951. These tests were detonated over the Kay Blockhouse, where reaction history, fireball and neutron and gamma-ray measurements were taken. (U.S. Department of Energy, National Nuclear Security Administration Nevada Operations Office [NNSA/NV], 2002)

Based on these historical information sources, the actual location of CAS 05-23-06 is the Kay Blockhouse and the surrounding area, which was previously closed as an Industrial Site.

\subsubsection{OPERATIONAL HISTORY}

The ABLE, BAKER, BAKER-2, EASY, and FOX tests were part of Operation Ranger. ABLE was a 1-kt test detonated on January 27, 1951; BAKER was an 8-kt test detonated on January 28, 1951; BAKER-2 was an 8-kt test detonated on February 2, 1951; EASY was a 1-kt test detonated on February 1, 1951; and FOX was a 22-kt test detonated on February 6, 1951. The devices were detonated well above the ground surface. These five tests, the first nuclear tests conducted at the NTS, were weapons-related air-drop experiments (DOE/NV, 2000).

\subsubsection{RELEASE INFORMATION}

The Operation Ranger tests caused a radiological release to the air space above the NTS. However, process knowledge and operational history strongly indicate these tests did not cause radiological contamination of surface soils within the boundaries of the NTS. Surface radiological contamination produced by a nuclear test conducted close to ground surface is largely from materials being drawn into the resulting radioactive cloud (DNA, 1981). Since 
these tests were detonated at more than $984 \mathrm{ft}$ above ground level, this process did not occur. Historical information indicates that neutron activation occurred from the Operation Ranger tests. Use of the Kay Blockhouse was limited for several years after the tests due to radiation levels associated with sodium-22. Sodium-22 has a half-life of 2.6 years (Nuclear Data Center, 2006). Soil activation was not noted as a contributor to these radiation levels (NNSA/NV, 2002).

\subsubsection{HistoricAL CHARACTERIZATION INFORMATION}

The CAU 204 Corrective Action Decision Document (NNSA/NSO, 2004a) reports the results of sampling conducted in accordance with the CAU 204 CAIP. The characterization activities included the surface ground zero location of the Operation Ranger tests. Results indicated the presence of depleted uranium (DU) above the preliminary action levels. DU contamination is not associated with Operation Ranger activities. The CAU 204 Closure Report (NNSA/NSO, 2006a) documents closure activities in the area, which included extending the RMA and implementing a FFACO UR encompassing the area. The following data were used to evaluate the potential surface release for CAS 05-23-06 and were used to determine if the existing FFACO UR is appropriate for this CAS.

\subsubsection{Fly-Over Data}

The fly-over survey performed in 1994 does not show detectable levels of radionuclides in the area of this CAS and does not identify any nearby areas as ROIs (Hendricks and Riedhauser, 1999). The fly-over survey process is well established and has been used at many sites to make the "yes-no" type of decision used in this SAFER Plan (NNSA/NSO, 2005). The fly-over data have been used in a semi-quantitative way to support the conclusion made based on operational history that a release to surface soils did not occur as a result of Operation Ranger detonations. There were 132 measurements collected within a 500-m radius of the Operation Ranger detonations (Figure 15). While the fly-over data, depicted in Figure 15, are shown as points, the field of view of the detector is large; thus, the fly-over survey provided 100-percent coverage of this area. These data were analyzed as described in Proctor (1997) and Hendricks and Riedhauser (1999). The results of the analyzed survey data are shown in Table 35. All measurements were less than the detection limit of the instrumentation.

TABle 35. CAS 05-23-06 Fly-OVEr DATA SuMMARY

\begin{tabular}{|l|c|c|c|}
\hline MEASUREMENT TYPE & $\begin{array}{c}\text { NUMBER OF } \\
\text { MEASUREMENTS }\end{array}$ & $\begin{array}{c}\text { APPROXIMATE } \\
\text { DETECTION LIMIT }\end{array}$ & $\begin{array}{c}\text { NUMBER } \\
\text { MEASUREMENTS } \\
\text { >DETECTION LIMIT }\end{array}$ \\
\hline Total man-made & 132 & $1.5 \mathrm{microR} / \mathrm{hr}$ & 0 \\
\hline americium-241 & 132 & $50 \mathrm{cps}$ & 0 \\
\hline
\end{tabular}

The fly-over data presented above represent many individual measurements (referred to as point data), and each measurement is corrected for background radiation. The fly-over survey process continuously collects background radiation levels then corrects each measurement to remove it, resulting in data that show the added man-made radiation from testing or other activities. The fly-over measurements for total man-made radiation are very sensitive, with the detection limit of $1.5 \mathrm{microR} / \mathrm{hr}$. Typical background exposure rates are approximately $15 \mathrm{microR} / \mathrm{hr}$. Thus, the detection limit of $1.5 \mathrm{microR} / \mathrm{hr}$ results in detection of man-made radiation that is greater than approximately 10 percent of natural background radiation. 
The fly-over surveys are very sensitive to americium-241. Americium-241 sensitivity is approximately $50 \mathrm{cps}$. A specific correlation to soil concentration values was not performed; however, a conservative correlation of $50 \mathrm{cps}$ to $300 \mathrm{nCi} / \mathrm{m}^{2}$ has been estimated by RSL based on other similar flights and the flight altitude of $200 \mathrm{ft}$. This value, $300 \mathrm{nCi} / \mathrm{m}^{2}$, was then compared to RIDP measurements made in non-operational areas of the NTS where no local releases of radioactive material occurred to determine whether the fly-over survey is capable of discerning levels of radioactivity indicative of a widespread radiological release. Since the RIDP values in the non-operational areas range from 24 to $573 \mathrm{nCi} / \mathrm{m}^{2}$ and the fly-over sensitivity is approximately $300 \mathrm{nCi} / \mathrm{m}^{2}$, this shows that the fly-over survey is capable of discerning where operational releases have occurred. No americium-241 fly-over survey measurements were greater than the detection limit, similar to the non-operational areas of the NTS. These data confirm that there was not a widespread release to surface soils.

\subsubsection{Contaminated Land Report Data}

Results of the surveys conducted in support of BN (2000) were used qualitatively to support the conclusions derived from the operational history. The surveys conducted for BN (2000) included radiological surveys within the current Kay Blockhouse RMA. Measurements collected included exposure rates and FIDLER readings. Removable alpha and beta/gamma contamination were also assessed. Table 36 presents the results of these surveys (BN, 2000).

TABLe 36. CAS 05-23-06 CONTAMINATEd LAND SURVEY DATA Summary

\begin{tabular}{|l|r|r|r|r|r|}
\hline $\begin{array}{c}\text { MeASUREMENT } \\
\text { TYPE }\end{array}$ & $\begin{array}{c}\text { NUMBER OF } \\
\text { MEASUREMENTS }\end{array}$ & $\begin{array}{c}\text { MAXIMUM } \\
\text { VALUE }\end{array}$ & $\begin{array}{c}\text { MINIMUM } \\
\text { VAlUE }\end{array}$ & $\begin{array}{c}\text { AVERAGE } \\
\text { VALUE }\end{array}$ & $\begin{array}{c}\text { APPROXIMATE } \\
\text { InSTRUMENT } \\
\text { SENSITIVITY }\end{array}$ \\
\hline Removable Alpha & 10 & $38 \mathrm{dpm} / 100 \mathrm{~cm}^{2}$ & $0 \mathrm{dpm} / 100 \mathrm{~cm}^{2}$ & $6.4 \mathrm{dpm} / 100 \mathrm{~cm}^{2}$ & $5 \mathrm{dpm} / 100 \mathrm{~cm}^{2}$ \\
\hline Removable Beta & 10 & $77 \mathrm{dpm} / 100 \mathrm{~cm}^{2}$ & $0 \mathrm{dpm} / 100 \mathrm{~cm}^{2}$ & $14 \mathrm{dpm} / 100 \mathrm{~cm}^{2}$ & $16 \mathrm{dpm} / 100 \mathrm{~cm}^{2}$ \\
\hline Exposure Rate & 10 & $30 \mathrm{uR} / \mathrm{hr}$ & $15 \mathrm{uR} / \mathrm{hr}$ & $21 \mathrm{uR} / \mathrm{hr}$ & $20 \mathrm{uR} / \mathrm{hr}^{1}$ \\
\hline FIDLER & 10 & $713 \mathrm{cps}$ & $100 \mathrm{cps}$ & $408 \mathrm{cps}$ & $100 \mathrm{cps}$ \\
\hline
\end{tabular}

${ }^{1}$ Approximate Instrument Sensitivity is estimated based on typical background values and instrument performance. All values reported below the instrument sensitivity are estimates only.

All values greater than detection limits were visually identified as DU shrapnel, which is not a contaminant of concern associated with Operation Ranger activities (BN, 2000). These ground-based survey data consist of measurements that are focused in the area of the CAS, thereby augmenting the wide-area data collected via fly-over surveys. These data provide an additional resource indicating that the current FFACO UR is appropriate for closure of CAS 05-23-06 and that a surface release to surface soils or significant soil activation did not occur.

The NV/YMP RadCon Manual (NNSA/NSO, 2004b) is used at the NTS to implement the requirements set forth in $10 \mathrm{CFR} 835$. The manual allows for the release of areas from radiological controls when certain radiological limits are met. The limits were established as acceptable levels for use by the general public and, thus, are conservative given the ongoing controls at CAS 05-23-06 and the lack of both public and worker access to the site. Table 37 outlines these release values. The maximum alpha value of $38 \mathrm{dpm} / 100 \mathrm{~cm}^{2}$ results from DU, not from transuranics, so BN (2000) survey measurements in the area of CAS 05-23-06 are well below the radiological control limits outlined in Table 37. 
TABle 37. Surface CONTAMination Release VALUES ${ }^{1}$ IN DPM/100 CM$^{2}$

\begin{tabular}{||l|l|l||}
\hline \multicolumn{1}{|c|}{ RADIONUCLIDE } & \multicolumn{1}{|c||}{ REMOVABLE $^{2,4}$} & $\begin{array}{c}\text { TOTAL (FIXED } \\
\text { +REMOVABLE) }\end{array}$ \\
\hline $\begin{array}{l}\text { natural uranium, uranium-235, uranium-238, and associated decay } \\
\text { products }\end{array}$ & $1,000^{7}$ & $5,000^{7}$ \\
\hline $\begin{array}{l}\text { transuranics, radium-226, radium-228, thorium-230, thorium-228, } \\
\text { protactinium-231, actinium-227, iodine-125, and iodine-129 }\end{array}$ & 20 & 500 \\
\hline $\begin{array}{l}\text { natural thorium, thorium-232, strontium-90, radium-223, radium- } \\
\text { 224, uranium-232, iodine-126, iodine-131, and iodine-133 }\end{array}$ & 200 & 1,000 \\
\hline $\begin{array}{l}\text { beta-gamma emitters (nuclides with decay modes other than alpha } \\
\text { emission or spontaneous fission), except strontium-90 and others } \\
\text { noted above }\end{array}$ & 1,000 & 5,000 \\
\hline tritium and tritiated compounds $^{6}$ & 10,000 & N/A \\
\hline
\end{tabular}

1 The values in this table, with the exception noted in footnote 5 , apply to radioactive contamination deposited on, but not incorporated into the interior or matrix of, the contaminated item. Where surface contamination by both alpha- and beta-gamma-emitting nuclides exists, the limits established for alpha- and beta-gamma-emitting nuclides apply independently.

2 As used in this table, dpm (disintegrations per minute) means the rate of emission by radioactive material as determined by correcting the counts per minute observed by an appropriate detector for background, efficiency, and geometric factors associated with the instrumentation.

3 The levels may be averaged over 1 square meter provided the maximum surface activity in any area of $100 \mathrm{~cm}^{2}$ is less than three times the value specified. For purposes of averaging, any square meter of surface shall be considered to be above the surface contamination value if: (1) From measurements of a representative number of sections it is determined that the average contamination level exceeds the applicable value; or (2) it is determined that the sum of the activity of all isolated spots or particles in any $100 \mathrm{~cm}^{2}$ area exceeds three times the applicable value.

4 The amount of removable radioactive material per $100 \mathrm{~cm}^{2}$ of surface area should be determined by swiping the area with dry filter or soft absorbent paper, applying moderate pressure, and then assessing the amount of radioactive material on the swipe with an appropriate instrument of known efficiency. (Note: The use of dry material may not be appropriate for tritium.) When removable contamination on objects of surface area less than $100 \mathrm{~cm}^{2}$ is determined, the activity per unit area shall be based on the actual area and the entire surface shall be wiped. It is not necessary to use swiping techniques to measure removable contamination levels if direct scan surveys indicate that the total residual surface contamination levels are within the limits for removable contamination.

5 This category of radionuclides includes mixed fission products, including the strontium- 90 present in them. It does not apply to strontium-90 which has been separated from the other fission products or mixtures where the strontium-90 has been enriched.

6 Tritium contamination may diffuse into the volume or matrix of materials. Evaluation of surface contamination shall consider the extent to which such contamination may migrate to the surface in order to ensure the surface contamination value provided in this appendix is not exceeded. Once this contamination migrates to the surface, it may be removable, not fixed; therefore, a "Total" value does not apply.

7 (alpha)

\subsubsection{3 $\underline{\text { RIDP Data }}$}

RIDP measurements were collected in the immediate vicinity of the CAS (McArthur and Kordas, 1985) (Figure 15). RIDP measurements taken within $500 \mathrm{~m}$ of the Operation Ranger site were evaluated against limits set forth in Anspaugh and Daniels (1995) as explained in Section 2.2.4.3 of this SAFER Plan. Table 38 provides the maximum, minimum, and average values of these data and compares the maximum value to the limits set forth in Anspaugh and Daniels (1995). All values are well below these limits. This evaluation is not intended as a formal dose assessment but demonstrates that the current FFACO UR is protective of NTS workers. 
TABLE 38. CAS 05-23-06 RIDP DATA SUMMARY

\begin{tabular}{|l|r|r|r|r|r||}
\hline RADIONUCLIDE & $\begin{array}{c}\text { NUMBER OF } \\
\text { MEASUREMENTS }\end{array}$ & $\begin{array}{c}\text { MAXIMUM } \\
\text { VALUE } \\
\left(\mathrm{nCi} / \mathrm{m}^{2}\right)\end{array}$ & $\begin{array}{c}\text { MINIMUM } \\
\text { VALUE } \\
\left(\mathrm{nCi} / \mathrm{m}^{2}\right)\end{array}$ & $\begin{array}{c}\text { AVERAGE } \\
\text { VALUE } \\
\left(\mathrm{nCi} / \mathrm{m}^{2}\right)\end{array}$ & $\begin{array}{l}\text { MAX VALUE } \\
\text { FACTION OF } \\
\text { DCG }\end{array}$ \\
\hline americium-241 & 23 & 38.90 & 31.41 & 35.12 & 0.02 \\
\hline cobalt-60 & 23 & 0.92 & 0.55 & 0.68 & 0.00 \\
\hline cesium-137 & 23 & 21.97 & 4.34 & 13.14 & 0.01 \\
\hline europium-152 & 23 & 515.19 & 26.15 & 169.70 & 0.29 \\
\hline europium -154 & 23 & 9.09 & 5.29 & 7.27 & 0.01 \\
\hline europium -155 & 23 & 1.29 & 1.04 & 1.18 & 0.00 \\
\hline plutonium-238 & 23 & 13.10 & 10.57 & 11.82 & 0.00 \\
\hline plutonium -239 & 23 & 371.34 & 299.81 & 335.19 & 0.07 \\
\hline strontium-90 & 23 & 18.44 & 3.65 & 11.03 & 0.00 \\
\hline
\end{tabular}

\subsubsection{CONCLUSION}

The detonations associated with CAS 05-23-06 occurred at approximately 1,000 ft amsl and did not cause surface radiological contamination at or near this CAS. This is supported by process knowledge, 100-percent coverage fly-over survey data, focused measurements provided by the Contaminated Land Report survey data, RIDP data, and data collected for CAU 204. The demonstrated lack of radiological releases to the surface soils in the vicinity of CAS 05-23-06 leads to the conclusion that there is no credible exposure pathway that could cause an NTS worker to receive a dose greater than $25 \mathrm{mrem} / \mathrm{yr}$ at this CAS.

This CAS requires no additional controls under the FFACO. While not required to achieve FFACO closure under the DQOs developed for CAU 107, the site is posted under 10 CFR 835 as an RMA. In addition, the CAU 204 UR is in place, thereby further ensuring that an NTS worker will not receive a dose greater than $25 \mathrm{mrem} / \mathrm{yr}$. Based on the information presented above, data are adequate to support a closure option of no further action. 


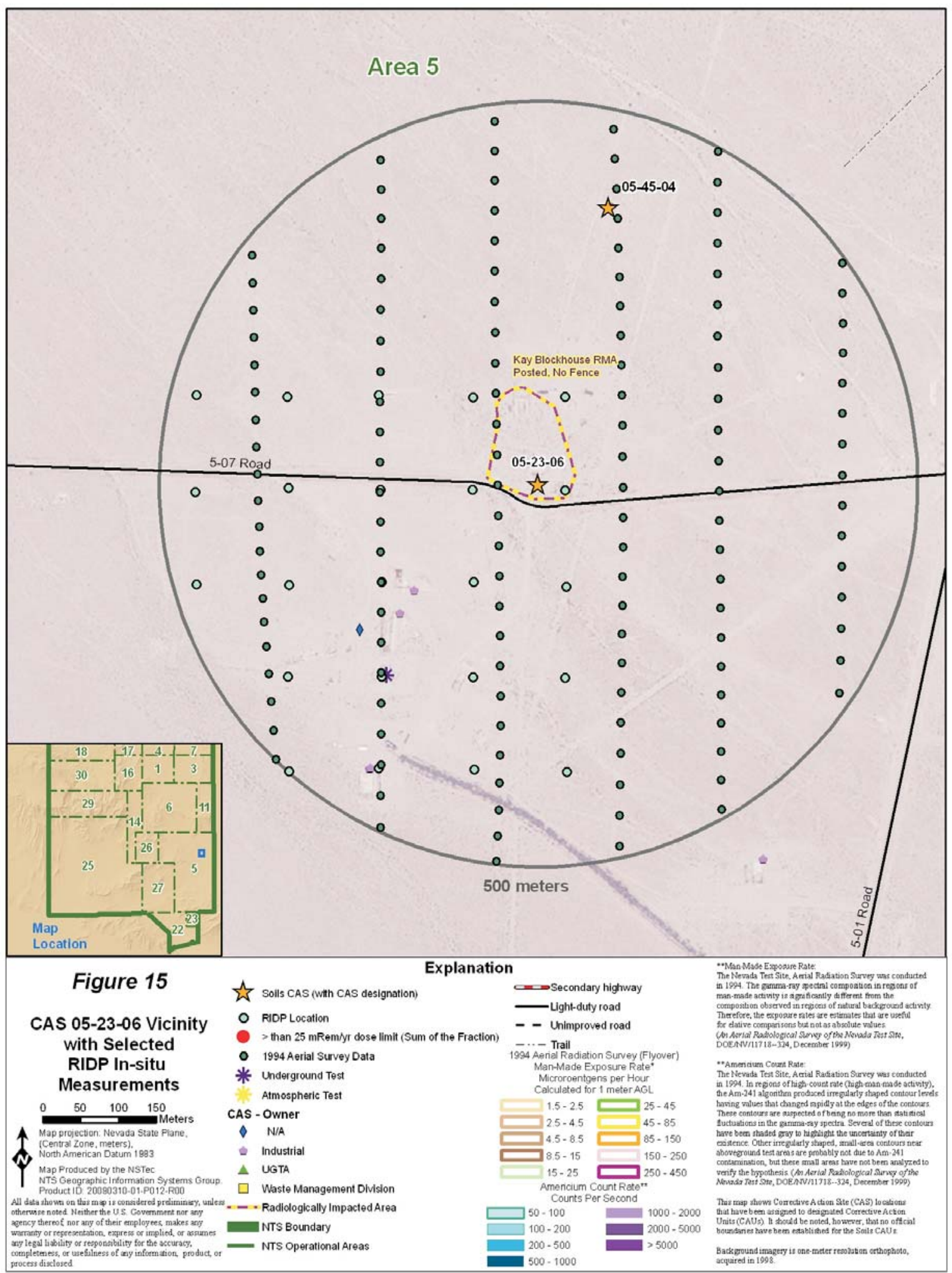

\section{FIGURE 15}




\subsection{CAS 09-23-06, Mound of Contaminated SoIL}

CAS 09-23-06 was designated to address potential surface soil contamination associated with post-test drilling near the location of the PITON-A underground nuclear weapons detonation. This CAS consists of a mound of soil that has been historically identified as radiologically contaminated. This mound is within a fenced area that is approximately 400 square feet $\left(\mathrm{ft}^{2}\right)$ in area. The entire area, including the mound, is controlled for radiological purposes and is posted as a URMA, most likely because of an abandoned injection well within the fenced area that historically received radiological and chemical effluent associated with other U-9 ITS Y-30 post-test drillbacks (NNSA/NSO, 2007b). The injection well was originally drilled as a post-test hole (U-9 ITS Y-30 PS \#1A). The injection well and fenced area together were identified as CAS 09-20-03 and were included in CAU 542. The CAS was investigated to determine if a surface release had occurred within the fenced area. During the investigation, no contaminants of concern were detected in soil samples collected within the fenced area. In addition, a radiological survey noted that no areas of elevated radioactivity were found within the fenced boundary. Based on the evidence that no surface release had occurred, the CAS was closed with no further action in 2007 (NNSA/NSO, 2007b).

The mound appears to be associated with the post-test drilling activities and may be native soil removed to excavate a cellar or to convert the borehole to an injection well (REECo, 1991). The CAS is located in a fenced and posted URMA, and there are numerous subsidence craters and potential subsidence craters in the vicinity. Therefore, both access and future land use are limited. The PITON-A detonation cavity itself is part of the UGTA Sub-Project.

\subsubsection{OPERATIONAL HISTORY}

The PITON-A detonation, conducted on May 28, 1970, was part of Operation Mandrel. The test, detonated in emplacement hole U-9 ITS Y-30, had a yield of less than $20 \mathrm{kt}$ (DOE/NV, 2000). Radiological contamination was suspected to be present from post-test drilling conducted at hole PS\#1A. PITON-A was detonated simultaneously with nearby PITON-B; therefore, readings collected by stationary radiation monitors cannot be directly associated with the PITON-A site.

\subsubsection{RELEASE INFORMATION}

DOE/NV (1996) documented a radiological release from the detonation of PITON-A; however, the release was masked by the larger release associated with PITON-C, which was detonated on the same day and in the same general area as PITON-A.

\subsubsection{HiSTORICAL CHARACTERIZATION INFORMATION}

CAS 09-20-03, an injection well surface release point in CAU 542, is located in the same fenced area as CAS 09-23-06. CAS 09-20-03 includes the entire fenced area and was investigated for evidence of a surface release within the fenced area from the injection well activities. The injection well historically received radiological and chemical effluent associated with other U-9 ITS Y-30 post-test drillbacks (NNSA/NSO, 2007b). In 2006, a walkover radiological survey was conducted inside the fenced area, and no areas with elevated radioactivity were identified. Soil samples were collected from CAS 09-20-03 near the unused injection well discharge pipe. Also, two samples were collected from outside the fenced area to determine background levels for gamma-emitting radionuclides. No analytes were detected at concentrations that exceeded final action levels, and the CAS was closed with no further action (NNSA/NSO, 2007b). 
The following data were used to evaluate the potential surface release for CAS 09-23-06 and determine the likelihood of a release to the surface soils in the area.

\subsubsection{Fly-Over Data}

The fly-over survey performed in 1994 shows detectable levels of radioactivity but does not identify the area as an ROI (Hendricks and Riedhauser, 1999). This CAS is located within the plume extents of the HOOD test, which is associated with CAS 09-23-14, and the CHARLESTON test, which is associated with CAS 09-99-01. The HOOD test had the highest yield of any atmospheric test conducted at the NTS (DOE/NV, 2000). Thus, the low levels of radiological contamination detected in this area are not attributable to the PITON-A detonation, but are related to the contamination extent of CASs 09-23-14 and 09-99-01, which will be addressed with a future CAU closure.

The fly-over survey process is well established and has been used at many sites to make the "yes-no" type of decision used in this SAFER Plan (NNSA/NSO, 2005). The fly-over data have been used in a semi-quantitative way to support the conclusion made based on operational history that a widespread release to surface soils did not occur as a result of PITON-A operations. There were 133 measurements collected within a $500-\mathrm{m}$ radius of the surface PITON-A detonation (Figure 16). While the fly-over data, depicted in Figure 16, are shown as points, the field of view of the detector is large; thus, the fly-over survey provided 100-percent coverage of this area. These data were analyzed as described in Proctor (1997) and Hendricks and Riedhauser (1999). The results of the analyzed survey data are shown in Table 39.

All measurements for americium-241 were below the detection limit, and 120 measurements for total man-made radioactivity were greater than the detection limit. These measurements were made in the known, contiguous contaminant plume extents of HOOD and CHARLESTON (CASs 09-23-14 and 09-99-01), which will be addressed with a future CAU closure.

\section{TABLe 39. CAS 09-23-06 Fly-OVER DATA SuMMARY}

\begin{tabular}{|l|c|c|c|}
\hline MEASUREMENT TYPE & $\begin{array}{c}\text { NUMBER OF } \\
\text { MEASUREMENTS }\end{array}$ & $\begin{array}{c}\text { APPROXIMATE } \\
\text { DETECTION LIMIT }\end{array}$ & $\begin{array}{c}\text { NUMBER } \\
\text { MEASUREMENTS } \\
\text { >DETECTION LIMIT }\end{array}$ \\
\hline Total man-made & 133 & $1.5 \mathrm{microR} / \mathrm{hr}$ & 120 \\
\hline americium-241 & 133 & $50 \mathrm{cps}$ & 0 \\
\hline
\end{tabular}

The fly-over data presented above represent many individual measurements (referred to as point data), and each measurement is corrected for background radiation. The fly-over survey process continuously collects background radiation levels then corrects each measurement to remove it, resulting in data that show the added man-made radiation from testing or other activities. The fly-over measurements for total man-made radiation are very sensitive, with the detection limit of $1.5 \mathrm{microR} / \mathrm{hr}$. Typical background exposure rates are approximately $15 \mathrm{microR} / \mathrm{hr}$. Thus, the detection limit of $1.5 \mathrm{microR} / \mathrm{hr}$ results in detection of man-made radiation that is greater than approximately 10 percent of natural background radiation.

The fly-over surveys are very sensitive to americium-241. Americium-241 sensitivity is approximately $50 \mathrm{cps}$. A specific correlation to soil concentration values was not performed; however, a conservative correlation of $50 \mathrm{cps}$ to $300 \mathrm{nCi} / \mathrm{m}^{2}$ has been estimated by RSL based on other similar flights and the flight altitude of $200 \mathrm{ft}$. This value, $300 \mathrm{nCi} / \mathrm{m}^{2}$, was then compared to RIDP measurements made in non-operational areas of the NTS where no local releases of 
radioactive material occurred to determine whether the fly-over survey is capable of discerning levels of radioactivity indicative of a widespread radiological release. Since the RIDP values in the non-operational areas range from 24 to $573 \mathrm{nCi} / \mathrm{m}^{2}$ and the fly-over sensitivity is approximately $300 \mathrm{nCi} / \mathrm{m}^{2}$, this shows that the fly-over survey is capable of discerning where operational releases have occurred. No americium-241 fly-over survey measurements were greater than the detection limit, similar to the non-operational areas of the NTS.

\subsubsection{Contaminated Land Report Data}

Results of the surveys conducted in support of BN (2000) were used qualitatively to support the conclusions derived from the operational history. The surveys conducted for BN (2000) included radiological surveys in the immediate area of CAS 09-23-06. Measurements collected included exposure rates and FIDLER readings. Removable alpha and beta/gamma contamination were also assessed. Measurements were collected within the boundaries of URMA and around the perimeter of these areas. Table 40 presents the results of these surveys (BN, 2000).

\section{TABLe 40. CAS 09-23-06 CONTAMinated LAND SuRVey DATA SUMMARY}

\begin{tabular}{||l|r|r|r|r|r||}
\hline $\begin{array}{c}\text { MeASUREMENT } \\
\text { TyPE }\end{array}$ & $\begin{array}{c}\text { Number OF } \\
\text { MEASUREMENTS }\end{array}$ & $\begin{array}{c}\text { MAXIMUM } \\
\text { VAluE }\end{array}$ & $\begin{array}{c}\text { Minimum } \\
\text { VALUE }\end{array}$ & $\begin{array}{c}\text { AVERAGE } \\
\text { VALUE }\end{array}$ & $\begin{array}{c}\text { APPROXIMATE } \\
\text { InSTRUMENT } \\
\text { SENSITIVITY }\end{array}$ \\
\hline Removable Alpha & 5 & $0 \mathrm{dpm} / 100 \mathrm{~cm}^{2}$ & $0 \mathrm{dpm} / 100 \mathrm{~cm}^{2}$ & $0 \mathrm{dpm} / 100 \mathrm{~cm}^{2}$ & $5 \mathrm{dpm} / 100 \mathrm{~cm}^{2}$ \\
\hline Removable Beta & 5 & $8 \mathrm{dpm} / 100 \mathrm{~cm}^{2}$ & $0 \mathrm{dpm} / 100 \mathrm{~cm}^{2}$ & $1.6 \mathrm{dpm} / 100 \mathrm{~cm}^{2}$ & $16 \mathrm{dpm} / 100 \mathrm{~cm}^{2}$ \\
\hline Exposure Rate & 5 & $10 \mathrm{uR} / \mathrm{hr}$ & $10 \mathrm{uR} / \mathrm{hr}$ & $10 \mathrm{uR} / \mathrm{hr}$ & $20 \mathrm{uR} / \mathrm{hr}^{1}$ \\
\hline FIDLER & 5 & $50 \mathrm{cps}$ & $40 \mathrm{cps}$ & $43 \mathrm{cps}$ & $100 \mathrm{cps}$ \\
\hline
\end{tabular}

${ }^{1}$ Approximate Instrument Sensitivity is estimated based on typical background values and instrument performance. All values reported below the instrument sensitivity are estimates only.

All values were below detection limits. These ground-based survey data consist of measurements that are focused in the post-test drilling areas in and around the URMAs and the suspect mound thereby augmenting the wide-area data collected via fly-over surveys. These data provide an additional resource indicating that post-test drilling operations did not lead to surface soil contamination.

The NV/YMP RadCon Manual (NNSA/NSO, 2004b) is used at the NTS to implement the requirements set forth in 10 CFR 835 . The manual allows for the release of areas from radiological controls when certain radiological limits are met. The limits were established as acceptable levels for use by the general public and, thus, are conservative given the ongoing controls at CAS 09-23-06 and the lack of both public and worker access to the site. Table 41 outlines these release values. BN (2000) survey measurements in the area of CAS 09-23-06 are well below the radiological control limits outlined in Table 41.

\subsubsection{3 $\underline{\text { RIDP Data }}$}

Several RIDP measurements were taken within $500 \mathrm{~m}$ of the PITON-A site (Figure 16). RIDP values were used to evaluate operational history and support the conclusion that the elevated exposure rate readings observed during the drilling operations did not indicate a widespread contaminant release from PITON-A operations. RIDP measurements taken within $500 \mathrm{~m}$ of the PITON-A site were evaluated against limits set forth in Anspaugh and Daniels (1995) as explained in Section 2.2.4.3 of this SAFER Plan. Table 42 provides the maximum, minimum, and average values of these data and compares the maximum value to the limits set forth in Anspaugh and Daniels (1995). All values are well below these limits. 


\section{TAble 41. Surface Contamination Release VALUES ${ }^{1}$ IN DPM/100 CM$^{2}$}

\begin{tabular}{||l|l|l||}
\hline \multicolumn{1}{|c|}{ RADIONUCLIDE } & REMOVABLE $^{2,4}$ & $\begin{array}{c}\text { TOTAL (FIXED } \\
\text { +REMOVABLE) }\end{array}$ \\
\hline $\begin{array}{l}\text { natural uranium, uranium-235, uranium-238, and associated decay } \\
\text { products }\end{array}$ & $1,000^{7}$ & $5,000^{7}$ \\
\hline $\begin{array}{l}\text { transuranics, radium-226, radium-228, thorium-230, thorium-228, } \\
\text { protactinium-231, actinium-227, iodine-125, and iodine-129 }\end{array}$ & 20 & 500 \\
\hline $\begin{array}{l}\text { natural thorium, thorium-232, strontium-90, radium-223, radium-224, } \\
\text { uranium-232, iodine-126, iodine-131, and iodine-133 }\end{array}$ & 200 & 1,000 \\
\hline $\begin{array}{l}\text { beta-gamma emitters (nuclides with decay modes other than alpha } \\
\text { emission or spontaneous fission), except strontium-90 and others } \\
\text { noted above }\end{array}$ & 1,000 & 5,000 \\
\hline tritium and tritiated compounds $^{6}$ & 10,000 & N/A \\
\hline
\end{tabular}

1 The values in this table, with the exception noted in footnote 5, apply to radioactive contamination deposited on, but not incorporated into the interior or matrix of, the contaminated item. Where surface contamination by both alpha- and beta-gamma-emitting nuclides exists, the limits established for alpha- and beta-gamma-emitting nuclides apply independently.

2 As used in this table, dpm (disintegrations per minute) means the rate of emission by radioactive material as determined by correcting the counts per minute observed by an appropriate detector for background, efficiency, and geometric factors associated with the instrumentation.

3 The levels may be averaged over 1 square meter provided the maximum surface activity in any area of $100 \mathrm{~cm}^{2}$ is less than three times the value specified. For purposes of averaging, any square meter of surface shall be considered to be above the surface contamination value if: (1) From measurements of a representative number of sections it is determined that the average contamination level exceeds the applicable value; or (2) it is determined that the sum of the activity of all isolated spots or particles in any $100 \mathrm{~cm}^{2}$ area exceeds three times the applicable value.

4 The amount of removable radioactive material per $100 \mathrm{~cm}^{2}$ of surface area should be determined by swiping the area with dry filter or soft absorbent paper, applying moderate pressure, and then assessing the amount of radioactive material on the swipe with an appropriate instrument of known efficiency. (Note: The use of dry material may not be appropriate for tritium.) When removable contamination on objects of surface area less than $100 \mathrm{~cm}^{2}$ is determined, the activity per unit area shall be based on the actual area and the entire surface shall be wiped. It is not necessary to use swiping techniques to measure removable contamination levels if direct scan surveys indicate that the total residual surface contamination levels are within the limits for removable contamination.

5 This category of radionuclides includes mixed fission products, including the strontium-90 present in them. It does not apply to strontium-90 which has been separated from the other fission products or mixtures where the strontium-90 has been enriched.

6 Tritium contamination may diffuse into the volume or matrix of materials. Evaluation of surface contamination shall consider the extent to which such contamination may migrate to the surface in order to ensure the surface contamination value provided in this appendix is not exceeded. Once this contamination migrates to the surface, it may be removable, not fixed; therefore, a "Total" value does not apply.

7 (alpha)

TABLE 42. CAS 09-23-06 RIDP DATA SUMMARY

\begin{tabular}{|l|r|r|r|r|r||}
\hline RADIONUCLIDE & $\begin{array}{c}\text { NUMBER OF } \\
\text { MEASUREMENTS }\end{array}$ & $\begin{array}{c}\text { MAXIMUM } \\
\text { VALUE } \\
\left(\mathrm{nCi} / \mathrm{m}^{2}\right)\end{array}$ & $\begin{array}{c}\text { MINIMUM } \\
\text { VALUE } \\
\left(\mathrm{nCi} / \mathrm{m}^{2}\right)\end{array}$ & $\begin{array}{c}\text { AVERAGE } \\
\text { VALUE } \\
\left(\mathrm{nCi} / \mathrm{m}^{2}\right)\end{array}$ & $\begin{array}{l}\text { MAX VALUE } \\
\text { FRACTION OF } \\
\text { DCG }\end{array}$ \\
\hline americium-241 & 5 & 96.00 & 44.16 & 64.28 & 0.04 \\
\hline barium-133 & 5 & 4.95 & 4.00 & 4.35 & 0.00 \\
\hline cobalt-60 & 5 & 2.69 & 0.50 & 1.20 & 0.00 \\
\hline cesium-137 & 5 & 235.68 & 164.50 & 190.53 & 0.07 \\
\hline europium-152 & 5 & 210.97 & 13.43 & 106.88 & 0.12 \\
\hline europium -154 & 5 & 13.05 & 8.69 & 11.35 & 0.01 \\
\hline europium -155 & 5 & 1.27 & 0.95 & 1.09 & 0.00 \\
\hline plutonium-238 & 5 & 142.52 & 65.55 & 95.43 & 0.02 \\
\hline plutonium -239 & 5 & 644.53 & 296.48 & 431.58 & 0.12 \\
\hline strontium-90 & 5 & 436.16 & 304.43 & 352.59 & 0.00 \\
\hline
\end{tabular}

The slightly elevated RIDP measurements were collected within the known contaminant plume of CASs 09-23-14 and 09-99-01. Therefore, these results support the process knowledge, Contaminated Land Report survey data, and fly-over data. This evaluation is not intended as a formal dose assessment because this area is contiguous to CASs 09-23-14 and 09-99-01, which will be addressed with a future CAU closure. 


\subsubsection{CONCLUSION}

CAS 09-23-06 consists of a mound of soil associated with the PITON-A test. PITON-A was an underground detonation with associated post-test drilling operations. The detonation cavity is part of the UGTA Sub-Project. The low levels of contamination present near the site are not attributable to the PITON-A detonation but are associated with the HOOD and CHARLESTON detonations, which will be addressed with a future CAU closure (Figure 7). There were no releases due to the post-test drilling, and elevated radiological readings recorded during the detonation itself are not indicative of a release to the surface soils. This is supported by process knowledge, 100-percent coverage fly-over survey data, focused measurements provided by the Contaminated Land Report survey data, and RIDP data. The demonstrated lack of radiological releases to the surface soils related to CAS 09-23-06 leads to the conclusion that there is no credible exposure pathway that could cause an NTS worker to receive a dose greater than $25 \mathrm{mrem} / \mathrm{yr}$ at this CAS.

This CAS requires no additional controls under the FFACO. While not required to achieve FFACO closure under the DQOs developed for CAU 107, the site is posted under 10 CFR 835 as a URMA, thereby further ensuring that an NTS worker will not receive a dose greater than $25 \mathrm{mrem} / \mathrm{yr}$. Based on the information presented above, data are adequate to support a closure option of no further action. 


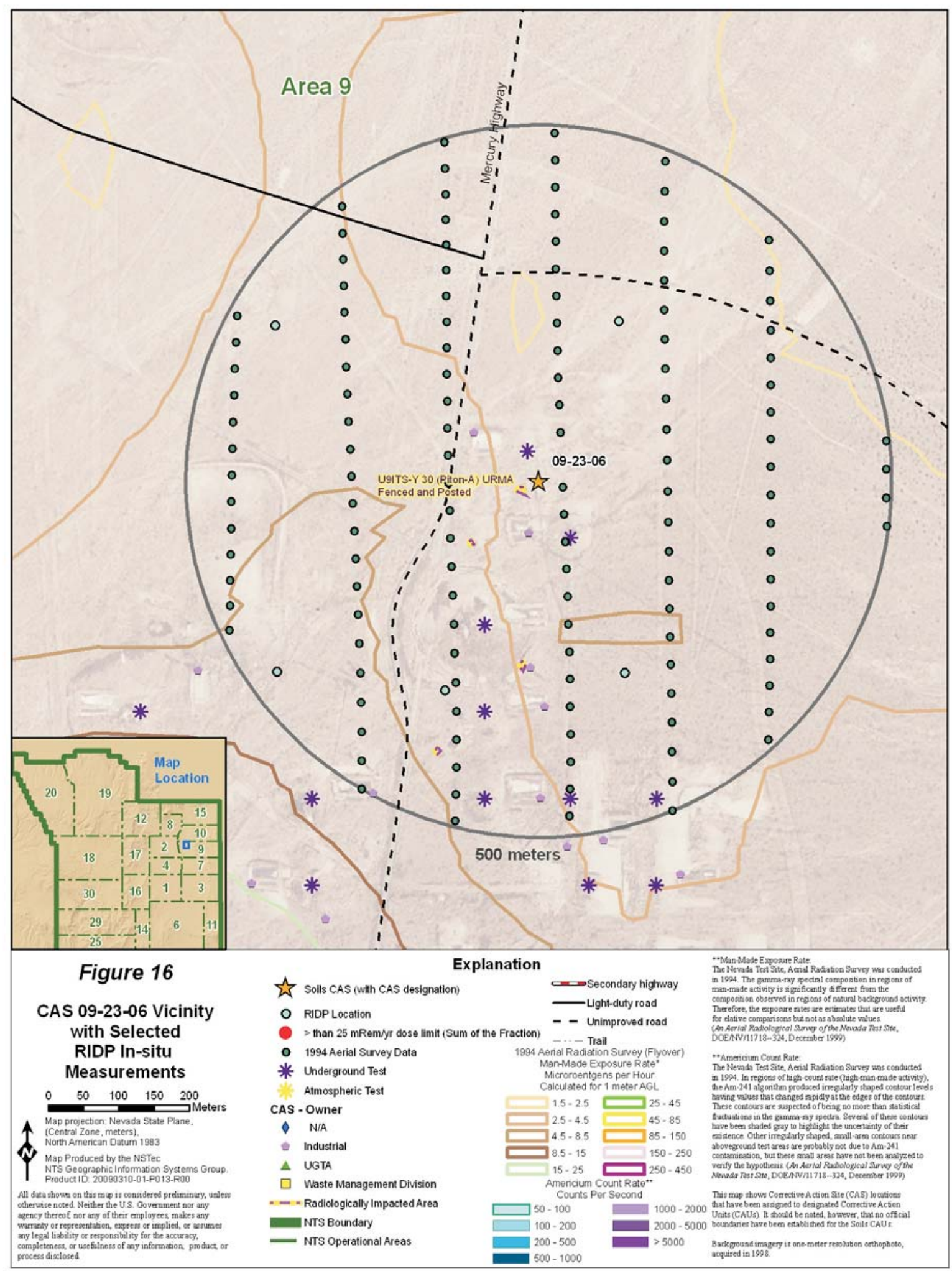

FIGURE 16 


\subsection{CAS 10-23-04, ATMOSPheric Test Site M-10}

CAS 10-23-04 was designated to address potential surface soil contamination associated with the JOHN atmospheric nuclear weapons test. This test was detonated at approximately 19,000 ft amsl (DNA, 1981). This test left no surface impression, and there is no distinct contamination plume associated with this CAS. Ground zero does not exist for this test given the height of detonation. Field visits were made to the site on February 1, 1996, and March 20, 2006. The 1996 site visit report recorded no fencing or postings present. Postings are not required at this CAS location under requirements of 10 CFR 835. Field crew and vehicles were surveyed upon completion of the field visit. No readings were detected above background levels. During the 2006 site visit, there were no postings or fencing other than the site marker placed during the 1996 field visit.

\subsubsection{OPERATIONAL History}

The JOHN test, conducted on July 19, 1957, was part of Operation Plumbbob. The test had a yield of about 2-kt and was a test of an air-to-air missile system (DOE/NV, 2000). The JOHN nuclear device was launched by a rocket and was detonated well above the ground surface, causing a wide, swift dispersion pathway. The radiological safety report for this test states, "The initial ground survey teams detected no increase in radiation levels within the Nevada Test Site" (REECo, 1957).

\subsubsection{RELEASE INFORMATION}

The JOHN test caused a radiological release to the air space above the NTS. However, process knowledge and operational history strongly indicate that the JOHN test did not cause radiological contamination of surface soils within the boundaries of the NTS. Surface radiological contamination produced by a nuclear test conducted close to ground surface is largely from materials being drawn into the resulting radioactive cloud (DNA, 1981). Since this test was detonated at 19,000 ft amsl, this process did not occur (Spriggs, 2007).

\subsubsection{HistoriCAl CHARACTERIZATION INFORMATION}

The surface location for ground zero of the JOHN test location is well within the SEDAN ROI and within the contaminant extent from the SEDAN test (CAS 10-45-01). Thus, the characterization data in this area are more representative of CAS 10-45-01, not CAS 10-23-04. This area will be addressed with a future CAU closure.

The JOHN test could not have caused either surface contamination or ground activation because the height of the burst was greater than 10,000 ft (Spriggs, 2007). This is supported by the data in Section 2.3 of this SAFER Plan showing that neither contamination nor ground activation occurred as a result of the HA test, which was also detonated well above ground level. Because this site is within the SEDAN contaminant plume, this CAS is evaluated through the historical operational information. Data collected in this area characterize the conditions related to CAS 10-45-01 and therefore are only discussed briefly below. 


\subsubsection{Fly-Over Data}

The 1994 fly-over survey shows low levels of detectable radioactivity (Hendricks and Riedhauser, 1999) near the SEDAN, UNCLE, and ESS tests, associated with CASs 10-45-01, 10-45-02, and 10-45-03. There were 140 measurements in a 500-m radius of surface ground zero of the JOHN test (Figure 17). While the fly-over data, depicted in Figure 17, are shown as points, the field of view is large; thus, the fly-over survey provided 100-percent coverage. These data were analyzed as described in Proctor (1997) and Hendricks and Riedhauser (1999). The results of the analysis are shown in Table 43. Twelve measurements for americium-241 were above the detection limit, and all measurements for total man-made radioactivity were greater than the detection limit. These measurements were in the known, contiguous contaminant plume of CASs 10-45-01, 10-45-02, and 10-45-03, which will be addressed with a future CAU closure.

\section{TABLE 43. CAS 10-23-04 Fly-OVER DATA SUMMARY}

\begin{tabular}{||l|c|c|c||}
\hline MEASUREMENT TYPE & $\begin{array}{c}\text { NUMBER OF } \\
\text { MEASUREMENTS }\end{array}$ & $\begin{array}{c}\text { APPROXIMATE } \\
\text { DETECTION LIMIT }\end{array}$ & $\begin{array}{c}\text { NUMBER } \\
\text { MEASUREMENTS } \\
\text { >DETECTION LIMIT }\end{array}$ \\
\hline Total man-made & 140 & $1.5 \mathrm{microR} / \mathrm{hr}$ & 140 \\
\hline americium-241 & 140 & $50 \mathrm{cps}$ & 12 \\
\hline
\end{tabular}

\subsubsection{Contaminated Land Report Data}

Radiological surveys conducted for BN (2000) did not include this CAS location because the area is not controlled for radiological purposes.

\subsubsection{3 $\quad$ RIDP Data}

RIDP measurements in the vicinity of the CAS characterize the extent of the plume from the SEDAN, UNCLE and ESS tests (McArthur and Kordas, 1985) (Figure 17). RIDP measurements within the vicinity of the surface ground zero of the JOHN test were evaluated against limits set forth in Anspaugh and Daniels (1995) as explained in Section 2.2.4.3 of this SAFER Plan. Table 44 provides the maximum, minimum, and average values and compares the maximum value to the limits set forth in Anspaugh and Daniels (1995). All values are well below these limits. This evaluation is not intended as a formal dose assessment because the area is contiguous to CASs 10-45-01, 10-45-02, and 10-45-03, which will be addressed with a future CAU closure.

TABLE 44. CAS 10-23-04 RIDP DATA SUMMARY

\begin{tabular}{|l|r|r|r|r|r||}
\hline RADIONUCLIDE & $\begin{array}{c}\text { Number OF } \\
\text { MEASUREMENTS }\end{array}$ & $\begin{array}{c}\text { MAXIMUM } \\
\text { VALUE } \\
\left(\mathrm{nCi} / \mathrm{m}^{2}\right)\end{array}$ & $\begin{array}{c}\text { MINIMUM } \\
\text { VALUE } \\
\left(\mathrm{nCi} / \mathrm{m}^{2}\right)\end{array}$ & $\begin{array}{c}\text { AVERAGE } \\
\text { VALUE } \\
\left(\mathrm{nCi} / \mathrm{m}^{2}\right)\end{array}$ & $\begin{array}{l}\text { MAX VALUE } \\
\text { FRACTION OF } \\
\text { DCG }\end{array}$ \\
\hline americium-241 & 4 & 325.94 & 169.83 & 249.83 & 0.13 \\
\hline cobalt-60 & 4 & 10.60 & 4.37 & 7.20 & 0.01 \\
\hline cesium-134 & 4 & 0.00 & 0.00 & 0.00 & 0.00 \\
\hline cesium-137 & 4 & 1320.03 & 757.31 & 1037.40 & 0.41 \\
\hline europium-152 & 4 & 25.09 & 19.83 & 21.63 & 0.01 \\
\hline europium-154 & 4 & 18.42 & 16.54 & 17.90 & 0.01 \\
\hline europium-155 & 4 & 4.24 & 1.80 & 2.48 & 0.00 \\
\hline lutetium-174 & 4 & 1.17 & 0.30 & 0.67 & 0.00 \\
\hline plutonium-238 & 4 & 277.11 & 144.40 & 212.40 & 0.05 \\
\hline plutonium-239 & 4 & 1866.97 & 972.78 & 1431.00 & 0.36 \\
\hline
\end{tabular}




\subsubsection{CONCLUSION}

The JOHN detonation occurred at approximately 19,000 ft amsl and did not cause surface radiological surface contamination at or near this CAS. The low levels of contamination present near the site are not attributable to the JOHN detonation but are associated with the SEDAN, ESS, and UNCLE detonations, which will be addressed with a future CAU closure (Figure 7). This is supported by process knowledge, 100-percent coverage fly-over survey data, and RIDP data. The demonstrated lack of radiological releases to the surface soils related to CAS 10-23-04 leads to the conclusion that there is no credible exposure pathway that could cause an NTS worker to receive a dose greater than $25 \mathrm{mrem} / \mathrm{yr}$ at this CAS.

This CAS requires no additional controls under the FFACO. Based on the information presented above, data are adequate to support a closure option of no further action. 
Date: March 2009

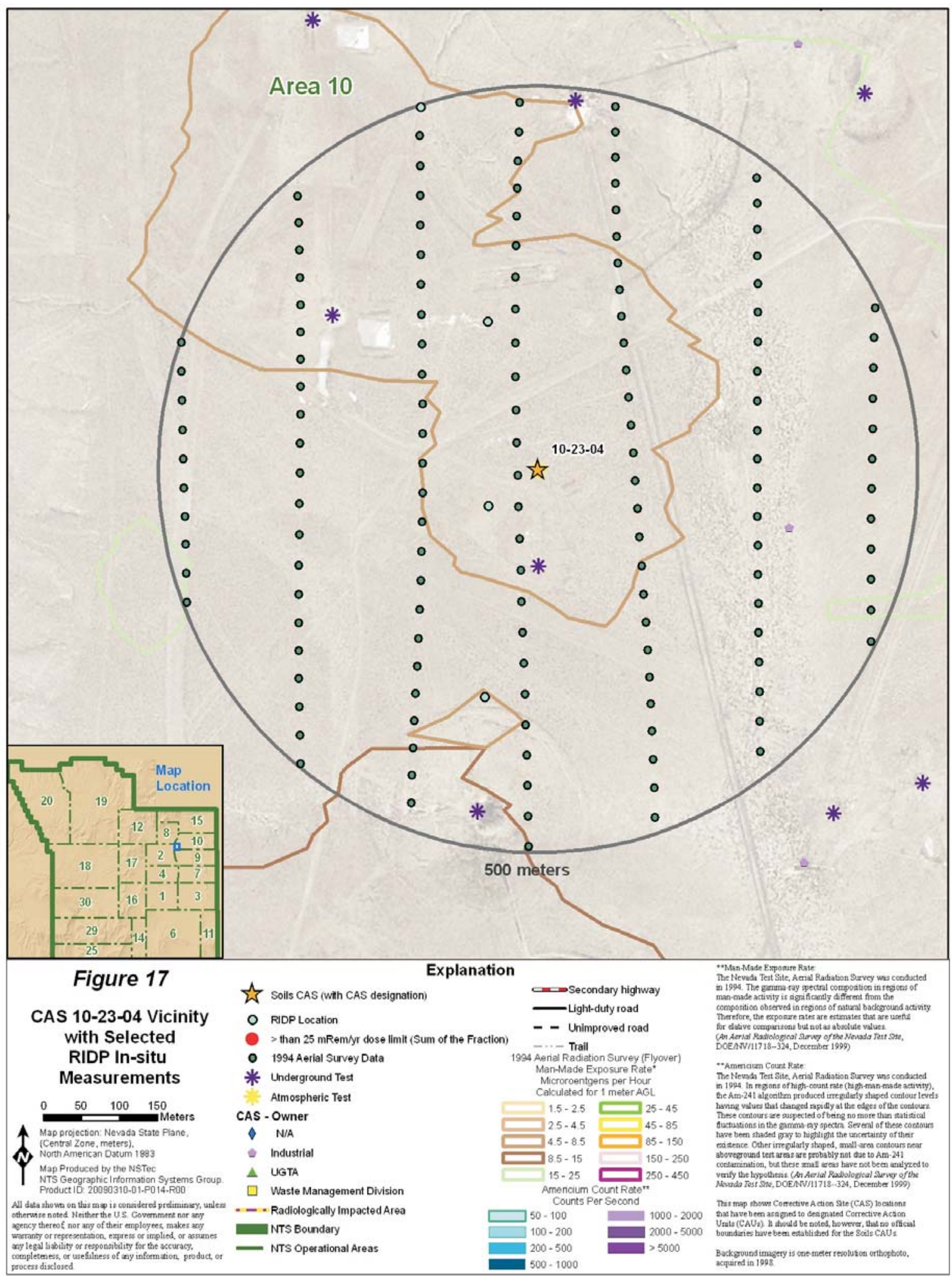

FIGURE 17 


\subsection{CAS 18-23-02, U-18D CRATER (SULKY)}

CAS 18-23-02 was designated to address potential surface soil contamination associated with the SULKY nuclear weapons test. The CAS is described in the FFACO as a fenced RMA of approximately $50,900 \mathrm{ft}^{2}$ with expected contaminants of transuranics and fission products. The SULKY test produced a circular mound approximately $79 \mathrm{ft}$ in radius and $21 \mathrm{ft}$ high consisting of rubble and large basalt blocks (Videon, 1965). The original mound volume was estimated at 11,379 cubic yards (Videon, 1965). This CAS includes only the surface expression of the SULKY rubble mound and ejecta inside the fenced RMA.

\subsubsection{OPERATIONAL HiSTORY}

The SULKY test was conducted during Operation Whetstone, and was part of the Plowshare Program. It was conducted on December 18, 1964, and had a 92-ton yield (DOE/NV, 2000). SULKY was detonated at a depth of $90 \mathrm{ft}$ in emplacement hole U-18d (Videon, 1965). The test was conducted on Buckboard Mesa in the western part of the NTS. The purposes of the test were to determine the distribution and concentrations of radioactivity released from this type of test and to obtain information on cratering mechanics in basalt (DOE/NV, 1997).

The SULKY device was placed in a 36-inch-diameter hole. The hole was then stemmed using a plug of "Cal Seal" (a fast-setting grout) directly above the device, and the remainder of the borehole was filled with pea gravel (Videon, 1965). Two 100-ft-deep angle holes and one 25-ft-deep hole were drilled adjacent to the U-18d emplacement hole for installation of instrumentation. The explosion resulted in a rubble mound referred to as a "retarc" ("crater" spelled backwards) with minimal ejecta and few particulates. Two years after the test, the U.S. Army Corps of Engineers Waterways Experiment Station drilled two holes adjacent to the rubble mound to obtain data on subsurface characteristics of the rubble.

\subsubsection{RELEASE INFORMATION}

Release of radionuclides was expected from the SULKY test. DOE/NV (1996) states that the release was detected off site and identifies several isotopes of krypton, strontium, ytterbium, iodine, xenon, cesium, and barium in the release. The report also lists the test release at $\mathrm{R}+12$ hours as $1.3 \times 10^{5}$ curies. The test release occurred from the surface ground zero location and lasted for 35 days.

\subsubsection{HiSTORICAL CHARACTERIZATION INFORMATION}

The following data were used to evaluate the potential surface release for CAS 18-23-02 and determine the likelihood of a release to surface soils resulting from SULKY.

\subsubsection{Fly-Over Data}

The fly-over survey performed in 1994 does not show detectable levels of radionuclides in the area of this CAS and does not identify any nearby areas as ROIs (Hendricks and Riedhauser, 1999). The fly-over survey process is well established and has been used at many sites to make the "yes-no" type of decision used in this SAFER Plan (NNSA/NSO, 2005). The fly-over data have been used in a semi-quantitative way to support the conclusion made based on operational history that a widespread release to surface soils did not occur as a result of the SULKY detonation or associated activities. There were 137 measurements collected within a 500-m 
radius of the SULKY detonation (Figure 18). While the fly-over data, depicted in Figure 18, are shown as points, the field of view of the detector is large; thus, the fly-over survey provided 100-percent coverage of this area. These data were analyzed as described in Proctor (1997) and Hendricks and Riedhauser (1999). The results of the analyzed survey data are shown in Table 45. All measurements were less than the detection limit of the instrumentation; however, these data only evaluate the potential for a widespread release and do not quantify the known, low-level point-source contamination at the site.

TABle 45. CAS 18-23-02 Fly-OVER DATA SumMary

\begin{tabular}{|l|c|c|c|}
\hline MEASUREMENT TYPE & $\begin{array}{c}\text { NUMBER OF } \\
\text { MEASUREMENTS }\end{array}$ & $\begin{array}{c}\text { APPROXIMATE } \\
\text { DETECTION LIMIT }\end{array}$ & $\begin{array}{c}\text { NUMBER } \\
\text { MEASUREMENTS } \\
\text { >DETECTION LIMIT }\end{array}$ \\
\hline Total man-made & 137 & $1.5 \mathrm{microR} / \mathrm{hr}$ & 0 \\
\hline americium-241 & 137 & $50 \mathrm{cps}$ & 0 \\
\hline
\end{tabular}

The fly-over data presented above represent many individual measurements (referred to as point data), and each measurement is corrected for background radiation. The fly-over survey process continuously collects background radiation levels then corrects each measurement to remove it, resulting in data that show the added man-made radiation from testing or other activities. The fly-over measurements for total man-made radiation are very sensitive, with the detection limit of $1.5 \mathrm{microR} / \mathrm{hr}$. Typical background exposure rates are approximately $15 \mathrm{microR} / \mathrm{hr}$. Thus, the detection limit of $1.5 \mathrm{microR} / \mathrm{hr}$ results in detection of man-made radiation that is greater than approximately 10 percent of natural background radiation.

The fly-over surveys are very sensitive to americium-241. Americium-241 sensitivity is approximately $50 \mathrm{cps}$. A specific correlation to soil concentration values was not performed; however, a conservative correlation of $50 \mathrm{cps}$ to $300 \mathrm{nCi} / \mathrm{m}^{2}$ has been estimated by RSL based on other similar flights and the flight altitude of $200 \mathrm{ft}$. This value, $300 \mathrm{nCi} / \mathrm{m}^{2}$, was then compared to RIDP measurements made in non-operational areas of the NTS where no local releases of radioactive material occurred to determine whether the fly-over survey is capable of discerning levels of radioactivity indicative of a widespread radiological release. Since the RIDP values in the non-operational areas range from 24 to $573 \mathrm{nCi} / \mathrm{m}^{2}$ and the fly-over sensitivity is approximately $300 \mathrm{nCi} / \mathrm{m}^{2}$, this shows that the fly-over survey is capable of discerning where operational releases have occurred. No americium-241 fly-over survey measurements were greater than the detection limit, similar to the non-operational areas of the NTS. These data confirm that there was not a widespread release to surface soils.

\subsubsection{Contaminated Land Report Data}

BN (2000) provides radiological survey results for this area. Measurements collected include exposure rates and FIDLER readings. Removable alpha and beta/gamma contamination were also assessed. Measurements were taken along the fence line and on some boulders within the RMA. All measurements were consistent with background levels except for one FIDLER measurement collected inside the RMA on a boulder. The survey results show that contamination is not migrating outside the RMA. Table 46 presents the results of these surveys (BN, 2000). 
TABLe 46. CAS 18-23-02 CONTAMinated LAND SuRVey DATA Summary

\begin{tabular}{|c|c|c|c|c|c|}
\hline $\begin{array}{l}\text { MEASUREMENT } \\
\text { TYPE }\end{array}$ & $\begin{array}{c}\text { NUMBER OF } \\
\text { MEASUREMENTS }\end{array}$ & $\begin{array}{l}\text { MAXIMUM } \\
\text { VALUE }\end{array}$ & $\begin{array}{l}\text { MINIMUM } \\
\text { VALUE }\end{array}$ & $\begin{array}{l}\text { AVERAGE } \\
\text { VALUE }\end{array}$ & $\begin{array}{l}\text { APPROXIMATE } \\
\text { INSTRUMENT } \\
\text { SENSITIVITY } \\
\end{array}$ \\
\hline Removable Alpha & 15 & $2 \mathrm{dpm} / 100 \mathrm{~cm}^{2}$ & $0 \mathrm{dpm} / 100 \mathrm{~cm}^{2}$ & $0.27 \mathrm{dpm} / 100 \mathrm{~cm}^{2}$ & $5 \mathrm{dpm} / 100 \mathrm{~cm}^{2}$ \\
\hline Removable Beta & 15 & $10 \mathrm{dpm} / 100 \mathrm{~cm}^{2}$ & $0 \mathrm{dpm} / 100 \mathrm{~cm}^{2}$ & $2.6 \mathrm{dpm} / 100 \mathrm{~cm}^{2}$ & $16 \mathrm{dpm} / 100 \mathrm{~cm}^{2}$ \\
\hline Exposure Rate & 15 & $30 \mathrm{uR} / \mathrm{hr}$ & $15 \mathrm{uR} / \mathrm{hr}$ & $16 \mathrm{uR} / \mathrm{hr}$ & $20 \mathrm{uR} / \mathrm{hr}^{1}$ \\
\hline FIDLER & 15 & $140 \mathrm{cps}$ & $53 \mathrm{cps}$ & $65 \mathrm{cps}$ & $100 \mathrm{cps}$ \\
\hline
\end{tabular}

${ }^{1}$ Approximate Instrument Sensitivity is estimated based on typical background values and instrument performance. All values reported below the instrument sensitivity are estimates only.

These ground-based survey data consist of measurements that are focused in the area of the CAS, thereby augmenting the wide-area data collected via fly-over surveys indicating that a widespread contaminant release did not occur and that the known historical contamination has not migrated outside of the RMA.

The NV/YMP RadCon Manual (NNSA/NSO, 2004b) is used at the NTS to implement the requirements set forth in 10 CFR 835 . The manual allows for the release of areas from radiological controls when certain radiological limits are met. The limits were established as acceptable levels for use by the general public and, thus, are conservative given the ongoing controls at CAS 18-23-02 and the lack of both public and worker access to the site. Table 47 outlines these release values. BN (2000) survey measurements in the area of CAS 18-23-02 are well below the radiological control limits outlined in Table 47.

\subsubsection{3 $\underline{\text { RIDP Data }}$}

The RIDP did not include the area of this CAS because radiological contamination was not suspected in this area (DRI, 2007). No RIDP measurements were used to evaluate this CAS. 
TABLe 47. Surface CONTAMination RELEASE VALUES ${ }^{1}$ IN DPM/100 CM$^{2}$

\begin{tabular}{||l|l|l||}
\hline \multicolumn{1}{|c|}{ RADIONUCLIDE } & \multicolumn{1}{|c||}{ REMOVABLE $^{2,4}$} & $\begin{array}{c}\text { TOTAL (FIXED } \\
\text { +REMOVABLE) }\end{array}$ \\
\hline $\begin{array}{l}\text { natural uranium, uranium-235, uranium-238, and associated decay } \\
\text { products }\end{array}$ & $1,000^{7}$ & $5,000^{7}$ \\
\hline $\begin{array}{l}\text { transuranics, radium-226, radium-228, thorium-230, thorium-228, } \\
\text { protactinium-231, actinium-227, iodine-125, and iodine-129 }\end{array}$ & 20 & 500 \\
\hline $\begin{array}{l}\text { natural thorium, thorium-232, strontium-90, radium-223, radium- } \\
\text { 224, uranium-232, iodine-126, iodine-131, and iodine-133 }\end{array}$ & 200 & 1,000 \\
\hline $\begin{array}{l}\text { beta-gamma emitters (nuclides with decay modes other than alpha } \\
\text { emission or spontaneous fission), except strontium-90 and others } \\
\text { noted above }\end{array}$ & 1,000 & 5,000 \\
\hline tritium and tritiated compounds $^{6}$ & 10,000 & N/A \\
\hline
\end{tabular}

1 The values in this table, with the exception noted in footnote 5 , apply to radioactive contamination deposited on, but not incorporated into the interior or matrix of, the contaminated item. Where surface contamination by both alpha- and beta-gamma-emitting nuclides exists, the limits established for alpha- and beta-gamma-emitting nuclides apply independently.

2 As used in this table, dpm (disintegrations per minute) means the rate of emission by radioactive material as determined by correcting the counts per minute observed by an appropriate detector for background, efficiency, and geometric factors associated with the instrumentation.

3 The levels may be averaged over 1 square meter provided the maximum surface activity in any area of $100 \mathrm{~cm}^{2}$ is less than three times the value specified. For purposes of averaging, any square meter of surface shall be considered to be above the surface contamination value if: (1) From measurements of a representative number of sections it is determined that the average contamination level exceeds the applicable value; or (2) it is determined that the sum of the activity of all isolated spots or particles in any $100 \mathrm{~cm}^{2}$ area exceeds three times the applicable value.

4 The amount of removable radioactive material per $100 \mathrm{~cm}^{2}$ of surface area should be determined by swiping the area with dry filter or soft absorbent paper, applying moderate pressure, and then assessing the amount of radioactive material on the swipe with an appropriate instrument of known efficiency. (Note: The use of dry material may not be appropriate for tritium.) When removable contamination on objects of surface area less than $100 \mathrm{~cm}^{2}$ is determined, the activity per unit area shall be based on the actual area and the entire surface shall be wiped. It is not necessary to use swiping techniques to measure removable contamination levels if direct scan surveys indicate that the total residual surface contamination levels are within the limits for removable contamination.

5 This category of radionuclides includes mixed fission products, including the strontium- 90 present in them. It does not apply to strontium-90 which has been separated from the other fission products or mixtures where the strontium-90 has been enriched.

6 Tritium contamination may diffuse into the volume or matrix of materials. Evaluation of surface contamination shall consider the extent to which such contamination may migrate to the surface in order to ensure the surface contamination value provided in this appendix is not exceeded. Once this contamination migrates to the surface, it may be removable, not fixed; therefore, a "Total" value does not apply.

\subsubsection{CONCLUSION}

SULKY was an underground detonation that resulted in a rubble mound, or "retarc." Data presented above show that no widespread release to surface soils that could cause an NTS worker dose greater than $25 \mathrm{mrem} / \mathrm{yr}$ occurred; therefore, data are adequate to support a closure option of closure in place with administrative controls. Historical evidence indicates that there may be limited contamination within the RMA; however, representative sampling of this site would be difficult to achieve due to the nature of the large rubble pile created by the test and the difficulty in reaching the areas that would most likely be contaminated. Furthermore, any contamination is likely on the large rubble, not in the soils.

The site is currently posted in compliance with 10 CFR 835 as an RMA. Contamination levels along this boundary are below the levels specified in Table 47, and contamination is not migrating outside the RMA (BN, 2000). A UR will be implemented that encompasses the RMA including the "retarc" area. The UR is an adequate administrative control to limit site access and worker dose. 


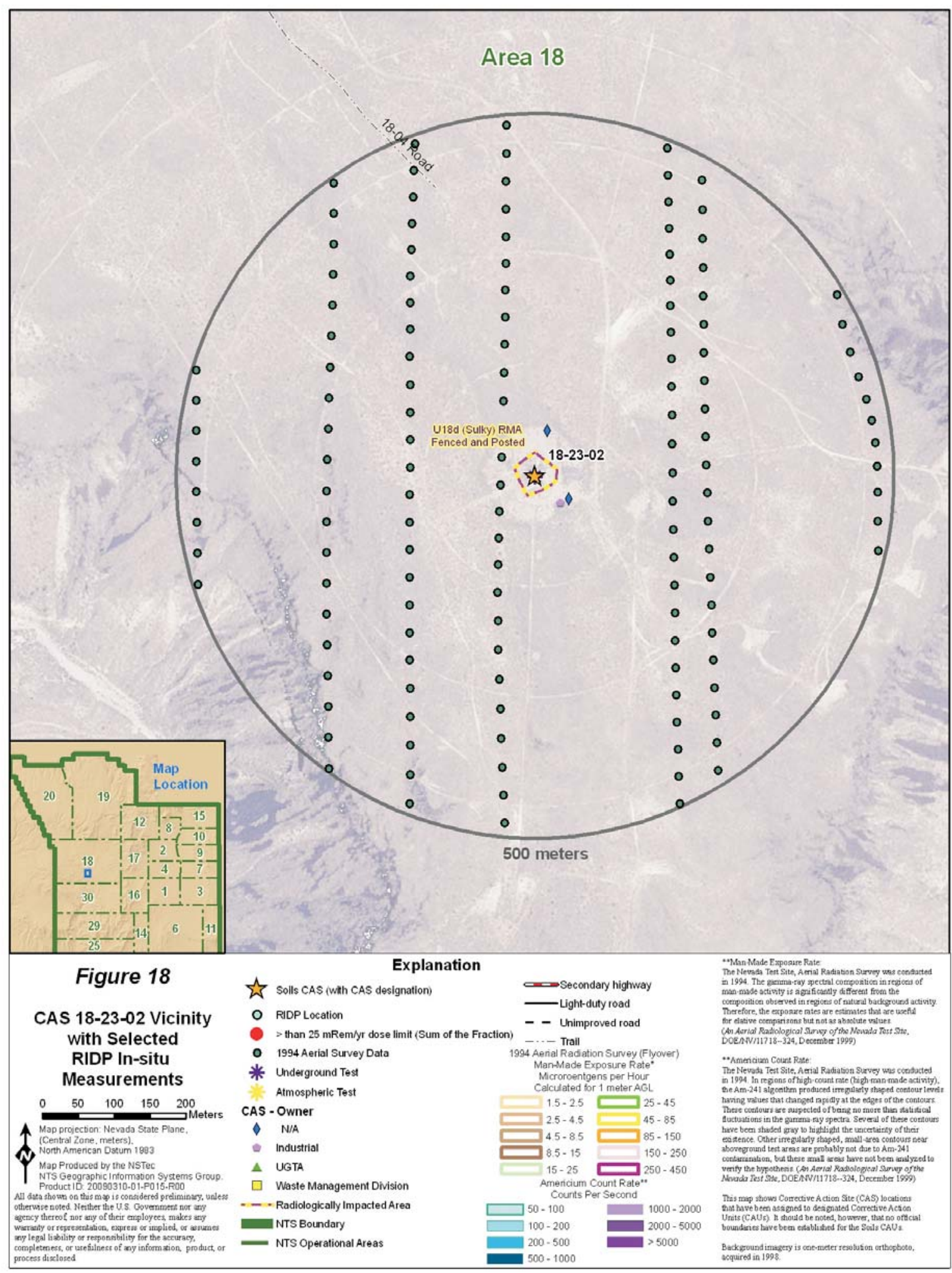

\section{FIGURE 18}


CAU 107 SAFER Plan

Section: Unit Description

Revision: 1

Date: March 2009

\section{THIS PAGE INTENTIONALLY LEFT BLANK}




\subsection{DATA QUALITY OBJECTIVES}

The DQO process is a seven-step systematic planning method based on the scientific method. The information presented in this document is based on historical data generated from preliminary assessment activities for CAU 107. The DQOs were developed according to the EPA Guidance on Systematic Planning Using the Data Quality Objectives Process (EPA, 2006). The steps systematically build on the data acquired during preliminary assessment work and background research.

\subsection{SUMMARY OF DQO ANALYSIS}

\subsubsection{State The Problem (SteP 1)}

Step 1 of the DQO process describes the problem to be studied and develops a CSM to gain a sufficient understanding in defining the problem.

\subsubsection{Problem Statement}

The problem statement for CAU 107 is "Conceptual corrective actions have been clearly identified based on historical data and background information. Are the sites sufficiently characterized to support closure through no further action and/or administrative controls?"

\subsubsection{Conceptual Site Model}

The CSM is used to organize and communicate information about site characteristics. It reflects the best interpretation of available information. The CSM is based on historical documentation, personnel interviews, site process knowledge, site visits, photographs, engineering drawings, field screening, and analytical results. The CSM describes the most probable scenario for current conditions at the site and defines the assumptions that are the basis for choosing a conceptual corrective action alternative.

The sites fall into the following categories:

- Category A: Sites associated with atmospheric tests with no confirmed release to surface soils

○ CAS 01-23-02, Atmospheric Test Site - High Alt

○ CAS 05-23-06, Atmospheric Test Site

○ CAS 10-23-04, Atmospheric Test Site M-10

- Category B: Sites associated with underground tests and detonations with no confirmed release to surface soils

○ CAS 02-23-02, Contaminated Areas (2)

- CAS 02-23-10, Gourd-Amber Contamination Area

- CAS 02-23-11, Sappho Contamination Area

- CAS 02-23-12, Scuttle Contamination Area

- CAS 03-23-24, Seaweed B Contamination Area

- CAS 03-23-28, Manzanas Contamination Area

○ CAS 09-23-06, Mound of Contaminated Soil 
- Category C: Sites associated with atmospheric or underground tests and detonations with possible release to surface soils

- CAS 02-23-03, Contaminated Berm

- CAS 03-23-27, Adze Contamination Area

- CAS 03-23-29, Truchas-Chamisal Contamination Area

○ CAS 04-23-02, Atmospheric Test Site T4-a

○ CAS 18-23-02, U-18d Crater (Sulky)

\subsubsection{IDENTIFY THE GOAL OF THE STUDY (STEP 2)}

Step 2 of the DQO process identifies the questions the study will attempt to resolve and what actions may result. The goal of the study is to answer the following questions satisfactorily:

1. Does historical information indicate that a release to ground surface soils occurred as a result of the associated detonation?

2. If so, is the soil impacted with contamination levels that exceed action levels?

3. If so, do the risks to personnel and the environment justify a corrective action, or are the current 10 CFR 835, "Occupational Radiation Protection," compliant controls adequate for this purpose?

\subsubsection{IDENTIFY INFORMATION INPUTS (STEP 3)}

Step 3 of the DQO process identifies the information needed to address the goals of the study.

\subsubsection{Information Needs}

In order to determine if a distinct, measurable release to the surface soils resulting from historical operations occurred and, if so, to quantify that release, existing historical information must be evaluated using the following criteria:

- Documented process knowledge indicates a release to surface soils has not occurred.

- Tests were documented to be performed well above ground surface.

○ Documented releases were short-lived, gaseous radionuclides.

- Location and direction of plume deposition paths (or lack thereof) were recorded in post-test documentation.

- Process knowledge and multiple, semi-quantitative data sets are in agreement with each other.

- Aerial survey data provide 100-percent coverage of areas.

- RIDP data were collected from areas most likely to be contaminated on a statistically based grid.

- Contaminated Lands Report Survey data were collected from areas most likely to be contaminated.

- Soil sampling data were collected under an approved CAIP from sites with similar CSMs.

\subsubsection{Sources of Information}

Existing information, such as historical documentation, personnel interviews, site process knowledge, site visits, photographs, and previous field screening and analytical results, will be evaluated to determine if it satisfies the decisions. 


\section{Qualitative Data}

Qualitative data identify or describe the characteristics or components of the site. The quality assurance (QA)/quality control (QC) requirements are the least rigorous for qualitative data. This measurement of quality is typically assigned to historical information and data where QA/QC may be highly variable or not known. Professional judgment is often used to generate qualitative data. Visual observations made during field visits, process knowledge about the sites and the nature of the atmospheric tests, and historical records and interviews will be used to confirm the absence or presence of contamination.

\section{Semi-quantitative Data}

Semi-quantitative data indirectly measure the quantity or amount of a characteristic or component. Inferences are drawn about the quantity or amount of a characteristic or component because a correlation has been shown to exist between the indirect measurement and a quantitative measurement. QA/QC requirements on semi-quantitative collection and measurements are high but may not be as rigorous as for quantitative data. Previous data that have been collected, including 1994 aerial radiological survey results (Hendricks and Riedhauser, 1999), RIDP data (McArthur, 1991), dose rate measurements, FIDLER readings, removable alpha and beta/gamma measurements, walkover radiological survey results, and other data, will be evaluated. Some portions of these data sets may be considered quantitative.

\section{Quantitative Data}

Quantitative data measure the quantity or amount of a characteristic or component. These data require the highest level of QA/QC in collection and measurement systems because the intended use of the data is to resolve primary decisions and/or to verify that closure standards have been met. Laboratory analytical data are generally considered quantitative. For the sites where analytical data have been collected, these data will be evaluated to verify they meet the information needs and satisfy the criteria for the decision inputs. Portions of the RIDP data may qualify as quantitative. Soil sampling data were collected and analyzed under both a field and laboratory QA/QC program. In situ measurements that directly quantify gamma-emitting radionuclides should be considered quantitative if appropriately validated.

\subsubsection{Define The Boundaries OF THE STUdy (STEP 4)}

Step 4 of the DQO process defines target populations of interest, specifies spatial boundaries and time constraints, and determines practical constraints on data collection.

\subsubsection{Population of Interest}

The population of interest to resolve the decisions includes the spatial boundaries of the sites. The spatial boundaries of all sites are limited to the surface or near-surface radioactive contamination. This CAU contains several types of sites:

- Atmospheric tests with no distinct, operationally related contaminant plume (3 of 15 sites)

- Underground detonations with no documented history of release of particulate radionuclides or documented releases were very low ( 7 of 15 sites)

- Atmospheric or underground tests and detonations with possible release to surface soils (5 of 15 sites, including CAS 02-23-03, CAS 03-23-27, and CAS 03-23-29, which involved pulling a contaminated cable from a test hole; CAS 04-23-02, an atmospheric test; and CAS 18-23-02, a cratering test) 


\subsubsection{Time Constraints}

The study data will be evaluated considering the length of time that will be required to complete the closure process and the closure report, as allowed for by the SAFER process. Time constraints that may affect the schedule of this project include approval of the SAFER Plan and DQOs. In addition, if classified information must be accessed, additional time may be needed to complete the study.

\subsubsection{DeVelop the Analytic ApProach (STEP 5)}

Step 5 of the DQO process develops a decision rule statement ("If..., then...") that defines the conditions under which possible alternative actions will be chosen. In this step, the action levels are specified and the sensitivity of the historical analytical methods is evaluated.

\subsubsection{Decision Rules}

The decision rules are as follows:

- If it is determined, through evaluation of the information inputs, that there has not been a distinct, measurable release to the surface soils resulting from the associated historical operations, then no further action will be required.

- If it is determined that a distinct, measurable release to the surface soils resulted from the associated historical operations, then soil contamination levels will be determined and compared to action levels. This will be accomplished by evaluating the following:

○ RIDP data, both in situ and soil sample values

- Aerial survey data where correlated

- Soil sampling data from like sites

- Soil sampling data collected in the vicinity of the site supporting other investigations

- If radiological concentrations in the soil are less than the action levels, then no further action will be required.

- If radiological concentrations are greater than action levels, then the risks to personnel and the environment will be evaluated to determine a path forward.

- If it is determined that clean closure is not feasible, the site(s) will be closed in place with administrative controls.

The decision flowchart is summarized in Figure 19.

\subsubsection{2 $\quad \underline{\text { Action Levels }}$}

The action levels for radiological contaminants are based on the National Council on Radiation Protection (NCRP)-recommended screening limits for construction, commercial, industrial land-use scenarios (NCRP, 1999) scaled to $25 \mathrm{mrem} / \mathrm{yr}$ dose constraint (Murphy, 2004) and 10 CFR 835, which provides guidelines for levels of radiological control depending on the levels of radiological hazards present (CFR, 1993). Remaining radiological contamination will be posted per the NV/YMP RadCon Manual (NNSA/NSO, 2004b). The action levels will be the greater of either the levels described above or the local area background levels. 


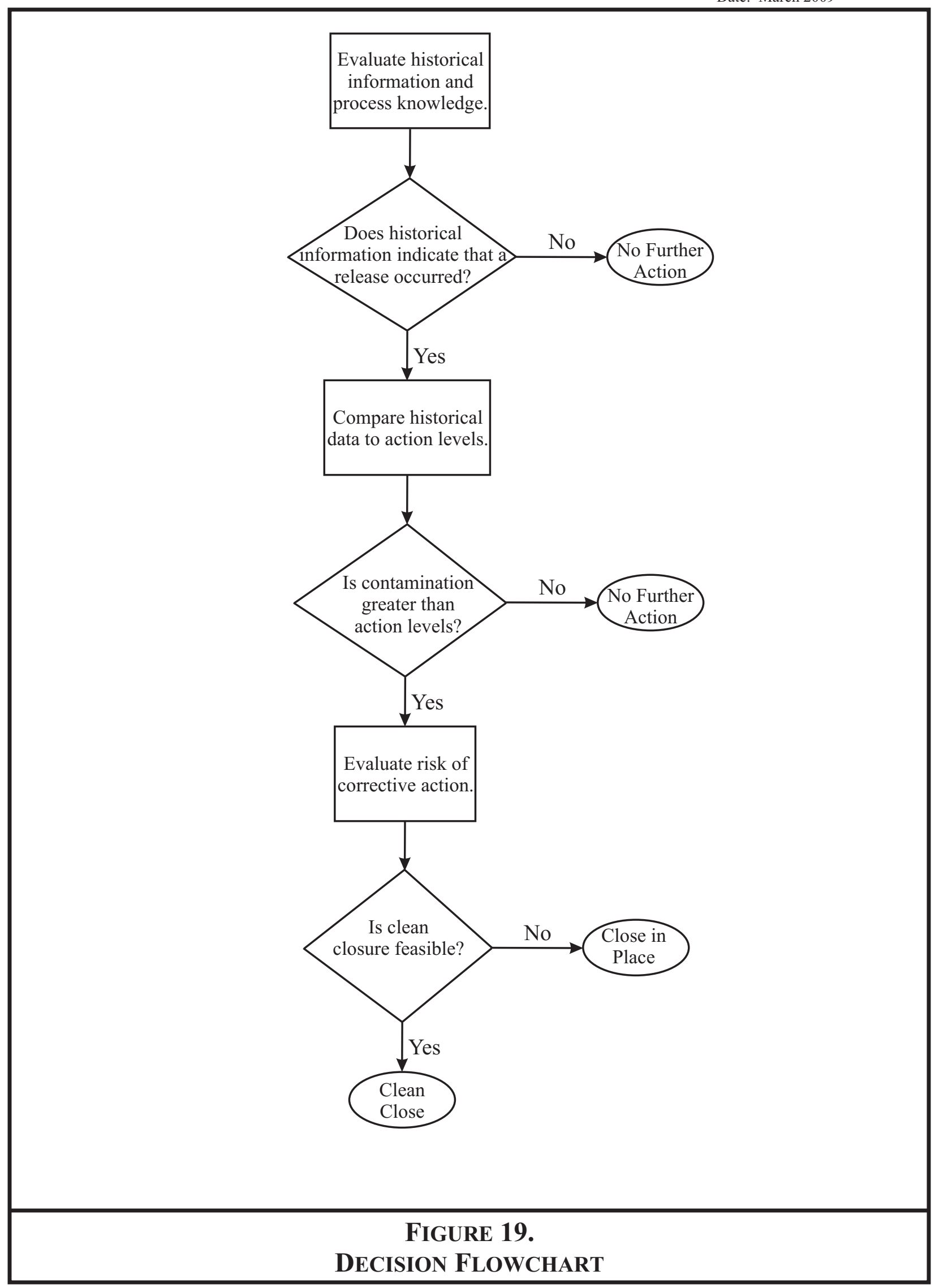




\subsubsection{Measurement and Analysis Sensitivity}

The historical measurement and analysis methods must be capable of measuring analyte concentrations at or below the corresponding action levels.

RIDP and aerial survey data allow calculations of minimum detectable activity. As appropriate, detection limits will be determined and compared to the action levels described above. Should detection limits be higher than the action levels, the detection limit will be used to make the appropriate closure decision, likely closure in place with administrative controls.

\subsubsection{Specify Performance Or ACCePtance Criteria (STep 6)}

Step 6 of the DQO process specifies performance criteria for the decision rules. Setting tolerable limits on decision errors requires the planning team to weigh the relative effects of threats to human health and the environment, expenditure of resources, and the consequences of an incorrect decision. This section provides an assessment of the possible outcomes of DQO decisions and the impact of those outcomes if the decisions are in error.

In general, confidence in DQO decisions will be established qualitatively by the following:

○ Developing CSMs

- Testing the validity of the CSMs based on an analysis of historical data

- Evaluating the quality of the data based on data quality indicator parameters

\subsubsection{Decision Errors}

The baseline condition (i.e., null hypothesis) is that soil has not been impacted with radionuclides at concentrations above action levels. The alternative condition is that the soil has been impacted with radionuclides at concentrations above action levels.

\section{False Rejection}

This error would mean deciding that the baseline condition is false when, in fact, it is true. This error means deciding that the soil is contaminated above action levels when it is not. The consequence of this decision is increased cost for the closure effort or post-closure requirements.

Several false positive errors have been identified through review of historical data. False positive errors include the determination that a release to the surface soils occurred as a result of a nuclear detonation when, in light of further historical investigation, it is demonstrated that such a release did not occur. Examples include CAS 01-23-02, where detonation occurred at 40,000 ft above ground, and CAS 03-23-24, where the only documented release involves very short-lived gaseous radionuclides.

\section{False Acceptance}

This error would mean deciding that the baseline condition is true when, in fact, it is false. This error means deciding that the soil is not contaminated when, in fact, it is contaminated above action levels. The potential consequence is an increased risk to human health and the environment. This error will be controlled by having a high degree of confidence that the data identify contamination, if present. To satisfy this criterion, the data will be closely evaluated to ensure that the data cover the areas of the sites and are adequate to detect contamination at or below the action levels. Further, since most of these sites are currently controlled for radiological purposes and there is no proximal public receptor, the impact of this error is minimized. 


\subsubsection{Develop the Plan for Obtaining Data (Step 7)}

Step 7 of the DQO process provides the general approach for resolving the decisions. The pool of existing data will be used to resolve the decisions outlined above.

\subsubsection{Process Knowledge}

The historical operations associated with these sites are well documented through multiple historical sources. Much of the operational information is based on semi-quantitative, or in some cases, quantitative data.

\subsubsection{Aerial Survey Data}

Detection limits for this data can be established. Aerial survey data provide 100-percent coverage of the study areas.

\subsubsection{Contaminated Lands Survey Data}

These data are semi-quantitative and have been found to be consistent with process knowledge, aerial survey data, and RIDP data where available.

\subsubsection{RIDP Data}

In general, RIDP did not cover these sites, as they were not suspected to contain surface contamination. In some cases, the RIDP study boundary for other soils sites extends into regions near the subject sites. If needed, RIDP data will be converted to units of picocuries per gram and compared to action levels. In general, evaluation of RIDP data will be used to support process knowledge assumptions and results of aerial surveys. RIDP survey areas were first determined through the use of aerial survey data. Aerial survey data provided a mechanism to bias study areas. Within each study area, survey and sampling points were determined through a statistical approach that generally provided higher measurement frequencies in areas of higher contamination and lower frequencies in areas of lower contamination.

Taken together, these data sets provide adequate information to do the following:

- Determine if there has been a distinct, measurable release to the surface soils resulting from the associated historical operations.

- Make comparisons to action levels as appropriate.

- Determine if appropriate controls are already in place, thus providing the basis for no further action.

- Identify cases in which appropriate controls are not in place, leading to closure in place with administrative controls. 


\subsection{RESUlts OF THE DQO ANALYSIS}

Results of the DQO analysis are presented in Section 2.0. The problem statement, "Conceptual corrective actions have been clearly identified based on historical data and background information. Are the sites sufficiently characterized to support closure through no further action and/or administrative controls?" has been resolved through the collection and evaluation of the items discussed in Section 3.1.3.1, Information Needs. The sites are sufficiently characterized to support the closure decisions described in this SAFER Plan. The evaluation found that there was sufficient process knowledge and historical characterization data to resolve the first goal of the study outlined in Section 3.1.2, Identify the Goal of the Study (Step 2). The resolution to the question, "Does historical information indicate that a release to ground surface soils occurred as a result of the associated test?" is presented in Section 2.0. Available historical documentation and characterization data indicate that a release to surface soils did not occur as a result of the associated tests. The decision rule outlined in Section 3.1.5.1, Decision Rules, states, "If it is determined, through evaluation of the information inputs, that there has not been a distinct, measurable release to the surface soils resulting from the associated historical operations, then no further action will be required." The sites will be closed as outlined in the SAFER Plan through the existing 10 CFR 835 controls. Table 48 provides a summary of the results of the evaluation for the CASs discussed in Section 2.0.

\subsubsection{ACTION LEVEL DETERMINATION AND BASIS}

Based on the evaluation presented in Section 2.0, releases of radionuclides to the surface soils as a result of the tests did not occur. The decision flowchart (Figure 19) indicates that the development of action levels is not required if a release to the surface soils did not occur.

\subsubsection{HYPOTHESIS TEST}

The null hypothesis is that a distinct, measurable release of radionuclides to the soils has not occurred as a result of the associated tests. The two types of decision errors are false rejection and false acceptance. A false rejection decision error would occur if it is determined that the soil is contaminated above action levels when it is not. The consequence of this decision is increased cost for the closure effort or post-closure requirements. A false acceptance decision error would occur if it is determined that the soil is not contaminated when, in fact, it is contaminated above action levels. The potential consequence is an increased risk to human health and the environment.

\subsubsection{Statistical Model}

A statistical model does not apply to closure of CAU 107.

\subsubsection{DESIGN DESCRIPTION/OPTION}

Because historical data have been used to determine a closure path for the sites in CAU 107 and additional data will not be collected, a design option for sampling is not applicable. 

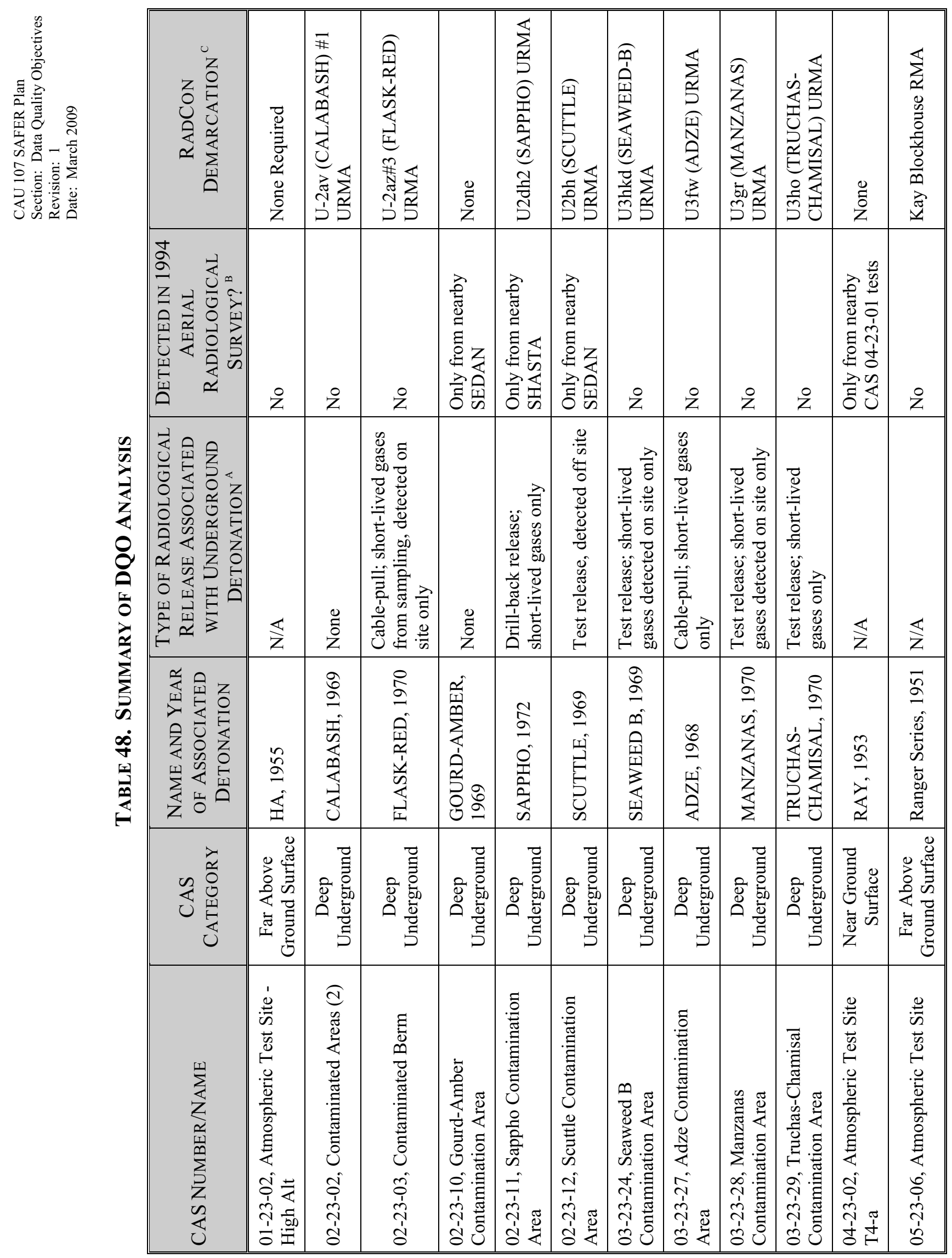


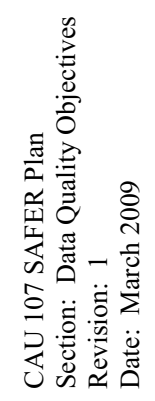

\begin{tabular}{|c|c|c|c|}
\hline 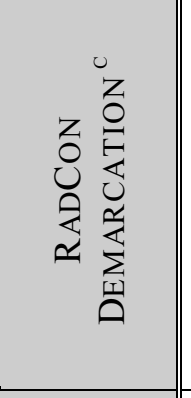 & 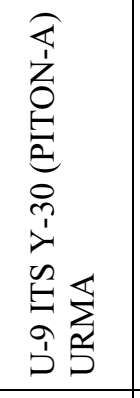 & $\begin{array}{l}\stackrel{0}{0} \\
\text { ż }\end{array}$ & 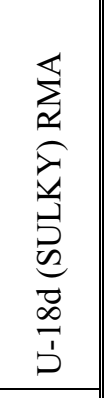 \\
\hline 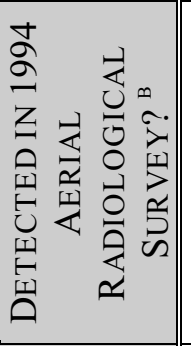 & 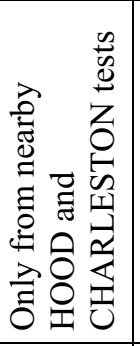 & 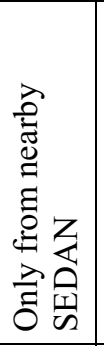 & \\
\hline 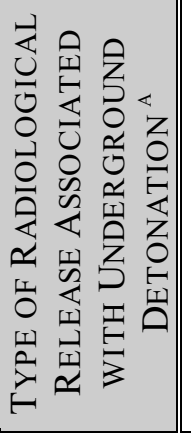 & 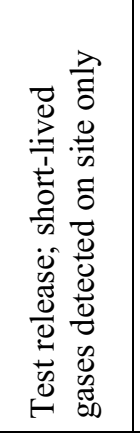 & $\overleftrightarrow{\mathrm{Z}}$ & $\begin{array}{l}\frac{0}{0} \\
\frac{0}{0} \\
0 \\
0 \\
0 \\
0 \\
0 \\
0 \\
0 \\
0 \\
0 \\
0\end{array}$ \\
\hline 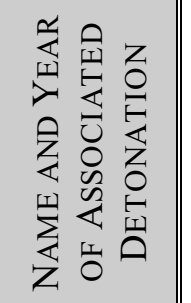 & 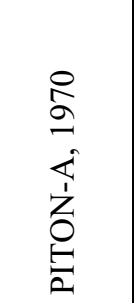 & $\begin{array}{l}\hat{n} \\
\stackrel{2}{z} \\
\text { 竞 } \\
\underline{n}\end{array}$ & $\frac{0}{2}$ \\
\hline 离 & 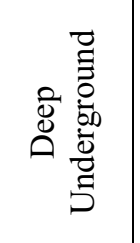 & 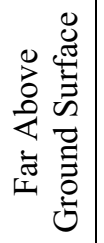 & Фे \\
\hline 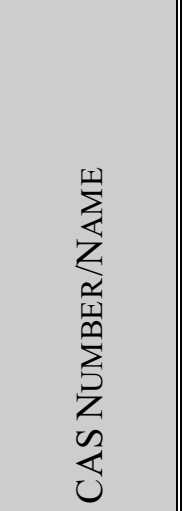 & 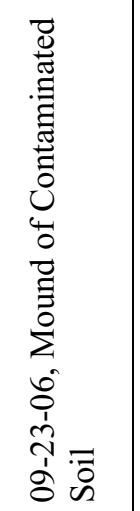 & 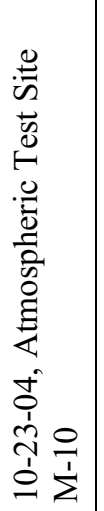 & 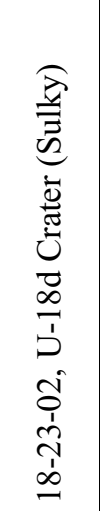 \\
\hline
\end{tabular}

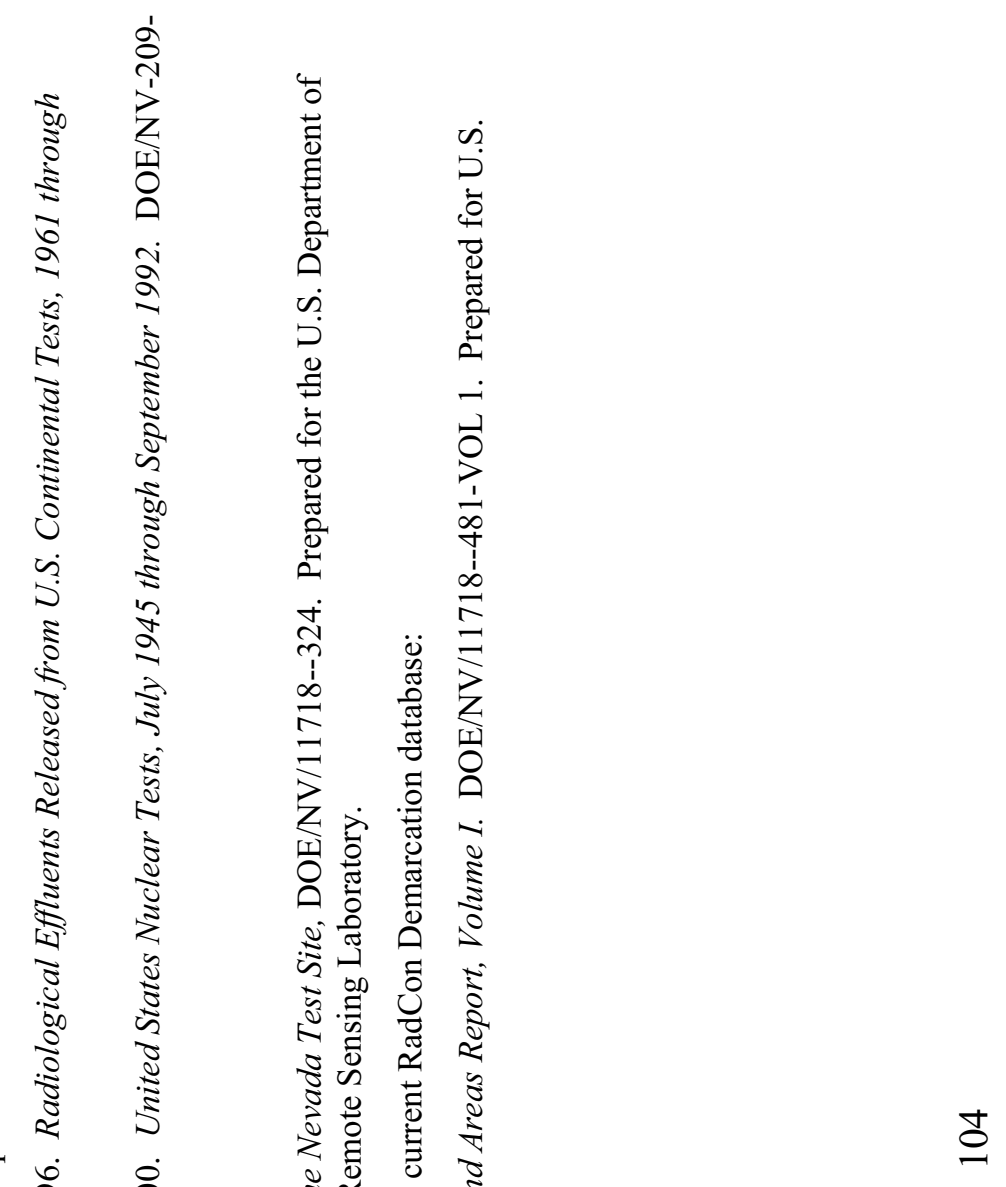




\subsubsection{CONCEPTUal Site Model}

Through the review of the process knowledge and historical data presented in Section 2.0, the CSM for 13 of the $15 \mathrm{CASs}$ is that a distinct, measurable release of radionuclides to the soils has not occurred as a result of the associated tests. Data are adequate to support a closure option of no further action for these sites.

Historical evidence indicates that there is limited contamination within the potential crater area of the TRUCHAS-CHAMISAL detonation associated with CAS 03-23-29. However, levels are too low to be seen in fly-over data and do not pose a risk to workers or the environment. Data are adequate to support a closure option of closure in place with administrative controls. The site is in a stable condition and requires no additional controls; therefore, no additional closure activities will be conducted. The site is currently posted in compliance with 10 CFR 835 as a URMA. The Demarcation Project will monitor the area for continued compliance with 10 CFR 835.

Historical evidence also indicates that there may be limited contamination present at the SULKY site associated with CAS 18-23-02. However, levels are too low to be seen in fly-over data and do not pose a risk to workers or the environment. Data are adequate to support a closure option of closure in place with administrative controls. The site is in a stable condition and requires no additional controls; therefore, no additional closure activities will be conducted. The site is currently posted in compliance with 10 CFR 835 as an RMA. The Demarcation Project will monitor the area for continued compliance with 10 CFR 835. 
CAU 107 SAFER Plan

Section: Data Quality Objectives

Revision: 1

Date: March 2009

\section{THIS PAGE INTENTIONALLY LEFT BLANK}




\subsection{FIELD ACTIVITIES AND CLOSURE OBJECTIVES}

This section provides a description of and the rationale for proposed field activities for each site based on the CSM.

\subsection{Contaminants of Potential Concern}

Based on historical data and process knowledge presented in Section 2.0 of this report, there are no contaminants of potential concern at 13 of 15 CASs in CAU 107. Contaminants of potential concern are assumed to be present at CAS 03-23-29 and CAS 18-23-02. The contaminants of potential concern were identified through historical information about the sites. A post-test radiological survey identified low levels of alpha contamination on a concrete pad at CAS 03-23-29, and DOE/NV (1996) identified particulate releases of radionuclides at CAS 18-23-02.

\subsection{REMEDIATION}

Operational history and historical data indicate that there are no contaminants of concern at 13 of the 15 CASs in CAU 107. Data are adequate to support a closure option of no further action for these CASs.

CAS 03-23-29, Truchas-Chamisal Contamination Area, and CAS 18-23-02, U-18d Crater (Sulky), will be closed in place with administrative controls. The sites are currently posted in compliance with 10 CFR 835. URs will be implemented that encompass these CAS locations and UR warning signs will be posted. The URs will provide adequate administrative controls to limit site access and worker dose.

\subsection{VERIFICATION}

Verification samples are not required for the closure of CAU 107.

\subsection{Closure}

Additional remediation activities are not required for closure of any of the sites in CAU 107. URs will be implemented that encompass the CAS locations for CAS 03-23-29 and CAS 18-23-02, and UR warning signs will be posted. The URs will provide adequate administrative controls to limit site access and worker dose.

\subsection{DURATION}

Closure activities, including verification of existing postings, is expected to take no more than 30 calendar days. 
CAU 107 SAFER Plan

Section: Field Activities

Revision: 1

Date: March 2009

\section{THIS PAGE INTENTIONALLY LEFT BLANK}




\subsection{REPORTS AND RECORDS AVAILABILITY}

This document is available in the DOE public reading rooms located in Las Vegas and Carson City, Nevada, or by contacting the appropriate DOE Project Manager. The Nevada Division of Environmental Protection maintains the official Administrative Record for all activities conducted under the auspices of the FFACO. 
CAU 107 SAFER Plan

Section: Reports \& Records

Revision: 1

Date: March 2009

\section{THIS PAGE INTENTIONALLY LEFT BLANK}




\subsection{INVESTIGATION/REMEDIATION WASTE MANAGEMENT}

This project is not expected to generate any investigation or remediation waste. 
CAU 107 SAFER Plan

Section: Investigation/Remediation

Revision: 1

Date: March 2009

\section{THIS PAGE INTENTIONALLY LEFT BLANK}


Revision: 1

Date: March 2009

\subsection{QUALITY ASSURANCE/QUALITY CONTROL}

Samples will not be collected for closure of CAU 107; therefore, a QA/QC plan is not applicable. 
CAU 107 SAFER Plan

Section: QA/QC

Revision: 1

Date: March 2009

\section{THIS PAGE INTENTIONALLY LEFT BLANK}




\subsection{REFERENCES}

AEC, see U.S. Atomic Energy Commission.

Anspaugh, L. R., and J. I. Daniels, 1995. Development of the Scientific Basis for Establishing the Boundary Conditions Between "Unrestricted Use" and "Posting" for Exposure Due to Residual Radioactive Contamination of Soil at the Nevada Test Site. Lawrence Livermore National Laboratory. UCRL-JC-119936. Livermore, CA.

Bechtel Nevada, 1999. An Aerial Radiological Survey of the Nevada Test Site, DOE/NV/11718--324. Prepared for the U.S. Department of Energy, Nevada Operations Office. Las Vegas, NV.

Bechtel Nevada, 2000. Nevada Test Site Contaminated Land Areas Report, Volume I. DOE/NV/11718--481-VOL 1. Prepared for U.S. Department of Energy. Las Vegas, NV.

BN, see Bechtel Nevada.

CFR, see Code of Federal Regulations.

Code of Federal Regulations, Title 10, Part 835, “Occupational Radiation Protection,” 1993.

Defense Nuclear Agency, 1981. Shots ESS Through MET and Shot Zucchini, The Final TEAPOT Tests. Prepared for the U.S. Department of Defense. Las Vegas, NV.

Defense Nuclear Agency, 1982. Safety Experiments November 1955 - March 1958. Prepared for the U.S. Department of Defense. Las Vegas, NV.

Desert Research Institute, 2007. Radionuclide Inventory and Distribution Program (RIDP) Database, Rev. 2. April. Prepared by K. J. Gray, D. S. Shafer, K. Self, C. Martin, and R. McArthur. Las Vegas, NV.

DNA, see Defense Nuclear Agency.

DoD, see U.S. Department of Defense.

DOE, see U.S. Department of Energy.

DOE/NV, see U.S. Department of Energy, Nevada Operations Office.

DRI, see Desert Research Institute.

EPA, see U.S. Environmental Protection Agency.

FFACO, see Federal Facility Agreement and Consent Order.

Federal Facility Agreement and Consent Order, 1996 (as amended February 2008). Agreed to by the State of Nevada; U.S. Department of Energy, Environmental Management; U.S. Department of Defense; and U.S. Department of Energy, Legacy Management.

Hendricks, T. J., and S. R. Riedhauser, 1999. An Aerial Radiological Survey of the Nevada Test Site. DOE/NV/11718--324. Prepared by Bechtel Nevada for the U.S. Department of Energy. Las Vegas, NV.

Johnston, J., 2007. Stoller-Navarro Joint Venture (SNJV), Electronic Correspondence to E. Stickney (SNJV) regarding the reason for posting of Underground Radioactive Material Area by original Demarcation personnel, August 27, 2007. Las Vegas, NV. 


\subsection{REFERENCES (continued)}

Kathren, R. L., 1984. Radioactivity in the Environment Sources, Distribution and Surveillance. Richland, WA.

Lawrence Livermore National Laboratory, 1970. Written Communication. Unclassified Internal Memorandum from C. Meier and J. Cramer to D. Simms. Subject: "FLASK-RED Cable Pull, U2az3." April 8, 1970.

LLNL, see Lawrence Livermore National Laboratory.

Los Alamos National Laboratory, 1951. Operation Ranger, Nevada Test Site, Jan-Feb 1951, Volume 4, Program Reports-Gross Weapons Measurements. WT-201.

McArthur, R. D., and J. F. Kordas, 1983. Nevada Test Site Radionuclide Inventory and Distribution Program: The Galileo Area. DOE/NV/10162--14. Prepared by Desert Research Institute. Las Vegas, NV.

McArthur, R. D., and J. F. Kordas, 1985. Nevada Test Site Radionuclide Inventory and Distribution Program: Report \#2, Areas 2 and 4. DOE/NV/10162--20. Prepared by Desert Research Institute. Las Vegas, NV.

McArthur, R. D., and S. W. Mead, 1987. Nevada Test Site Radionuclide Inventory and Distribution Program: Report \#3, Areas 3, 7, 8, 9, and 10. DOE/NV/10384--15. Prepared by Desert Research Institute. Las Vegas, NV.

McArthur, R. D., and S. W. Mead, 1988. Nevada Test Site Radionuclide Inventory and Distribution Program: Report \#4, Areas 18 and 20. DOE/NV/10384--22. Prepared by Desert Research Institute. Las Vegas, NV.

McArthur, R. D., and S. W. Mead, 1989. Nevada Test Site Radionuclide Inventory and Distribution Program: Report \#5, Areas 5, 11, 12, 15, 17, 18, 19, 25, 26, and 30. DOE/NV/10384--26. Prepared by Desert Research Institute. Las Vegas, NV.

McArthur, R. D., 1991. Radionuclides in Surface Soil at the Nevada Test Site. DOE/NV/10845--02. Prepared by Desert Research Institute. Las Vegas, NV.

Murphy, T., 2004. Nevada Division of Environmental Protection Letter to R. M. Bangerter, Jr. (NNSA/NSO). Review of Industrial Sites Project Document Guidance for Calculating Industrial Sites Project Remediation Goals for Radionuclides in Soil Using the Residual Radiation (RESRAD) Computer Code. November 19, 2004. Las Vegas, NV.

National Council on Radiation Protection, 1999. Recommended Screening Limits for Contaminated Surface Soil and Review of Factors Relevant to Site-Specific Studies. NCRP Report No. 129. Washington, D.C.

NCRP, see National Council on Radiation Protection and Measurements.

NNSA/NSO, see U.S. Department of Energy, National Nuclear Security Administration Nevada Site Office.

NNSA/NV, see U.S. Department of Energy, National Nuclear Security Administration Nevada Operations Office. 


\subsection{REFERENCES (continued)}

Nuclear Data Center, Japan Atomic Energy Agency (JAEA), 2006. WWW Chart of Nuclides 2004. Available at: http://wwwndc.tokai-sc.jaea.go.jp/CN04/. Last modified:

February 21, 2006.

Proctor, A. E., 1997. Aerial Radiological Surveys. Bechtel Nevada. DOE/NV/11718--127. Las Vegas, NV.

Raytheon Services Nevada, 1991. Written Communication. Nevada Test Site Drilling and Mining Summary. Prepared for the U.S. Department of Energy, Nevada Operations Office. Las Vegas, NV.

REECo, see Reynolds Electrical and Engineering Company, Inc.

Reynolds Electrical and Engineering Company, Inc., 1957. Plumbbob On-Site Rad-Safety Report. OTO-57-2. Las Vegas, NV.

Reynolds Electrical and Engineering Company, Inc., 1972. Health Data Report - Truchas Event, 305786. Las Vegas, NV.

Reynolds Electrical and Engineering Company, Inc., 1973a. Onsite Radiological Safety Report (for Events Not Publicly Announced) Operation Nougat through Operation Emery July 1961-June 1971, CIC310748/DOE/NV. Las Vegas, NV.

Reynolds Electrical and Engineering Company, Inc., 1973b. Operation Grommet Onsite Radiological Safety Report (for Events Not Publicly Announced) July, 1971, through June, 1972, NVC-410-19. Las Vegas, NV.

Reynolds Electrical and Engineering Company, Inc., 1991. Nevada Test Site Inventory of Inactive and Abandoned Facilities and Waste Sites, Areas 1-4, Volume 1 of 5. DOE/NV/10630--18. Las Vegas, NV.

Reynolds Electrical and Engineering Company, Inc., 1995. Site Demarcation Survey. Prepared for the U.S. Department of Energy, Nevada Operations Office. Las Vegas, NV.

RSN, see Raytheon Services Nevada.

Spriggs, G. D., 2007. “Fallout Regimes.” UCRL-POST-219627. Lawrence Livermore National Laboratory. Livermore, CA. Official Use Only.

U.S. Atomic Energy Commission, 1953. Operation Upshot Knothole, Nevada Proving Ground, March-June 1953, Radiological Safety Operations. WT-702.

U.S. Department of Defense, 1982. Operation Ranger: Shots ABLE, BAKER, EASY, BAKER-2, FOX, 25 January-6 February, 1951. DNA 6022F. Prepared by the Defense Nuclear Agency.

U.S. Department of Energy, 1993. Openness Press Conference Fact Sheets. Available at: https://www.osti.gov/opennet/reports/dec71993.pdf. [Accessed April 7, 2008]

U.S. Department of Energy, 2000. Origins of the Nevada Test Site. DOE/MA-0518. Washington, D.C. 


\subsection{REFERENCES (continued)}

U.S. Department of Energy, National Nuclear Security Administration Nevada Operations Office, 2002. Corrective Action Investigation Plan for Corrective Action Unit 204: Storage Bunkers, Nevada Test Site, Nevada. DOE/NV--866. Las Vegas, NV.

U.S. Department of Energy, National Nuclear Security Administration Nevada Site Office, 2004a. Corrective Action Decision Document for Corrective Action Unit 204: Storage Bunkers, Nevada Test Site, Nevada. DOE/NV--959. Las Vegas, NV.

U.S. Department of Energy, National Nuclear Security Administration Nevada Site Office, 2004b. NV/YMP RadCon Manual. DOE/NV/11718--079 REV 5. Las Vegas, NV.

U.S. Department of Energy, National Nuclear Security Administration Nevada Site Office, 2005. An Aerial Radiological Survey of the Area Surrounding and Encompassing the Rocky Flats Environmental Technology Site. DOE/NV/11718--1153. Jefferson County, CO.

U.S. Department of Energy, National Nuclear Security Administration Nevada Site Office, 2006a. Closure Report for Corrective Action Unit 204: Storage Bunkers, Nevada Test Site, Nevada. DOE/NV--1117. Las Vegas, NV.

U.S. Department of Energy, National Nuclear Security Administration Nevada Site Office, 2006b. Industrial Sites Project Establishment of Final Action Levels. DOE/NV--1107. Las Vegas, NV.

U.S. Department of Energy, National Nuclear Security Administration Nevada Site Office, 2007b. Corrective Action Decision Document/Closure Report for Corrective Action Unit 542: Disposal Holes, Nevada Test Site, Nevada. DOE/NV--1196. Las Vegas, NV.

U.S. Department of Energy, Nevada Operations Office, 1996. Radiological Effluents Released from U.S. Continental Tests, 1961 through 1992. Prepared by Bechtel Nevada. Las Vegas, NV.

U.S. Department of Energy, Nevada Operations Office, 1997. Plowshare Program Executive Summary.

U.S. Department of Energy, Nevada Operations Office, 2000. United States Nuclear Tests, July 1945 through September 1992. DOE/NV/-209-Rev 15. Las Vegas, NV.

U.S. Environmental Protection Agency, 2006. Guidance on Systematic Planning Using the Data Quality Objectives Process. EPA QA/G-4. Washington, D.C.

Videon, F. F., 1965. Crater Measurements: Project Sulky. U.S. Army Corps of Engineers Report PNE-713F. 
CAU 107 SAFER Plan

Section: Appendix A

Revision: 1

Date: March 2009

\section{APPENDIX A. PROJECT ORGANIZATION}


CAU 107 SAFER Plan

Section: Appendix A

Revision: 1

Date: March 2009

THIS PAGE INTENTIONALLY LEFT BLANK 


\section{PROJECT ORGANIZATION}

The U.S. Department of Energy, National Nuclear Security Administration Nevada Site Office (NNSA/NSO) Acting Federal Sub-Project Director is Kevin Cabble, and his telephone number is (702) 295-5000.

The identification of the project Health and Safety Officer and the Quality Assurance Officer can be found in the appropriate plan. However, personnel are subject to change, and it is suggested that the appropriate DOE Project Manager be contacted for further information. The Task Manager will be identified in the Federal Facility Agreement and Consent Order Monthly Activity Report prior to the start of field activities. 
CAU 107 SAFER Plan

Section: Appendix A

Revision: 1

Date: March 2009

THIS PAGE INTENTIONALLY LEFT BLANK 


\section{APPENDIX B. NEVADA DIVISION OF ENVIRONMENTAL PROTECTION COMMENT RESPONSE FORM}


CAU 107 SAFER Plan

Section: Appendix B

Revision: 1

Date: March 2009

THIS PAGE INTENTIONALLY LEFT BLANK 


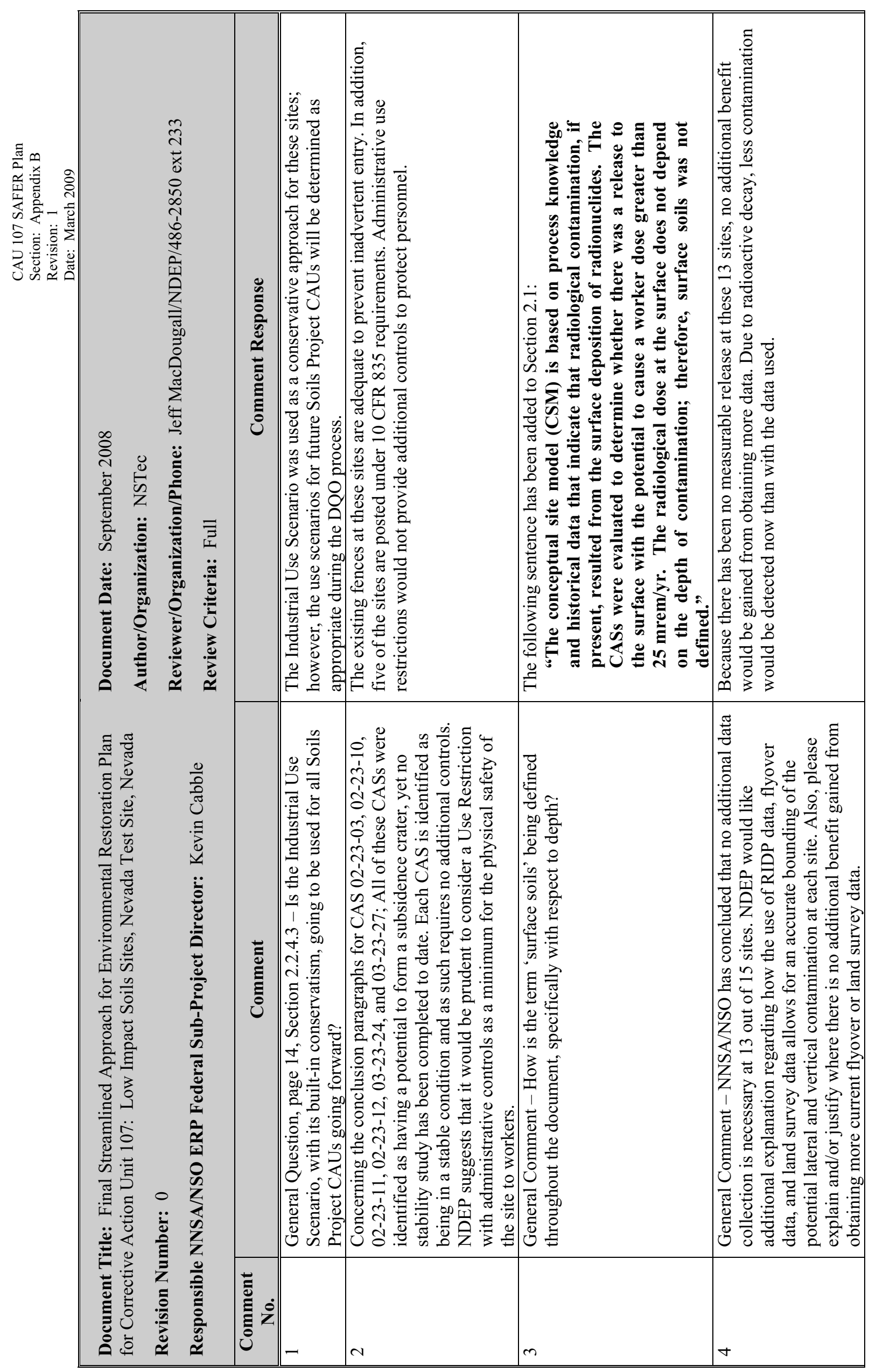




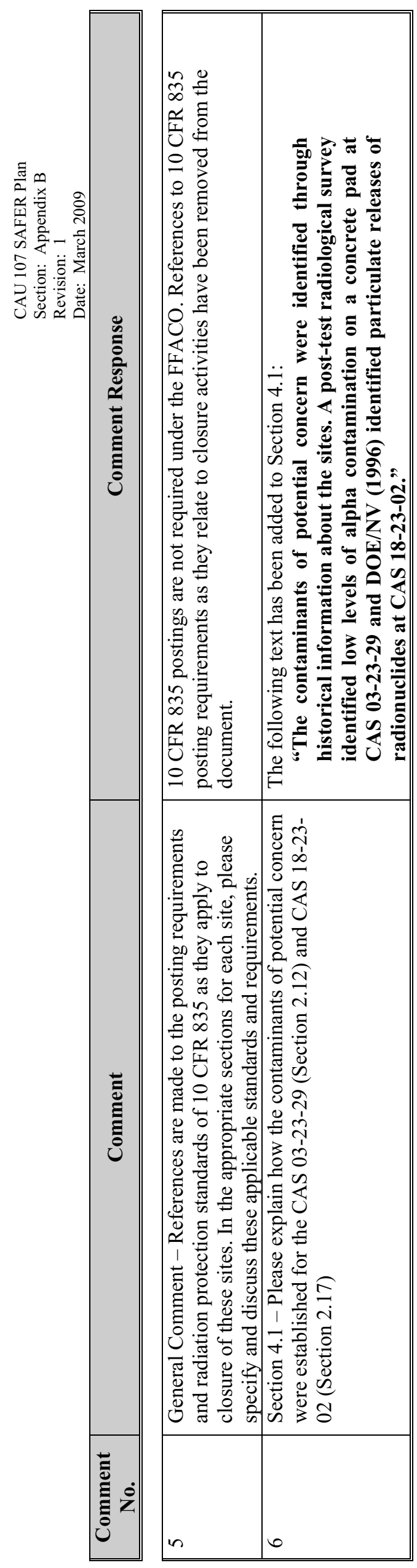




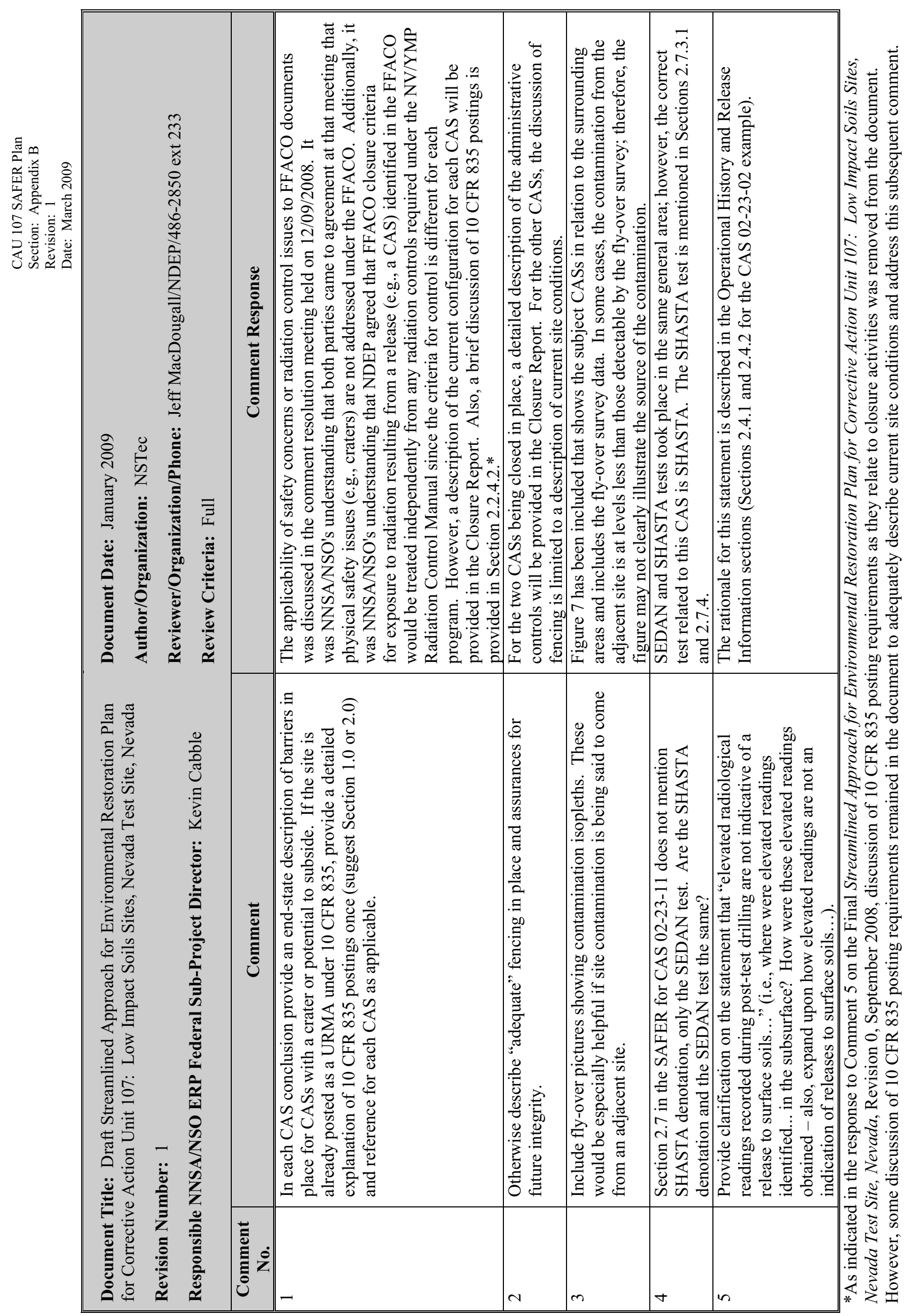


CAU 107 SAFER Plan

Section: Appendix B

Revision: 1

Date: March 2009

THIS PAGE INTENTIONALLY LEFT BLANK 
CAU 107 SAFER Plan

Section: Distribution List

Revision: 1

Date: March 2009

\section{LIBRARY DISTRIBUTION LIST}


CAU 107 SAFER Plan

Section: Distribution List

Revision: 1

Date: March 2009

\section{THIS PAGE INTENTIONALLY LEFT BLANK}




\section{LIBRARY DISTRIBUTION LIST}

U.S. Department of Energy

1 (Uncontrolled, electronic copy)

National Nuclear Security Administration

Nevada Site Office

Technical Library

P.O. Box 98518, M/S 505

Las Vegas, NV 89193-8518

U.S. Department of Energy

1 (Uncontrolled, electronic copy)

Office of Scientific and Technical Information

P.O. Box 62

Oak Ridge, TN 37831-0062

Southern Nevada Public Reading Facility

2 (Uncontrolled, electronic copies)

c/o Nuclear Testing Archive

P.O. Box 98521, M/S 400

Las Vegas, NV 89193-8521

Manager, Northern Nevada FFACO

1 (Uncontrolled, electronic copy)

Public Reading Facility

c/o Nevada State Library \& Archives

Carson City, NV 89701-4285 
CAU 107 SAFER Plan

Section: Distribution List

Revision: 1

Date: March 2009

\section{THIS PAGE INTENTIONALLY LEFT BLANK}

